\title{
Community as a Sociological Category - Basing on the Study of a Religious Community
}

\author{
Andrzej Borowski \\ Department of Sociology and Social Works, Faculty of Education and Philosophy, \\ Pomeranian University in Słupsk, 64 Westerplatte St., 76-200 Słupsk, Poland \\ E-mail address: aubor@poczta.onet.pl
}

\begin{abstract}
Communities exert great influence on their members. Staying in a given community leaves an indelible mark on every personality. Obviously, it is not true that a human being is entirely determined by its community as to a certain degree that person can choose between various environments and communities. The community type depends on mutual interpersonal relations. Creating the community (especially among young people) is not easy although many people dream of that. People oscillate between the suffering of loneliness and the fear of dependence. The former makes them seek a place of an absolute union with other people sharing the same approach. The latter leads to suffering in being together, in experiencing the self as unable to communicate, to the inability to put up with mutual commitment, as this is felt as manipulating their freedom and autonomy. Some people wish to live in mutual closeness but they do not know how to motivate that desire. Every community should create their idea of life specifying why its members decided to be together and what the expectations towards one another are. This means that the community should have a shorter or longer period of time before establishment for preparing for common life and determining its goals. The community as a sociological or religious category still remains an incomparable example of a perfect social structure with a multiple reach. Participation therein, based on the principles of accountability, voluntariness and love, leading to a permanent conversion and internalization of the suggested attitudes, as well as the postulated need to participate in and serve (ministry) the community is an efficient antidote for the spiritual torpor of the today's world. The work includes a wide range of general and specific roles within a community as a sociological and religious category.
\end{abstract}

Keywords: community; religious movement; post-conciliar church revival; service; social structure

\section{Reviewers}

Prof. Janusz Mariański

Prof. Wojciech Świątkiewicz 


\title{
Wspólnota jako Kategoria Socjologiczna - na Przykładzie Studium Wspólnoty Religijnej
}

\author{
Andrzej Borowski \\ Katedra Socjologii i Pracy Socjalnej, Wydział Edukacyjno-Filozoficzny, \\ Akademia Pomorska w Słupsku, ul. Westerplatte 64, 76-200 Słupsk, Poland \\ E-mail address: aubor@poczta.onet.pl
}

\section{STRESZCZENIE}

Wspólnoty wywierają wielki wpływ na swoich członków. Fakt pobytu w danej wspólnocie wywiera na każdej osobowości niezatarte piętno. Oczywiście nie jest prawdą, że człowiek jest całkowicie zdeterminowany przez swoją wspólnotę, ponieważ do pewnego stopnia ma możliwość wyboru pomiędzy różnymi środowiskami i wspólnotami. Rodzaj wspólnoty zależy od wzajemnych oddziaływań międzyludzkich. Tworzenie wspólnoty (zwłaszcza wśród osób młodych) nie jest sprawą łatwą, mimo iż wiele osób tego pragnie. Ludzie oscylują między udręką samotności i obawą zależności. Ta pierwsza prowadzi ich do poszukiwania miejsca całkowitego połączenia z innymi osobami podobnie myślącymi. Druga prowadzi do doświadczenia cierpienia w byciu razem, w odczuwaniu siebie, jako niezdolnych do komunikacji, do nietolerowania wzajemnego zaangażowania, ponieważ wydaje się to manipulacją ich wolności i autonomii. Niektórzy ludzie chcą żyć we wzajemnej bliskości, ale nie bardzo wiedzą, czym to pragnienie umotywować. Każda wspólnota powinna stworzyć własny pomysł na życie, który określałby, dlaczego jej członkowie zdecydowali się być razem i jakie są ich oczekiwania w stosunku do każdego. Oznacza to, że wspólnota zanim powstanie powinna dysponować krótszym, lub dłuższym okresem czasu na przygotowanie wspólnego życia i określenia swoich celów. Wspólnota jako kategoria socjologiczna czy religijna pozostaje nadal niezastąpionym wzorem doskonałej struktury społecznej, o wielorakim zasięgu. Uczestnictwo w niej oparte na zasadach odpowiedzialności, dobrowolności i miłości, prowadzące do trwałej konwersji i internalizacji proponowanych postaw, postulowana konieczność uczestnictwa oraz diakonii (służby) we wspólnocie i na jej rzecz, jest skutecznym antidotum na marazm duchowy dzisiejszego świata.

Poniższa praca zawiera cały zakres ról ogólnych i szczegółowych członów wspólnoty jako kategorii socjologicznej o religijnej.

Stowa kluczowe: wspólnota; ruch religijny; posoborowa odnowa kościoła; służba; struktura społeczna

\section{Recenzenci}

Ks. Prof. dr hab. Janusz Mariański

Prof. dr hab. Wojciech Świątkiewicz 
Spis Treści:

$-3$

Wstęp

$-5$

1. Zarys teoretyczny problematyki badań

$-6$

1.1. Makro i makrosocjologia

$-6$

1.2. Między mikro i makrosocjologią

$-10$

1.3. Emergencja zjawisk społecznych

$-12$

1.4. Struktury dalekiego i bliskiego zasięgu

$-13$

1.5. Socjologia wartości

$-15$

1.6. Socjologia religii

$-16$

1.7. Elitaryzm

$-22$

2. Wspólnota jako kategoria socjologiczna i religijna

- 27

2.1 Wspólnota jako kategoria socjologiczna

$-27$

2.1.1 Wspólnota według Toenniesa

$-27$

2.1.2. Inne ujęcia wspólnoty

$-29$

2.1.3. Typologia wspólnot

$-32$

2.1.4. Elementy konstytutywne wspólnot

$-34$

2.1.5. Internalizacja $\mathrm{w}$ procesie budowy wspólnoty

$-35$

2.1.6. Wartości a zachowanie członków wspólnoty

$-36$

2.1.7. Autorytet i prestiż we wspólnocie

$-37$

2.2. Wspólnota jako kategoria religijna

$-39$

2.2.1. Wspólnota religijna w ujęciu "communio"

$-39$

2.2.2. Wspólnota religijna jako kategoria socjologiczna

$-45$

2.2.3. Rodzaje wspólnot religijnych

$-50$

2.2.4. Elementy konieczne do powstania wspólnoty religijnej $\quad-54$

2.2.5. Konwersja

$-59$

2.2.6. Ruchy religijne jako wypełnienie luki między mikro i makrosocjologią

$-62$

3. Pojęcia pokrewne kategorii wspólnota

$-78$

3.1. Więź społeczna

$-78$

3.2. Integracja społeczna

$-80$

3.3. Solidarność społeczna

$-83$ 
3.4. Jedność

$-85$

3.5. Consensus

3.6. Społeczność (community)

3.7. Spójność społeczna

4. Metody i techniki postępowania badawczego

5. Badania szczegółowe wspólnoty jako kategorii socjologicznej i religijnej

5.1. Charakterystyka badanej wspólnoty

5.2. Weryfikacja przyjętych hipotez badawczych

6. Podsumowanie wyników badań. Wnioski

7. Bibliografia
$-107$

$-86$

- 88

- 91

- 97

- 107

$-112$

- 145

$-156$ 


\section{WSTĘP}

W sytuacji załamania się ludzkiej nadziei, optymizmu i wiary $\mathrm{w}$ lepsze jutro, w sytuacjach stresowych łatwo rodzą się zachowania patologiczne, lub szukanie sensu życia i oparcia w jakimś systemie wartości. Aktualna sytuacja naszego kraju, z uwagi na brak autorytetów i wzorców życia społecznego (skutecznie podważanych od paru lat), generuje powstawanie różnych dewiacji i zachowań, sprzecznych z szeroko rozumianym dobrem społecznym. W tej pracy chcę przedstawić koncepcję wspólnoty, (doskonałej grupy społecznej), która może być osiągalna dla każdego.

Przemiany religijności nie przebiegają w oderwaniu od zjawisk społeczno kulturowych, lecz są częścią składową ogólnych przeobrażeń społeczeństwa polskiego i jego subsystemów społecznych. Budowanie wspólnoty na gruncie społecznym jak i religijnym objawia się w relacjach interpersonalnych. Istnienie i rozwój wspólnot

będących przedmiotem i podmiotem określonych działań jest miarą społeczeństwa.

Jak uczy socjologia, przewroty społeczne powodują zamieszanie, zanik moralności, marazm. W ludziach następuje dezorientacja i zamęt, nie widzą w którą stronę iść, są niepewni, co do wartości rzeczy, które kiedyś wydawały im się niezaprzeczalnie ważne.

Społeczeństwo dnia dzisiejszego potrzebuje nie programów, lecz doświadczenia wspólnoty, gdy spoglądamy na podstawowe problemy leżące w dziedzinie dowolnej organizacji społecznej, i w tzw. dynamice środowiska, należy zasygnalizować pewne priorytety:

- środowiska i wspólnoty są ważniejsze niż instytucje w życiu społecznym,

- przywództwo wyłaniające się w sposób naturalny jest tym typem kierownictwa, które w chwili obecnej jest najbardziej pożądane,

- ruchy społeczne nie są przeszkodą ale czymś istotnym dla przetrwania społeczeństwa i powinny być popierane.

Wspólnota jest rodzajem środowiska, jego silną efektywną formą. Aby wspólnota mogła zaistnieć potrzebna jest przemiana wewnętrzna (konwersja) i znalezienie odpowiedniej liczby konwertytów.

Niniejsza praca stanowi podsumowanie kilkuletnich badań metodą obserwacji uczestniczącej, we wspólnocie Ruchu "Światło - Życie", w rzeczywistości małomiasteczkowej parafii. Za okazaną pomoc, zwłaszcza w kwestii metodologicznej, pragnę złożyć serdeczne podziękowania Panu Profesorowi dr hab. Adamowi Sosnowskiemu promotorowi pracy.

\section{Przypisy}

1. F. Toennies - Wspólnota i stowarzyszenie - Warszawa 1988, str. 25-49.

2. S. B. Clark - Budowanie wspólnot chrześcijańskich - Wrocław 1994, str. 7-10,

3. J. Mariański - Religijność w procesie przemian - Warszawa 1991, str. 5. 


\section{ZARYS TEORETYCZNY PROBLEMATYKI BADAŃ}

\section{1. Makro i mikrosocjologia}

Wszystkie funkcjonujące na terenie socjologii dyscypliny szczegółowe, takie jak np. socjologia przemysłu, socjologia wsi, socjologia miasta, socjologia wychowania, socjologia religii ograniczają swe pole badawcze do obszaru analiz socjologicznych, tzn. stosują tak zwany socjologiczny punkt widzenia. Zupełnie inne kryterium przyjmuje się wówczas, gdy w grę wchodzi wyodrębnienie takiej subdyscypliny socjologicznej, jaką jest np. mikrosocjologia, czy makrosocjologia. Odrębność mikrosocjologii nie wynika z faktu, że jej obszar badawczy dotyczy pewnej specyficznej sfery działalności lub pewnych specyficznych instytucji społecznych i grup społecznych, lecz z tego, iż jej dziedziną badawczą jest jakościowo odrębny, emergentny poziom integracji zjawisk społecznych, poziom struktury świata społecznego, poziom mikrostruktur społecznych.

Stosunek mikrosocjologii do makrosocjologii ma konfliktowy charakter. Socjologia nie może równocześnie zawierać w sobie obu typów analiz, bowiem są one całkowicie wobec siebie rozłączne, jak i rozciągające się na cały obszar analiz socjologicznych. Niewątpliwie tradycja Durkheimowska może być egzemplifikacją takiego stosunku do socjologii. Przy tym zakłada podobny stosunek do zasadniczych cech świata społecznego. Mikrosocjologia w takim ujęciu pozostaje dziedziną socjologii, której przedmiotem są działania indywidualne. Tymczasem pogląd taki jest dość słabo uzasadniony na gruncie ontologii (1).

Model taki zakładałby bowiem taki model ontologiczny rzeczywistości społecznej, w którym zasadnicza linia demarkacyjna pomiędzy obiektem badania makrosocjologii i mikrosocjologii przebiegałaby na granicy działań indywidualnych $\mathrm{z}$ jednej strony i wszelkich struktur ponadindywidualnych $\mathrm{z}$ drugiej. Wynikałoby więc stąd, że nie istnieją jakieś istotniejsze różnice $\mathrm{w}$ obrębie samych ponadjednostkowych struktur lub też, że wszelkie istniejące różnice nie osiągają tego stopnia istotności, co odmienność działań jednostkowych od struktur ponadjednostkowych. Między innymi marksizm jest koncepcją zakładającą konkurencyjność mikrosocjologii i makrosocjologii, zaś rozstrzygnięcie, jakie przyjmuje, to zdecydowana opcja na rzecz makrosocjologizmu. To co jest według marksistów esencją społeczeństwa, to makrostruktury społeczne (2). Zatem poziom mikrostruktur jest nieprawomocnym obiektem analiz socjologicznych.

W podobnym kierunku szły rozważania charakterystyczne dla teorii społeczeństwa $\mathrm{M}$. Webera, H. Spencera i V. Pareto (3). Opozycyjną do makrosocjologizmu koncepcją wzajemnych relacji mikrostruktur i makrostruktur społecznych jest tzw. mikrosocjologizm. Według tej teorii socjologia nie jest niczym innym, jak jedynie badaniem mikroprocesów oraz, że zrozumienie poziomu mikrozjawisk społecznych wystarcza, by wyjaśnianie jakie się tutaj formułuje generować na wszystkie zjawiska społeczne, włączając funkcjonowanie całych społeczeństw.

Stanowisko powyższe zdominowało w latach 50-tych i późniejszych socjologię amerykańską. By uprawomocnić taki pogląd, G. Homans zakłada, żeby wyjaśnić jakiekolwiek twierdzenie z dziedziny socjologii, należy je zredukować, tzn. wyprowadzić z praw psychologii behawioralnej (4). Staje w ten sposób na jeszcze bardziej radykalnym stanowisku, gdyż utrzymuje, że zrozumienie świata, społecznego to nie tylko rozumienie małych struktur, ile wręcz działań i zachowań jednostek ludzkich. Analiza makrosocjologiczna jest dla Homansa rodzajem reifikacji gdyż struktura społeczna nie może być badana jako pewna abstrakcja w stosunku do jednostek ludzkich tworzących społeczeństwo. W rezultacie pogląd, którego zwolennikiem jest Homans, a który stanowi 
znakomitą egzemplifikację mikrosocjologizmu daje się streścić następująco. Z punktu widzenia prawidłowego rozpoznania rzeczywistości istotne są procesy i przedmioty wytworzone w toku interakcji jednostek ludzkich w małych grupach, jak kooperacja, konformizm, dewiacja, status, przywództwo, władza.

Podobną argumentację można znaleźć w pracach współczesnych interakcjonistów. Świat społeczny jest światem ludzkich interakcji, działań i ludzkich wyobrażeń. Jest to w istocie świat ludzkich interpretacji społecznej rzeczywistości, przez co jest niezwykle zmienny i nie można sobie wyobrazić, by mogła w nim uczestniczyć jakaś większa, bardziej stabilna struktura społeczna. Do przedstawicieli tego kierunku niewątpliwie zaliczyć można H. Blumera i M. Kuhna (5). Wcześniejsze teorie socjologiczne zawierają zbliżone poglądy na rzeczywistość społeczną (G. Simmel) (6).

Funkcjonalizm dał inną odpowiedź na pytanie, o wzajemne relacje między poziomem mikrostruktur społecznych i mikrosocjologią, a poziomem makrostruktur społecznych i makrosocjologią. Przyjął mianowicie perspektywę, którą określić można jako inkluzywną istnieje możliwość rozwijania maksymalnie pojemnego schematu o uniwersalnej stosowalności, który mógłby być użyty do interpretacji zjawisk społecznych na wszystkich poziomach analizy. W przekonaniu funkcjonalistów istnieje szansa na zbudowanie takiego schematu, w którym w sposób współuprawniony i niesprzeczny wzajemnie współegzystowałyby obok siebie mikrosocjologia i makrosocjologia. D. Martindale wysuwa tezę o istnieniu dwóch odłamów we współczesnym funkcjonalizmie. Ten pierwszy miałby się wiązać głównie z pracami R. Balesa i P. Slatera (7), podejmujących problem różnicowania się ról społecznych $\mathrm{w}$ małych grupach, na bazie którego wypracowują oni ogólniejszy mikrofunkcjonalny schemat działania małej grupy. Jest to oczywiście egzemplifikacja prac należących do nurtu mikrofunkcjonalistycznego. Drugi odłam to $\mathrm{m}$. in. funkcjonalny imperatywizm T. Parsonsa (8).

Myśl o współczesnej współegzystencji wyraził Parsons mówiąc o makrosocjologii i mikrosocjologii, że teoria działania, włączając jej odgałęzienie socjologiczne jest stosowalna zarówno do działań szczebla mikro jak i makroskopowego. Teoria działania, jest teorią wyjaśniającą procesy zachodzące zarówno w małych grupach, jak i w złożonych społeczeństwach. Jednakże, pomimo tak wyrażonych zapewnień, sam Parsons nie wypracował dostatecznie przekonujących narzędzi analitycznych, możliwych do interpretacji struktury i działania mikrostruktur społecznych. Podobnie jak jego ówcześni współpracownicy R. Bales, czy P. Slater nie usiłował wyraźnie określić, na czym miałby polegać związek między wewnętrznym zróżnicowaniem ról w małych grupach, a strukturą wielkich systemów społecznych. Zarówno Parsons, jak i wspomniani jego uczniowie mieli świadomość istotnych różnic strukturalnych mikrostruktur i makrostruktur, co odbiło się wyraźnie $\mathrm{w}$ ich rozwiązaniach teoretycznych. Nie zatroszczyli się o to, by podjąc próbę wykazania, na czym polegają te różnice (emergencja własności) i jak daleko one sięgają. Perspektywa inkluzywna dostarczyła wielu argumentów zarówno teoretycznych jak i ontologicznych, na rzecz tezy o istnieniu odrębnych poziomów integracji świata społecznego, poziomu mikrostruktur i makrostruktur, a pośrednio też argumentów pozwalających podjąć problem stosunku mikrosocjologii do makrosocjologii, jednakże nie dała wystarczającej odpowiedzi na pytanie o rodzaj tych powiązań.

Podstawowa konkluzja do jakiej dochodzą reprezentujący poprzednie podejścia do problemu mikrosocjologii i makrosocjologii jest zawarta $\mathrm{w}$ tezie, że $\mathrm{w}$ świecie istnieją odrębne typy strukturyzowane mikro i makrostrukturami (9).

Pojęcie struktury społecznej jest wieloznaczne i zmienia się historycznie. Różnie jest ono rozumiane przez przedstawicieli nauk społecznych. Współczesny nurt myślowy zwany 
strukturalizmem jest wielce złożoną propozycją metodologiczną, opartą na niejednoznacznych założeniach teoretycznych. Biorąc pod uwagę system relacji struktury społecznej i układ elementów, mówi się o strukturze funkcjonalnej, sensownej czy też dynamicznej. Zawartość mnogości elementów w strukturach, które rozpatrywane są jako określone całości rzędu niższego (mikrostruktury), pośredniego (mezostruktury) i wyższego (makrostruktury), nie wyklucza ich rozwoju, czy też przechodzenia jednych w drugie. Oznacza to, iż każdy opis struktury obiektu społecznego bądź jego elementów, a także związków i określonych stosunków występujących w jego układzie posiada względny charakter (10). Punktem wyjścia ich podziału obok innych elementów, jest zwykle kryterium wielkości, więzi i styczności społecznych (11).

Mikrostruktury społeczne zlokalizowane są w mikroobiektach społecznych. Do nich zaliczyć można jednostki, ich wzory i role społeczne, system aktywności, czy też formę świadomości, a także małe grupy społeczne: pierwotne i wtórne, nieformalne i formalne, kliki, gangi itp. Aby je poznać, należy w procesie badawczym wyodrębnić mikroobiekty społeczne, ich procesy i formy urzeczywistniania się, poziomy i stopnie aktualizacji oraz postacie przejawiania się, funkcjonowania i rozwoju tudzież przekształcania się. Mikrostruktury społeczne wykazują szczególną podatność na zmiany społeczne (pozorne i pożądane). Ich uchwytność i rozumienia dla badacza i badanych są podstawą konfrontacji teorii z praktyką, rejestracji różnic i wspólnych płaszczyzn działania, odkrywania swoistego przejawiania postaw i zachowań społecznych. Rzadziej, zarówno u badaczy, jak i badanych, występuje proces bezpośredniego, celowego i dłuższego okresu kształtowania ról społecznych pożądanych i propagowanych postaw oraz wzorców osobowych i to zarówno jednostek, jak i grup społecznych. Stąd też oprócz innych metod i technik badawczych, badania aktywizujące stanowią istotny element realizacji wspomnianych zadań w strukturach społecznych. Liczne badania wykazują, że im bardziej struktury społeczne są spójne, tym wyższa efektywność i dynamika systemu, w którym się one znajdują (12).

Metodologiczną podstawą badań aktywizujących mikrostruktury społeczne jest analiza całokształtu komponentów warunkujących ich rozwój i trwanie oraz przekształcanie. Mikrostruktury zlokalizowane w mikrospołeczności odzwierciedlają warunki bytu indywidualnego jednostek i małych grup społecznych, ukazują role społeczne i sposoby przejawiania się postaw moralnych, zawodowych, a także procesy społeczno - wychowawcze i inne sfery aktywności ludzkiej.

Drogą systematycznych badań socjologia mikrostruktur może m. in. wyodrębnić i opisać dalsze płaszczyzny i poziomy mikrospołeczności i ich struktur, uwzględniając przy tym cechy, czy też właściwości ogólne mikroobiektów społecznych, cechy specyficzne wyodrębnione z ogółu zjawisk społecznych, cechy indywidualne typowe dla danej struktury, czy też badanego obiektu (13).

Pojęciem makrostruktury społecznej określa się specyficzny dla danego systemu, czy grupy społecznej układ klas, warstw czy kategorii społecznych w odpowiedni sposób funkcjonalnie ze sobą powiązanych. Przy szerokim pojmowaniu makrostruktur społecznych z uwzględnieniem wielkości objętej strukturą zbiorowości i jej względnej autonomii oraz organizacji elementów struktury, zalicza się doń zespoły i zrzeszenia, partie polityczne, grupy etniczne, narody, państwa. Makrostruktury odnoszą się do tych elementów systemu społecznego, które stanowią wydzielone ramy życia społecznego.

Złożoność makrostruktur społecznych odzwierciedla się w ich materialnym substracie, jak wielkość zbiorowości, zmiany zachodzące w jej składzie, zagospodarowanie terytorium, techniki znajdujące wyraz w wytwórczości i konsumpcji. Innym aspektem wypływającym z makrostruktury społecznej są systemy wartości, które społeczeństwo uznaje i preferuje, style 
i sposób życia tych zbiorowości i inne zjawiska badane przez socjologię makrostruktur społecznych. Makrostruktura wyróżnia się z wielu różniących się cech elementów i związków między nimi występujących, wykazujących historyczną zmienność oraz wielostopniowe uwarunkowania. Do kryteriów konstytuujących makrostrukturę społeczeństwa należy:

- rola jednostek i klas społecznych w systemie produkcji,

- określony status i role w działalności społecznej i zawodowej,

- elementy aksjologiczne wyrażające system norm, ocen i wartości,

- formy i fazy samorządności społecznej (14).

Podział socjologii na stanowiące opozycję mikrosocjologię i makrosocjologię nie wynika $\mathrm{z}$ rozpoznania problemu $\mathrm{w}$ systemie społecznym, ale $\mathrm{z}$ istnienia $\mathrm{w}$ społeczeństwie pojedynczych osobowości, małych grup, większych agregatów społecznych i wielkich formacji społecznych, a także z prób uczynienia osobowości i małej grupy społecznej, centrum badań socjologicznych.

Makrostruktury społeczne osiągają wewnętrzną spójność poprzez system wzajemnych oddziaływań, wartości i kultury. Procesy występujące w strukturach niższego rzędu mogą wpływać na zjawiska występujące w makrospołecznościach i społeczeństwie globalnym. Im bardziej te struktury są zróżnicowane i zarazem wewnętrznie spójne tym większa ich efektywność i siła oddziaływania. Głębsze poznanie struktur małych grup nie przynosi i nie może przynieść żadnych sugestii dotyczących rozstrzygnięć w dziedzinie makrosocjologii, ponieważ obydwie sfery zjawisk, oba typy struktur społecznych dzieli głęboka emergencja własności. Zatem problem stosunku mikrosocjologii do makrosocjologii wyrasta na podłożu przyjętej ontologii świata społecznego i epistemologii nauk społecznych.

Teoria socjologiczna $\mathrm{w}$ możliwie najszerszym tego słowa znaczeniu składa się $\mathrm{z}$ czterech poziomów:

a) Można mówić o poziomie teorii wyjaśniających jednostkowe działania, postawy, cechy osobowości pojedynczych jednostek ludzkich. Są to wszelkiego typu teorie psychospołeczne, w których centralnym przedmiotem dokonywanych wyjaśnień jest jednostka ludzka, jej cechy, regularności i prawidłowości zachowania oraz działania. Jest tak niezależnie od tego, czy źródeł jej działania należałoby poszukiwać w wewnętrznych strukturach ludzkiej psychiki, czy też w strukturze otoczenia społecznego. Jednostki ludzkie są w takich teoriach głównym eksplanandum.

b) Istnieje $\mathrm{w}$ teorii socjologicznej poziom teorii wyjaśniających działanie najelementarniejszych struktur ponadjednostkowych, takich jak układy ról, wewnętrzne struktury małych grup. Jest to poziom mikrosocjologii. Podczas gdy teorie psychospołeczne wyjaśniają zjawiska społeczne, lecz odnoszące się do jednostek ludzkich, mikrosocjologia wyjaśnia zjawiska społeczne lecz ponadjednostkowe.

c) $\mathrm{W}$ teorii socjologicznej można odnaleźć poziom teorii objaśniających wielkie procesy i wielkie struktury, poziom makrosocjologii. Obie dyscypliny makrosocjologia i mikrosocjologia chociaż wyraźnie są od siebie oddzielone, niemniej jednak nie obserwuje się między nimi przepaści. Nie sposób np. zbudować efektywnej teorii makrosocjologicznej, jeśli nie rozumie się dostatecznie mikrosocjologii i odwrotnie.

d) Obok teorii psychospołecznych, mikrosocjologii i makrosocjologii istnieje poziom orientacji socjologicznych wyjaśniających właściwości, działania i strukturę świata społecznego en bloc. Mikrosocjologia nie wyczerpuje w żadnym razie całej problematyki funkcjonowania mikroprocesów, a nie jest też dyscypliną drugorzędną czy pomocniczą 
wobec którejkolwiek z pozostałych. Autonomia mikrosocjologii sięga tak daleko, jak daleko procesy mikrostrukturalne determinują procesy makrostrukturalne oraz jak daleko same są zdeterminowane przez działanie i cechy procesów na poziomie działań jednostek (15).

\section{2. Między mikrosocjologią a makrosocjologią}

Świat społeczny jest światem dwóch odrębnych typów struktur, dwóch odrębnych poziomów integracji zjawisk społecznych, których odmienność wynika z różnicy jakościowej tych zjawisk, $\mathrm{z}$ ostrej emergencji właściwości charakterystycznych dla obusfer świata społecznego mikrostruktur i makrostruktur. Socjologia jest dyscypliną, której charakterystyczną cechą jest istnienie dwóch subdyscyplin makrosocjologii i mikrosocjologii. Pojawia się istotny problem, jak wypełnić lukę istniejącą między makro i mikrostrukturami. Kierunki tych poszukiwań są dość zróżnicowane i wobec tego, co wiąże poszczególnych badaczy, to przekonanie o konieczności wypełnienia luki.

Teza, którą wysuwa w tym względzie A. Kłoskowska polega na tym, że ów podział na mikro i makrostruktury nie jest podziałem dychotomicznym, w tym sensie, że istnieją takie typy zbiorowości społecznych, takie typy struktur, które ze względu na ich charakterystykę nie mogą być potraktowane ani jako makrostruktury, ani jako mikrostruktury społeczne. One też lokując się na pograniczu subdyscyplin jakby wypełniają lukę pomiędzy oboma poziomami rzeczywistości społecznej, powodując tym samym, że przejście od mikro do makrostruktur w sensie gwałtownego i ostrego przerwania ciągłości własności struktury świata społecznego, ostrej i gwałtownej nieciągłości jakościowej tego świata, staje się łagodniejsze i jakby bardziej kumulatywne. Otóż zdaniem Kłoskowskiej lukę tą wypełniają małe społeczności (16).

Badania małych społeczności można uznać za sferę graniczną pomiędzy mikrosocjologią i makrosocjologią. J. Duke, uważa, że rozwiązanie problemu leży raczej w metodologii i teorii socjologicznej. Chcąc pokonać przepaść dzielącą mikrosocjologię i makrosocjologię trzeba poszukiwać takich pojęć, które zarówno w jednej jak i drugiej subdyscyplinie są obecne (17).

Sposób rozwiązania problemu podobny do stanowiska Kłoskowskiej przyjął $M$. Crozier. Zakłada on, że organizacje społeczne są tym typem zbiorowości i społecznych struktur, które stanowić mogą pomost między mikrosocjologią i makrosocjologią. Z kolei teoria organizacji, to szczególny rodzaj uprawiania teorii na obszarze socjologii, w obrębie którego istnieje możliwość wykorzystania hipotez i teorii wypracowanych na mikro i makrosocjologicznym poziomie (18).

Podobne problemy analizuje P. Rybicki. Uważa on, że istnieje wyraźny związek miedzy ontologią świata społecznego, a strukturą teorii socjologicznej, choć nie sądzi, aby był on zbyt silny i wyraźny. Nie można w żaden sposób założyć, że istnieje ścisły związek między realistycznym i nominalistycznym podejściem, a podziałem teorii socjologicznej na makrosocjologię i mikrosocjologię. Nie sposób, zdaniem Rybickiego, sensownie rozstrzygnąć problemu wzajemnych relacji miedzy mikrosocjologią i makrosocjologią, nie zakładając wcześniej jakiejś ontologii rzeczywistości społecznej (19).

Przestrzeń między mikrostrukturami a wielkimi makrostrukturami jest zbyt duża. Stąd też podział na wielkie i małe społeczności nie zawsze jest w pełni adekwatny do obiektywnej rzeczywistości społecznej. W makrostrukturach można wyróżnić części i elementy wyższego i niższego rzędu. Zakres pierwszych obejmuje większe zbiorowości, instytucje i grupy społeczne. Drugi zawiera mniejsze zbiorowości, w pełni jednak ustrukturalizowane i dojrzałe społecznie. W rozważaniach jest przyjmowany układ pośredni, jako pomost miedzy małymi i wielkimi strukturami społecznymi. Układom takim można nadać nazwę mezostruktur 
społecznych, lub struktur pośrednich, występujących między biegunami pozostałych. Makro-, mezo- i mikrostruktury społeczne tworzą odmienny obraz struktury społecznej świata od przyjmowanego dotychczas. W obrębie mezostruktur różne elementy i relacje nie są zawsze zharmonizowane, podlegają więc sprzecznościom. Oznacza to współistnienie w różnych strukturach sprzecznych tendencji, które zwykle stanowią pewien przejściowy stan. Zmiany w strukturach wykazują charakter nie tylko endogenny, ale też ulegają zmianom wywołanym przez czynniki zewnętrzne. Zważywszy, że struktury mają swoją lokalizację przestrzenną, funkcjonują w sferze czasu i kultury, odzwierciedlają tym samym zachowania, postawy, zdarzenia i formy świadomości społecznej. Są więc obiektami społecznymi podlegającymi zmianom jakościowym i ilościowym.

W mezosystemie społecznym występują zbiorowości lokalne i terytorialne oraz ich struktury historyczne wytworzone i względnie trwałe, np. kulturowe, ekonomiczne, komunikacyjne, integracyjne, instytucje $\mathrm{i}$ zrzeszenia, ruchy i procesy społeczne, np. integracja, różnicowanie, konformizm, dewiacje, ruchliwość, nowe obszary zachowań w przestrzennym oraz czasowym układzie mezostruktur (20).

Społeczeństwo stanowi jedność wszystkich swoich poziomów. Wydzielenie mikro, makro czy mezoobiektów jest zabiegiem wyłącznie poznawczym, spowodowanym określonymi właściwościami poznania socjologicznego, nie ma zaś nic wspólnego z ontologiczną strukturą świata społecznego.

Struktury mezospołeczności należą do kluczowych pojęć socjologii. W koncepcji teorii wielopoziomowej, oprócz mikro i makrostruktur społecznych stanowią one wyodrębnione i autonomiczne poziomy rzeczywistości społecznej. Sytuacja strukturalna w mezospołeczności wpływa na stabilność grupy, jej równowage i rozwój, choć czasem doprowadza do zniewolenia członków oraz schizmatycznego układu strukturalnego, wywołującego zachowania antynormatywne. Mezospołeczność charakteryzuje się względną spójnością, podobieństwem postaw i potrzeb oraz zróżnicowanym układem sił społecznych sprzyjających bądź hamujących osiąganie celów ustalonych i zaakceptowanych przez grupę. Znane są cztery rodzaje sił społecznych, które nie pokrywają się z podziałem na klasy i warstwy. Należą do nich:

- siły promocyjne, grupy społeczne mające interes w osiąganiu przez strukturę wyższych stadiów rozwojowych,

- siły rozkładowe, grupy zainteresowane zmianą swojej dotychczasowej pozycji,

- siły korekcyjne (przeciwrozkładowe).

Wewnętrzna spójność i silniejsze związki strukturalno - funkcjonalne mezospołeczności warunkują też większe i skuteczniejsze przekazywanie norm i wartości w grupie. Wówczas jednak układy makrostrukturalne powodują blokadę działania swoich członków, ograniczając sfery ich wolności, a przez to następują procesy dezintegracji i zanikania związków z szerszym systemem (21).

Po to, aby w kategoriach empirycznych odpowiedzieć na pytanie o zależność jednostki od społeczeństwa, należy zbadać funkcjonowanie w społeczeństwie grup pierwotnych. Niewątpliwie należy do nich wspólnota. Zawsze będą istnieć takie dziedziny życia społecznego, takie szczególne zadania, czy funkcje w strukturze społecznej, które mogą być pełnione jedynie dzięki odpowiedniemu działaniu grup pierwotnych. Każda grupa pierwotna nadaje się do wykonywania zadań, których organizacja nie byłaby $\mathrm{w}$ stanie spełnić $\mathrm{i}$ odwrotnie. Totalne zablokowanie, ujarzmienie i podporządkowanie tych społeczności powoduje silny opór i tendencję do zamykania się wewnątrz grupy, skupienie się na własnych problemach i pogłębianie oderwania się od celów i zadań makrosystemu. 
Wynikiem takiego zjawiska jest spadek zaufania do wszelkich instytucji formalnych. W aktualnym stanie każdy makrosystem uzależniony jest od mikro i mezospołeczności, potrzebuje ich do wyjścia z kryzysu (22).

\section{3. Emergencja zjawisk społecznych}

Emergencyjny strukturalizm socjologiczny wysuwa tezę o występowaniu własności emergentnych na poszczególnych poziomach integracji świata społecznego. Emergencyjność, czyli jakościowa różnorodność zjawisk społecznych przejawia się $\mathrm{w}$ istnieniu różnych obszarów rzeczywistości społecznej zwanych poziomami, charakteryzujących się jednorodnością wewnętrzną, ale między sobą różniących się jakościowo. Emergencyjność strukturalna zakłada takie rozumienie pojęcia emergencji, zgodnie z którym można twierdzić, że w stosunku do danego obiektu społecznego można wskazać istnienie nieprzewidywalnych (na podstawie analizy elementów składowych) charakterystyk tej całości społecznej, tzw. nowości. Istnienie nowości, własności nieprzewidywalnych na podstawie analizy elementów składowych całości i wzajemnych relacji nie wynika z powodów formalno-logicznych tj. nie stanowi rezultatu niemożliwości wydedukowania zadań o tych nowych własnościach przysługujących danemu obiektowi, jako całości i wzajemnych powiązaniach, lecz jest istotną ontologiczną własnością świata. Nie chodzi więc o to, że własności całości nie mogą być rozpoznane. Przeciwnie są one dokładnie znane i zbadane, lecz w żaden sposób nie wynikają ze zdań o własnościach elementów składowych. Rzeczywistość zdaje się charakteryzować nieciągłością swych własności. Nie jest to ciąg kumulujących się własności, lecz raczej układ odrębnych jakościowo, aczkolwiek wzajemnie warunkujących się poziomów. Twierdzenie o emergencji jest kluczowe wobec rozumienia rzeczywistości społecznej.

Wedle emergencyjnego strukturalizmu socjologicznego, struktura świata społecznego, w jej najbardziej abstrakcyjnej postaci, jest strukturą trzech poziomów integracji zjawisk społecznych. najbardziej elementarnym poziomem świata społecznego jest poziom działających jednostek, jest to poziom substratu społeczeństwa, poziom tworzywa, z którego zbudowane są wszelkie pozostałe, typowo społeczne formy tego świata. W odróżnieniu od tego, czym są ludzie, jako indywidualne jednostki, najmniejsze ponadindywidualne zjawiska, procesy i struktury społeczne okazują się być odmienne jakościowo od zachowań indywidualnych. Już te najprostsze elementarne rodzaje ponadindywidualnych struktur okazują się być emergentne jakościowo od zachowań poszczególnych jednostek ludzkich. Jakkolwiek czym innym są zespoły poszczególnych ról społecznych, a czym innym struktury małych grup społecznych, to jednak istnieje dość daleko idąca tożsamość podstawowych, istotnych cech i właściwości strukturalnych i globalnych tych zjawisk. Powoduje to, że małe struktury społeczne, te różnorodne konstelacje i układy strukturalne pomimo pewnych różnic, są, ze względu na istotne głębokie własności, bardzo sobie bliskie. Można powiedzieć, że właśnie pomiędzy tymi różnorodnymi typami małych struktur społecznych, nie występuje jakaś zasadnicza, głęboka emergencja własności. W tym sensie tworzą one kolejny, drugi poziom integracji zjawisk społecznych. Trzecim i najbardziej kompleksowym poziomem integracji zjawisk społecznych jest poziom struktury rzeczywistości społecznej, odnoszący się do świata społecznego en bloc (23).

Emergentny strukturalizm socjologiczny nie zajmuje się badaniem zachowania społecznego. Bada raczej wewnętrzną mechanikę struktur społecznych, reguły funkcjonowania tych struktur jako całości, rodzaje związków między nimi a poszczególnymi ich elementami. 
Pomiędzy wspomnianymi wyżej poziomami integracji świata społecznego, według strukturalizmu emergencyjnego, nie ma płynnego przejścia, ich własności cechuje istotna jakościowa różnica, zasadnicza jakościowa autonomia. Własność emergencji przypisuje się bardzo dużym obszarom rzeczywistości społecznej, nie zaś poszczególnym cechom, czy zdarzeniom.

Koncepcję emergencji można traktować jako koncepcję w przeważającej swej części o charakterze logicznym. Stąd też emergencja nie jest charakterystyką rzeczywistości, lecz charakterystyką naszej wiedzy o rzeczywistości. Głównym zagadnieniem emergentyzmu jest problem przewidywalności cech złożonej całości na podstawie właściwości jej składników. Koncepcja emergentyzmu byłaby tezą, iż cechy złożonej całości są $\mathrm{z}$ reguły nieprzewidywalne, na podstawie analizy jakościowej jej składników. Emergencja ma sens wówczas, gdy potraktujemy ją wyłącznie jako tezę formalno-logiczną o zachodzeniu określonych związków między pewnymi zdaniami. Orzekanie w tym kontekście czegokolwiek o rzeczywistości miałoby sens wtedy, gdybyśmy doprowadzili do pełnej unifikacji naszej wiedzy. Istotną cechą koncepcji emergencji jest twierdzenie o istnieniu nieprzewidywalnych charakterystyk danej złożonej całości.

Rysują się w trakcie badań dwie wizje nauki. W pierwszym przypadku, gdy mamy do czynienia z logiczno - metodologiczną interpretacją emergencji, chodziło o naukę w formie systemu aksjonormatywnego, lub co najmniej systemu, w obrębie którego $\mathrm{z}$ niewielkiego zespołu przesłanek wyprowadzałoby się wszystkie pozostałe twierdzenia nauki. W drugim przypadku rzeczywistość wydaje się charakteryzować nieciągłością swoich cech. Nie jest to ciąg kumulujących się właściwości, lecz raczej układ wielu odrębnych jakościowo, choć wzajemnie warunkujących się poziomów. Istnieje jeszcze trzeci sposób interpretacji zjawiska emergencji. Rozumowanie jakie się w tym przypadku przeprowadza, ma wiele wspólnego z interpretacją logiczno - metodologiczną ale wprowadza także na tyle istotne różnice, aby potraktować je jako odrębne zjawisko. Rzeczywistość emergentna to rzeczywistość wielopoziomowa. Istotą emergencji jest więc nieciągłość cech danej rzeczywistości, pociągająca za sobą $\mathrm{w}$ konsekwencji konieczność rozpatrywania tej struktury jako wielopoziomowego układu.

Właściwością emergentną może być jakakolwiek charakterystyka, cecha danego przedmiotu, ale także określony proces, zjawisko, określona prawidłowość zachodzenia zjawisk czy procesów w obrębie rzeczywistości danego typu. Problem emergencji nie jest, jak wydaje się, problemem $\mathrm{z}$ dziedziny epistemologii. Dotyczy on podstawowych strukturalnych cech rzeczywistości, nie zaś sposobów jej wyjaśnienia (24).

\section{4. Struktury dalekiego i bliskiego zasięgu (dystansu)}

W warstwie teoretycznej mikrosocjologia wysuwa tezę, że trzy typy struktur społecznych mają podstawowe znaczenie dla przebiegu procesów mikrospołecznych: tzw. struktury quasi-grupowe, struktury bliskiego i dalekiego dystansu.

Struktura dalekiego dystansu jest rodzajem geometrii i formy, pola sił łączącego w jedną całość różnorodne zjawiska pochodzące z danego poziomu rzeczywistości społecznej. Struktur dalekiego dystansu jest tyle, ile istnieje poziomów rzeczywistości społecznej. Strukturą dalekiego dystansu jest wspomniana struktura emergencyjna świata społecznego. Struktura dalekiego dystansu jest strukturą ukrytą i jej wykrycie jest równoznaczne $\mathrm{z}$ dotarciem do istoty badanych zjawisk. Jest to także struktura głęboka, ponieważ stanowi rodzaj niewidocznego, wewnętrznego szkieletu zjawisk danej kategorii. Struktura dalekiego dystansu nie jest całością społeczną w sensie przedmiotu społecznego, a mimo to istnieje realnie, tak jak istnieją poszczególne formy geometryczne. 
Kiedy zastosujemy $\mathrm{w}$ analizie dystans bliski gdy spojrzymy na dany obiekt $\mathrm{z}$ niewielkiej odległości, okaże się, że jego struktura jest innego rodzaju niż struktura dalekiego dystansu. Będzie to już określona substancjalna całość. Strukturę bliskiego dystansu można porównać do kośćca. Jego wykrycie pozwala zrozumieć wiele ze sposobów działania organizmu ludzkiego, aczkolwiek nie umożliwia nam zrozumienia wszystkich zjawisk zachodzących w tym organizmie. Struktura bliskiego dystansu jest rodzajem całości społecznej, jest substancjalnie rozumianym przedmiotem istniejącym w rzeczywistości społecznej. Każdy obiekt (całość społeczna) ma wiele struktur bliskiego dystansu i dopiero rozpoznanie większości tych struktur uprawnia nas do wypowiedzenia tezy o rozpoznaniu cech i własności badanego przedmiotu. Struktura bliskiego dystansu ma zdolność determinowania określonych cech i właściwości, zarówno odpowiednich elementów przedmiotu społecznego, jak też cech i właściwości tego przedmiotu jako całości. Struktura bliskiego dystansu jest układem stosunków, zależności i wzajemnych oddziaływań między elementami danego przedmiotu społecznego.

Mikrostruktura jest trójwymiarowym układem społecznym (przestrzenią społeczną). Wszystkie trzy typy mikrostruktury powinny być interpretowane w kategoriach struktur bliskiego dystansu, odpowiedzialnych za dany wymiar struktury dalekiego dystansu. Wzajemne powiązania struktur bliskiego dystansu powodują, że strukturalnie regulowane zachowanie jednostki jest wypadkową działania wielu z nich. Każda struktura bliskiego dystansu działająca w obrębie pola mikrostruktury wytwarza systemy wartości. Jako wypadkowa działania zauważalna staje się powstająca przestrzeń wartości mikrostruktury. Wzajemne powiązanie struktur bliskiego dystansu powoduje, iż strukturalnie zdeterminowane wartości, strukturalnie regulowane wzory kulturowe oraz strukturalnie kontrolowane procesy socjalizacji są wypadkową działania wielu z tych struktur (25).

Zróżnicowanie spojrzenia na bliskie i dalekie dystanse jest niezbędne do tego, by można było rozpoznać różnorodne typy struktur społecznych. Niemożliwe jest pełne rozpoznanie, przy użyciu tylko jednego rodzaju dystansu. Gdy zastosujemy w analizie dystans daleki, a więc gdy spojrzymy na dany obiekt z maksymalnie dużej odległości, okazuje się, że jego struktura jest rodzajem geometrii układu, stanowi rodzaj ogólnej formy, jaką posiadają różnorodne obiekty społeczne. Można wówczas dostrzec określony układ, siatkę powiązań, ale będzie ona miała charakter wysoce abstrakcyjny. Jeśli patrzymy z dostatecznie dużej odległości na piramidy egipskie jesteśmy w stanie dostrzec jedynie ogólną ich formę geometryczną tj. trójkąt, ostrosłup, co przy użyciu wiedzy geometrycznej pozwala zrekonstruować własności i cechy takiej struktury.

Zastosowanie na gruncie socjologii takiego dystansu, takiej perspektywy poznawczej, umożliwi badaczowi dotarcie do struktur o zasięgu makro i mikro jak również do struktury zachowań działających jednostek. Właśnie mikrostruktura, czy makrostruktura mają charakter geometrycznego układu, niezmiernie abstrakcyjnego, niewątpliwie będącego ukrytą strukturą lub tzw. strukturą głęboką, realnego aczkolwiek abstrakcyjnego, tak jak realne są formy geometryczne i prawa nimi rządzące, nie dające się jednak rozpatrywać $\mathrm{z}$ substancjalnego aspektu.

Mikrostruktura jest ex definitione strukturą dalekiego dystansu. Nie jest ona tego typu obiektem, którego my ludzie, jako uczestnicy życia społecznego moglibyśmy bezpośrednio doświadczyć.

Jest to natomiast układ odniesienia, układ sił i napięć, pewna forma, geometria jaką przybierają zjawiska i procesy mikrosocjologiczne. Idea struktury dalekiego dystansu wywodzi się nie $\mathrm{z}$ przekonania o potrzebie dysponowania odpowiednim narzędziem 
wyjaśniającym, lecz raczej $\mathrm{z}$ przekonania o istnieniu $\mathrm{w}$ świecie społecznym tego typu głębokich ukrytych podstawowych struktur.

Odmienność jakościowa obu ww. typów dystansów polega na tym, że pewne typy struktur i zjawisk są dostrzegalne jedynie na mikrostrukturalnym poziomie integracji zjawisk społecznych $\mathrm{i} w$ tej postaci $\mathrm{w}$ obrębie zjawisk $\mathrm{z}$ innych poziomów rzeczywistości nie występują.

\section{5. Socjologia wartości}

Socjologia jest dla W. Thomasa, bliskiego współpracownika F. Znanieckiego nauką o wartościach społecznych, nie zajmuje się więc tym wszystkim, co jako rzeczywistość społeczna było opisywane przez H. Spencera i E. Durkheima. Socjologię wartości interesują wyłącznie te aspekty rzeczywistości społecznej, które w danym momencie i w danej grupie uzyskują znaczenie dzięki odnoszącym się do nich postawom.

Według T. Parsonsa, wartości są traktowane jako reguły interakcji odzwierciedlające ustalony już stopień osiągniętej przez uczestników zgody (26).

Miejscem realizacji wartości jest grupa społeczna. Jest ona ponadosobowym systemem wartości działań, które są wspólne dla wszystkich jej członków i obejmującym te wszystkie wartości i działania, które należą do ich ról, jako członków grupy. Część nakazów i nacisków strukturalnych nigdy nie przedostaje się do struktur osobowościowych człowieka, wobec tego nigdy nie zostaje uznana za własne przekonania danego człowieka i jego powinność. Nawet, gdy przedostaną się do struktur osobowości jednostki, stratyfikacja, czyli pewne hierarchiczne ułożenie tych wartości, jest zasadniczo odmienna od hierarchii struktury wymogów zewnętrznych.

W tym drugim przypadku jednostka pomimo internalizacji norm i wartości pochodzących z zewnętrznych nakazów, nigdy nie będzie się z nimi identyfikowała.

Granice optymalnej wolności i nacisków strukturalnych zawsze można wskazać, aczkolwiek ulegają one przesunięciu w jedną lub drugą stronę, w zależności od tego jakiego rodzaju wartości, potrzeby i dążenia zostały usankcjonowane przez kulturę grupy. W badaniach nad systemem wartości społeczeństwa polskiego S. Nowak odkrył istnienie specyficznego typu luki strukturalnej. Jej bliższe zbadanie pozwoli określić kierunek modyfikacji twierdzenia o dwustopniowości procesu komunikacji. Dążąc do ustalenia hierarchii ważności różnorodnych przedmiotów społecznych, S. Nowak zauważył, że w Polsce najważniejszym przedmiotem dla każdego człowieka jest on sam. Dlatego też zespół wartościowań: potrzeby - aspiracje -oczekiwania - normy właściwego zachowania - nadzieje i obawy, który jest powiązany $\mathrm{z}$ warunkami istnienia człowieka, tworzy najbardziej rozwinięty, a zarazem istotny zespół kryteriów, wartościowany w życiu każdego człowieka.

Im silniejsze i im częstsze interakcje między danymi grupami i jednostkami społecznymi, tym bardziej stają się one podobne pod względem norm i wartości. Im słabsza łączność lub interakcje, tym silniejsza tendencja do powstawania konfliktów między makro i mikrostrukturami. Jeżeli silne i liczne grupy pierwotne są wrogo nastawione do celów i wartości makrostruktur to istnieje duże prawdopodobieństwo, że wpływ makrostruktur na działające jednostki zostanie zakłócony lub zahamowany. Jeżeli silne i liczne grupy pierwotne są wrogo nastawione do celów i wartości makrostruktur, to jest bardzo prawdopodobne, że oddziaływanie jednostek na makrostruktury doprowadzi do ich rozbicia lub zakłóci ich poprawne funkcjonowanie. 
Każda ze struktur bliskiego dystansu wytwarza określone typy wartości i wzory kulturowe. Tak więc mikrostruktura może być definiowana jako pole ścierających się ze sobą systemów wartości i wzorów kulturowych. Trójwymiarową przestrzeń mikrostruktury można, w celu pomiaru poszczególnych wartości, zredukować do dwuwymiarowego pola, w obrębie którego jest możliwe zlokalizowanie każdego typu wartości i wzoru kulturowego. Chociaż ze słowem "wartość" spotykamy się obecnie w wielu dziedzinach nauki, jednak jego bliższe określenie wywołuje wiele problemów. Biorąc pod uwagę fakt, że najbardziej cenione przez ludzi wartości utrzymują się w ciągu wielu wieków w świadomości kolejnych pokoleń różnych społeczeństw, można zgodzić się z tym, że są one autonomiczne w stosunku do ludzi z poszczególnych epok (27).

Definicje ujmują słowo wartość jako przedmiot szanowanego lub pożądanego dobra materialnego lub niematerialnego, wzorzec względnie model ukierunkowujący działania i sposoby zachowania się ludzi, przejaw stosunku podmiotu do przedmiotu, który jest wyrazem jego oceny.

Niewątpliwie wszystko co istnieje $\mathrm{w}$ naturalnym bądź społecznym środowisku człowieka, jak twór przyrody, wytwór społeczny, czy też jego dziedzictwo kulturowe, ma dla ludzi potencjalną wartość, która $\mathrm{w}$ określonym momencie i warunkach może się zaktualizować, tzn. znaleźć się w świecie wartości uznawanych i szanowanych w danym społeczeństwie. Aktualną wartością staje się zatem wszystko to, co zyskuje szczególne uznanie danego człowieka, lub grupy ludzi w danym momencie, ze względu na jego lub ich potrzeby materialne, poznawcze, egzystencjalne, etyczne itp.

Środowisko naturalne jest pierwotne w stosunku do środowiska społecznego. Istniało bowiem zanim pojawili się ludzie, którzy stali się jego nowym swoistym elementem. Świat wartości składający się na trzecie środowisko istnienia człowieka, to twór wtórny zarówno w stosunku do jego środowiska naturalnego, jak i społecznego.

Wartości istnieją obiektywnie, jako określone wytwory środowiska naturalnego lub społecznego, które stanowiąc elementy tych środowisk ze względu na swoje właściwości, są dla danych ludzi szczególnie cenne. Występują one również subiektywnie (lub intersubiektywnie) jako szczególnie cenione, np. ideały, racje istnienia, wzory doskonałości itp. twory idealne preferowane przez danych ludzi, ich zbiory na zasadzie zbiorowych wyobrażeń. Brak przy tym dostatecznie uzasadnionych postaw do przyjęcia tezy o istnieniu jakiejś jednolitej hierarchii wartości nie tylko $\mathrm{w}$ świecie wartości, ale nawet $\mathrm{w}$ poszczególnych jego elementach, jakimi są różne układy wartości. Istnieje zatem wiele hierarchii wartości $\mathrm{w}$ danych układach wartości, które są zdeterminowane obiektywnie przez systemy społeczne, w których funkcjonują, a subiektywnie - przez aspiracje, pragnienia i postawy poszczególnych ludzi.

Zarówno warunki obiektywne jak i subiektywne ulegają zmianom, co nie pozostaje bez wpływu na istniejące hierarchie wartości. Oderwany od realiów, czyli przyrody i społeczeństwa świat wartości składa się z hipostaz mogących stać się źródłem rozmaitych fikcji oraz złudzeń, zwłaszcza wówczas, gdy zapomina się o tym, że słowa mogą być po prostu wytworem ludzkiego intelektu. Oderwany od realiów świat wartości może ulec procesowi mitologizacji i stać się przedmiotem swoistego kultu. Wielość i różnorodność wartości skłania do refleksji nad możliwościami ich uporządkowania według określonych kryteriów. Do najczęściej przytaczanych w literaturze naukowej zaliczamy podziały na wartości:

- autoteliczne (będące celem samym w sobie) i instrumentalne (stanowiące środek do ich osiągnięcia),

- deklarowane i realizowane, 
- abstrakcyjne i konkretne,

- trwałe i efemeryczne,

- racjonalne i irracjonalne (28).

Podział na wartości autoteliczne (cele) i instrumentalne (środki) jest arbitralny. można go stosować w sposób uzasadniony wówczas, gdy wchodzi w grę jakiś cel ostateczny i jedyny.

Podział na wartości deklarowane i realizowane wyrasta z ukazanej przez I. Kanta różnicy między tym co jest (byt), a tym co powinno być (powinność) (29).

Zdarza się, że z różnych względów ludzie nie zawsze realizują deklarowane wartości, podobnie jak też nie zawsze deklarują wartości realizowane, żyjąc mniej lub bardziej w świecie fikcji bądź moralnej dwuznaczności.

Podział na wartości abstrakcyjne i konkretne wcale nie jest wystarczająco wyraźny. Wartości abstrakcyjne bywają często utożsamiane z różnymi ogólnikami, których potencjał informacyjny jest niewielki, dopóki nie zostaną sprecyzowane bliżej. Konkretyzacja jednak często ogranicza się do uogólnień, czyli abstrakcji, a tym samym ukazuje logiczne dylematy związane z możliwością korzystania z omawianej typologii. Jedną z prób przezwyciężenia tej trudności jest propozycja S. Ossowskiego zmierzająca do wyróżnienia wartości uroczystych i życia codziennego. Pierwsze wynikają z pewnych przeżyć zbiorowych, drugie związane są z sukcesami osiąganymi przez jednostki lub małe grupy w trakcie ich codziennych zmagań $\mathrm{z}$ otoczeniem (30).

Podział na wartości trwałe i nietrwałe określa ich stabilność. Wartości trwałe są przekazywane z pokolenia na pokolenie wykazując nieprzemijającą żywotność i budząc powszechną akceptację. Wartości efemeryczne są przejściowe i zmieniają się jak moda pod wpływem doraźnych potrzeb i sytuacji. Wartości, które uległy dezaktualizacji i ze względu na swój krótki żywot, okazały się efemerydami, nie zanikają zupełnie, nawet jeśli są przez pewien czas zapomniane. Rozróżnienie na wartości racjonalne i nieracjonalne nie jest łatwe. Racjonalne są te wartości, które $\mathrm{z}$ aspektu aktualnego stanu wiedzy są $\mathrm{w}$ jakimś stopniu prawdopodobne, a tym samym nie mogą być urzeczywistnione nawet $\mathrm{w}$ minimalnym stopniu. Interesującą koncepcję systemu wartości zaprezentował L. Lavelle, wychodząc od faktu istnienia jedności i mnogości bytu oraz wartości. Wyróżnił on wartości fundamentalne, redukując jedno z trzech (prawda, piękno i dobro), które stanowią podstawę bardziej szczegółowych wartości intelektualnych, estetycznych oraz moralnych. Współtworzą one jeden komplementarny system. Ponadto wydzielił on przenikające się nawzajem wartości ekonomiczne i afektywne. Pierwsze $\mathrm{z}$ nich są współokreślane przez użyteczność, nakład pracy, a także rzadkość występowania. Wartości afektywne wiążą się ze wzruszeniami. miłością, odczuciami, przyjemnościami i cierpieniem, wychodząc z założenia, że wartości i uczucia są nierozdzielne (31).

\section{6. Socjologia religii}

Socjologia religii jest nauką młodą, znajduje się na początku swego rozwoju i jak dotąd nie zyskała zbyt wiele pewności co do jej przedmiotu i metod. Socjologia religii nie jest dyscypliną religijną lecz socjologiczną, tzn. zajmuje się w sposób naukowy badaniem współżycia ludzi zespolonych $\mathrm{w}$ grupy religijne. Zawiera się w tym pytanie o wpływ religii na społeczeństwo i vice versa. Socjologia religii ma za swój przedmiot związki i interakcje zachodzące między religią a społeczeństwem. Sama religia jest metaspołecznym fenomenem, który przerasta jednostkę i społeczeństwo. Taka koncepcja przebija w dawnej socjologii religii M. Webera, E. Troeltscha, M. Sombarta nazwana później klasyczną socjologią religii 
(32). W staraniach by dzieło swoich poprzedników uporządkować J. Wach podjął temat socjologii religii, którą zdefiniował, jako dyscyplinę zajmującą się wzajemnymi wpływami religii i społeczeństwa oraz strukturą zachodzących między nimi interakcji. Traktuje on religię jako czynnik społecznej integracji, wyrażający się $\mathrm{w}$ dogmatach, kulcie i stowarzyszeniach religijnych. Ten ostatni element ma szczególne znaczenie dla socjologii religii, która powinna główny nacisk kłaść na typologię grup religijnych.

H. Schelsky stwierdza, że centralnym zagadnieniem współczesnej socjologii religii jest badanie sposobów przystosowania się religii do społeczeństwa. Pojęcie przystosowania zacieśnia on do zmian społecznych form chrześcijaństwa (33).

P. Smits określił to stwierdzenie Schelsky'ego jako próbę odnowy socjologii religii. Według tego ostatniego należałoby pożegnać się z klasyczną socjologią religii i postawić na pierwszym miejscu dostosowanie religii do nowoczesnego społeczeństwa (34). Według B. Häringa przedmiotem socjologii religii są wzajemne relacje między religią a społecznymi warunkami ze szczególnym zaakcentowaniem wspólnotowego charakteru religii (35).

M. Yinger konkluduje, że socjologia religii, jest w szerokim znaczeniu, naukowym badaniem sposobów, jakimi społeczeństwo kultura i osobowość wpływają na religię, tzn. wpływają na jej powstanie, doktrynę, na jej praktykowanie, typy grup, które ją wyznają, typy przywództwa itp. (36).

F. Fürstenberg wskazuje na sformułowaną przez M. Webera tezę sekularyzacyjną, która nadała współczesnej socjologii religii najważniejszy impuls. Socjologia religii rozwijała się jako nauka poprzez analizę historycznych i pierwotnych społeczeństw w których religia naturalna zajmowała centralne miejsce. Jej hipotezy i aparat pojęciowy są zorientowane na pozycję jaką religia i kościół zajmowały w tych warunkach (37).

Socjologia religii jest jeszcze związana $\mathrm{z}$ religią naturalną $\mathrm{i}$ charakteryzuje ją dychotomia natury i nadnatury. W swej problematyce i pojęciach jeszcze "nie strawiła" zagadnienia sekularyzacji (faktu pełnej dojrzałości współczesnego świata). Dla zdefiniowania tego stanu rzeczy socjologia religii potrzebuje pomocy innych nauk. E. Vogt wymienia w związku z tym przede wszystkim filozofię wartości i filozofię religii. Akcent powinien być położony na teologię i antropologię filozoficzną. Chodzi tu przecież o poznanie prawdziwej, odpowiedniej na dzisiejsze czasy religii i jej odbicia w życiu jednostkowym i społecznym (38).

Poszukuje się znów specyficznie chrześcijańskiej wspólnoty, braterstwa (koinonii). Ona nie jest zgromadzeniem ludzi, którzy przez wewnętrzne doświadczenie doszli do takiego samego obrazu świata, lecz łatwo przystosowującą się grupą zwróconą i otwartą na innych. Kościół jest sobą, gdy służy innym, gdy jest dla innych. W żywych małych grupach jest kładziony szczególny nacisk na służbę światu i kwestionowany statyczny, instytucjonalny model kościoła. Szczytowym osiągnięciem prawdziwej religii nie jest posiadanie wewnętrznej wiary i tworzenie zamkniętych grup, lecz uczestnictwo w życiu innych i troska o życie bliźnich. Według nowszych badań socjologowie religii zbytnio ulegają jeszcze tezie sekularyzacyjnej M. Webera, tak w odmianie zachodniej (sekularyzacja spontaniczna) jak i wschodniej (sekularyzacja sterowana). Z pierwszą wersją wiąże się sekularyzm (świeckość), $\mathrm{z}$ drugą laicyzm (ateizm). Stanowiska te musiały ulec zmianie wskutek poszukiwań szerszych czynników i procesów wpływających na religijność i instytucje religijne. Okazało się bowiem, że sekularyzacja stanowi tylko jeden z czynników oraz aspektów bardziej ogólnego procesu zmian. Nowoczesność występuje jako czynnik i proces przemian w opisach i analizach socjologii religii P. Bergera. Twierdzi on mianowicie, że nowoczesność polega na pojawieniu się $\mathrm{W}$ stosunku do świata tradycyjnego, nowych światów, związanych $\mathrm{z}$ możliwością wyboru w różnych dziedzinach, w tym także religijnej i kościelnej (39). 
Socjologia religii w Polsce długo była traktowana jako nauka kontrowersyjna. Korzenie tej kontrowersji sięgają zasadniczych nieporozumień dotyczących jej przedmiotu i metod. Wiązało się to z pewnym stylem jej uprawiania w okresie po IIwojnie światowej.

Styl ten polegał na bezpośrednim wiązaniu jej z filozofią i teologią. Nie była jasno sprecyzowana i uświadamiana sprawa, że socjologia religii jest dyscypliną socjologiczną, a nie teologiczną. Socjologia religii nie wypowiada się w sposób holistyczny. Zajmuje się badaniem pewnych aspektów religijności zwłaszcza jej wymiarów społeczno - kulturowych, przejawiających się w życiu ludzkich zbiorowości (40).

W. Goddijn w artykule "Pluralizm religijny, a chrześcijaństwo", określa z nieco innej strony poznawcze i moralne wartości socjologii. Podobnie jak Leclerq zauważa, że jej wyniki i metody kształtują świadomość różnorodności postaw i formacji religijnych w łonie katolicyzmu i każą tę różnorodność respektować. Wykazuje jednak równocześnie, że znajomość wspólnych uwarunkowań życia religijnego, zwłaszcza czynników historycznych, psychologicznych i socjologicznych wywiera wpływ jednoczący, likwidując niepożądane napięcia emocjonalne, prowadzące do reakcji niechrześcijańskich (fanatyzm, faryzejska pogarda). Wspomniany socjolog holenderski zajmuje się przede wszystkim mechanizmem powstania i izolowania się sekt oraz stosunkiem do społeczności je otaczających. W przeciwieństwie do klasyków tego tematu nie przeciwstawia on sekty kościołowi, tylko rozpatruje oba typy grup religijnych jako fazy procesu instytucjonalizacji i adaptacji do kultury otaczającej, procesu nieuchronnego dla trwałości i stabilizacji wszelkich wspólnot zorganizowanych (41).

Socjolog religii staje przed podwójnie złożonym zjawiskiem - paradoksem metodologicznym. $Z$ jednej strony religia jako zjawisko społeczne, jest ze względu na treściowy zakres definiendum trudno jednoznacznie definiowalna. $Z$ drugiej strony rygoryzm metodologiczny dopuszczał analizy na poziomie potocznego, subiektywnego czy jedynie intuicyjnego jej rozumienia. Definicyjne poszukiwania przez socjologów adekwatnego wobec współczesnych problemów określenia pojęcia religia, powodują, że termin ten coraz częściej pojawia się z dookreślającą charakter zjawiska przydawką. (42):

R. Towler dokonał zestawienia występujących w literaturze konotacji terminu religia

- religia konwencjonalna (oficjalna, eklezjalna)

- religia sektancka

- ruchy religijne

- religia ludowa (włączająca pozakościelną tradycję)

- religia obywatelska

- surogat religii (termin E. Durkheima - używany współcześnie przez zachodnią socjologię wobec komunizmu, psychoanalizy i humanizmu) - religia niewidzialna (43).

$\mathrm{W}$ badaniach socjologicznych niezmiernie trudno wydobyć, stosując środki w ramach typowych technik badawczych, subiektywne, często niepowtarzalne aspekty religijności prywatnej, tym bardziej, że socjologia religii nie zajmuje się wprost wewnętrznymi przeżyciami religijnymi człowieka, lecz następstwami doświadczenia religijnego ujawniającymi się $\mathrm{w}$ relacjach i interakcjach społecznych oraz określonym kontekście społeczno - kulturowym.

Tendencje występujące $\mathrm{w}$ światowej socjologii religii znajdują odzwierciedlenie $\mathrm{w}$ Polsce. W naszym kraju są prowadzone badania w kierunku opisywania rytuału religijnego, doświadczenia religijnego oraz wartości religijno - moralnych i ich przestrzegania. Różnorodne wymiary religijności dają się ułożyć w pewne szersze kompleksy. Kiedy 
rozważa się religijność bardziej od strony systemu wierzeń obejmującego całokształt codziennego doświadczenia człowieka i wszystkie sfery jego działalności, którym religia nadaje całościowy sens, da się wyróżnić w religijności trzy podstawowe elementy: doświadczenie religijne jednostki, kulturę religijną i działania religijne. Doświadczenie religijne ukierunkowane na Siłę Wyższą (Boga) polega na uznaniu i podporządkowaniu się Woli Bożej. Leży ono u podstaw zarówno kultury, jak i działań religijnych. Kultura religijna jest zbiorem przekonań wartości i symboli, które są dla ludzi wierzących nośnikiem całościowego sensu świata. Działania religijne powstają przez uznanie rzeczywistości sacrum. Socjologia religii koncentruje się na badaniach kultury i działań religijnych, nie roszcząc sobie pretensji do totalnego wyjaśniania religijnych postaw i zachowań ludzkich.

Drugie przegrupowanie wymiarów religijności dokonuje się w koncepcji tzw. płaszczyzn religijności: płaszczyzny ogólnonarodowej (wiara narodu) i płaszczyzny życia codziennego (religia życia). W pierwszym znaczeniu religijność jest zespolona $\mathrm{z}$ wartościami narodowymi i jawi się jako czynnik integracji, zarówno w odniesieniu do kultury jak i struktury społecznej. Religijność na płaszczyźnie życia codziennego, faktycznie przeżywana w życiu indywidualnym, rodzinnym, obejmuje wspomniane wyżej wymiary życia religijnego z wyjątkiem globalnych wyznań wiary i masowych praktyk religijnych. Oprócz stanowisk teoretycznych w socjologii ważne są kierunki, czy nurty badawcze. Podział na kierunki badań można przeprowadzić według sposobów uprawiania socjologii, według założeń teoretyczno metodologicznych, czy według rodzaju problematyki podejmowanej przez poszczególne ośrodki badawcze.

Opierając się na kryterium podejmowanej problematyki można uporządkować podejmowane zwłaszcza $\mathrm{w}$ latach osiemdziesiątych badania nad religijnością $\mathrm{w}$ następujący sposób:

- badania podstawowych wymiarów religijności,

- badania rytuałów religijnych i świeckich,

- badanie wspólnot i instytucji religijnych,

- badanie związków między religią, a innymi dziedzinami aktywności ludzkiej (44).

Najczęstszym, ale i najbardziej powierzchownym sposobem badania religijności społeczeństwa polskiego jako całości są sondaże reprezentatywne, realizowane na próbach ogólnokrajowych. Sondaże te spełniają ważną funkcję poznawczą, gdyż dostarczają informacji o zjawiskach religijnych i ich zasięgu w społeczeństwie. Stwarzają także dogodny punkt wyjścia do dalszych bardziej wszechstronnych badań socjoreligijnych. Sondaże opinii publicznej są $\mathrm{w}$ gestii kilku wyspecjalizowanych instytucji. Jeżeli istnieje coś takiego, jak potencjał religijny, to niewątpliwie został on w latach osiemdziesiątych niemal osiągnięty (zwłaszcza w wymiarach ogólnych deklaracji religijnych). Lata przełomu 1989 - 1993 to trwający spadek autoidentyfikacji religijnych w naszym społeczeństwie. Społeczeństwo polskie zbliżyło się w wymiarach autoidentyfikacji do granicy możliwości ekspansji religii, co wiązało się ze spadkiem osób indyferentnych i niewierzących (45).

$\mathrm{Na}$ ożywienie religijne w społeczeństwie polskim wskazuje analiza jednostkowych ważnych decyzji podejmowanych przez katolików niedzielnych (osoby uczestniczące w ten dzień do kościoła). Według zebranych i opracowanych danych w latach osiemdziesiątych dokonywał i pogłębiał się proces przewartościowania postaw i zachowań religijnych od konwencjonalnych i rytualistycznych do bardziej osobistych i wewnętrznych. Pogłębiało się poczucie przynależności do kościoła jako wspólnoty. Praktyki religijne w dalszym ciągu pełnią ważną rolę w integracji zbiorowości na płaszczyźnie norm i wzorców zachowań oraz wyznaczając podstawy ładu społeczno - kulturowego. 
Ważny dział badań nad religijnością stanowią te badania, które koncentrują się na problematyce różnych wspólnot $\mathrm{i}$ instytucji religijnych. Przedmiotem ich jest $\mathrm{np}$. rodzina $\mathrm{z}$ wyakcentowaniem jej funkcji religijnych, może być także parafia, diecezja, również instytucja kapłana i kapłaństwa oraz wspólnoty zakonnej. W ramach tej problematyki mieści się socjologia ruchów społeczno - religijnych i pseudoreligijnych (tzw. destruktywne kulty), przyjmujących mniej lub bardziej wspólnotowy charakter. Badaniami obejmowany jest także stosunek do kościoła jako instytucji społecznej. Wymienione zagadnienia mogą być rozważane także w ramach instytucjonalnego wymiaru religii.

Badanie wspólnot i instytucji religijnych obejmuje wiele interesujących zakresów problemowych. Przykładowo badania nad rodziną miejską i wiejską jako wspólnotą (także religijną) obejmują szeroki zakres zagadnień. Przed socjologią religii staje niezwykle istotny problem bliższego przeanalizowania zagadnienia religijnych funkcji rodziny $\mathrm{w}$ całym jej bogactwie i złożoności. Zagadnienie to staje się o tyle ważne, że z jednej strony żywiołowa i spontaniczna socjalizacja religijna $\mathrm{w}$ rodzinie należy już do przeszłości, $\mathrm{z}$ drugiej zaś strony kościół w ramach katechizacji i różnych form duszpasterstwa przejmuje w pewnym stopniu od rodziny niektóre funkcje religijne. Pozostaje jednak odpowiedź na pytanie: w jakim stopniu dokonuje się świadoma i intencjonalna transmisja wartości norm i wzorców zachowań właściwych kulturze chrześcijańskiej. Studia nad parafią katolicką jako wspólnotą religijną $\mathrm{w}$ socjologii polskiej mają długą tradycję. Zbierany od wielu lat materiał został przebadany pod kątem dwóch hipotez:

- poziom przynależności do parafii różnicuje się w zależności od wymiarów przynależności. Wyższy jest w wymiarze globalnych postaw wobec religii i praktyk religijnych, zaś niższy w wymiarze świadomości religijnej oraz identyfikacji i parafią.

- stopień przynależności do parafii jest uwarunkowany typem środowiska społecznego i kształtuje się następująco. Parafie w wielkich miastach, parafie w średnich miastach, parafie w małych miastach, parafie miejsko - wiejskie, parafie podmiejskie, parafie wiejskie.

Poziom przynależności do parafii różnicują także lokalne uwarunkowania historyczno duszpasterskie. Przynależność parafialna, to względnie stałe pozytywne lub negatywne ustosunkowanie się jednostki wobec parafii.

Bardzo częstym tematem badawczym bywa stosunek Polaków do Kościoła jako instytucji społecznej. W latach osiemdziesiątych autorytet kościoła wyraźnie zwyżkował. Od 1990 roku wyraźnie słabnie. Świadczą o tym wyniki badań socjologicznych.

Chwilowe załamanie autorytetu Kościoła w jednym punkcie jego nauczania oddziałuje negatywnie na inne dziedziny życia religijnego i kościelnego, tak jak wcześniej wzmocnienie autorytetu Kościoła w jednej sferze życia ludzkiego oddziaływało na inne.

Kościół w Polsce zwłaszcza w pierwszej połowie lat osiemdziesiątych pełnił wiele funkcji zastępczych, do których nie był wystarczająco przygotowany. Funkcje te nie leżały także w jego zasadniczym posłannictwie. Ważnym, choć stosunkowo zaniedbanym przedmiotem badań są powołania kapłańskie i zakonne.

Nowym fenomenem w panoramie polskiej religijności są powstające od połowy lat sześćdziesiątych ruchy odnowy i wspólnoty religijne. Obok tradycyjnych zespołów kościelnych, powstają nowe w ramach aktywności liturgicznej, katechetycznej, formacyjnej, studyjnej, modlitewnej, wspólnototwórczej, świadczenia sobie wzajemnej pomocy itp., mając na celu aktywny udział w życiu wielkiej wspólnoty Kościoła. Współdziałają one na zasadzie partnerstwa w posłannictwie Kościoła, pogłębiają religijne zaangażowanie laikatu, są bardziej radykalne i bezkompromisowe niż ogół wierzących. 
We wspólnotach religijnych człowiek może uwydatniać swoją indywidualność, czyli odnaleźć i zaznaczyć siebie jako jednostkę odrębną. Sens indywidualności ginie w masie, także kościelnej. We wspólnocie religijnej człowiek traktuje religię nie tyle według kryterium korzyści czy psychicznego komfortu, ale przede wszystkim jako zjawisko mobilizujące i dostrzegane, jako zajmujące ważne miejsce w systemie uznawanych wartości, będących istotnym elementem stylu życia. Wielkie wspólnoty kościelne nie mogą ze względu na swoją wielkość, strukturę i pełnione funkcje, zapewnić wiernym przestrzeń życiową na miarę ludzką oraz stworzyć warunki do subiektywnego i osobistego współudziału.

$\mathrm{W}$ związku z rozwojem małych grup religijnych w polskich parafiach coraz częściej mówi się o nowej funkcji parafii jaką jest propagowanie rozwoju małych grup religijnych (wspieranie, pobudzanie inicjatyw, koordynowanie). Chodzi o tworzenie dla wiernych takich środowisk społecznych, w których chrześcijaństwo będzie otwarcie wyrażane i akceptowane. W takich środowiskach człowiek znajdzie wsparcie dla realizacji swoich potrzeb religijno duchowych. Każdy członek parafii ma kontakt z wieloma środowiskami społecznymi. Idzie o to, aby przynajmniej jedno z tych środowisk dostarczało inspiracji chrześcijańskiej.

Należy liczyć się także z przenikaniem tzw. wspólnot destruktywnych. Kulty te przeciwstawiają się całkiem otwarcie chrześcijańsko - zachodniemu obrazowi człowieka i europejskiej kulturze. Wymownym przykładem powyższego jest kult satanistyczny. W środowiskach akademickich rozwijają się sekty niechrześcijańskie nawiązujące do buddyzmu i New Age. Część z nich została już nawet zarejestrowana jako wyznanie w Polsce.

Nowe ruchy religijne powstające w Stanach Zjednoczonych i Europie końca lat sześćdziesiątych były formą protestu intelektualno - światopoglądowego przeciw zdominowaniu życia społeczeństw zachodnich przez wartości materialne, formą protestu przeciw stosowanym metodom realizacji interpretacji życia społecznego. Proces ten objął odrzucenie panującej tam tradycji religijnej i zwrócenie się ku tradycji religijnej Wschodu. Szersza charakterystyka nowych wspólnot i ruchów religijnych byłaby istotna dla całokształtu obrazu życia religijnego współczesnej Polski. Większość tych ruchów sięga swymi początkami połowy lat sześćdziesiątych. Nowe ruchy i wspólnoty religijne nie dają się ująć w wyczerpującym opisie. Ich powstanie i rozwój wiąże się często z inicjatywami duszpasterzy, zdolnych do twórczego myślenia pastoralnego. Są one ważne w warunkach społeczeństwa pluralistycznego, w którym kościół nie oddziałuje już na społeczeństwo w sposób całościowy. Religijne wspólnoty $\mathrm{i}$ ruchy związane $\mathrm{z}$ kościołem są nowymi podmiotami socjalizacji i wychowania religijnego. Należałoby rozbudowywać możliwości wspólnotowych form życia religijnego, dzielić wielkie struktury kościelne na małe światy działające na miarę ludzką i sprzyjające upodmiotowieniu laikatu w kościele, także poza strukturami parafialnymi (46).

\section{7. Elityzm}

U większości socjologów pojęcie elita, teoria elit, wywołują jedynie mgliste skojarzenie z kursu historii socjologii, przywodząc na myśl takie nazwiska jak G. Mosca, V. Pareto, czy R. Michels (47-49).

Pojęcie elita władzy nieodparcie wiąże się z książką C.W. Millsa pod takim właśnie tytułem (50). Refleksja nad społeczeństwem w kategoriach elitystycznych ani nie zaczyna się na trzech wspomnianych wyżej klasykach, ani nie kończy na Millsie. Jest to pojęcie teoretyczne znacznie mocniej osadzone w tradycji i znacznie częściej wykorzystywane, niż na ogół się sądzi.

Wspólną cechą wszystkich koncepcji formułowanych w kategoriach elit, zarówno tych, które miały ambicje stać się uniwersalnymi teoriami społeczeństwa, jak i tych, które nie 
aspirowały do takiej roli, jest traktowanie władzy jako kluczowej cechy systemów społecznych, a tym samym podstawowej determinanty struktury społecznej.

Elityzm zawsze jest co najmniej teorią władzy społecznej i jej podziału, choć na ogół stara się być czymś więcej. Klasyczne stanowisko elitystyczne polega na przekonaniu, że władza skupiona jest w rękach wąskiej grupy ludzi, odgrodzonej od społeczeństwa szeregiem trudnych do przeniknięcia barier. Fundamentalna opozycja przebiega więc w społeczeństwie między elitą a masami. Elita jako grupa władcza o bardzo znacznym zakresie autonomii (w skrajnych przypadkach nieograniczonej autonomii) jest grupą zamkniętą (ekskluzywną). Elita legitymizuje władzę w sposób różnoraki. Odwołuje się do określonej formuły politycznej, akceptowanego społecznie systemu przekonań odnośnie źródła władzy, natury świata i człowieka, roli poszczególnych grup społecznych. W swoim działaniu elita opiera się na określonej sile społecznej. Ucieleśnia ją zazwyczaj jakaś grupa społeczna lub klasa społeczna. jedną z jej podstawowych cech, zarazem źródłem jej dominacji jest wewnętrzna organizacja i spójność. Jako mniejszość elita jest sprawniejsza organizacyjnie. Klasyczny paradygmat elitystyczny zakreślał przed sobą nader rozległy obszar badawczy i stawiał bardzo ambitne cele. Elity jawią się w nim nie tylko jako pozytywnie wyselekcjonowane, konieczne i niepodległe kontroli elementy systemu, lecz także jako podstawowe determinanty zarówno struktury, świadomości jak i zmiany społecznej. Elityzm w ujęciu amerykańskich badaczy G. Fielda i J. Higleya jest stanowiskiem, które akceptuje niezbywalność elit i przypisuje im sprawczą rolę w procesie historycznym (51).

Podstawową normatywną implikacją elityzmu jest to, że we wszystkich społeczeństwach, tak rozwiniętych jak i rozwijających się, społeczne przekonanie o możliwym, czy też pożądanym zakresie swobód i równości muszą brać pod uwagę istnienie elit. Elitę stanowią osoby zajmujące strategiczne miejsce w publicznych i prywatnych organizacjach. Modyfikacja podejścia klasycznego polega tutaj na ukazaniu w pierwszym rzędzie ograniczeń jakim ulegają elity. Wspomniani wyżej amerykańscy autorzy koncepcji elitystycznej wyróżniają trzy podstawowe i jeden poboczny typ elit, które mogą się ukształtować we wszystkich lub tylko niektórych społeczeństwach.

Najczęściej występującym typem elity jest elita sfragmentaryzowana (podzielona, rozbita, zdezintegrowana). Mamy $\mathrm{z}$ nią do czynienia wówczas, gdy zbiorowość osób zajmujących strategiczne pozycje w kluczowych organizacjach jest podzielona na frakcje, kliki i ugrupowania o przeciwstawnych stanowiskach.

Drugi podstawowy typ elity to elity zintegrowane (zunifikowane) wokó 1 jednej ideologii. Mamy do czynienia z nimi wówczas, gdy zwarty ruch społeczny o jasno wykrystalizowanej ideologii zdoła obsadzić swoimi ludźmi strategiczne pozycje organizacyjne. Tego rodzaju system raz wprowadzony ma zdolność do samoumacniania się.

Trzeci rodzaj elit, to elity zintegrowane wokół zespołu fundamentalnych wartości, wspólnych dla wszystkich grup składających się na elitę. Są to tzw. elity zintegrowane konsensualnie. Różnią się od poprzednich tym, że dopuszczają różnorodność systemów normatywnych, bazujących wszakże na tej samej nienaruszalnej podstawie. Kluczową cechą elit zintegrowanych konsensualnie jest ich zdolność do wchłonięcia i nadania kształtu tym zagadnieniom, których otwarte i dogmatyczne postawienie mogłoby prowadzić do wyniszczających konfliktów.

Czwartym (pobocznym) rodzajem elit, są elity nie w pełni zintegrowane (częściowo zjednoczone). Stanowią one fazę przejściową między elitami sfragmentaryzowanymi a konsensualnie zintegrowanymi. Skoro istnienie elit jest nie do uniknięcia, a zajmowanie pozycji w elicie nieuchronnie prowadzi do uprzywilejowań, należy skoncentrować się na 
tworzeniu elit najbardziej spójnych. Spójność elity, jej podstawa oraz społeczne i polityczne konsekwencje stanowią o swoistej hierarchii typów elit.

Współczesny elityzm wycofuje się z przekonań o szczególnych predyspozycjach przywódców oraz ich wyjątkowym poczuciu odpowiedzialności, rezygnując z podejścia indywidualistycznego na rzecz instytucjonalnego. Elita opiera swoją działalność na zinstytucjonalizowanych regułach gry, których przestrzega $w$ takim samym stopniu jak każda inna grupa społeczna. Każda elita zostaje po jakimś czasie zastąpiona przez inną po wyczerpaniu się energii, która pozwoliła jej wcześniej na zajęcie uprzywilejowanej pozycji. Nie ma żadnej grupy społecznej, która ze względu na swoje trwałe cechy byłaby predystynowana do zajęcia raz na zawsze pozycji elity. Są natomiast określone predyspozycje do wygrywania lub przegrywania w walce o byt, dzięki którym zajmują miejsce na górze, lub na dole hierarchii społecznej, tworząc kolejne elity lub masy (52).

Kościół to także elita katolicka, a więc ci spośród wiernych, którzy są najbardziej świadomi swojego powołania i misji w świecie, którzy potrafią spojrzeć na otaczający świat z szerszej perspektywy. Elita katolicka to nie tylko inteligencja katolicka, to na poziomie podstawowych wspólnot, elita parafii, liderzy i animatorzy różnego rodzaju wspólnot religijnych, ruchów i stowarzyszeń oraz organizacji katolickich. To także katolicy cieszący się autorytetem w środowisku społecznym.

W Polsce aktualnie elita katolicka jest słaba i rozproszona, niepewna swych racji, zagubiona, nie przygotowana do spełniania wszystkich zadan, które spełnić powinna w normalnym społeczeństwie i wolnym kraju. W Polsce kapłani często nie identyfikują się z elitą katolicką, przybierając co najwyżej postawę ich duszpasterzy, którzy mogą ją skupić na modlitewnych spotkaniach, podpowiedzieć temat do dyskusji, wygłosić homilię, czy konferencję o treściach mających w duchu wiary inspirować refleksję i działanie osób świeckich. Zajmując takie stanowisko polscy kapłani nie chcą i może już nie potrafią stanąć na czele choćby tam, gdzie brakuje przewodników, faktycznie przewodzić, angażować się wszędzie tam, gdzie kapłan pozostając w pełni kapłanem, może jako Polak i jako członek elity katolickiej zdziałać o wiele więcej niż świeccy.

Pierwszym zadaniem elity katolickiej w Polsce jest zintegrowanie się, umocnienie duchowe, moralne i liczebne. Spełniając to zadanie polska elita katolicka powinna pamiętać, że Kościół zajmie właściwe mu w Polsce miejsce jedynie przez jej działanie. To ona powinna inspirować takie przemiany polskich struktur społecznych, gospodarczych i politycznych, które prowadziłyby do budowania w naszym kraju modelu kościoła posoborowego jako wspólnoty wspólnot. Polska elita katolicka powinna też dążyć do opanowania tych struktur, kluczowych stanowisk, tak aby mogła mieć bezpośredni wpływ na życie publiczne w Polsce. Katolicy, którzy dążą do tego aby się stać elitą katolicką muszą uwolnić się od przeświadczenia, że formacja katolicka jest nudna i uniemożliwia jej zrozumienie. Muszą ujrzeć sens i głębię tej formacji, ujrzeć jej ścisłe związki z naszym człowieczeństwem i codziennym życiem. Teologia, filozofia, czy etyka, muszą być dla nich bardziej ciekawe niż beletrystyka, sensacja, czy sport. Formacja taka powinna być integralną i pełną oraz wciąż ubogacaną (53).

\section{Przypisy do rozdziału I - go}

1. J. Szmatka: Elementy mikrosocjologii, część II. Kraków 1992, s. 10-11.

2. Ibidem, s. 11.

3. Ibidem, s. 11. 
4. G. C. Homans: Social Behavior. Its Elementary Forms. New York. 1974.

5. H. Blumer: Symbolic Interactionism. Perspective and Method, New Jersey. 1969.

M. Kuhn: Major Trends in Symbolic Interaction Theory, w: Sociological Quarterly 5/64, s. 61-84.

6. G. Simmel: Socjologia, Warszawa 1975 r.

7. R. Bales, P. Slater: Role differentiation small decision making groups, Glencoe 1955, s. 259-306.

8. T. Parsons: Societies. New York, 1966.

9. J. Szmatka: op. cit. s. 12-15.

10. P. Rybicki: Struktura społecznego świata. Warszawa 1979 s. 235.

11. J. Szmatka: Studia Socjologiczne. 4/78, s. 29 "J. Szczepański twierdzi, że nie można należeć do narodu nie należąc do rodziny, małych grup i struktur pośrednich.”

12. A. Jasińska, M. Siemińska: Wzór osobowości, w: Oświata dorosłych 10/79.

13. R. Woźniak: Problemy struktur społecznych, a badania socjologiczne w: Roczniki Koszalińskie 1982, s. 8-17.

14. Ibidem, s. 21-23.

15. J. Szmatka: Małe struktury społeczne. Warszawa 1989, s. 19-21.

16. A Kłoskowska: Zagadnienie małych grup w socjologii. w: Przegląd Socjologiczny 12/58, s. 13-23.

17. J. Duke: The Principle of Emergence and Levels of Sociological Analysis. Bringham Young University, 1970.

18. M. Crozier: The Relationship between micro and macrosociology. w: Human Relations 25/72, s. 238-251.

19. P. Rybicki: op.cit.

20. R. Woźniak: op.cit. s. 19-20.

21. R. Woźniak: Rozwój i zmiana struktur społeczności miast portowych. w: Ziemie zachodnie i północne Polski tom. 4. Szczecin 1991, s. 148-151.

22. Ibidem, s. 152.

23. J. Szmatka: Elementy... op.cit. s. 25-28.

24. J. Szmatka: Jednostka i społeczeństwo. Warszawa 1980, s. 17-30.

25. J. Szmatka: Elementy... op.cit. 33-40.

26. J. Szacki: Historia myśli socjologicznej Warszawa 1983, tom. 2, s. 612-814.

27. J. Szmatka: Małe... op.cit. s. 334-344.

28. J. Sztumski: Społeczeństwo i wartości. Katowice 1992, s. 13-21.

29. I. Kant: Krytyka władzy sądzenia. Warszawa 1986, s. 381. 
30. S. Ossowski: Z zagadnień psychologii społecznej. w: Dzieła tom. 3, Warszawa 1967, s. 76-78.

31. J. Sztumski: op.cit. s. 19-21.

32. Was ist Religionssoziologie? w: Probleme der Religionssoziologie. Kolonia 1962.

33. H. Schelsky: Ist die Dauerreflektion institutionalisiebar? w: Zeitschrift für evangelische Ethik 4/57, s.154.

34. P. Smits: Schelsky's poging tot vernieuwing. w: Mens en Maat 3/61, s. 152.

35. B. Häring: Macht und Ohnmacht der Religion. Salzburg 1956, s. 18.

36. M. Yinger: Religion, Society and the Individual. New York 1957, s. 20.

37. M. Fürstenberg: Religionssoziologie. Tuebingen 1961, s. 1027

38. E. Vogt: Religion et Ideologie. w: Archives de Sociologie der religions 12/61, s. 80.

39. P. Berger: sekularyzacja, a problem wiarygodności religii. w: Socjologia religii. Kraków 1984, s. 374-384.

40. W. Piwowarski: Blaski i cienie polskiej religijności. w: Oblicza katolicyzmu w Polsce. Warszawa 1984, s. 10-23.

41. A. Morawska: Socjologia a odnowa. w: Znak 6/64, s. 722-733.

42. R. Towler: The Need for Certainty. London 1984, s. 4.

43. M. Libiszowska - Żółtkowska: Podstawy inteligencji wobec religii Warszawa 1991, s. $15-23$.

44. J. Mariański: Kierunki badań polskiej socjologii religii w latach osiemdziesiątych. w: Życie katolickie 9/89, s. 62-73.

45. J. Mariański. op.cit. w: Życie katolickie 11/89, s. 99-116.

46. J. Mariański. op. cit. w: Życie katolickie 1/90, s. 39-69.

47. G. Mosca: Historia doktryn politycznych od starożytności do nowych czasów. Warszawa 1939.

48. V. Pareto: Uczucia i działania, Warszawa 1994, s. 20-26.

49. R. Michels: Political Parties. Glencoe 1915.

50. C.W. Mills: Elita władzy. Warszawa 1961.

51. J. Higley: Elites in Australia. London 1979, s. 69.

52. J. Wasilewski: Współczesna wersja podejścia elitystycznego. w: Współczesne tendencje w socjologii empirycznej Kraków 1990, s. 65-84.

53. S. Krajski: Miejsce Kościoła i zadania dla elity katolickiej w Polsce. w: Emaus 14/92, s. 49 . 


\section{WSPÓLNOTA JAKO KATEGORIA SOCJOLOGICZNA I RELIGIJNA}

\section{1. Wspólnota jako kategoria socjologiczna}

\section{1. 1. Wspólnota według F. Toenniesa}

Między wolą jednego człowieka, a wolą innego człowieka występują wielorakie relacje, z których każda jest wzajemnym oddziaływaniem. Oddziaływania takie mogą prowadzić do zachowania lub zniszczenia ludzkiej woli czy ciała, czyli mogą je afirmować lub negować. Każdy taki stosunek reprezentuje jedność w wielości, albo wielość w jedności. Grupę utworzoną przez pozytywny stosunek, ujmowaną jako istota lub rzecz o spójnym działaniu wewnętrznym i zewnętrznym nazywamy związkiem. Sam ten stosunek, a zatem i związek rozumiany jest już jako realne i organiczne życie, co odpowiada istocie wspólnoty (Gemeinschaft), bądź jako twór idealny i mechaniczny odpowiada pojęciu stowarzyszenia (Gesellschaft) (1).

Współżycie poufałe, intymne, zamknięte w wąskim kręgu określane jest jako życie we wspólnocie. Stowarzyszenie to życie publiczne (światowe). We wspólnocie ze swymi najbliższymi znajduje się człowiek od chwili urodzin, związany $\mathrm{z}$ nią na dobro i zło, tymczasem w stosunki towarzyskie wchodzi się jak w coś obcego. Czasami ostrzega się młode osoby przed tzw. złym towarzystwem, podczas gdy zła wspólnota jest pojęciem sprzecznym z duchem języka. O stowarzyszeniu rodzinnym mogą mówić tylko prawnicy, natomiast wspólnotę rodzinną odczuwa każdy, kto w niej uczestniczył. Małżeństwo jest z założenia doskonałą wspólnotą życia (koinonia, communio, totus vitae), stowarzyszenie życia jest $\mathrm{w}$ tym przypadku sprzecznością samą $\mathrm{w}$ sobie. Towarzystwa można komuś dotrzymywać, natomiast wspólnoty nikt nikomu nie może dotrzymać. Wspólnota jest ponadto trwałą formą współżycia, stowarzyszenie tylko przejściową. Pierwszą można porównać do organizmu, drugą do maszyny. W myśl powyższych ustaleń cała teoria wspólnoty wychodzi od doskonałej jedności ludzkiej woli jako stanu pierwotnego lub naturalnego, który utrzymuje się mimo empirycznych podziałów. Ten stan pierwotny utrzymuje się $\mathrm{w}$ zależności od koniecznych i danych stosunków między odmiennie uwarunkowanymi jednostkami. Podłożem tych stosunków są ogólne zależności wynikające z urodzenia. Zależności te uwidaczniają się najbardziej w trzech typach tych stosunków: macierzyństwie, między mężczyzną a kobietą i w rodzeństwie. Jeżeli w każdym stosunku między współplemieńcami znajduje się przynajmniej zalążek wspólnoty, to wspomniane w tych stosunkach zalążki są najsilniejsze, lub najbardziej zdolne do rozwoju. Jeśli wszystkie stosunki okazują się wzajemnym służeniem oraz określaniem woli jednych przez wolę drugich, każdy może przedstawić równowagę sił, wtedy wszystko to co zapewnia przeciwwagę czyjejś woli musi być skompensowane intensywniejszym działaniem. W przypadku idealnym czerpaniu większych korzyści ze stosunku odpowiada cięższy rodzaj pracy wykonywanej na rzecz tego stosunku. Naturalna jedność jaką jest wspólnota krwi rozwija się i konkretyzuje we wspólnocie terytorium, której wyrazem jest współzamieszkiwanie. Ta z kolei przekształca się we wspólnotę ducha, czyli wspólne działanie w jednym kierunku, jednomyślność. Wspólnota ducha nakłada się na wspólnotę krwi i terytorium tworząc swoiście ludzki, najwyższy rodzaj wspólnoty.

Wszędzie, gdzie ludzie są ze sobą organicznie związani mocą swej woli, występuje taki czy inny typ wspólnoty, przy czym na gruncie wcześniejszego wykształca się późniejszy typ, jako względnie niezależny. Do najbardziej rozpowszechnionych typów należą: pokrewieństwo, sąsiedztwo i przyjaźń. Siedliskiem pokrewieństwa jest wspólny dom, ale wola i duch pokrewieństwa nie są uzależnione od jego ścian i bliskości przestrzennej. Jeśli są nawet żywe i silne jak w stosunkach rodzinnych, to żywią się nawet pamięcią i mimo 
oddalenia dają poczucie bliskości i współuczestnictwa w działaniu. Dlatego przeciętny człowiek najlepiej czuje się we własnym rodzinnym gronie (jest u siebie).

Sąsiedztwo jest charakterystyczne dla wspólnoty wiejskiej, gdzie bliskość zamieszkania, wspólne grunty, lub ich granice stwarzają liczne okazje styczności, powodują wzajemne przyzwyczajenia i intymną znajomość, zmuszają do wspólnej pracy. Podstawą tego rodzaju wspólnoty jest także współzamieszkiwanie. Może ono trwać także i bez niego, choć z większym trudem wymagając pomocy w częstszych spotkaniach.

Przyjaźń będąca warunkiem i skutkiem pracy i jednolitego sposobu myślenia jest niezależna od pokrewieństwa i sąsiedztwa. Aby mogła powstać i utrwalić się trzeba swobodnych i częstych kontaktów, o które najłatwiej w mieście. Bezpośrednie znaczenie ma w tym względzie boskość, ugruntowana i czczona przez ducha wspólnoty, gdyż ona nadaje przyjaźni żywą i trwała postać. Duchowa przyjaźń tworzy się jako rodzaje niewidzialnej osady, mistycznego miasta i żywego zgromadzenia, żywego mocą artystycznej intuicji oraz twórczej woli. Ludzie żyjący we wspólnocie należą do siebie i czerpią korzyści oraz posiadają i użytkują wspólne dobra. Wola posiadania i korzystania to wola opieki i obrony (2).

Każdy stosunek wspólnoty jest w założeniu, czy w swej najgłębszej istocie, wyższą i ogólniejszą jaźnią, na podobieństwo gatunku lub idei, z której wywodzą się jaźnie jednostkowe i ich wolność. Wspólnota, którą można ująć jako metafizyczny związek cielesny, krwi, ma od natury daną własną wolę i własną siłę do życia, a więc także i własne prawo w odniesieniu do woli swych członków. Wola jej członków okazuje się być modyfikacją i emanacją organicznej substancji ogółu (3).

Wspólnota w życiu rodzinnym oparta jest na zgodności. Człowiek uczestniczy w niej całą swoją skłonnością. Właściwym podmiotem takiej wspólnoty jest ludzkość. Życie na wsi jest oparte na obyczajach. Człowiek uczestniczy w nich całym swoim usposobieniem. Właściwym podmiotem jest tutaj społeczność. Życie w miastach pojmowane w kategorii wspólnoty może być oparte jedynie na religii. Człowiek uczestniczy w nim całym swoim sumieniem. Właściwym podmiotem jest tutaj Kościół jako wspólnota (4).

Rozróżnienie między wspólnotą, a stowarzyszeniem na stałe do nauki wprowadził $\mathrm{w}$ 1887 r. F. Toennies, w książce "Gemeinschaft und Gesellschaft" (Wspólnota i społeczność), mylnie przetłumaczono $\mathrm{w}$ polskim wydaniu dzieła: wspólnota i stowarzyszenie. Toennies wyszedł z rozróżnienia: wola podstawowa, która dojrzewa wewnątrz człowieka, w jego uczuciach i jego świadomości moralnej, powołując do życia podstawowe organizmy stowarzyszeniowe, takie jak wspólnoty krwi (rodzina, pokrewieństwo), wspólnoty przestrzenne (sąsiedztwo, wieś), wspólnoty duchowe (przyjaźń). Przez wspólnotę rozumie on taką rzeczywistość społeczną, która oparta jest na podstawowej wspólnej woli, społeczność zaś rodzi się w wyniku wspólnej woli wyboru. Wola podstawowa we wspólnocie przejawia się jako wierzenie, harmonia, religia, podczas gdy wola wyboru w społeczności przejawia sie $\mathrm{w}$ formie kontraktów, umów, statutów, konwencji. Przeciwstawienie ustalone przez Toenniesa zasługuje na kilka uwag krytycznych. Podstawowa idea, że podświadome i emocjonalne energie w człowieku są dobre, podczas gdy duch porządkujący wszystko, w jakiś sposób rozumny, jest podejrzany, nie jest do utrzymania. Ponadto autor przedstawia wspólnotę jako osadzoną na subiektywnym doświadczeniu, pomijając strukturę ontyczną (substancjalność i osobowość) człowieka jako założenie, podstawę i cel każdej wspólnoty. Podstawowe wyróżniki wspólnoty i społeczności nie polegają na stowarzyszeniu i wspólnym urzeczywistnieniu wartości, ale zakładają pewne uporządkowanie i kierownictwo (władzę), nawet jeśli nie możemy zaprzeczyć, iż rozróżnienie pomiędzy wspólnotą o charakterze 
bardziej osobowym, społecznością, zorganizowaną w sposób przeważnie utylitarystyczny, posiada wartość poznawczą (5).

Wspólnota wśród jestestw społecznych występuje wszędzie tam, gdzie mamy do czynienia ze stycznościami ludzkimi opartymi na wzajemnej zależności wynikającej z najgłębszych, najogólniejszych

potrzeb koniecznych człowieka. Tam gdzie mamy do czynienia ze stosunkami, w których ludzie działają zgodnie z pragnieniami i skłonnościami, miłością i przyzwyczajeniem, ucieleśnieniu uległa idea wspólnoty (6).

Jak powiada F. Toennies istnieją dwa rodzaje ludzkiej woli: arbitralna i organiczna. Wola organiczna powołuje do życia wspólnotę, natomiast wola arbitralna różne społeczności. Wspólnota łączy ludzi między sobą jako osobowości, społeczność, jako role przez tych ludzi podejmowane. Czynnikiem kontroli społecznej wspólnoty jest zwyczaj (tradycja), w społeczności - prawo. Wspólnota kieruje się w swoim postępowaniu wiarą, społeczność względem na opinię publiczną. Podstawą wspólnoty jest własność zbiorowa, społeczności pieniądz i własność prywatna. Koncepcja F. Toenniesa miała sens historiozoficzny. Zmierzała do pokazania, jakim zmianom ulegają społeczeństwa europejskie pod wpływem rozwijającego się kapitalizmu, zwracając uwagę na rozkład dawnych więzów wspólnotowych i kształtowanie się stosunków społecznych, w których ludzie traktują siebie jako środki do osiągnięcia swych prywatnych celów. Koncepcja F. Toenniesa ma też charakter utylitarystyczny, ukazując upadek w świecie wolnego rynku pewnych wartości społecznych i zmierzał do wykazania, że żaden stosunek społeczny nie może być trwały bez obecności w nim elementu wspólnotowego. Trzeci i najważniejszy element koncepcji wspomnianego autora ma charakter teoretyczny, który miał dostarczyć naukom społecznym uniwersalnych kategorii, nadających się do analizy wszystkich zjawisk życia społecznego (7).

\section{1. 2. Inne ujęcia wspólnoty jako kategorii socjologicznej}

Już w socjologii Platona na pierwszym miejscu pozostawała nie wyzwolona jednostka ludzka, lecz trwała wspólnota, która ma solidniejsze podstawy niż wola jednostek i cel wyższy niż uczynienie jednostek szczęśliwymi (8).

Arystoteles twierdził, że każdy człowiek ma sobie właściwe przeznaczenie, którego realizację zapewnia dopiero związek z innymi. Przez takie połączenie istot, które bez siebie istnieć nie mogą, powstaje najpierw rodzina, wspólnota rodzin, czy wreszcie gmina. Pełna wspólnota powstała z większej ilości gmin, która niejako osiągnęła już kres wszechstronnej samowystarczalności jest państwem (9).

Ludzka wspólnota jakiej szukał Seneka nie była, dla odmiany, wspólnotą polityczną. Było to raczej społeczeństwo niż państwo. Więzy wspólnoty były raczej moralne i religijne, niż prawno - polityczne (10).

Dla myślicieli wczesnochrześcijańskich wspólnota jawiła się przede wszystkim w kategoriach wiary, jako doskonałe zjednoczenie, wobec którego wszelkie inne związki traciły jakiekolwiek głębsze znaczenie, skupiały się bowiem na sprawach doczesnych, podczas, gdy jedność w Chrystusie otwierała drogę do wiecznego zbawienia. Tylko do wspólnoty wartości stosowała się teraz analogia organicystyczna, dawniej stosowana wobec społeczeństwa jako całości (11).

Fundamentem Augustiańskiej socjologii było przekonanie, iż wspólnotą wartości jest w istocie każde społeczeństwo. Dwóm przeciwstawnym systemom wartości jakim hołdują państwo i Kościół odpowiadają dwa rodzaje ładu społecznego - konsensusowy i konfliktowy (12). 
Ośrodkiem średniowiecznego schematu rzeczy była wspólnotowość i przynależność. Całość porządku społecznego była pojmowana jako rodzaj communitas communitatum (wspólnota wspólnot) i niezależnie od tego, czy chodziło o klasztor, gildię, uniwersytet, stan rycerski lub rodzinę patriarchalną, obowiązkiem należącej do takiej wspólnoty jednostki było jej służyć (13).

Nowe wyobrażenie wspólnoty jakie przyniósł ze sobą okres Odrodzenia stanowiło prefigurację społeczeństwa jako wspólnoty jednostek wolnych i równych kierujących się w swoim postępowaniu własnym sumieniem, nie zaś względem na takie, czy inne autorytety (14).

W okresie Oświecenia w Niemczech duży wpływ miały poglądy organicystyczne. Organicyzm w wydaniu J. Herdera zakładał, że społeczeństwo jest dla jednostki ludzkiej stanem naturalnym. Od chwili narodzin jednostka jest wtopiona w jakąś wspólnotę (rodzinę, plemię, naród). Najważniejszą wspólnotą jest według Herdera naród (Volk). Istotą państwa jest u niego nie suwerenna władza, lecz wspólnota ludzka, która wyłania taką organizację polityczną, jakiej potrzebuje (15).

Wspólnota w poglądach socjalistów utopijnych miała przede wszystkim konotację wspólnoty posiadania, ideału społeczeństwa bez własności prywatnej (16).

Twierdzili oni, że wspólnota jest formą zrzeszenia najnaturalniejszą i najdoskonalszą. Równocześnie jest jedynym i niezawodnym sposobem pokonywania wszystkich przeszkód utrudniających rozwój społeczeństwa, zapewnia bowiem właściwe ujęcie wszystkich namiętności i zaspokojenie wszystkich potrzeb (17).

W filozofii G.F. Hegla wspólnotą należałoby nazwać państwo, podkreślając jednak, że ta wizja zakłada wysoko rozwiniętą świadomość (rozum zamiast przesądu), autonomię jednostek jako świadomych podmiotów oraz urzeczywistnianie ich wolności (o ile nie jest ona samowolą lecz wolnością rozumną) (18).

Twórca pragmatyzmu społecznego J. Dewey zauważył, że związek między słowami wspólny (common), wspólnota (community) i wspólne dzielenie się (communication) jest czymś więcej niż tylko związkiem lingwistycznym. Ludzie żyją dzięki temu, co jest ich wspólną własnością. Na to zaś co ludziom musi być wspólne, by mogli tworzyć wspólnotę składają się poglądy, aspiracje, wiedza tzn. jednakowe rozumienie pewnych spraw, wspólne nastawienie (jak to określają socjologowie) (19).

Wizja społeczeństwa jako wspólnoty myśli i uczuć jest równie stara jak myśl społeczna (Platon, Arystoteles) i większość socjologów przywiązywała do niej ogromne znaczenie (20).

Oryginalność Deweya polegała na przeniesieniu punktu ciężkości z rozważań o consensusie jako atrybucie społeczeństwa nad rozważania o procesie powstawania wspólnoty myśli i uczuć w toku interakcji między jednostkami.

A. Comte'a i E. Durkheima wspólnota interesowała jako coś danego, Deweya jako coś tworzonego. Nie społeczeństwo kształtuje jednostki, lecz jednostki kształtują się same w toku wzajemnych interakcji, dzięki którym społeczeństwo może istnieć (21).

Amerykański przedstawiciel szkoły pragmatycznej C. Cooley zwrócił szczególną uwagę na związek grup pierwotnych z procesem stawania się wspólnot. Cooley wyróżnił trzy rodzaje grup pierwotnych: rodzinę, dziecięcą grupę zabawową oraz wspólnotę sąsiedzką. Człowiek żyje według niego z poczuciem grupowej jedności i wspólnoty grupowego "my". W tym właśnie poczuciu znajduje jednostka główne cele swego działania. najważniejszy ideał wyrastający z grup pierwotnych, to ideał moralnej wspólnoty. W czasach Cooleya do najbardziej żywotnych przejawów takiej wspólnoty należały: demokracja i chrześcijaństwo. Powołanie takiego ładu wspólnotowego jest historycznym zadaniem całej ludzkości (22). 
Max Scheler w swojej pracy "Istota i formy sympatii” zwraca uwagę na wspólnotę jako jeden z możliwych obiektów miłości jej członków. Moralna wartość jakiejkolwiek wspólnoty powinna być mierzona określonym ładunkiem włożonej w nią miłości (23).

Znany niemiecki socjolog religii J. Wach analizując formy w jakich przejawia się każde zjawisko religijne wyodrębnił jego wyraz teoretyczny (doktrynę), wyraz praktyczny (kult), oraz wyraz społeczny (wspólnotę). Uduchowione pojęcie wspólnoty, która ma być realizowana w ramach grupy tradycyjnej, może powstać w celu zjednoczenia tych, którzy w przeciwnym wypadku poszukiwaliby doskonałości niezależnie (paralelizm spontaniczności indywidualnych), bądź też ideał ów może prowadzić do prób ustanowienia "prawdziwej" społeczności wiary, niezależnie od wszelkich grup istniejących. Socjolog religii winien klasyfikować i badać starannie różne typologiczne struktury organizacyjne, wynikające z rozbieżnych koncepcji wspólnoty. Winien śledzić ich rozwój historyczny niezależnie od badania różnych form braterstwa (fellowship), pojęcia występującego we wszystkich epokach i we wszystkich częściach świata (24).

Jednym z czynników wpływających na powstawanie wspólnot jest konwersja. W tym rozumieniu jest postrzegana jako proces tworzenia czynnych stosunków międzyludzkich, aktywnie tworzonych i podtrzymywanych, odmiennych od konwencjonalnych stosunków. Konwersja jest tu procesem uwspólnotowienia, łączenia oddzielonych społecznie ludzi, odseparowanych od siebie przez podział pracy, własności, różnice płci itp. Jako wspólnota jest brana pod uwagę polska wersja angielskiego słowa communion, którym posługiwali się tylko nieliczni socjologowie. Chodzi tu bowiem o pojęcie odmienne od community, czy Gemeinschaft Toenniesa. Tacy autorzy, jak F. Znaniecki, H. Schmalenbach, czy V. Turner próbowali przezwyciężyć dychotomię form organizacji społecznej, F. Znaniecki obok więzi naturalnych Gemeischaft, $\mathrm{z}$ jakimi mamy do czynienia w przypadku więzi rodzinnej, sąsiedzkiej, czy etnicznej, wyróżnił więź synergetyczną. O ile grupy typu stowarzyszeniowego, czy wspólnotowego nie są zdolne do podjęcia ryzyka zupełnie nowych przedsięwzięć, nowych celów i sposobów współdziałania, to wspólnoty synergetyczne nie mają utylitarnej podstawy. Wspólnoty synergetyczne są oparte na tendencji do rozwijania wspólnoty woli, wspólnych działań i są zdolne do ryzykownych nowych działań. J. Wach słusznie zauważa, że wspólnota duchowa nie jest prostą kontynuacją więzi naturalnych. Religijne podtrzymywane więzi społeczne w takim przypadku przerywają więzi naturalne. Wspólnota synergetyczna w najprostszej formie może realizować się między dwojgiem osób, które wchodzą w interakcje, zmniejszając różnice między sferami wartości, będących przedmiotem aktywnego zainteresowania każdej z nich. Dążą one wówczas do coraz szerszej interpretacji swoich obszarów aktywnego doświadczenia, a więc do społecznego zjednoczenia się. Wspólnotę działania musi poprzedzać wspólnota doświadczenia. Jest ona możliwa dzięki komunikacji, która czyni doświadczenia wspólnymi. Konieczna jest też wspólnota uczuć wobec doświadczanych wartości. Podstawą wspólnoty sympatetycznej jest podzielanie postaw, dzięki zgodnej ocenie ważności aksjologicznej doświadczanych obiektów w odniesieniu do tego samego systemu wartości. Wtedy jest możliwa wspólnota synergetyczna, czyli podzielanie wspólnych dążeń do działania w ramach realizacji wspólnego obiektywnego zamiaru. Wspólnota synergetyczna różni się od zwykłego kolektywnego działania, ponieważ motywy i zamiary działających muszą tu być jednakowo oparte na wspólnych doświadczeniach i wartościowaniach. Współdziałanie uważane jest ponadto za obowiązek moralny wobec grupy. Wspólnota communitas najlepiej się realizuje, gdy jej uczestnicy pozostają w sytuacji liminalnej do struktur społecznych, żyjąc na ich obrzeżu. Nie bez przyczyny przejście w ruchach monastycznych, czy zakonnych wymagało wyzbycia się wszelkich oznak statusu "bycia w świecie" (przykład reguły św. Franciszka - 
wyzbycie się wszystkiego). Wspólnota to kolektywnie rozszerzone relacje typu "my". Wspólnotę charakteryzuje kolektywne zainteresowanie wartościami, w których wszakże zachowane pozostaje zainteresowanie indywidualne. W przypadku wspólnoty uczucia są konstytutywne i towarzyszą jej wyłanianiu się. Wspólnota jest budowana na aktualnych świadomych doświadczeniach i uczuciach, które nie są wyłącznie subiektywne, lecz intencjonalnie skierowane ku wspólnym obiektom. Wspólnota w pełni istnieje, gdy pojawia się uczucie wspólnotowości, wyłania się z ekscytacji i wzajemnego pobudzania o charakterze kolistej interakcji, jak mówili R. Park i H. Blummer. Wspólnota konstytuuje się, gdy pojawia się communio uczuć jako fakt społeczny. Chociaż dąży do objęcia osoby jako konkretnego indywiduum w jego całości, jest tylko pewną formą społecznego istnienia osób, społecznego ich uczestnictwa. Wspólnoty normatywne rozwijają się jako realizacja dawniejszych modeli utopijnych, lub tworzą nowe modele społeczności zorganizowanych jako wspólnoty egzystencjalne. Wspólnota ta ma więc aspekt egzystencjalny, normatywny i ideologiczny (25).

$\mathrm{Na}$ ogół doceniana jest wartość włączenia się człowieka w większe wspólnoty, jako szansa rozwoju osobowego. Szansą jaką daje wspólnota ludzka, jest bliska tej jaką daje rodzina, z tym uzupełnieniem, że życie we wspólnocie, od chwili wejścia a nawet poszukiwania, rozgrywa się w świetle świadomości i jego przebieg, etapy, kryzysy można zaobserwować znacznie dokładniej niż w rodzinie (26).

\section{1. 3. Typologia wspólnot}

Z faktu, iż przyczyną formalną społeczeństwa jest dobro wspólne można wyprowadzić wniosek, że tyle jest różnych wspólnot, ile różnych rodzajów dobra wspólnego. Dobro wspólne jako zespół warunków mających się przyczynić do udoskonalenia wszystkich ludzi wchodzących w skład społeczności winno być rozważane w potrójnym odniesieniu: do dobra jako takiego (dobro wspólne realizacją idei dobra), dobro wspólne przyczynia się do doskonalenia osoby (odpowiada dążeniom i potrzebom człowieka), jako zespół warunków doskonalenia człowieka (jako element środowiska domaga się jego przemiany i doskonalenia się). W miarę historycznego rozwoju rozszerza się zakres środowiska, w którym może być realizowane dobro wspólne i w związku z tym ludzie tworzą wspólnoty o coraz to szerszym zasięgu, nie rezygnując za życia i działania we wspólnotach mniejszych. Najstarsze i najbardziej angażujące całą osobowość człowieka są tzw. wspólnoty podstawowe, w którym poszczególne osoby ludzkie zaspokajają swoje codzienne, najbardziej elementarne potrzeby fizyczne i psychiczne, począwszy od potrzeb gospodarczych, poprzez potrzebę asocjacji, kontroli, zdobywania podstawowych wartości kulturowych, manifestacji itp. aż po potrzeby religijne. Klasyczną wspólnotą podstawową jest oczywiście rodzina, która jest najstarszą i najpełniej angażującą człowieka wspólnotą. Choć liczebnie niewielka, nie jest ona wspólnotą prostą lecz wielorako kombinowaną. Wyraża się to $\mathrm{w}$ różnych rodzajach wzajemnych styczności i stosunków oraz więzi i wzajemnych funkcji. Cechami, które predysponują w szczególny sposób rodzinę do odegrania roli wspólnoty podstawowej jest jej intymność i zarazem otwartość. Intymność polega na zaangażowaniu we współżyciu całej osobowości człowieka, idąc daleko w jej głąb. Otwartość występuje tutaj nie w sensie socjologicznym lecz funkcjonalnym. Rodzina przygotowuje swoich członków do życia w szerszej społeczności.

Obok rodziny stosunkowo często (nie tylko w zasięgu kultury chrześcijańskiej) często spotykanymi wspólnotami podstawowymi są klasztory. Widzi się w nich przede wszystkim wspólnoty religijne, ale są one także, a może nawet w tym samym stopniu wspólnotami życia codziennego, realizującymi szeroki wachlarz celów, od religijnych po gospodarcze. 
Intymność wspólnoty klasztornej opiera się na przesłankach religijnych, a jej otwartość polega na wychodzeniu klasztoru na zewnątrz nie po to by pozostać w świecie, lecz byvgo zmieniać i mu służyć.

Obok tych dwóch rodzajów wspólnot podstawowych, obejmujących niejako całe życie człowieka istnieje wiele różnego rodzaju wspólnot małych, które stanowią ich uzupełnienie lub z nimi konkurują. Pomimo, że nazywa się je wspólnotami podstawowymi- są one raczej czymś pośrednim między wspólnotą a stowarzyszeniem, na tym podstawowym poziomie uspołecznienia. Grupy te odgrywają niemałą rolę w kształtowaniu postaw społecznych ludzi i dlatego cieszą się dużym zainteresowaniem, bowiem w pewnym zakresie uzupełniają rodzinę, lub konkurują $\mathrm{z}$ nią i dlatego we wszystkich rozważaniach na temat wspólnot podstawowych ich obecność nie może być pomijana. Podobnie zresztą jak grupy podstawowe mają one także swoje znaczenie dla życia wspólnotowego na wyższym szczeblu.

Kolejnym rodzajem wspólnot są tzw. wspólnoty środowiskowe, czyli społeczności kształtujące się i obejmujące życie ludzi na szczeblu i w wymiarach środowiska. Istnieją trzy typy takich wspólnot: wspólnoty sąsiedzkie, wspólnoty zakładów pracy i wspólnoty regionalne. Wspólnoty sąsiedzkie mają przede wszystkim charakter wzajemnej pomocy, choć niegdyś odgrywały rolę systemu współpracy gospodarczej. Drugi typ wspólnot oparty na środowisku zakładu pracy bierze pod uwagę fakt i potrzebę współdziałania we współczesnym systemie organizacji nie tylko działalności produkcyjnej, ale całości życia gospodarczego. Wspólnoty regionalne mają charakter kulturowy. Ich znaczenie zmniejszyło się wskutek umasowienia kultury przez środki społecznego przekazu.

Trzeci rodzaj wspólnoty rozciąga się na całą ludzkość. Wspólnota ludzkości obejmuje wszystkich ludzi istniejących aktualnie na naszym globie, a jej podmiotami są zarówno poszczególni ludzie, jak i, poszczególne ludy, organizmy społeczne istniejące w skali narodowej i ponadnarodowej. Dobrem wspólnym tak pojmowanej wspólnoty jest pokój i możliwość rozwoju (27).

Wracając do kwestii rodziny jako wspólnoty nadmienić należy, iż wypływa ona $\mathrm{z}$ natury ludzkiej, a nie jest dziełem umowy społecznej. U jej podstaw leży naturalny podział ludzi na dwie płcie zróżnicowanie wiekowe, popędy seksualne, instynkt ojcowski i macierzyński. Rodzina wymaga od swoich członków integralnego zespolenia celów i dążeń, podejmowanych dobrowolnie, a jednocześnie z poczuciem wewnętrznej konieczności, rządzi się miłością a nie prawem, które ma tu zastosowanie jedynie jako konsekwencja i obrona miłości. Wspólnota rodzinna daje swoim członkom wiele radości i przyjemności istotnie wspólnotowych, zupełnie rożnych od radości gwarantowanych przez inne grupy społeczne. Uczucia i dążenia swoich członków uspołecznia tak, iż czują się oni zespoleni w dążeniu do celu i gotowi są zrezygnować ze swobody indywidualnej i wolności na rzecz grupy rodzinnej (28).

Więź powstająca $w$ ramach wykonywanej pracy coraz wyraźniej sytuuje się na czele więzi społecznych. Zastępuje ona w wielu rejonach współczesnego świata słabnącą więź wspólnoty geograficznej, terytorialnej, czy sąsiedzkiej. Rozwój techniczny rozbijając dotychczasowe rodzaje integracji społecznej podniósł jednocześnie znaczenie pracy jako czynnika nowej integracji. Od wspólnoty ludzi solidarnych, ukształtowanej w ramach wykonywanej pracy prowadzi droga do miłości towarzyszy pracy, zaś później tych, dla których się daną pracę wykonuje (29).

Szczególnym rodzajem wspólnoty jest analizowana przez K. Żygulskiego wspólnota śmiechu, czyli wspólnota połączona szczególną więzią społeczną, nieraz o charakterze trwałym, a nawet sformalizowanym. Jest to zarazem wspólnota kulturowa, podobna do tej jaką wytwarza język. Z historii różnych ustrojów, systemów, władców, a zwłaszcza despotów 
wiadomo, że szły $\mathrm{w}$ zapomnienie różne, nieraz wielkie winy tym, którzy potrafili w stosownej chwili wytworzyć specyficzną wspólnotę śmiechu (30).

Każde spotkanie może ukonstytuować wspólnotę rozumianą jako związek dwóch przynajmniej osób, będący wynikiem przedłużenia postawy rodzącej się w spotkaniu. O ile podczas spotkania dochodzi do związku dwóch osób, o tyle wspólnota może skupić większą ich ilość, z których część może przystąpić do niej bez uprzedniego przeżycia spotkania, ale w wyniku jego zaistnienia dla bliskich im ludzi. Można wtedy mówić o wspólnocie zapośredniczonej. Wspólnota jest drugim etapem (po spotkaniu) procesu zespalania się ludzi w osobowych związkach powstających na gruncie odczucia jedności i opartych na zaufaniu do bliźnich. Jest też efektem rozświetlenia aksjologiczno-moralnych horyzontów w spotkaniu, nie tylko dla jego uczestników, ale i dla wszystkich, którzy chcą się poddać takowemu rozświetleniu. Wspólnota stanowi naturalną kontynuację postawy wykształconej podczas spotkania. Nie ma ona innego celu, jak wewnętrzne doskonalenie się jej członków, którego zewnętrznymi objawami mogą być pozytywne zmiany w społecznej strukturze. Wyjść poza siebie, rozumieć (zobaczyć się z punktu widzenia drugiej osoby), wziąć na siebie zadania drugiej osoby, dawać (ofiara bez miary i oczekiwania na rewanż) oraz być wiernym to według E. Mouniera pięć aktów mających doprowadzić do wspólnoty osób. Prawdziwą wspólnotę tworzą ludzie zaangażowani w sprawy świata (choćby małego wycinka) i często dopiero żyjąc we wspólnocie mogą oni ujawnić wszystkie swe możliwości. Osobowe zespolenie, którego pierwszym aktem jest spotkanie, a drugim wspólnota nie może niszczyć wolności osoby, która stanowi jej fundament. Podjęcie trudu bycia we wspólnocie jest pewną formą zawierzenia swej wolności drugiemu człowiekowi, potraktowaniu go jako tego, który nie nadużyje zaufania i w pełni doceni ofiarowaną mu wolność. Wolność osoby pozwala nam na wycofanie się ze wspólnoty kiedy odczujemy wygasanie więzi z jej członkami. Spotkanie z Bogiem we wspólnotach typu religijnego doprowadza do wspólnoty przeżywanej przez człowieka z innymi ludźmi, ale odczuwanej jako zapośredniczonej przez Boga. Nadaje to jej wyjątkowy charakter wspólnoty, w której jest obecna hic et nunc jej Najważniejsza Osoba. Wspólnoty tego typu mogą tworzyć się wokół człowieka, który doznawszy spotkania z Bogiem przenosi swój stan duchowy na innych ludzi w fenomenie spotkania z nimi. Gminy wczesnochrześcijańskie czy klasztory Wschodu są przykładem takich wspólnot (31).

\section{1. 4. Elementy konstytutywne wspólnoty}

Wspólnota rozumiana jako communio personarum (wspólnota osób) wyraża treść bogatszą i głębszą niż socjalizacja. Chodzi tu bowiem o ufne, całkowicie pozbawione interesowności zawierzenie i niejako powierzenie się wielkiej sprawie podmiotowości i godności ściśle osobowej, z której płyną wszelkie określone naturą uprawnienia. W szczególności chodziłoby o "położenie sobie na sercu" dobra innych osób właśnie jako innych, o najgłębszą i najszlachetniejszą $\mathrm{z}$ nimi solidarność, a więc nie o czysto sprawiedliwościowe minimum, ale optimum miłowania. W myśli społecznej ostatnich papieży, a zwłaszcza Jana Pawła II, kultura jest nade wszystko potwierdzeniem człowieczeństwa, realizowanym we wspólnocie. Ujawnia ona bowiem aksjologiczny status osoby. Godność człowieka jako osoby jest wartością trwałą i na tej zasadzie staje się ona miarodajna dla naszego postępowania zawsze i powszechnie. Postępowanie to uobecnia ją, albo jej nie uobecnia, może zostać nawet przez kogoś totalnie zanegowana w życiowej praktyce, w postawach, czy konkretnych odniesieniach do kogoś innego lub do siebie samego. Byłoby to równoznaczne z negacją własnego niezamiennego miejsca we wspólnocie (communio) osób, z przyjęciem takiego usposobienia, jakie już nie może odpowiadać tej wspólnocie (32). 
W procesie budowania wspólnoty najpierw stosunki układają się na zasadzie "ja - wy". Jednostka dostrzega w przynależności do wspólnoty i w niej samej dobro, jednak nie jest pewna akceptacji. Okres ten można nazwać kandydackim. Udziałem kandydata jest niepewność czy zostanie zaakceptowany. Przez jego zachowanie przewija się demonstracja zachowania wymaganego w danej wspólnocie. Oczywiście od rodzaju wspólnoty zależy, czy przyjęte dla uzyskania akceptacji cechy stanowią rozwój czy regres. Okresowi temu towarzyszy wzrost krytycyzmu wobec własnej osoby. Uzyskanie aprobaty i włączenie się we wspólnotę przynosi nowy okres: konfrontację oczekiwań ze spełnieniem. Celem tego okresu jest zaakceptowanie wspólnoty mimo pewnych rozczarowań i powstania postawy "my" w stosunku do całości, jaką staje się "ja i wy". Jednak nawet mocno ugruntowane "my" nie stanowi punktu dojścia w rozwoju wspólnoty. Bowiem "ja” pozostaje wrażliwe i czujne, szczególnie w najważniejszych momentach życia: chorobie obniżającej sprawność, w sytuacji konfliktowej, w subiektywnym poczuciu doznanej niesprawiedliwości, w ocenie, odmowie przyjęcia wnoszonych propozycji zmian istotnych dla życia całej wspólnoty. Taki punkt kryzysowy stanowi jakby rozstaje dróg, z których jedna i tylko jedna, którą charakteryzuje postawa "ja dla was" stanowi etap rozwojowy, ale nie ostateczny. Przeciwna tej, postawa pretensji "wy dla mnie", jest drogą regresji, zawiera bowiem z reguły elementy oskarżenia dla wspólnoty, lub jej członków. W postawie "ja dla was" zostaje zwyciężone "ja”, wspólnota jeszcze raz zostaje potwierdzona w nowym "my", gdzie rola "ja" określona jest jako uznanie wartości i podporządkowanie. "My" uzyskuje rangę nadrzędną, uzasadniającą nasze oddanie na służbę wspólnocie. To nowe przeżycie "my" jest dojrzalsze, ale i ono może podlegać zakwestionowaniu. Ono samo nie jest celem samym w sobie, , lecz domaga się określenia sensu wspólnoty, który musi istnieć dla czegoś (lub kogoś) poza sobą, jeśli nie ma być tylko towarzystwem wzajemnej adoracji, czy też spółdzielnią (wspólnotą interesów). To zakwestionowanie domaga się rzeczywistego uświadomienia i przyjęcia dla celu istnienia każdej wspólnoty postawy "my dla innych". Nawet jeśli cel wspólnoty i jej założenia są znane od początku ,jeśli nawet stanowią istotny motyw kandydowania to więź emocjonalna ze wspólnotą, wrastanie w nią przebiega poprzez wszystkie te etapy i żadnego z nich nie można ominąć. Czasami trwa to latami, czasami całe życie (33).

\section{1. 5. Internalizacja w procesie budowania wspólnoty}

Człowiek jest nie tylko istotą biologiczno - społeczną, czy też racjonalno-emocjonalną, ale również, ale również aksjologiczną, czyli taką, która tworzy i wybiera sobie $\mathrm{z}$ otaczającego ją świata określone wartości oraz kieruje się nimi w swoich zachowaniach. Oczywiście, im większe społeczne zaangażowanie społeczne człowieka, w tym większej liczbie systemów społecznych się on znajduje, stykając się z rozmaitymi wartościami. Jedne z nich powtarzają się, będąc wspólne dla określonego kręgu kultury, bądź osób, inne pozostają specyficzne dla celów danego systemu społecznego. Biorąc to pod uwagę możemy wyróżnić wartości podstawowe (dla każdego systemu społecznego), wtórne (wynikające z podstawowych, będące ich rozwinięciem lub konkretyzacją) indywidualne (prywatne stanowiące twór poszczególnych jednostek ludzkich). Oczywiście akceptacja takiej czy innej wartości stanowi pewne minimum, które nie pociąga za sobą ich realizacji. Uznawanie tych wartości warunkuje jednak uczestnictwo w danym systemie społecznym (wspólnocie). Urzeczywistnienie owych wartości w pełnym zakresie świadczy o maksymalnej identyfikacji danego człowieka $\mathrm{z}$ określonym systemem społecznym. Poszczególne systemy społeczne skłaniają ludzi, którzy w nich żyją do internalizacji określonych wartości, stanowiących ich część składową, czyli do przyjmowania owych wartości za własne. Wartości takie są przekazywane poprzez cele i dążenia danego systemu społecznego, obowiązujące w nim 
normy moralne regulujące współżycie wewnątrz systemu i poza systemem, przyjęte w obrębie systemu wzorce osobowe, uznawane koncepcje światopoglądowe, społeczne i polityczne, lansowany styl życia.

Zastanawiając się nad procesem internalizacji M. Gołaszewska doszła do wniosku, że jest to proces o następującej strukturze:

- informacja (o wartościach i warunkach ich realizacji)

- transformacja (tłumaczenie na własny język odbiorcy informacji),

- zaangażowanie (akceptacja lub odrzucenie, obojętność lub wrogość),

- inkluzja (inicjowanie przez akt akceptacji wartości, włączenie jej w osobiście uznawany system),

- dynamizacja (zmiany we własnej osobowości, wynikające z uznania danej wartości konwersja).

W procesie wpływu wartości na zachowanie ludzi można wyróżnić trzy etapy:

- percepcji wartości,

- przeobrażania się pod wpływem pojętych wartości, przekonań i opinii,

- kształtowanie określonych postaw.

Pierwszy etap wiąże się ze spostrzeżeniem istnienia określonych wartości oraz ze zrozumieniem i oceną ich przydatności dla danego człowieka. Czynnikiem sprzyjającym poznaniu wartości może być działalność innych ludzi prezentujących sobą lub propagujących jakieś wartości, własne poszukiwania motywacji dla zamierzonych działań, moralne potrzeby.

Drugi etap łączy się z kształtowaniem relacji uczuciowych i refleksyjnych do danych wartości. Podane wartości w miarę przyswajania przez konkretnego człowieka zaczynają oddziaływać na jego myślenie, znajdują swoje odbicie w poglądach i przekonaniach.

Trzeci etap dotyczy procesu, w czasie którego, pod wpływem określonych wartości zaczynają kształtować się postawy ludzi odpowiadające tymże wartościom, czyli pewne orientacje zgodne z nimi. Dopiero od momentu pojawienia się określonych zachowań ludzi, które wskazują na istnienie związków z przyjętymi przez nich wartościami, $\mathrm{z}$ wysokim prawdopodobieństwem przyjąć trzeba, że znajdują się oni pod wpływem tychże wartości (34).

\section{1. 6. Wartości, a zachowanie czlonków wspólnoty}

Wartości stają się swoistymi moralnymi bodźcami, skłaniającymi ludzi do określonych zachowań. Poprzez lansowanie określonych wartości można zachęcać ludzi do tych zachowań, które uważa się za pożądane. Mechanizm kształtowania się zachowań człowieka, pod wpływem różnorodnych bodźców był przedmiotem szczególnego zainteresowania behawiorystów (35).

Nazywali oni bodźce zmiennymi niezależnymi, a wywołane przez nie reakcje zmiennymi zależnymi. Ich zdaniem wszelkie reakcje człowieka, czyli jego zachowanie są po prostu funkcją bodźców. Zwiększeniu stopnia integracji dowolnego systemu społecznego bardziej sprzyjają motywacje prospołeczne, niż aspołeczne, czy antyspołeczne. Nawet najbardziej prymitywne potrzeby ludzkie nie były i nie są nigdzie jednakowe, ani też jednakowo wartościowane. W społeczeństwach żyjących we wspólnocie pierwotnej były one zależne od statusu danej osoby, wieku płci, a niekiedy posiadanej umiejętności. Potrzeby nabyte w ciągu życia osobniczego są społecznie uwarunkowane, a indywidualnie 
kształtowane. Wartości wynikają ale i wpływają w istotny sposób na procesy motywacyjne i zachowania ludzkie (36).

Przy analizowaniu wartości i ich odniesienia do procesu budowania wspólnoty nie należy zapominać, iż istnieją one niezależnie od poznających je podmiotów, ale są też przez nie kreowane. Większość socjologicznych definicji wartości zredukować można według F. Adlera do czterech podstawowych typów:

- wartości są absolutami w umyśle Boga jako wieczne idee,

- wartości tkwią w przedmiotach materialnych, czy też niematerialnych jako cechy pożądane, mające zdolność zaspokajania potrzeb,

- wartości tkwią w człowieku, w jego potrzebach biologicznych, lub w jego umyśle,

- wartości są tożsame $\mathrm{z}$ werbalnymi i pozawerbalnymi zachowaniami zewnętrznymi ludzi (37).

M. Misztal w badaniach nad wartościami stwierdza, że dla socjologa wartościami, które powinny go zainteresować są przede wszystkim reguły zachowania zabezpieczające konformizm jednostki w stosunku do ustalonego działania, pełniące w życiu społecznym funkcję kontrolną (38). Reguły te to zwyczaje, obrzędy, normy prawne, normy wychowania, przekonania itp. (39).

Z przeżywaniem wartości wiąże się przeżycie pewnego ideału (optimum) pewnej wartości. Każda urzeczywistniona wartość uczestniczy w tym ideale, lecz się z nim nie utożsamia.

Moralność obejmuje człowieka jako podmiot i przedmiot. Przez tę relację człowiek moralnie jest zespolony z innymi i to wszystko co odnosi się do niego (jako wartości) odnosi się także w odpowiedni sposób do innych. Fundamentem moralności jest podstawowa i pierwotna godność osoby. Jej treścią od strony pozytywnej jest afirmacja (miłość), działanie na rzecz dobra wspólnoty. W tej zasadniczej łączności “ja-ty-my”, tkwi sens afirmacji (40).

\section{1. 7. Autorytet i prestiż we wspólnocie}

W każdej społeczności ludzkiej są uznawane i szanowane określone wartości, zarówno racjonalne jak i irracjonalne. Racjonalnymi nazywamy te, które są rzeczywiście osiągalne w danych warunkach społecznych, przez całą społeczność lub jej poszczególnych osobników. Irracjonalnymi te, które $\mathrm{w}$ danych warunkach są nieosiągalne $\mathrm{w}$ identycznym zakresie. Ludzie reprezentujący w skali nieprzeciętnej wartości cenione w danej społeczności, cieszą się szczególnym uznaniem ze strony innych osób tworzących społeczność. To szczególnie uznanie jest źródłem autorytetu i prestiżu. Autorytet i prestiż to dwa różne zjawiska społeczne. Słowo autorytet wywodzi się z łacińskiego auctoritas i wyraża w szerszym sensie poważanie oparte na posiadanej władzy, w węższym szacunek dla przewagi w uznawanych wartościach (oczywiście $\mathrm{w}$ danym społeczeństwie). Słowo prestiż oznacza czar, urok i pochodzi z języka francuskiego - prestige oraz łacińskiego praestigium. W tym ostatnim języku ma znaczenie jako złudzenie, kuglarstwo, mamidło, oszukaństwo. Jeżeli więc twierdzimy, że ktoś lub coś cieszy się prestiżem, mamy na myśli, iż dany podmiot lub przedmiot wywołuje $\mathrm{w}$ nas odczucie czegoś niezwykłego, skłaniając nas tym samym do mniej lub bardziej irracjonalnych postrzeżeń i myśli na ich temat.

Pierwszym, który podjął badania socjologiczne nad autorytetem i prestiżem był węgierski socjolog L. Leopold. Jego zdaniem prestiż opiera się na uczuciowym stosunku do wartości, które są szanowane w danej grupie społecznej. Przejawia się to w bezkrytycznym stosunku do osób, lub grup cieszących się prestiżem. Autorytet jest w przeciwieństwie do prestiżu następstwem racjonalnego ujmowania wartości (41). 
Do omawianych rozróżnień autorytetu i prestiżu A. Vierkandt zwracał uwagę, że autorytet opiera się na obserwacji i wartościowaniu zarówno osoby cieszącej się nim, jak i jej osiągnięć, które muszą być wymierne oraz kwalifikować się do fachowej oceny (42).

C. Mills w swej "Elicie władzy” zwraca uwagę na fakt, że główne instytucje społeczne są w coraz wyższym stopniu bazą wszelkiego prestiżu (43).

T. Geiger wyróżnił autorytet i prestiż osobisty, wynikający z zespołu przedmiotowych właściwości danego człowieka oraz prestiż urzędowy (pochodny, zewnętrzny) (44).

Szczególnym typem tego ostatniego jest autorytet charyzmatyczny, uważany za następstwo indywidualnego charyzmatu, czyli daru łaski. Z autorytetem charyzmatycznym możemy się spotkać przede wszystkim $\mathrm{w}$ obrębie grup religijnych, ale także $\mathrm{w}$ polityce (co zauważył M. Weber) (45).

Autorytety charyzmatyczne ukazują nie tylko ich zróżnicowanie ze względu na pełnione funkcje, ale $\mathrm{i}$ to, że ich istnienie jest związane $\mathrm{z}$ wiarą ludzi, określonych społeczności, w rozmaicie pojmowane siły nadprzyrodzone, które za pośrednictwem owych autorytetów rodzących się z określonej wiary, przekazują i potwierdzają swoją wolę. Istnienie autorytetu charyzmatycznego stwierdzić można tylko w przypadku gdy ktoś wierzy w określone siły nadprzyrodzone i ich chęć obdarzenia jakiejś istoty ludzkiej szczególną łaską, która sprawi, że ta osoba będzie się wyróżniała, a inni będą jej niezwykłość dostrzegać i będą skłonni za nią podążać. Autorytet w każdej postaci stanowi istotny element życia społecznego. Poddając badaniom strukturę organizacyjną jakiejkolwiek grupy społecznej, możemy przekonać się o występowaniu w niej hierarchii, która jest następstwem zróżnicowanych pozycji poszczególnych jednostek tworzących daną grupę. Nie ma organizacji bez autorytetu, który pełni w niej nader istotną funkcję integracyjną. Przejawia się to w skupianiu ludzi wokół uznawanego przez nich autorytetu. Oprócz integracyjnej, autorytet pełni inną nie mniej ważną funkcję, jako gwarant jej prawdziwości. Ludzie są skłonni wierzyć autorytetom i na nie się powoływać, pomimo iż nieraz mieli możliwość przekonać się o zawodności ich decyzji. Chociaż wiara w autorytety jest wynikiem racjonalnej postawy, rodzi ona pewne niebezpieczeństwa, ponieważ dzięki niej ludzie są skłonni do bezkrytycznego stosunku do wspomnianych autorytetów, zbyt pochopnego uogólniania pomyślnych doświadczeń związanych $\mathrm{z}$ wiarą $\mathrm{w}$ autorytety, przeceniania roli ludzi mających autorytet. Występuje także zjawisko irradiacji autorytetu (autorytet w jednej dziedzinie uważany jest za autorytet $\mathrm{w}$ każdej innej dziedzinie). Autorytet i prestiż są wartościami dość osobliwymi, trudno je stracić, jeżeli się je posiada, ale też niełatwo je zdobyć (46).

Znaczenie autorytetu we wspólnocie można zrozumieć tylko wtedy, gdy spojrzymy na niego jako na dar, czy służbę taką samą jak inne, potrzebne do jej zbudowania. Służba osoby będącej autorytetem we wspólnocie polega na czuwaniu, by żaden człowiek nie utracił najistotniejszego celu wspólnoty, ma też nadawać kierunek wzrostu, tak aby wspólnota nie zagubiła się w drobnych wydarzeniach, w sprawach błahych i przejściowych. We wspólnocie często autorytet jest przedmiotem ataków ze strony niezadowolonych, którzy muszą kogoś za taki stan winić. Niektóre wspólnoty ulegają niebezpieczeństwu utożsamiania osoby obdarzonej autorytetem z prorokiem, kierownikiem duchowym, czy też terapeutą. Staje się on wtedy wszechwładnym pasterzem. Istnieje przy tym niebezpieczeństwo, że taka osoba będzie kierować ludźmi nad którymi ma władzę duchową, dla celów niezgodnych z ideałem wspólnoty. Nie będzie się więc starać, by ludzie ci pozostawali w swym sumieniu wiernymi wspólnym wartościom, lecz zabiegać, by działali dla „dobra ogółu”. Jest to niebezpieczne i stwarza okazję do nadużyć. W ten sam sposób członkowie wspólnoty mogą zastawić pułapkę na osobę będącą autorytetem. Mogą krępować ją rozmaitymi zwierzeniami i tak utrudniać 
właściwe sprawowanie władzy. Mogą nawet wmówić odpowiedzialnemu za wspólnotę, że tylko on potrafi ich zrozumieć, czy im pomóc. Osoba z autorytetem wpada wtedy w szantaż emocjonalny. Dlatego w pewnych sytuacjach lepiej odmówić udzielenia rady, ograniczając się do pomocy w odnalezieniu właściwego miejsca we wspólnocie (47).

W każdym środowisku znajdują się ludzie, którzy lepiej rozumieją otoczenie i osoby oraz rzeczywiście wpływają na dynamizm wspólnoty. Przeżywając te same doświadczenie są bardziej zaangażowani. Spotkanie z tym, który lepiej odczuwa i rozumie swoje życiowe doświadczenie, ale i doświadczenie innych skłania pozostałe osoby w sposób naturalny do pójścia za nim. Dzieje się tak dlatego, że doświadczywszy własnej bezsilności i samotności, ludzkim odruchem jest skłonienie się ku autorytetom i ku wspólnocie z nimi, nawet gdy nie wyróżniają się szczególnymi tytułami, czy uprawnieniami. Autorytetem staje się ten, kto uczciwiej przeżywa swoje doświadczenie. Spotkanie z człowiekiem posiadającym autorytet w sposób naturalny wychowuje naszą wrażliwość i sumienie. pozwala lepiej odkryć strukturę własnej osobowości i poznać cel, ku któremu zdąża wspólnota. Autorytetem najwyższym jest ten, któremu przyznajemy sens całego naszego doświadczenia. Tam gdzie autorytet nie jest wystarczająco czujny i aktywny, lub tam gdzie jest zwalczany, tam droga ludzkiego postępu komplikuje się, staje się zawiła i naznaczona dwuznacznością.

Autorytet jest znakiem wyrażającym jedność, lecz przede wszystkim jest funkcją powołującą i odpowiedzialną za całokształt życia wspólnoty. Wyróżnić można trzy elementy tej funkcji:

- pobudzanie inicjatywy osób do formowania wspólnoty, - zachowania fizjonomii wspólnoty przez precyzowanie i określenie jej granic,

- rozwijanie wspólnoty przez coraz częstsze wcielanie jej w otaczającą rzeczywistość (48).

Przewodnikiem wspólnoty powinna być osoba najbardziej świadoma jej ideałów, które stanowią jej cel oraz najbardziej zdolna do ich przeżywania i dzielenia się nimi. Autorytet zanim stanie się prawem powinien stać się faktem wyjątkowego ducha wspólnotowego. $\mathrm{Z}$ chwilą kiedy autorytet zostanie ustanowiony, wspólnota powinna do niego przylgnąć niezależnie od tego jaka osoba go ucieleśnia. Poszczególny członek wspólnoty nie ma prawa uwolnienia się od poddania autorytetowi, pod pretekstem, iż nie jest on należycie uzdolniony. Autorytet może być usunięty tylko przez regułę, która go powołała. Wspólnota jest urzeczywistnieniem wolności. Właśnie dlatego, że autorytet streszcza i reprezentuje wspólnotę w całkowitej jedności, jego przyjęcie nie jest ograniczeniem ,lecz szczytem wyrazu naszej osobowości. Proces wychowawczy we wspólnocie jest z natury niemożliwy bez autorytetu, ponieważ pozostawia wychowanka samemu sobie. Wspólnota chrześcijańska dowartościowuje i umacnia, wyrażając w najwyższym stopniu regułę wychowawczą, polegają na pójściu za autorytetem. Ta akceptacja może ukazać zupełnie inny rodzaj zaangażowania, który jednostka przeżywa we wspólnocie. Jeżeli wspólnota to moja osoba $\mathrm{W}$ swej większej rzeczywistości, a więc bardziej żywa i wolna, to autorytet trzeba kochać jako najbardziej wyrazistą część samego siebie. Przyjęcie autorytetu w taki sposób rodzi najsilniejsze wspólnoty oparte na prawdziwej, bezinteresownej miłości.

\section{2. Wspólnota jako kategoria religijna}

\section{2. 1. Wspólnota religijna w ujęciu communio (koinonia)}

Zagadnienie miejsca i roli idei wspólnoty zwłaszcza w soborowej (Vaticanum II) wizji Kościoła można rozważać w aspekcie genetycznym i systematycznym. Wizja soborowa nie pojawiła się jak "deus ex machina". Jest ona wynikiem i ukoronowaniem ewolucji z górą stuletniej, której sens można streścić, jako przejście od wizji kościoła ujętego w kategoriach 
socjologiczno - prawnych (societas perfecta) do wizji wspólnoty (communio sanctorum). By zrozumieć sens tej ewolucji należałoby sięgnąć jeszcze do XI wieku, gdzie zaczęła się kształtować nauka o Kościele, określająca bezpośrednią spuściznę eklezjologiczną, odziedziczoną przez nasze czasy. Dążenie do stworzenia z Kościoła jednolitej społeczności, niezależnej od władzy świeckiej, łączy się z nową teorią eklezjologiczną. Biskupi przestaję być pasterzami, stając się administratorami z ramienia papieża. Takie podejście do sprawy zaczęło rodzić szereg kryzysów, a nawet schizm w Kościele. Do aktywów tego okresu można zaliczyć dowartościowanie idei jedności Kościoła, rozbudzenia świadomości, że Kościół zdecydowanie afirmuje autonomie od instytucji świeckich. Do pasywów należy zacieśnienie eklezjologii do sprawy władzy w Kościele, uczynienie podstawowym kryterium uległości wobec papieża. Zagroziło to utratą wizji Kościoła jako wspólnoty.

Za początek ruchu odnowy eklezjologicznej, którego ukoronowaniem był Drugi Sobór Watykański, można uznać wysiłki tzw. teologicznej szkoły tybindzkiej z połowy XIX wieku, zwłaszcza wkład J. Möhlera. Pod wpływem niemieckiego romantyzmu, z jego ideą życia i wspólnoty życiowej, dochodzi do nowego spojrzenia na Kościół jako żywy organizm. Idea mistycznego ciała stanowiła niewątpliwie krok naprzód w dążeniu do wspólnotowego ujęcia istoty Kościoła. Potrzebne było też uwolnienie od powiązań z tradycyjną koncepcją Kościoła, z jej naturalno - prawnym punktem wyjścia. Soborowe ujęcie wspólnoty uwydatnia jej aspekt wertykalny i horyzontalny. Wizja Kościoła zawarta w soborowej Konstytucji Dogmatycznej o Kościele (Lumen Gentium) przedstawiana jest jako pneumatyczna eklezjologia wspólnoty oraz eklezjologia służby. Możliwość ujęcia Kościoła jako wspólnoty warunkuje dokonane przez soborową Konstytucje przejście $\mathrm{z}$ eklezjologii jurystycznej i apologetycznej do eklezjologii mającej swe centrum w misterium. W skład centralnego pojęcia wspólnoty (koinonia) wchodzą dwa czynniki - przedmiot uczestnictwa (to czym się uczestniczy) i osoba, z którą się uczestniczy. Mając na uwadze osobę, z którą nawiązuje się łączność poprzez uczestnictwo, lepiej używać słowa komunia (łączność) (49).

A. L. Szafrański zwraca uwagę, że koinonia jest rzeczywistością religijną, powstałą na skutek nawrócenia (konwersji) i przyjęcia chrztu. Rzeczywistość ta do końca nie daje się według niego wytłumaczyć w kategoriach pojęć filozoficznych czy socjologicznych. Kościół jest wspólnotą jednoczącą hierarchię i wiernych w pojęciu Ludu Bożego, jest wspólnotą żywą i nie mającą na zawsze ustalonego miejsca w czasie i przestrzeni, bowiem pielgrzymuje do wieczności. Koinonia Kościoła znajduje swoje teologiczne uzasadnienie w Trójcy Świętej. Istnieje podwójny porządek pośrednictwa: chrystologiczny i pneumatologiczny (eklezjalny). Pośrednictwo osobowe, wyrażające się w relacji "ja -ty" oraz pośrednictwo wspólnototwórcze, jawiące się w świadomości bycia Kościołem "my”, łącznie z wszystkimi ludźmi, szczególnie wierzącymi i ochrzczonymi. Nie można wyczerpać prawdy o Kościele w pojęciu wspólnoty bez podkreślenia jej służebnego charakteru (diakonii). Istnieje pięć możliwości zdefiniowania tego ostatniego terminu:

- zaprzeczenie buntu ludzkości przeciwko Bogu (non serviam),

- czynna odpowiedź na Boże wezwanie, osobowe oddanie się bliźniemu by zaspokoić jego materialne i duchowe potrzeby. Jest to istotą chrześcijańskiej gminy (parafii) jak też każdego chrześcijanina,

- postawa służebna Kościoła i wspólnot chrześcijańskich wobec potrzeb człowieka, urzeczywistnienie w zakresie egzystencji nadprzyrodzonej, poprzez apostolat i różne formy duszpasterstwa, w zakresie egzystencji przyrodzonej - przez dobroczynność. Należy też do trzech podstawowych funkcji kościoła (liturgia, martyria, diakonia),

- świadome podjęcie służebnego i zbawczego działania Chrystusa przez wspólnotę chrześcijańską. Diakonia Kościoła realizowana w nim samym powinna charakteryzować 
się dialogiem i partnerstwem oraz społeczno - charytatywnym zaangażowaniem w sensie budowania otwartej braterskiej wspólnoty,

- ujęcie prawosławne diakonię rozumie jako przepowiadanie Bożego miłosierdzia, służba wobec bliźnich, służba stworzeniu (ekologia), służba całej ludzkości, jako przedsmak i znak wieczności, także jest postrzegana jako czynność liturgiczna.

Charyzmatyczna struktura Kościoła, którą określamy mianem wspólnotowo diakonalnej, nie znosi, a nie zaprzecza instytucjonalnej. Władza zostaje ukazana jako służba (50).

Communio oznacza wspólnotę jako skutek, ale nie oznacza jej przede wszystkim. Wspólnota może oznaczać to co zawiera się w pojęciu communio, jeżeli założymy, iż wskazuje ona na taki sposób wspólnego bytowania, który służy osobowemu spełnieniu każdej z osób ją stanowiących. Takie rozumienie pojęcia wspólnoty odpowiada dokładnie treści wypowiedzi soborowych na temat człowieka, uwzględnia bowiem zarówno to, że człowiek jest jedynym na ziemi stworzeniem, którego Stwórca chciał dla niego samego, jak też i to, że człowiek nie może się w pełni odnaleźć inaczej, jak tylko przez bezinteresowny dar z siebie samego.

Parafia jest pewną wspólnotą wiernych ustanowioną na stałe w Kościele partykularnym i powierzoną przez biskupa proboszczowi jako jej pasterzowi. Bez związku z biskupem i pozostałymi kościołami partykularnymi parafia nie byłaby autentyczna i pełnowartościowa $\mathrm{w}$ sensie kościelnym. Łączność $\mathrm{z}$ pasterzem pełniącym funkcję jednoczącą i kierowniczą $\mathrm{W}$ kościele partykularnym pozwala na pełną realizację swych zadań oraz na utrzymanie więzi z Kościołem powszechnym. Właśnie tego typu struktury kościelne - nie sumy poszczególnych jednostek ale wspólnoty, często odrębne co do charakteru, ale zazębiające się, współistniejące, często przenikające się czy pozostające w łączności in communione zapewnia małym społecznościom uprawnienie do otrzymania pomocy wzajemnej i pasterskiej. Wśród rozmaitych koncepcji teologicznych parafii, zdaje się dojrzewać wizja tzw. małego Kościoła. Każda parafia stanowi jedną z podstawowych wspólnot Kościoła partykularnego i pełni pod przewodnictwem lokalnego pasterza, w określonym dla niej zakresie podstawowe zadania. Wspólnota parafialna jest elementem łączącym inne istniejące w niej społeczności o rozmaitym charakterze i działaniu począwszy od rodziny. Dzięki tej małej wspólnocie wspólnot nie tylko jednostki mogą mieć ze sobą kontakt, ale też ułatwia im się współdziałanie na forum publicznym (51).

Nadzwyczajny Synod Biskupów w 1985 r. nadał wspólnocie szczególne znaczenie, czyniąc ją jednym z najważniejszych określeń tajemnicy kościoła. Synod określa pojęcie wspólnoty jako tajemnicę osobistego zjednoczenia człowieka z Trójcą Świętą i innymi ludźmi, mającą swój początek w wierze. Jest ona nakierowana na eschatyczne wypełnienie w Kościele niebieskim, jednakże zasługującą na swoje początkowe i przejściowe wypełnienie w Kościele ziemskim. Autorzy dokumentu opublikowanego w 1992 r. przez Kongregację ds. Doktryny Wiary odwołują się wyraźnie do zasady jedności, która ma wynikać już z samego pojęcia wspólnoty. Dokument stara się poruszać na płaszczyźnie pryncypialnej, jakby nie uwzględniając wymiaru praktycznego. Autorzy dokumentu podkreślają, że pojęcie wspólnoty odniesione analogicznie może dać podstawę do pojmowania Kościoła powszechnego, jako wspólnoty kościołów lokalnych. Niekiedy jednak idea wspólnoty w kościele lokalnym jest używana $\mathrm{w}$ ten sposób, że zostaje przy tym osłabiony obraz jedności kościoła $\mathrm{w}$ jego widzialnej, instytucjonalnej postaci, aż do twierdzenia, że cały kościół lokalny jest sam z siebie zupełnym podmiotem, zaś kościół powszechny to jedynie wynik wzajemnego uznania kościołów lokalnych. Jedność kościołów lokalnych zasadza się na Eucharystii. Choć jest ona sprawowana we wspólnocie kościoła partykularnego, to jednak w tym momencie staje się 
odbiciem i aktualizacją kościoła powszechnego. Jedność i powszechność kościoła nie tylko nie utrudnia i zagradza drogi do jedności kościołów lokalnych, lecz nadaje jej charakter wspólnoty. Zalążkiem jedności Kościoła jest Lud Boży (wierni). Teologiczna kategoria Ludu Bożego stała się znamieniem i wiodącą ideą soborowej eklezjologii (52).

Synod Biskupów z 1985 r. jako kontynuacja drogi rozpoczętej przez Vaticanum II przezwycięża rozziew między naturalnym, a nadprzyrodzonym statusem Kościoła. Opisuje go mianowicie jako Lud Boży w drodze, jako wspólnotę na wygnaniu podążającą ku pełnej chwały przyszłości. Tak rozumiana misja Kościoła ma na celu nie tylko wyzwolenie spod jarzma grzechu i śmierci, lecz zakłada obowiązek poważnego zakrzątnięcia się wokół ziemskiej realizacji dóbr tego wiecznego Królestwa, troską o doczesne zręby jego prawdy, sprawiedliwości i pokoju tu i teraz. Pojęcie communio (koinonia) oparte na Piśmie św., w Kościele starożytnym i w Kościołach wschodnich aż po dziś dzień cieszy się wielką czcią. Stąd Vaticanum II uczynił wiele, aby Kościół był wyraźniej rozumiany jako komunia i bardziej konkretnie jako komunia urzeczywistniany (53).

Godny uwagi jest też dorobek teologów soborowych w zakresie wizji Kościoła jako wspólnoty wspólnot. F. Klosterman doszedł do wniosku, że wspólnota jest centralnym miejscem i elementem urzeczywistniania się Kościoła do tego stopnia, że z zasady ukazuje się on światu przede wszystkim jako wspólnota. Obecność Kościoła w świecie w sposób zasadniczy uzależniona jest od wcielenia się w konkretną wspólnotę. Autor odwołuje się do specyficznego chrześcijańskiego sensu pojęcia wspólnota, które ma swoje źródła w nowotestamentalnym terminie ecclesia. N. Greinacher twierdził, że Kościół wspólnotowy cechuje postawa misyjna, otwartość na świat i eschata. W swym kształcie strukturalnym będzie to Kościół wspólnot terytorialnych i funkcjonalnych (54).

Odkrycie wspólnotowego wymiaru Kościoła jest możliwe przez tradycję (Pismo św. i przekaz ustny). Zachwiana jest przy tym równowaga (98 \% Pismo św. i $2 \%$ przekaz ustny). W Kościele rozumianym jako wspólnota należy często sięgać do najstarszych nawet dokumentów i przekazów ustnych, które nam ten Kościół wspólnotowy ukazują. Według słownika teologicznego wspólnota $w$ omawianych znaczeniach jest związkiem między osobami na trwałych więzach wewnętrznych. Kościół jako wspólnota może być rozumiany w kategoriach tradycji chrześcijańskiej pierwszych wieków, jako obraz ukazywany w pismach oficjalnych Kościoła i teologów oraz jako ich realizacja. Wspólnota, którą jest Kościół realizuje się na różnych płaszczyznach: w parafiach, diecezjach, Kościele powszechnym. Małe wspólnoty, także działające przy parafii organizacje i ruchy, pozwalają na pewne doświadczenie Kościoła jako wspólnoty. Doświadczenie wspólnotowego charakteru Kościoła w parafii jest uzależnione od ilości więzi i ich rodzaju, między duchownymi a wiernymi świeckimi. Łącząc wszystkich członków parafii we wspólnoty małych grup otwiera się ich przez Eucharystię na sprawy i rzeczywistość Kościoła powszechnego (55).

Duży wpływ na zainteresowanie zagadnieniem wspólnoty w znaczeniu koinonia miał powrót do źródeł, zwłaszcza do Pisma św. Biblijna koinonia nie podważa w niczym wspólnoty $\mathrm{w}$ znaczeniu socjologicznym, przeciwnie, pogłębia ją i rozszerza o wymiar nadprzyrodzony. Wspólnota naturalna (socjologiczna), stanowi fundament wspólnoty religijnej (56).

Wspólnota religijna jest, ściśle rzecz ujmując, jednością organiczną, analogiczną do jedności żywego sprawnego ciała. Oznacza się ona w istocie współistnieniem wielorakich powołań, stanów tajemnic i zadań, które choć są różne, w stosunku do siebie są komplementarne. Ta różnorodność i komplementarność sprawia, że każdy świecki pozostaje w relacji do całości i wnosi swój własny wkład. Wierni powinni przyjmować dar wspólnoty z poczuciem odpowiedzialności. Konkretnym wyrazem tej odpowiedzialności jest ich udział w 
życiu i posłannictwie Kościoła, któremu służą poprzez różne komplementarne posługi i charyzmaty. Wierny nie może nigdy zamknąć się w sobie, izolować duchowo od wspólnoty, lecz powinien żyć w nieustannym kontakcie z innymi przepełniony poczuciem braterskiej więzi, przepełniony radością płynącą z jednakowej godności oraz świadomy wspólnej odpowiedzialności. Tak więc różnorodność służy budowaniu wspólnoty (57).

Powszechność Kościoła oznacza z jednej strony podstawową jedność, a z drugiej strony wielość i zróżnicowanie, które nie przeszkadza jedności, ale nadaje jej charakter komunii. Wielość ta odnosi się zarówno do różnorodności posług, charyzmatów, form życia i apostolatu wewnątrz Kościoła partykularnego, jak i do różnorodności tradycji liturgicznych i kulturowych między różnymi Kościołami partykularnymi. Promocja jedności, która nie przeszkadza różnorodności, jak również uznawanie i promocja zróżnicowania, jak również uznawanie i promocja zróżnicowania, która nie przeszkadza jedności, ale ją ubogaca, jest pierwszorzędnym zadaniem papieża wobec całego Kościoła oraz każdego biskupa w jego Kościele partykularnym. Budowanie i strzeżenie tej jedności, która dzięki różnorodności uzyskuje charakter komunii, jest także zadaniem wszystkich wiernych, ponieważ oni są powołani do tego, by ją kształtować i zachowywać każdego dnia, przez miłość jako więź doskonałą. Dla pełniejszego ujęcia tego aspektu komunii eklezjalnej, jakim jest jedność w różnorodności, należy zauważyć, że istnieją instytucje i wspólnoty ustanowione przez Kościół dla szczególnych zadań pastoralnych, chociaż ich członkowie są także członkami kościołów partykularnych, w których żyją i pracują. W kontekście Kościoła pojętego jako komunia zauważyć trzeba, że istnienie licznych instytutów życia konsekrowanego i apostolskiego, chociaż należą one do struktury hierarchicznej Kościoła, są także wyrazem jego życia, zaś ze względu na ich (z reguły) ponaddiecezjalny charakter, wszystkie te rzeczywistości służą komunii między kościołami partykularnymi (58).

Pojęcie wspólnoty communio pozwala adekwatnie wyrazić głęboką treść tajemnicy Kościoła. Pojęcie to ma wymiar wertykalny (komunia z Bogiem) i horyzontalny (komunia z ludźmi). Występuje przy takim rozróżnieniu także wymiar niewidzialny (wspólnota z Trójcą św.) oraz widzialny (komunia w nauce Apostołów, w sakramentach i porządku hierarchicznym). Komunia ta nie jest tylko natury moralnej, ale ontycznej i nadprzyrodzonej implikują duchową solidarność między członkami Kościoła (59).

We współczesnej myśli pastoralnej często zwraca się uwagę, że jedną z najpilniejszych spraw jest nieustanne budowanie rzeczywistej komunii Kościoła. Kościół funkcjonuje albo jako wspólnota, albo wyrodnieje i zamiera. Żyjąc w sytuacji głębokich gett, nawet jeśli powstają aktywne środowiska i wspólnoty wiary potrafią one odciąć się od reszty, zamknąć W sobie i zatracić posłannictwo apostolskie. Wielu obojętnych i gorliwych religijnie ignoruje Kościół jako wspólnotę, żyjąc praktycznie poza nim. Największa kumulacja tych problemów następuje $\mathrm{w}$ parafii. W niej $\mathrm{w}$ obecnych czasach następuje coraz większa marginalizacja $\mathrm{i}$ oddalanie się ochrzczonych od centrum parafii i grup odnowy. Istnieje niebezpieczeństwo, że w wyniku tego oddalenia zostanie zagubiony cały dynamizm chrześcijaństwa. Kościół stanie się środowiskiem wzajemnej adoracji, a nie nośnikiem uniwersalnej misji i służby. Brak jest świadomości struktur pośrednich, podstawowych dla dojrzałego życia Kościoła (wspólnot sąsiedzko - rodzinnych). Głębokie potrzeby ludzkie: podmiotowość, uczestnictwa, nie są zaspokajane zwłaszcza w wielkich skupiskach kościelnych. Jeżeli zabraknie tej świadomości, coraz więcej ludzi będzie uciekać do sekt (60).

Kościół jest zjawiskiem, które powstaje jako wspólnota ludzka i religijna wokół Ewangelii, która jest głoszona. Elementy istotne takiej wspólnoty to: postawa wolności poszczególnych osób, rzeczowość relacji między osobowych, świadomość wspólnoty wewnętrznej. Wspólnota Kościoła jest zjawiskiem, które nie bazuje na żadnych 
dotychczasowych wspólnotach. Jest zjawiskiem wyjątkowym i jedynym w swoim rodzaju. Posiada pewne elementy, które określają tą wspólnotę, którą Kościół realizuje. Pierwszym elementem jest rzeczywistość międzyosobowa zjawiska. Przekazywanie Ewangelii nabiera znaczenia jako spotkanie międzyosobowe absolutnie determinujące. $Z$ tego spotkania rodzi się wspólnota ludzi zaangażowanych $\mathrm{w}$ to samo przeżycie i $\mathrm{w}$ tę samą historię. Wspólnota jest więc nie tylko celem, lecz zasadza się na głębokiej relacji międzyosobowej, którą buduje głoszona i przyjęta Dobra Nowina. Drugim elementem charakterystycznym jest aspekt przedmiotowy przekazu. Nie ma prawdziwej, autentycznej wspólnoty miedzy ludźmi, jeśli doświadczenia wewnętrzne nie są ubrane $w$ słowa i fakty, czyli znaki zewnętrzne historycznie sprawdzalne, poprzez wydarzenia świadomości stają się wydarzeniami historii i tworzą ludzka historię jako historie ludzkości, wspólnot ludzkich, a nie tylko pojedynczych osób. Przekazuje się więc własne doświadczenie Boga, w którym jest On tym samym, którego widzieli Apostołowie. Trzecim elementem zjawiska jest wspólnota. Jest ona spontanicznym owocem bardziej, niż określonym celem przekazu. Wiele razy Nowy Testament podkreśla ten aspekt zbawienia, jest on przezwyciężeniem podziałów, zburzeniem murów, uniwersalnym braterstwem. Kościół nie jest tylko narzędziem do osiągnięcia zbawienia, które jest tylko wysoko. Jest on tu, poprzez swoje istnienie, wspólnotą miłości, pierwszą realizacją zbawienia, Wspólnota ta jest oparta na przekazywaniu wzajemnym doświadczenia Boga. To, co prowadzi do tej wspólnoty, to wspólnota z wierzącymi, którzy zebrali się w imię Boga. Nie ma nic w Kościele, co byłoby czysto instrumentalne. Element międzyosobowy gwarantuje jego pochodzenie od dobrowolnego przyjęcia wiary, jego istnienie oparte na dobrowolności jego członków. Element przedmiotowości warunkuje konieczność autorytetu, którym jest przede wszystkim słowo Boże, czyli głoszenie jego w pierwotnej formie. Wspólnota ma być pogłębieniem rozumienia liturgii, a nie jej odrzuceniem (61).

W aspekcie trynitarnym wspólnota ma sama w sobie wartość. Każda wspólnota lokalna zgromadzona przez słowo Boże i sprawująca sakramenty (zwłaszcza Eucharystię) urzeczywistnienia się jako Kościół w modlitwie, współpracy i dziele ewangelizacji wszystkich narodów. W ten sposób wspólnota lokalna, otwarta na współpracę w dziele zbawienia ludzi staje się w pełni katolicką (ka-thole-gé) gr. po całej ziemi.

Wyrazem komunii kościołów w jednej misji głoszenia Ewangelii całemu światu jest ich wzajemna solidarność. Dziś Kościół musi uczynić wielki krok naprzód na drodze ewangelizacji, wkroczyć w nowy etap swojego misyjnego dynamizmu. W świecie, który dzięki pokonaniu odległości staje się coraz mniejszy, wspólnoty kościelne powinny utrzymywać ze sobą łączność, wzajemnie wspierać swe siły, dzielić się środkami, razem angażować się w jedną wspólną misję przepowiadania Ewangelii i życia według jej wskazań. Nie ma prawdziwej komunii kościołów bez kształtowania ich życia w wymiarze daru, dlatego łaska odnowy może wzrastać we wspólnotach kościelnych tylko wówczas, jeśli każda z nich rozszerza granice swojej miłości, aż po krańce ziemi i troszczy się o tych, którzy są z dala, w podobny sposób, jak o tych, którzy ją stanowią. Komunia i misja są ze sobą mocno związane. One przenikają się wzajemnie, implikując tak dalece, że komunia jest równocześnie źródłem i owocem misji. Komunia jest misyjna, zaś misja służy komunii (62).

Kościół pojmowany jako wspólnota jest tematem centralnym wszystkich dokumentów Vaticanum II. Specyfiką tej wspólnoty jest to, że jest ona wspólnotą w trakcie gromadzenia się, w budowie (en construction) stająca pomiędzy wspólnotą podstawową ludzi stworzonych na obraz boży, a wspólnotą eschatologiczną (pełną). Tę naturę przejściową (pośrednią) Kościoła określa termin sakrament. Kościół pielgrzymujący jest sakramentem jedności, znakiem i narzędziem odbudowy wspólnoty pierwotnej, we wspólnocie eschatologicznej. 
Kościół jako wspólnota jest ujmowany w dokumentach soborowych dynamicznie. Wspólnota i jej budowanie jest celem i zadanie Kościoła. Wszystko w nim musi być skierowane ku budowaniu wspólnoty. Nie ma takiego obrazu Kościoła, czy takiego pojęcia lub idei, do jakich sięgnąłby Sobór, dla wyrażenia tajemnicy Kościoła, które nie wskazywałyby na wspólnotę jako na oznaczoną rzeczywistość i najgłębszą treść. Wspólnota stała się jedynym określeniem Kościoła, które nie jest tylko obrazem, ale wyraża wprost samą rzeczywistość oznaczaną przez te obrazy. Dlatego wszystkie one domagają się wyjaśnienia poprzez ideę wspólnoty. Wśród soborowych określeń Kościoła jest tylko jedno, które dodaje do pojęcia wspólnoty, jaką jest Kościół coś istotnego, czego nie można z niego wyprowadzić. Jest to określenie Kościoła jako sakramentu. Określa ono specyfikę Kościoła (wspólnoty) w stosunku do wspólnoty eschatologicznej, z którą Kościół się nie pokrywa. Określenie to stanowi "differentiam specificam” w określeniu Kościoła jako wspólnoty, podczas gdy samo pojęcie wspólnoty można określić jako "genus proximum", obejmujące zarówno wspólnotę ostateczną, jak i realizowaną w czasie. Nie wystarczy mówić: "Kościół jest wspólnotą", trzeba określić dokładniej: Kościół jest sakramentem wspólnoty (63).

\section{2. 2. Wspólnota religijna jako kategoria socjologiczna}

Religia jest wynikającym z dualistycznego rozróżnienia na rzeczywistość empiryczną i transcendentną, systemem wierzeń, który choć sam nie poddaje się racjonalnej weryfikacji, wyjaśnia w sposób możliwy do przyjęcia to, co inny sposób wytłumaczyć się nie da. Odpowiadające tym wierzeniom symbole i formy zachowań kultowych, zbiór wartości i norm moralnych odwołujących się do autorytetu Boga i Kościoła, a określający wzór osobowy człowieka religijnego oraz jednocząca wyznawców we wspólnotę organizacja kościelna (64).

Socjologia religii stara się zbadać charakter zespołowy zachowania duchowego, podkreśla poczucie solidarności, które jest jednym z punktów odniesienia postępowania moralnego, odkrywa pewne zespoły danych, które charakteryzują postawy danego środowiska danej grupy i poszczególnych jednostek. Wspólnota religijna jest rzeczywistością mistyczną i trzeba wysiłku, by ją zbudować (65).

Tylko dostatecznie zwarta terytorialnie parafia, tworząca żywą grupę społeczną umożliwia szybką identyfikację jednostki z grupą. Uczestnictwo $\mathrm{w}$ grupie jest wówczas ułatwione przez stosunki interpersonalne. Przynależność religijna ma charakter odniesienia bezpośredniego i lokalnego. Gdy parafia jest rozległa i anonimowa, uczestnictwo indywidualne parafian staje się praktycznie niemożliwe dla bardzo dużej ich części (66).

W najwcześniejszych dokumentach Kościoła realizacja wspólnoty w radykalnym tego słowa znaczeniu, była widziana jako obietnica i cel Ewangelii. Do czego zatem nawołuje Kościół mówiąc o jedności między nauką, a religią? Obie te dziedziny powinny osiągnąć wzajemne zrozumienie. Sedno zagadnienia stanowi fakt, że Kościół i wspólnota naukowa nieustannie oddziałują między sobą, wśród stojących przed nimi możliwości nie ma izolacji. Wierzący będą niechybnie przyswajać sobie panujące poglądy na świat, a te są dziś głęboko kształtowane przez naukę. Jedynym pytaniem pozostaje, czy będzie się dokonywało z wyczuciem głębi i niuansów czy powierzchownie, w sposób krytyczny, czy zupełnie bezrefleksyjny. Zarówno Kościół jak i wspólnota naukowa stają w obliczu tych alternatyw, przed którymi nie ma ucieczki. Będziemy dokonywać naszych wyborów znacznie lepiej, jeśli będziemy żyć we wzajemnej współpracy do której jesteśmy wezwani, którą mamy realizować coraz pełniej. Jedynie dynamiczne relacje między teologią i nauką mogą odkryć przed nami te granice, które utrzymują integralność każdej z tych dyscyplin (67). 
J. McMurray twierdzi że dziedzina religii, jest dziedziną stosunków międzyludzkich, jest ona świadomą realizacją wzajemnych współzależności. Realizacja ta jest socjologicznym następstwem podstawowego doświadczenia religijnego- sacrum, jakkolwiek ważna, to jednak wtórna. Nadaje szczególne znaczenie czynnościom symbolicznym. Sugestywna jest jego interpretacja, że nie tylko są one celebrowaniem świadomości wspólnoty, lecz płyną z niepewności wszelkiej wspólnoty. Ceremoniał religijny nie jest dla niego samym tylko wyrazem świadomości wspólnoty, lecz również środkiem jej utrzymania. Doskonałym środkiem wytwarzającym zainteresowanie i pobudzającym członków grupy religijnej do współdziałania jest zawsze nakładanie obowiązków i odpowiedzialności, wyróżnień i przywilejów. Życie grupy, której spoistość opiera się na przesłankach religijnych zawsze będzie koncentrować się na wspólnocie kultu. Wspólnota ta może integrować się na różne charakterystyczne sposoby. Nawet milczenie, zdające się z pozoru wykluczać wspólnotę staje się potężnym środkiem integracji (68).

Z natury społecznej człowieka wynika, że istnieje wzajemna zależność między postępem osoby ludzkiej a rozwojem społeczeństwa. Osoba ludzka jest i powinna być zasadą, podmiotem wszystkich prac, urządzeń politycznych oraz społecznych. Spośród powiązań społecznych koniecznych człowiekowi do jego wyrobienia, jedne (rodzina, wspólnota polityczna) odpowiadają bardziej bezpośrednio jego najgłębszej naturze ,inne pochodzą z jego wolnej woli (69).

Spojrzenie na Kościół jako na wspólnotę braterską prowadzi do ujęcia go w konkretnej wspólnocie lokalnej. Wspólnota braterska zawiązuje się w bezpośrednich międzyosobowych kontaktach a nie w ramach Kościoła pojętego jako anonimowa abstrakcyjna wielkość. Vaticanum II widząc Kościół partykularny, zasadniczo skupiony wokół biskupa (diecezja), uznaje za pełne i prawdziwe wcielenie Kościoła powszechnego wspólnoty mniejsze, skupione wokół wydelegowanych przez biskupa kapłanów. Wśród tych wspólnot najbardziej typową jest parafia. Nie jest ona jedyną możliwością realizacji Kościoła (poza diecezją).

Wśród wspólnot mniejszych niż parafia, mających szczególną wymowę znaku Kościoła powszechnego, należy wymienić przede wszystkim wspólnoty zakonne i organizacje oraz ruchy religijne o dużym zasięgu, Dokumenty soborowe wskazują na rodzinę jako najmniejszą i podstawową wspólnotę, w której ma się urzeczywistniać Kościół i która ma być małym Kościołem (eklezjolą) (70).

Współcześni socjologowie religii zwracają uwagę na zanikanie w parafiach miejskich poczucia przynależności do instytucji religijnych. O niektórych aspektach tych zmian pisze J. Fichter: „Jest bardzo możliwe, że parafie małych wiosek zbliżają się ku ideałowi grupy wspólnotowej. W parafii miejskiej znaczna większość wiernych zdaje się korzystać z kościoła lokalnego, jako pewnego rodzaju „station - service”, dla zaspokojenia swych potrzeb religijnych. Ich społeczna więź wspólnotowa z księżmi i innymi parafianami podobna jest do więzi, którą może mieć właściciel samochodu z kierownikiem stacji benzynowej” (71).

W parafiach miejskich badacze często zwracają uwagę na różne formy interakcji w płaszczyźnie religijnej, które stanowią podstawę do tworzenia się więzi społecznej. Udział w praktykach religijnych nie zawsze jest nacechowany wspólnotowo. E. Pin wyróżnia trzy sposoby uczestnictwa w praktykach religijnych:

- wspólnotowo - ekspresywny, przyczyniający się do wzmocnienia parafii jako wspólnoty lokalnej, przy wykorzystaniu różnych środków ekspresji,

- indywidualno - instrumentalny, prowadzący nie do ugruntowania istniejącej już wspólnoty, ani tworzenia nowej, lecz do zaspokojenia indywidualnych potrzeb religijnych,

- wspólnotowo - symboliczny, służący tworzeniu się nowej wspólnoty o charakterze ściśle religijnym, tzn. zgromadzenia eucharystycznego. W tym ostatnim sposobie istotne 
znaczenie ma poziom uświadomienia uczestniczących, zaangażowanie w rolę uczestnika i przedłużenie swego uczestnictwa w życiu na co dzień, poprzez postawę świadka (72).

Uczestnictwo jako sposób bycia w Kościele jest też sposobem realizacji posłannictwa chrześcijańskiego w świecie. Jest to bycie z człowiekiem, udział w jego losie, współbycie, współpraca, wspólnota. Odpowiada to jak najbardziej powołaniu chrześcijańskiemu, którego konsekwencją w planie moralnym jest poczucie więzi braterskiej ze wszystkimi ludźmi (73).

Przejawem udziału świeckich w misji Kościoła jest praca w tzw. grupach nieformalnych (spontanicznych). Upowszechnia się przekonanie, że istnienie małych grup religijnych nie jest jakimś luksusem pastoralnym lecz praca w nich jest integralną częścią normalnej działalności Kościoła. Akcentowanie wspólnotowego życia religijnego w małych grupach nieformalnych, może mieć ważne reperkusje dla miejsca i roli katolików świeckich w Kościele. W grupach nieformalnych, których profile są różnorodne, działalność skupia się na studiowaniu Pisma św., pogłębianiu wiary, aktywnej miłości bliźniego, wspólne poszukiwanie sensu własnej egzystencji. Wiara staje się czymś, co przeżywa się wspólnotowo i osobowo zarazem, co skłania do podejmowania cennych inicjatyw ewangelizacyjnych.

Urzeczywistnienie posłannictwa Kościoła zależy od zjednoczenia w miłości wszystkich chrześcijan, które jest odblaskiem komunii. Posłannictwo ludzi świeckich jest nacechowane swoistą bezpośredniością stosunków ze światem (74).

Małe wspólnoty powstające w parafiach mają na celu:

- pogłębianie modlitwy, wiedzy religijnej, formowanie postawy apostolskiej przez studium Pisma św., nauk teologicznych i społecznych,

- podejmowanie konkretnych zadań apostolskich w parafii, takich jak: porządkowanie, zadania wychowawcze, charytatywne, katechetyczne, dekoracyjne.

Jeżeli parafia jest wspólnotą wspólnot, to stanowi nadprzyrodzone oraz społeczne podłoże tych wspólnot. Małe wspólnoty mogą powstawać całkiem swobodnie, zależnie od zadań, jakie należy w danej parafii wykonywać. Warunkiem powstania wspólnoty jest jasno określony cel i środki do jego realizacji - nieoddzielenie się od głównego nurtu życia parafii lecz wspomaganie go według możliwości (75).

Proces socjalizacji, polegający na wprowadzeniu jednostki do udziału w życiu i kulturze danego społeczeństwa, dokonuje się w małych grupach. Grupy te zarówno pierwotne (rodzina, sąsiedztwo, grupy rówieśnicze), jak i wtórne, tworzone dla określonych celów, przekazują swoim członkom kulturę wielkich grup społecznych, w skład których wchodzą. Co więcej przez uczestnictwo w małych grupach realizuje się uczestnictwo jednostki w życiu wielkich grup. Kościół w swoim wymiarze społecznym jest wielką grupą społeczną i odnoszą się do niego prawidłowości jakie obowiązują w wielkich grupach. Kościół urzeczywistnia się przez małe grupy. Element wspólnotowy Kościoła, przesłonięty dawniej elementem instytucjonalnym wybija się dziś w myśli teologicznej i w świadomości coraz większej liczby wiernych, na pierwszy plan. Soborowe i posoborowe dokumenty podkreślają ogromne znaczenie wspólnot religijnych. Wielu autorów, zarówno teologów jak i socjologów, twierdzi, że małe grupy są przyszłością Kościoła. Jeśli Kościół przez swoich wiernych ma być obecny w strukturach świata, to muszą oni zasilać się nie tylko w grupach kościelnych typu parafia, lecz także $w$ innych małych grupach umożliwiających kontakt bezpośredni, wymianę myśli i doświadczeń. Jeśli Kościół ma ogarnąć pokolenia, które przyjdą, to już dziś ludzie młodzi muszą w nim widzieć swoje miejsce i uczestnicząc $\mathrm{w}$ małych grupach wdrażać się do podejmowania ról, których tu i teraz oczekuje się od nich. 
Tylko w ten sposób wykształcić się mogą dojrzałe osobowości twórcze członków Kościoła. Zadanie wspólnot w Kościele polega przede wszystkim na:

- włączaniu jednostek w życie kościoła, jako podmiotów a nie przedmiotów czyichś oddziaływań, dowartościowując jednostki, wydobywając je z anonimowej masy, wyzwalając inicjatywę i odpowiedzialność,

- umożliwiają przedyskutowanie różnych problemów, a co za tym idzie lepsze zrozumienie wielu spraw i pogłębienie świadomości religijnej,

- ułatwiają przejście od zasad ogólnych do osobistych decyzji,

- pomagają w rozwoju wiary i pobudzają do życia płynącego z wiary, inspirują do apostolstwa, pozwalają na zoperacjonalizowanie ogólnych celów przez wytyczenie konkretnych zadań (76).

Wprawdzie wszystkie teksty Nowego testamentu mówiące o Kościele wskazują nań, jako wspólnotę, ale niektóre posiadają znaczenie szczególne, niemal techniczne. Wraz z określeniem (meros - część, udział; metoche - uczestnictwo, zespolenie) wskazują na związek ludzi z Bogiem i pomiędzy nimi w Kościele. Pojęcie wspólnoty w odniesieniu do Kościoła uwzględnia sens bierny i czynny, statyczny (wspólnota jako coś trwałego) i dynamiczny (wspólnota budowana i realizowana wspólnym wysiłkiem), wymiar wertykalny i horyzontalny, znaczenie osobowe (wspólnota osób) i rzeczowe (wspólnota dóbr). Kościół jako wspólnota nie niszczy więzów naturalnych między ludźmi, lecz też do nich się nie sprowadza. Wspólnota Kościoła jest rzeczywistością i zadaniem. Jawi się ona jako „dar z góry", a jednocześnie jako owoc oddolnej współpracy z tym darem. W tym ostatnim przypadku wymaga ona dobrej woli od tych, którzy ją tworzą, wysiłku, krytycyzmu i zapału do jej doskonalenia. Ecclesia semper reformanda. Reformowanie instytucji, przepisów, rytów, ceremonii, tradycji i zwyczajów ma zawsze na celu wspólnotę. Zachodzi ścisłe powiązanie wspólnoty i osób. Osoba może w pełni się rozwijać tylko we wspólnocie, prawdziwa zaś wspólnota może istnieć tylko pośród osób (77).

Kościół jest tajemnicą wspólnoty w tym sensie, że jest sakramentem, który ją wprowadza i coraz bardziej jej doświadcza. Kościół nie jest użytkownikiem wspólnoty lecz jej źródłem (78).

Dla badacza zjawisk religijnych analiza przyczyn, praw socjologicznych i motywacji psychologicznych, tkwiących u podłoża różnorodnych ruchów, wspólnot i grup parafialnych jest rzeczą niewątpliwie interesującą. Geneza wszystkich grup parafialnych nie pozostaje bez związku ze zmianą struktur społecznych i uczuciem osamotnienia, jakiego boleśnie doświadcza współczesny chrześcijanin, pomimo podejmowanych wysiłków, aby ożywić życie parafialne i nauczyć się lepiej rozumieć znaczenie Kościoła (79).

Włączenie się człowieka w strukturę wspólnoty wiąże się z problemem identyfikacji.

K. Forster wymienia następujące kryteria identyfikacji:

- publiczne i dostrzegalne uznanie struktury społecznej, która uchodzi za sensowną i godną poparcia,

- akceptacja własnego członkostwa, podstawowe uznanie i wewnętrzne przyjęcie zasadniczych norm jakiejś grupy społecznej,

- proces zmierzający do mniej lub bardziej zgodnej relacji między uznana wspólnotą, a zachowaniami pojedynczego członka.

Religijność (kościelność) może wyrazić się również poprzez integrację z jedną ze wspólnot kościelnych. Bez oparcia się o strukturę grupową nie istnieje praktycznie jakakolwiek kościelność. Parafia, jako wspólnota, jest tym miejscem, gdzie fenomen Kościoła staje się bezpośrednio widoczny (Kirche am Ort), obecny i przeżywany (80). 
Aby zaistniała głęboka więź rodząca wspólnotę należy umożliwić wiernym przeżywanie Kościoła poprzez podejmowanie wspólnych działań. Wspólnota będąca ze swej natury konkretną formą realizacji chrześcijańskiej miłości bliźniego, winna kształtować w nas umiejętność dostrzegania brata w każdym człowieku, wyrabiać zdolność bezinteresownych poświęceń na rzecz innych, uczyć solidarności międzyludzkiej.

Należy też rozwijać duszpasterstwo poszczególnych grup - zespołów, aby w ten sposób wychodzić naprzeciwko ludzkim tęsknotom za prawdziwie chrześcijańskim życiem. W małych grupach nieformalnych istnieje większa możliwość przeżywania autentycznej wspólnoty. Grupy te nie mogą jednak pozostawać w izolacji, żyć tylko dla siebie, dlatego należy je włączyć w całokształt działań prowadzonych przez poszczególne parafie (81).

Kościół włączony w dzieje ludzkości jako instytucja widzialna i ludzka, doświadcza tego samego losu, co świat w którym działa. Dzięki temu zaś, że jest wspólnotą duchową, odgrywa w nim rolę wyłącznie jemu właściwą, jako swoista dusza ludzkiej społeczności (82).

Wypada zaznaczyć, że solidarność z całą ludzkością nie jest wbrew pozorom czymś abstrakcyjnym, lecz przeciwnie realizuje się w określonym środowisku. Człowiek może mówić o swoim poważnym zaangażowaniu wówczas, gdy czuje wspólnotę z innymi ludźmi bez ograniczeń i bez wybierania jej członków, wspólnotę z każdym i ze wszystkimi, ponieważ przeżywa zaangażowanie $\mathrm{w}$ tym co jest najgłębsze $\mathrm{w}$ nas a więc $\mathrm{w}$ tym co jest wspólne we wszystkich. Samotność zbliża człowieka do innych ludzi i wprowadza wspólnotę przeżywania z innymi powszechnej potrzeby. Wspólnota, która w ten sposób powstaje, jest przeżyciem jakby jedynego schronienia, określonej pewności, zagubionych ludzi. Wspólnota chrześcijańska tworzy nieuchronnie - cywilizację miłości.

Wspólnota nie jest nigdy ograniczeniem naszej osobowości. W bycie $\mathrm{z}$ istoty swej zależnym, jakim jest każdy człowiek, wolność zaczyna się zawsze jako akceptacja. Im bardziej ktoś umie przyjąć, tym bardziej się ożywia.

Aby jakiś gest był wspólnotowy, musi być zrodzony z harmonii ze wspólnotą, a nie skierowany ku wspólnemu wynikowi. Każda wspólnota jest utworzona z osób mających często odmienne temperamenty i szczególne umiejętności. Różnorodność życia we wspólnocie rodzi się właśnie z różnorodności darów, jakimi dysponują od samego początku poszczególne osoby, rodzi się więc z różnorodności powołań jej członków.

Jednostki są też funkcją wszczepiania wspólnoty w świat i stąd dają wspólnocie możliwość urzeczywistniania się i rozwoju, bycia skuteczną w realizacji. Wspólnota tym bardziej jest żywa, im bardziej jej członkowie są zdolni do zadań, różnych i wielorakich funkcji (83).

Wielu katolików sądzi, że ich możliwości włożenia swojej cegiełki w budowanie wspólnoty są praktycznie żadne. Prawdziwymi budowniczymi wspólnot Kościoła są osoby, które prawie całą swoją energię wkładają w walkę o odzyskanie samego siebie. Ich zmagania z nałogami, skłonnością do depresji, są takim "wdowim groszem”, który bywa ceniony najbardziej (84).

Ustanowienie wspólnoty (aspekt obiektywny) określić można jako wytworzenie u wszystkich jej członków postawy przynależności (aspekt subiektywny). Postawa taka zdaje się być uzależniona od dwóch czynników: od świadomości wspólnego uzależnienia, czyli solidarności, oraz od aktywnego współuczestnictwa każdego członka wspólnoty. Dla stworzenia prawdziwej wspólnoty należy wzbudzić zbiorowe zachowania wyrażające czynne uczestnictwo dając poczucie solidarności w wykonywaniu wspólnych zadań (85).

Wspólnota Kościoła została przedstawiona w swym uniwersalnym wymiarze jako sakrament, a więc znak i narzędzie jedności istot ludzkich z Bogiem. K. Rahner uwydatnił światowy charakter Kościoła jako wspólnoty (86). 
Kościół współczesny walczy o swoją wspólnotowość. Powrót do pojęcia Ludu Bożego był krokiem w kierunku wspólnoty, choć tylko częściowo udanym, bo nieraz się ono "wichrowało" w życiu praktycznym. W Polsce np. Lud Boży oznacza po prostu "lud wierny", nie Kościół. Jeżeli Kościół ma być rodziną, to musi się realizować w mniejszych wspólnotach, takich gdzie wszyscy się znają. Dlatego podczas soboru pojawiła się koncepcja kościoła jako wspólnoty wspólnot. Może się ona realizować w sposób pluralistycznie swobodny, lub bardziej zorganizowany poprzez podział parafii na mniejsze wspólnoty podstawowe (87).

\section{2. 3. Rodzaje wspólnot religijnych}

Z biografii wielkich założycieli religii dowiadujemy się, że zgodnie z decydującym doświadczeniem religijnym, interpretowanym przez nich jako wezwanie, w pewnym okresie swego życia zaczęli oni skupiać wokół siebie uczniów. Grupa, którą mąż Boży skupia wokół siebie, może być luźnym zespołem, albo zwartą jednostką społeczną, związaną wspólnymi doświadczeniami religijnymi, której istotę objawia i interpretuje założyciel. Wzrastające poczucie solidarności wiąże członków ze sobą i odróżnia od wszelkich innych form organizacji społecznej. Grupę taką można nazwać kręgiem, co ma podkreślić fakt, że jest ona zorientowana ku pewnej postaci centralnej, z którą każdy z uczniów pozostaje w bliskim kontakcie. Członkostwo $\mathrm{w}$ takiej grupie może wymagać zerwania $\mathrm{z}$ dotychczasowym, zwykłym trybem życia i radykalnej zmiany stosunków społeczno - religijnych. Więzy rodzinne i pokrewieństwa na pewien czas zostają zerwane lub rozluźnione. Krąg nie jest zorganizowany w ścisłym tego słowa znaczeniu, lecz rozmaitość indywidualności i różnice wieku są zwiastunami przyszłej dyferencjacji funkcji członków.

Najbliższym kryzysem, oznaczającym narodziny nowej epoki w rozwoju rodzącej się religii i powodującym jej przekształcenie strukturalne, jest śmierć założyciela. Osobiste uczniostwo, pierwotny warunek sine qua non, nie może być nadal warunkiem chociaż autorytet i prestiż pozostałych uczniów znacznie wzrasta. Środek ciężkości leży teraz w nowej nauce, w nowej postawie, nowym duchu i nowej tradycji, które zmarły założyciel pozostawił. Założyciel staje się przedmiotem kultu. Wiara i ufność w niego i jego misję staje się kryterium członkostwa w grupie, która przestaje być kręgiem uczniów, a staje się gminą pierwotną (brotherhood). Te nowe jednostki socjologiczne różnią się interpretacją własnej istoty i roli. Organizacja centralna i lokalna są w ciągłej ze sobą zwadzie, jedna potrzebuje drugiej. Członkostwo w gminie pierwotnej jest początkowo natury bardziej duchowej, niż organizacyjnej, jednakże tendencja do organizacji istnieje zawsze i ujawnia się w pewnym stopniu nawet w kręgach uczniów. Gmina pierwotna jest podobna do kręgu uczniów ze względu na charakter duchowy i charyzmatyczny. W jej obrębie istnieje swoboda i prostota, nie istnieją żadne wyraźne rozdziały i ograniczenia. Występuje też łatwość przyjmowania nowych idei, wrażeń i wpływów. Dominuje nadal prestiż wielkich przywódców charyzmatycznych (Apostołów), który dopiero stopniowo zaczyna słabnąć. Czynnikiem scalającym i jednoczącym gminę pierwotną jest bardziej kult niż doktryna. Charyzmat i seniorat stają się po pewnym czasie niewystarczające jako podstawa autorytetu. Rozpoczyna się reorganizacja, ustanawia się dyscyplinę i tak kończy się okres gminy pierwotnej. Zastępuje ją nowy typ organizacji, forma kościelna (ecclesia). Tradycja ustna zostaje spisana, dokładnie sformułowana reguła i tradycja Kościoła, od tej pory wszelkie rozbieżności poglądów w stosunku do nauki oficjalnie przyjętej uważane będą za herezję (88).

Wewnątrz formacji kościelnej istnieją tworzone grupy, dla zaprotestowania przeciw jej polityce, przeciwko kompromisowości i rozluźnieniu, które uważa się za zgubne. Motto ich brzmi: ecclesia in ecclesia. Zjawiskiem pośrednim między protestem indywidualnym, a 
całkowitą separacją grupy, która nie utożsamia się ze społecznością idealną, ani nie usiłuje ukonstytuować się jako specjalna jednostka w ramach grupy są tzw. collegia pietatis. W tych collegiach podejmuje się próby powrotu do początkowego doświadczenia w celu odzyskania natchnienia założyciela i jego kręgu. Tendencję tę i jej następstwa egzemplifikuje koncepcja filadelfijska, powołująca się na idealną społeczność z Apokalipsy św. Jana. Siłą napędową ruchu religijnego może być pragnienie intensywniejszego doświadczenia religijnego, albo maksymalnej standaryzacji wspólnych praktyk religijnych. Wspólne doświadczenia i postawy oraz ideały łączą ludzi ze sobą. Początkowo może wystarczyć paralelizm religijnej spontaniczności. Jest to zwykle pierwszy krok ku bliższemu związaniu się tych, których łączy protest przeciwko status quo, oraz wspólne pragnienie odnowy i uintensywnienia centralnego doświadczenia religijnego. Jeśli grupy te są w sposób widoczny zintegrowane raczej przez ducha niż przez silną organizację, zajmują często postawę liberalną i krytyczną wobec doktryny i praktyki grup głównych, manifestują swoją obojętność, bądź opowiadają się za poglądami swoistymi, jeżeli nie heretyckimi. W bractwach tego rodzaju, pewnemu minimum organizacji towarzyszy zwykle odpowiednio egalitarna koncepcja braterstwa. Jednak wraz z początkami rozwarstwienia i specjalizacji funkcji, fraternitas przechodzi w etap następny. Trzeci typ reakcji wobec tendencji eklezjastycznej skłania się ku ściślejszej i bardziej rygorystycznej koncepcji społeczności w ramach głównej organizacji. Grupę monastyczną (zakonną), można określić jako kongregację założoną i zorganizowaną, składającą się z tych, którzy z powodu swego protestu postanowili prowadzić życie poświęcone religijnej pobożności, w bliższym powiązaniu, niż jest to możliwe w ramach fraternitas. Ideał pojmuje się tutaj w kategoriach pierwotnego, centralnego doświadczenia religijnego. Absolutne posłuszeństwo, stała rezydencja, swoisty ubiór, specjalne akty pobożności oraz wspólna praca łączą członków konwentu (zakonu). Jednoczy ich także (w negatywnym sensie) wspólne wyrzeczenie się własności i świeckich obowiązków. Monastycyzm, jest dynamicznym ruchem, posiadającym swoje wzloty i upadki. Wydaje się, że w człowieku istnieje głęboko zakorzeniona tendencja do łączenia się z innymi ludźmi w czci i czerpania otuchy oraz zadowolenia stąd, że dzielą się z innymi tym co posiadają. Wiara w wartość takiej wspólnoty była w dziejach ludzkości tak głęboka, że wytworzyła niektóre z najsilniej oddziałowujących pojęć i instytucji socjologicznych i religijnych. Dzięki takim wyobrażeniom dochodzi nie tylko do integracji pierwszych wyznawców, inspirowanych przez nowe doświadczenie, lecz i do stałego wspomagania grupy wtedy, gdy okazuje się konieczna jej reintegracja (89).

Ograniczoność fizyczna skazuje człowieka na pozostawanie $\mathrm{z}$ innymi ludźmi $\mathrm{w}$ ścisłych związkach i korzystanie z ich pomocy. Mamy dwie zasadnicze racje wiązania się osób ze wspólnotą. Jedna z nich wypływa z dynamiki twórczej człowieka, z jego moralnych i poznawczych związków ze światem kultury, nauki, czyli ze światem wartości duchowych. Druga natomiast dotyczy fizycznej niewystarczalności człowieka. Konieczność życia społecznego w kontekście tych rozważań odsłania wewnętrzne (tkwiące w naturze człowieka) odniesienia do innych osób i do odpowiedniego układu dóbr. Wykrywamy w ten sposób w naturze ludzkiej elementy trojakiej wspólnoty:

- wspólnotę potrzeb, wypływającą z jej z ograniczoności,

- wspólnotę działania, uwarunkowaną jej twórczą dynamiką,

- wspólnotę dóbr i wartości, celem wzajemnego uzupełniania się (90).

Pomiędzy osobą ludzką, a społecznością istnieje wzajemna, głęboka zależność, która się wyraża w tym, iż osoba ludzka jest i powinna być zasadą, podmiotem i celem wszystkich 
urządzeń społecznych, ponieważ ze swej natury koniecznie potrzebuje ona życia społecznego (91).

Kościelna wspólnota, uczy Papież w adhortacji "Christifideles Laici”, jest jednością organiczną, analogicznie do jedności żywego i sprawnego ciała. Odznacza się ona w istocie współistnieniem wielorakich powołań i stanów, tajemnic i charyzmatów, zadań, które choć różne, są $\mathrm{w}$ stosunku do siebie komplementarne. Ta różnorodność i komplementarność sprawia, że każdy świecki pozostaje w relacji do całego ciała i sam wnosi do niego własny wkład, a wszystko to, co go wyróżnia nie jest większą godnością lecz specyficzną dla niego, komplementarną zdolnością do służenia. Tak więc charyzmaty, urzędy, funkcje, posługi świeckiego katolika istnieją we wspólnocie i dla wspólnoty. Wspólnota Ludu Bożego otrzymuje od Boga niezwykłe bogactwo charyzmatów. Obecność we wspólnocie parafialnej lektora, akolity i kantora, jako trzech równorzędnych posług ministeriów dla osób świeckich katolików, byłaby swego rodzaju przełożeniem eklezjologii na język praktyki duszpasterskiej. Każdy z nich bowiem byłby odpowiedzialny za konkretny wymiar życia wspólnoty parafialnej (wymiar nauczania, ewangelizacji, wymiar miłosierdzia - wyzwolenia, wymiar jedności - świętowania). Prowadziłby również konkretne małe wspólnoty, z którymi mógłby spełniać powierzone mu zadania. W liturgii zaś spełniałby funkcje, które wyrażają jego zadania w codziennym życiu wspólnoty. Hierarchiczność nie jest uboczną cechą Kościoła lecz stanowi jego istotny wymiar. Oparta jest na zasadzie zróżnicowania posług we wspólnocie wiernych. Aktualną sytuację można by określić słowami: "w Kościele jest hierarchia" nie zaś "Kościół jest hierarchiczny". Hierarchiczność bowiem dotyczy jednego promila członków wspólnoty. W ramach hierarchii Kościoła istnieje dwojaki rodzaj posług: pasterskie i diakonijne. Ten dychotomiczny podział może zostać odzwierciedlony we właściwym wymiarze w posługach - ministeriach przeznaczonych dla świeckich. Dwie spośród nich mogą mieć charakter przewodniczenia całej wspólnocie (moderator i animator), trzecia ma charakter pomocniczy i może być posługą np. ceremoniarza. Chodzi tu oczywiście o poszerzone rozumienie pojęcia ceremoniarz, obejmujące funkcje liturgiczne i adekwatne do charakteru tych funkcji codzienne zadania w życiu wspólnoty (92).

Wspólnota polityczna i wspólnota religijna, każda w swej dziedzinie powinny zachować niezależność i autonomię. Autonomia oznacza, że nie ma mowy o strukturalnej łączności, czy też jakiejkolwiek innej nierówności wobec prawa ze względów wyznaniowych. Autonomia nie oznacza jednak separacji, czy też przeciwstawiania obu tych wspólnot. Życie publiczne nie może być sferą zamkniętą dla misji Kościoła. Nauczanie religii w szkołach państwowych zgodnie z zasadą dobrowolności jest prawem Kościoła. Rzecz jasna, powinno ono dotyczyć również niekatolików i ich związków wyznaniowych (93).

Kościół jest komunią - powiedział Paweł VI, przemawiając do wiernych na zakończenie Vaticanum II. Synod Nadzwyczajny z 1985 r. przypomniał - eklezjologia komunii jest ideą centralną $w$ dokumentach soborowych. Kościół jako mistyczne ciało Chrystusa, o tyle jest Jego prawdziwym znakiem, na ile jest wspólnotą (communio). To oznacza przede wszystkim wspólnotę wierzących, zgromadzenie osób przyjmujących objawienie Boże i przekonanych, że w Kościele stały się one społecznym podmiotem wiary. Ową rzeczywistość społeczną, składającą się $\mathrm{z}$ wielu osób uzewnętrznia wiara poszczególnych członków. W Kościele wierni stanowią wspólnotowy podmiot wiary w Boga. Wspólnota Kościoła powinna być skierowana ku dobru poszczególnych jednostek stanowiących Kościół. Poszczególne jednostki poprzez przynależność do wspólnoty kościelnej otrzymują wymiar historiozbawczy własnej wiary. W takim kontekście jawi się wyraźniej wartość chrztu, jako sakramentu wiary. Przez chrzest człowiek zostaje włączony do wspólnoty Kościoła, aby w niej rozwijać swoją wiarę i osiągnąć dojrzałość. Komunia 
Kościoła przybiera zewnętrzną postać w kościołach lokalnych (diecezjach i parafiach). Kościoły lokalne manifestują i uzewnętrzniają komunię Kościoła powszechnego, dają też oparcie komunii w innych pomniejszych wspólnotach kościelnych. Eklezjologia komunii uświadamia pasterzom Kościoła konieczność powierzania świeckim tych funkcji, urzędów i posług, które lepiej podkreślają ich miejsce w Kościele. W tym kontekście nie sposób nie wspomnieć o niepokojącym zjawisku rosnącej liczby sekt w Polsce postkomunistycznej. Katolicy Polscy nie będą szukać wschodnich metod osiągnięcia pokoju wewnętrznego, jeżeli w wychowawczych instytucjach Kościoła i katechezie zostanie położony większy nacisk na medytację, kontemplację, rachunek sumienia i inne bogate formy duchowości chrześcijańskiej. Należy postulować rozwój i odnowę rekolekcji, zwłaszcza zamkniętych, pielgrzymek i dni skupienia. Rozwój sekt nie może spotkać się z łatwym i prostym potępieniem, ale raczej pobudzić do formowania we wspólnotach diecezjalnych, parafialnych i innych małych grupach w Kościele, wspólnot odnowy katechumenalnej, biblijnej i rodzinnej, w których dokonuje się przejście od anonimowości i przerostów administracyjnych w stronę chrześcijaństwa wspólnotowego, wyraźniej ożywianego przez Chrystusa. Na żywy Kościół składają się bowiem wzbogacające się nawzajem wspólnoty parafialne, formacyjne, charytatywne, modlitewne, rodzinne, duszpasterstwa zawodowego itp. Dewiacje pojawiające się w pewnych fazach rozwoju tych grup i ruchów, nie mogą stanowić argumentu przeciwko kształtowaniu modelu Kościoła jako wspólnoty wspólnot ewangelizowanych i ewangelizujących. Należy położyć szczególny nacisk na tworzenie organizacji młodzieży katolickiej, odnowę i rozwój istniejących ruchów i duszpasterstw młodych w celu ochrony młodego pokolenia przed nihilizmem i pomieszaniem wartości. Należy także wyakcentować sprawę reformy liturgicznej ze szczególnym uwzględnieniem wymiaru wspólnotowego liturgii (94).

J. Majka wymienia sześć elementów koniecznych do zaistnienia parafii jako wspólnoty i grupy społecznej. Parafia jako część integralna Kościoła stanowi tutaj podstawę, zaś pozostałe elementy to: władza proboszcza nad wiernymi, struktura socjologiczna (morfologia i ekologia) parafii, aspekty społeczno - gospodarcze, struktura formalno- organizacyjna oraz struktura faktycznego stanu religijności w parafii (95).

Każda parafia stanowi dość skomplikowany obraz rozwarstwień majątkowych, społeczno - organizacyjnych itp., które korelują w określony sposób ze strukturą faktycznej religijności, z jej stopniem i typem, a także ze stanem moralności parafian. W obrębie parafii powstaje wiele trwałych więzi społecznych: sąsiedzkie - ponieważ parafia rozwija swoją działalność na ściśle określonym terytorium, jako społeczność lokalna, poczucie wspólnoty ukształtowane religijnymi rytuałami i symbolami, a przede wszystkim doktryną, propagującą wspólny dla wszystkich cel - wizję życia egalitarnego po śmierci. Pod względem zewnętrznym wspólnotę parafialną wyraża częstotliwość spotkań jej członków w kościele oraz obowiązkowe spełnianie nakazanych prawem kanonicznym praktyk religijnych (96).

Kościół jest wspólnotą wszystkich ochrzczonych, tzn. tych, którzy na mocy chrztu stali się uczestnikami posłannictwa Chrystusa: kapłańskiego, prorockiego i królewskiego. Wspólnota wierzących (communio fidelium) oparta na chrzcie ma bezpośredni związek z Eucharystią. Z tej to wspólnoty wyrasta inna wspólnota między wszystkimi członkami Kościoła (communio inter Ecclesias). Kościelna wspólnota katolicka realizuje się na trzech poziomach: Ecclesia universalis (kościół powszechny), ecclesia localis (kościół lokalny) i ecclesia particularis(kościół partykularny). Słowo Kościół w konotacji posoborowej oznacza wspólnotę wiernych obejmujących zarówno pasterzy jak i osoby świeckie (97).

Gdy zważymy na nową polską sytuację społeczną i związane z nią nadzieje oraz niepokoje, nieodparcie narzuca się pytanie o dzisiejszą misję Kościoła, w kształtowaniu 
nowej przyszłości. Nie to zatem, wbrew domysłom wielu, jest w tej chwili ważne, czy zachodzące zmiany w Polsce sprzyjają Kościołowi, czy raczej niosą dla niego zagrożenie, lecz to z jakim obliczem Kościół przystąpi do budowy wspólnego jutra Polaków, jak będzie jego oferta ludzkiej obecności w świecie i jakie nade wszystko będzie świadectwo, niezależnie od pomyślnych lub niepomyślnych warunków zewnętrznych i stanu wnętrz ludzkich. W tym względzie sprawa parafii, jako pewnej charakterystycznej postaci współbycia chrześcijan i urzeczywistniania życia według Ewangelii na polskim gruncie odżywa i nabiera niepomiernego znaczenia. Właśnie od kształtu parafii czyli od jej autentyzmu $\mathrm{w}$ poważnej mierze zależeć będzie udział chrześcijaństwa $\mathrm{w}$ przeobrażaniu bardzo zdeprawowanych u nas wzajemnych odniesień człowieka do człowieka, także wiarygodność chrześcijańskiej hierarchii wartości moralnych (98).

Wspólnotowy charakter powołania każdego chrześcijanina i jego prymat nad powołaniem indywidualnym, pozwala na tworzenie Kościoła. Relacja między powołaniem wspólnotowym, a indywidualnym układa się w dwojaki sposób, podobnie jak między wspólnotą kościelną, a jej członkami. Jednostka ludzka nie ginie, nie traci swej samoistności choć bez niej nie może istnieć. Każdy członek wspólnoty w pewnym sensie ujawnia ją i reprezentuje, a jego powołaniem jest urzeczywistniać to, co stanowi prawdziwe dobro wspólnoty (99).

Jan Paweł II mówi, że obraz konkretnego człowieka w jego relacji do Boga byłby niepełny, a nawet fałszywy i niezgodny z nauką Kościoła, gdybyśmy nie dostrzegali jego miejsca we wspólnocie, w całym szeregu wspólnot, które są jego tworem, określając go w jego konkretnym istnieniu i warunkując realizację jego celów. Mówiąc o wspólnocie mamy na myśli wszystkie rodzaje i formy wspólnot. Pierwszą jest, jako wspólnota podstawowa, rodzina. Ona posiada i wyzwala ogromną energię potrafi wyrwać człowieka z anonimowości, podtrzymać w nim świadomość godności własnej osoby, wzbogacić jego odrębność i niepowtarzalność oraz włączyć ją w tkankę społeczeństwa. Rodzinę przedstawia papież jako komunię osób, ukazując cały zespół międzyosobowych relacji, które ją kształtują: oblubieńczość, ojcostwo, macierzyństwo, synostwo, braterstwo. Drugą oprócz rodziny wspólnotą do której papież przywiązuje ogromną wagę jest naród. Jest on rozumiany jako wspólnota kulturowa i kształtująca człowieka dzięki temu, że jest on podmiotem kultury. We wszystkich wspólnotach niezależnie od szczebla istotną rolę odgrywa osoba. Dlatego właśnie kształt wspólnot, począwszy od rodziny, aż po naród ma tak wielkie znaczenie dla całej ludzkości, dlatego też papież tak zdecydowanie i uparcie walczy o prawa rodziny i narodu (100).

\section{2. 4. Elementy konieczne do powstania wspólnoty religijnej}

W dniu 8 czerwca 1991 r. papież dokonał otwarcia Drugiego Synodu Plenarnego w Polsce. Postulaty pierwszego dokumentu Synodu dotyczą czterech, jak się wydaje, najważniejszych zadań Kościoła $\mathrm{w}$ dobie przejścia do demokratycznego modelu życia społeczno - ekonomicznego: określenie miejsca Kościoła w państwie demokratycznym, pogłębienie katolicyzmu masowego, odnowy świadomości etycznej i urzeczywistniania Kościoła jako wspólnoty. Synod podkreśla, że w Polsce należy dołożyć starań o zachowanie i odnowę tak cennych form ewangelizacji wspólnot parafialnych jak np. misje czy rekolekcje. Istotną rolę może odegrać, w dziele pogłębiania katolicyzmu, katecheza dorosłych oraz formacja teologiczna osób świeckich. Kościół jest wspólnotą wspólnot ewangelizujących i otwartych na ewangelizację. Jako postulat potraktowano promowanie wizji Kościoła jako komunii wspólnot rodzinnych, parafialnych, formacyjnych, modlitewnych, charytatywnych, duszpasterstw zawodowych i innych. W ten sposób można przeciwdziałać rozwojowi sekt 
oraz uchronić życie parafialne od przerostów administracyjnych. Musi iść z tym w parze ożywienie działalności rad parafialnych i duszpasterskich na poziomie diecezjalnym i parafialnym oraz odnowa istniejących grup, ruchów, duszpasterstw ludzi młodych i tworzenie katolickich organizacji młodzieżowych (101).

Wspólnota jest miejscem przynależności, które traktujemy jako naszą ziemię, w której odnajdujemy naszą tożsamość. Osoby należące do danej grupy, czy wspólnoty rozpoznajemy po ich sposobie ubierania się, symbolach, żargonie i szczegółach identyfikacyjnych. Odnosimy więc wrażenie, że fakt tworzenia wspólnoty budzi potrzebę symbolu podkreślającego przynależność do niej. Wspólnota jest miejscem, które otwiera na innych. Wspólnota tym różni się od grupy przyjaciół, że jej członkowie sami określają warunki przynależności i więź łączącą, charakteryzują swe cele, a także jednoczącego ich ducha. Wspólnie uznają, że są wzajemnie za siebie odpowiedzialni. Grupa przyjaciół również może przekształcić się we wspólnotę, jeżeli będzie w niej wzrastało poczucie przynależności, jeżeli otworzy się na innych, jeżeli jej członkowie stopniowo zaczną czuć się za siebie odpowiedzialni. Wspólnotę, której członkowie żyją w prawdziwym poczuciu przynależności do niej, cechuje otwartość, umiejętność przyjmowania i słuchania innych osób. Życie wspólnoty czerpie inspirację $\mathrm{z}$ tego co uniwersalne, a także $\mathrm{z}$ prawdziwości, czy realnychzasad. Wspólnota przyjmuje to, co uniwersalne, opiera się na przebaczaniu i otwartości na tych, którzy są odmienni, na ubogich i słabych.

Sekty tworzą wokół siebie mury i bariery ze strachu, a także z potrzeby dowartościowania siebie, stworzenie sobie fałszywego poczucia bezpieczeństwa. Żyć we wspólnocie, to znaczy burzyć bariery, z myślą o tym, by przyjąć odmienność drugiego człowieka. Wspólnota jest miejscem wzajemnej miłości. Definiują wspólnotę trzy elementy: wzajemna miłość, więź łącząca wszystkich jej członków i poczucie misji do spełnienia. We wspólnocie miłością darzymy każdą konkretną osobę, a nie wspólnotę w sensie abstrakcyjnym, rozumianą jako całość (instytucję czy sposób na życie). Liczą się osoby. Wspólnoty nigdy nie powinna przytłaczać liczba stanowiących ją osób. Jest ona przecież podporządkowana tym osobom, ich zdolnościom rozwoju. Prawdziwa wspólnota zaczyna się wówczas, gdy jej członkowie przestają się przed sobą ukrywać, gdy nie usiłują za wszelką cenę dowieść swojej prawdziwej lub domniemanej wartości. Gdy znikają dzielące nas bariery możemy doświadczać komunii. We wspólnocie wszyscy są wezwani do współpracy. Czynności związane z życiem codziennym muszą być wykonane. We wspólnocie potrzebna jest więc dyscyplina i bardzo konkretna organizacja. Ich brak doprowadza do chaosu i poczucia zupełnej nieskuteczności. Wspólnota stanowi przede wszystkim miejsce komunii. Dlatego też w codziennym świętowaniu podkreślić należy takie realia, symbole, spotkania, chwile świętowania, które rozbudzają świadomość łączności. Gdy wspólnota staje się tylko miejscem pracy, grozi jej poważne niebezpieczeństwo. Wspólnota jest miejscem uzdrowienia i pokoju. W każdej wspólnocie tkwi pragnienie łączności z innymi, wołanie o miłość, zrozumienie, lęk przed sądem czy potępieniem. Różnice między wspólnotą, a grupą zdeterminowaną, taką czy inną ideą polega na tym, że tego typu grupa jest gotowa widzieć nieprzyjaciela $\mathrm{w}$ człowieku przychodzącym z zewnątrz. Walka zwrócona jest na zewnątrz i z walki tej wyjdzie zwycięzca i pokonany. Grupa wie, że posiadła prawdę, że ma rację, toteż stara się ją narzucić. Wspólnota wie, że walka toczy się we wnętrzu każdej osoby i wewnątrz wspólnoty, że powinna zostać skierowana przeciwko wszelkiej formie pychy, elitaryzmu, nienawiści, czy depresji. Są to wrogowie, którzy ranią i niszczą ludzi, wprowadzają podziały, wywołują wojny. Wróg kryje się wewnątrz nie na zewnątrz. Wspólnota jest przy tym miejscem przebaczenia. Przebaczać, to nie tylko powiedzieć osobie, która wpadła w złość, czy też pozwoliła sobie na antywspólnotowe zachowanie: "Ja $\mathrm{Ci}$ przebaczam". Jeżeli 
posiadamy pewną władzę, mocną pozycję we wspólnocie łatwo manipulować przebaczeniem. Przebaczyć, to zrozumieć, co kryje się za tą słabością, co drugi człowiek chce dać innym do zrozumienia. Może wspólnota jest zbyt sztywna, legalistyczna, skostniała w swoim sposobie myślenia, może brak w niej prawdy i miłości. Przebaczyć, to także uznać na nowo przymierze łączące nas $\mathrm{z}$ tymi, z którymi nie możemy się zrozumieć, znaczy to otworzyć się na nich, na nowo ich wysłuchać (102).

Według G. Marcela człowiek jest pielgrzymem (homo viator). Jego życie ma się realizować w twórczej miłości. Koncepcja wspomnianego autora pozwala umieścić religijność człowieka w kontekście jego osobowej autorealizacji. Religijność może być rozpatrywana $\mathrm{w}$ kategoriach komunikacji interpersonalnej. Istotne jest uwzględnienie warunków tej komunikacji, a więc wezwania i dysponowalności. Zaangażowanie i twórcza wierność są znaczącymi wymiarami życia religijnego. Ważny jest też związek wiary i miłości (komunia osób) w kontaktach ludzi z Bogiem (103).

Fundamentalna staje się edukacja od rodziny, poprzez wspólnoty, dzieła i ruchy młodzieżowe, ponieważ ma decydujące na całe życie znaczenie. Rozbicie poprzez totalitaryzmy dorobku polskiego $\mathrm{w}$ tym zakresie musiało przynieść m.in. to co dziś mamy. Odbudowa w nowych warunkach, w nowym stylu zgodnie $\mathrm{z}$ dzisiejszymi potrzebami różnych ruchów, służb i dzieł, musi mieć fundamentalne znaczenie. Ważną rzeczą jest wykorzystanie najciekawszych doświadczeń polskich i zagranicznych. Mają je przecież dobre i żywotne wspólnoty parafialne (zachodnie) ostatnich lat. Od wieków wspólnoty zakonne odpowiadać miały w szczególny sposób na potrzeby wykraczające poza podstawowe ramy duszpasterstwa parafialnego. Stara tradycja kościelna zostawiała tym wspólnotom daleko idącą autonomię, by mogły realizować swój własny tryb życia, zgodnie ze swoistym powołaniem. Obecnie coraz bardziej wtapiają się one w ramy struktur parafialno - diecezjalnych. Oznacza to w prostej drodze zubożenie propozycji do katechezy parafialnej i brak odpowiedzi na potrzebę głębszych przeżyć duchowych oraz mistycznych u ludzi młodych (104).

Człowiekowi, jako osobie, w każdej wspólnocie państwowej przysługują niezbywalne prawa (do prawdy, dobra, życia, rozwoju osobowego, pracy i własności). Szczególnym podmiotem praw jest rodzina, która powinna mieć zagwarantowaną swobodę wychowania potomstwa, zgodnie z przekonaniami religijnymi. Na wspólnocie państwowej ciąży obowiązek zapewnienia praw przysługujących wspólnocie narodowej, rodzinnej i religijnej. Zapewnienie tych praw jest warunkiem powodzenia w urzeczywistnianiu przez władzę własnych programów (105).

W każdej parafii powinno działać wiele organizacji i ruchów kościelnych. Mała wspólnota powinna być podstawowym miejscem realizacji człowieka i jego powołania chrześcijańskiego. Nie powinna nim być jakaś organizacja. Przynależność do niej jest pomyślana jako wezwanie do rozwoju osobistej świętości w służbie dla potrzeb całej grupy i parafii. Najbardziej widocznym przejawem życia wspólnoty jest wspólne świętowanie, wspólne zaradzanie problemom, albo solidarność w nieszczęściach. Inni ludzie przyglądając się z boku będą pragnąć się do nich przyłączyć (106).

Młodzi ludzie lubią podróżować i wędrować do różnych miejsc z dala od domu, pragną być razem we wspólnocie. Dlatego pielgrzymki, które oni odbywają są odzwierciedleniem drogi ich życia (107).

Problem świeckich w Kościele nie może być rozwiązany w sposób płytki poprzez znalezienie dla świeckich kilku miejsc i sposobów zaangażowania w ramach wspólnot, ale musi prowadzić do głębokiego przeobrażenia Kościoła w duchu teologii laikatu. Należność do Kościoła, to znaczy tworzyć communio, czyli wspólnotę osób wierzących, które się 
wzajemnie obdarowują. Chodzi o to, by każda parafia i cały Kościół przemieniał się we wspólnotę braci i sióstr, którzy razem podejmą czynną odpowiedzialność za Kościół. Szczególnym miejscem, choć nie jedynym, realizacji tego zadania pozostaje parafia. Papież mówiąc o wielkiej liczbie świeckich zaangażowanych w dzieło Synodu Plenarnego, wskazał na to, iż jest to zapowiedź większego zbliżenia wspólnot parafialnych do ideału chrześcijańskiej communio, takiej wspólnoty, w której nikt nie jest biernym odbiorcą darów, bo wszyscy starają się dać coś z siebie, wspólnoty, za którą czują się odpowiedzialni. Do kształtowania się tego nowego modelu bycia razem, bycia członkiem wspólnoty parafialnej z pewnością przyczynić się mogą rady duszpasterskie (108).

Jednostka ludzka, która ma większe możliwości zaspokojenia potrzeb we wspólnocie, z zadowoleniem włącza się w życie wspólnoty, integruje się z tą wspólnotą. Jednostka, której wspólnota wydaje się mało atrakcyjna, szuka zaspokojenia swych potrzeb w środowisku pracy zawodowej, stawiając wyżej to środowisko, bowiem umożliwia ono zawieranie nowych kontaktów interpersonalnych. Czynnikami dezintegrującymi wspólnotę są sztywne warunki (struktury psychiczne). W dużych wspólnotach integracja jest bardziej ukierunkowana na cele wspólnoty, w mniejszym stopniu uwzględniając cele poszczególnych jednostek. Podział pracy zwiększa zróżnicowanie ról oraz ich specyficzność wyrażającą się w zawężającym się zakresie oczekiwań związanych $\mathrm{z}$ pełnioną funkcją. Struktura takiej wspólnoty sprzyja raczej ruchliwości społecznej jednostki zarówno w skali przestrzennej jak i pozycji społecznej. To z kolei osłabia związki jednostki ze wspólnotą, do której jednostka integralnie należy. Otwartość wspólnot sprzyja nowym porównaniom i integracji oraz zwiększa widoczność normy i stylu życia (109).

W rzeczywistości określenie wspólnota nie pokrywa się z określeniem parafia. Wspólnota jest raczej drogą odkrywania misterium Kościoła, a zarazem środowiskiem kształtowania się identyfikacji chrześcijanina i jego dojrzałej wiary. Uznaje się obecnie konieczność odniesienia terytorialnego, jak i instytucjonalnego, $\mathrm{z}$ równoczesnym uwzględnieniem postulatu budowania prawdziwych wspólnot na miarę człowieka, by parafia mogła stać się wspólnotą wspólnot. Wymiar wspólnotowy przekazu wiary i życia chrześcijańskiego nie jest problemem tylko naszych czasów. Występował on we wszystkich etapach historii Kościoła, jakkolwiek formy tej wspólnoty były bardzo różne w zależności od konkretnej sytuacji społeczności ludzkiej. Szybki proces urbanizacji społeczność kościelną stawia pod znakiem zapytania, jak i dotychczasowe formy współżycia w ramach parafii terytorialnej (110).

Im więcej form wspólnotowych i grup, tym bardziej zmniejsza się rozbicie i zatomizowanie parafii. W miejsce pustki i indyferentyzmu wchodzi konkretny cel, a skupienie się wokół tego celu jest wsparte przez wiarę i etykę chrześcijańską, wpływa na jego sublimację, również na pogłębienie wiary, poszerzenie jej horyzontów (111).

Świadomość wspólnoty podtrzymuje codzienna modlitwa jednych członków za drugich. Wspólnotę religijną nie tworzy jednak tylko modlitwa i wspólne praktyki, lecz rozmowy i wspólne spotkania. Rozmowa przezwycięża naturalną skłonność do zamykania się $\mathrm{W}$ sobie. Każdą wspólnotę $\mathrm{z}$ zasady powinna cechować radość. Chrześcijańskie "głupstwo" zamienia się w radość wspólnej wiary i wspólnoty, która trwa, dopóki strzeże wiernie tajemnicy życia w prawdzie. Im wyższe cele stawia sobie wspólnota, tym większą uwagę musi zwracać na zachowanie należytych form w stosunkach międzyludzkich (112).

G. Gurvitsch nadał odmienne znaczenie terminowi wspólnota. Fakty społeczne stanowią jego zdaniem akty świadomości. Z aspektu psychologii społecznej wyróżnia się trzy fazy uspołecznienia, w zależności od stopnia uświadomienia: masę, wspólnotę i komunię. W masie świadomości nie przenikają się wzajemnie, mają jedynie styczność powierzchowną. 
We wspólnocie natomiast świadomości mają kontakty typu przenikających się okręgów. W komunii osiągają najwyższy stopień wzajemnego przenikania się. "Ja" zostaje całkowicie zastąpione "my". Demokracja do której dąży między innymi wiele ruchów politycznych o odcieniu chadeckim, zakłada demokratyzm typu wspólnotowego. Przedmiotem akcji politycznej nie jest jednostka lecz wspólnota. Państwo według tych idei powinno reprezentować wspólnotę polityczną oraz postulować wspólnotę ekonomiczną. Wyraża także pogląd, iż narody powinny stać się wspólnotą ekonomiczną. Wyraża także pogląd, iż narody powinny stać się wspólnotą międzynarodową. Uczestnictwo ludu w codziennym funkcjonowaniu wspólnoty jest w konsekwencji koncepcją demokracji opartej na personalizmie. Jest ono wynikiem uznania we wspólnocie spontanicznej formy uspołecznienia opartej na zasadzie miłości drugiego człowieka (113).

Po zniknięciu zagrożenia z zewnątrz Kościół musi swoim wiernym, czyli katolikom świeckim, udziela odpowiedzi w sprawach wiary i moralności, które uwypuklają dojrzalszą, bardziej refleksyjną i moralną dorosłość jednostki. W przeszłości Kościół nie był krytykowany, bo musiał być ostoją wolności dla przeciwników narzuconej władzy politycznej oraz strażnikiem narodowych interesów, by nie dopuścić do ich zagłady. Polski Kościół nie przekształcił się jeszcze w otwartą dialogową wspólnotę. To co nowe musi znaleźć jakieś miejsce związków i organizacji to dla Kościoła sprawa niezbędna, ale jednocześnie wśród duchowieństwa kryją się obawy, że te organizacje czy ruchy katolików nazbyt mogą się usamodzielnić, oderwać od Kościoła instytucjonalnego i tradycyjnego duszpasterstwa. $Z$ drugiej strony katolicy świeccy jeszcze nie rozumieją, że nadeszła ich godzina. Mają niewystarczającą wiedzę o swoich zadaniach i zaangażowaniu w Kościół, świat (114).

Rzeczywistość communio wynika $\mathrm{z}$ wielości powołań, a zarazem stwarza niejako przestrzeń, w której one mogą się prawidłowo realizować. Stanowią one o Kościele wspólnocie jednocześnie go tworząc. Communio oznacza stały immanentny dynamizm wspólnoty, który od wielości i złożoności prowadzi do jedności.

W obecnych czasach, gdy miasta są bezosobowe i pozbawiają osobowości, wielu ludzi poszukuje wspólnoty. Szczególnie są osamotnieni, zmęczeni, słabi i smutni. dla wielu samotność jest nie do zniesienia, daje przedsmak śmierci. Wspólnota jest wtedy cudownym miejscem (zjawiskiem), gdzie każdy dzieli swe życie z innymi. Wspólnota inaczej patrząc jest też czymś strasznym. Odkrywamy uczestnicząc w niej własne ograniczenia i egoizm. Jeśli jednak zgodzimy się na obecność tych wszystkich potworów w nas, możemy je poznać i nauczyć się je oswajać. Tak będziemy dążyć do wyzwolenia się od nich. Wspólnota staje się nią dopiero wtedy, gdy większość osób ją tworzących przechodzi od etapu "wspólnota dla mnie" do etapu "ja dla wspólnoty". tzn. serce każdego jej członka otwiera się na innych, nikogo nie wykluczając. Dwa wielkie niebezpieczeństwa przy budowaniu wspólnoty to przyjaciele i wrogowie. Przyjaźń źle pojęta prowadzi do zamknięcia drogi do innych ludzi, zamyka na ich potrzeby. Niektóre przyjaźnie przekształcają się pod wpływem czasu w uzależnienie emocjonalne, będące formą zniewolenia. Jeżeli pozwolimy, by kierowały nami emocje, bardzo szybko we wspólnocie powstaną klany, nie będzie to już wspólnota, lecz grupki osób zamknięte w siebie i zablokowane wobec innych. Zbyt wiele osób przychodzi do wspólnot po to, by coś znaleźć, wejść w dynamiczną grupę lub prowadzić życie zgodne $\mathrm{z}$ jakimś ideałem. Szybko spotyka ich zawód, jeśli wchodząc we wspólnotę nie wiedzą, że czeka tam na nich tajemnica przebaczenia (115).

Młodzież nie ma poczucia wspólnoty, jej religijność jest raczej indywidualistyczna. Podobnie kształtuje się również jest stosunek do wspólnot religijnych i ich oficjalnych przedstawicieli (116). 
Relacje osobowe między ludźmi, a Bogiem są właściwym środowiskiem człowieka. Inaczej mówiąc, wspólnota, w sensie faktu koniecznych dla człowieka relacji osobowych jest warunkiem tworzenia się wymiany wiedzy, mądrości, prawdy, piękna, bez których człowiek nie uzyska przypadłościowej pełni, przez którą w relacjach interpersonalnych rozumiemy interioryzację kultury, szczęście obecności i przyjaźni. Struktura osoby ludzkiej wymaga wspólnoty.

Wspólnota osób jest nam dana tak ze strony ludzi, jak i ze strony Boga. Rozpoczynamy swoją obecność wśród osób od daru istnienia, od daru miłości, dobra i prawdy. Pełne człowieczeństwo nie polega na zmianie naszego ontycznego statusu bytów przygodnych, lecz na uprawnieniu i obowiązku obdarowywania. Za to obdarowywanie jesteśmy najpierw odpowiedzialni. Jesteśmy odpowiedzialni wobec siebie, wspólnoty za to, czy obdarowujemy dobrem i czy przyjmujemy dar (117).

Można wyróżnić trzy stopnie uczestnictwa parafian w sprawach wspólnoty parafialnej:

- informowanie parafian o zarządzeniach, które ich bezpośrednio lub pośrednio dotyczą,

- informowanie o przyczynach podjętych decyzji, czyli ich uzasadnianie,

- uczestnictwo w przygotowaniu i podejmowaniu decyzji.

Niekiedy twierdzi się, że kwestia uczestnictwa parafian w zarządzaniu parafią została definitywnie załatwiona przez powołanie rad duszpasterskich i parafialnych. Wydaje się, że uczestnictwo parafian nie jest równoznaczne z instytucją rad parafialnych, i nawet najlepiej działająca rada nie oznacza jeszcze aktywności świadomego i czynnego uczestnictwa ogółu parafian. Jedną $\mathrm{z}$ form aktywizowania parafian jest przecież popieranie i pobudzanie inicjatywy małych grup (118).

Odkrycie wspólnotowego wymiaru Kościoła jest możliwe głównie przez Tradycję. Jakie warunki decydują o przynależności? Pierwszym z nich jest troska o doskonalenie wrażliwości sumienia. Ewangeliczna wspólnota jest otwarta, a człowiek odbiera Boże słowo przez sumienie. Drugim elementem wspólnototwórczym jest codzienne spotkanie się $\mathrm{z}$ ludźmi żyjącymi Ewangelią. Wrażliwość sumienia jest doskonalona przez spotkanie z ludźmi wartościowymi, niszczymy natomiast kontakt z człowiekiem żyjącym w świecie grzechu. Trzeci element to potrzeba maksymalizmu etycznego. Ewangeliczną wspólnotę mogą stanowić ludzie, którzy wciąż chcą czegoś więcej, którzy decydują się na rozwój. Ważnym elementem przy tworzeniu wspólnoty jest dziękczynienie. Wdzięczność ma dwa etapy. W pierwszym człowiek widzi dar, tak jak dziecko, w drugim etapie, widzi miłość i dobroć tego, który mu ten dar sprawił. Pragnie mu podziękować. Następnym elementem wspólnototwórczym jest uczciwość pracy. Ewangeliczną wspólnotę może tworzyć tylko człowiek uczciwy. We wspólnocie nie ma miejsca dla leniwych. Kolejnym etapem jest szacunek dla tego co święte (sacrum). Ostatnim elementem jest eschatologiczna zasada: spodziewam się najgorszego, a mam nadzieję na najlepsze. Zasada ta ukazuje perspektywę pokoju (119).

\section{2. 5. Konwersja}

Termin konwersja używany jest przede wszystkim w dziedzinie religijnej. Występuje on także w lingwistyce, prawie, chemii i elektronice. Wszystkie te dziedziny łączy pojęcie konwersji (łac. zgięcie, zmiana, skręt, przewrót). Termin ten oznaczał też od ok. 1190 roku zwrócenie się do Boga (conversionis ad Deum), a zatem miał sens głębszej przemiany duchowej. "Słownik Języka Polskiego" podaje pod terminem konwersja, jako jego religijny sens: zmiana wyznania $w$ obrębie wyznań chrześcijańskich, zwłaszcza przejście na katolicyzm. W języku polskim istnieje także termin nawrócenie, czyli nakłonienie kogoś do 
przyjęcia, ewentualnie przyjęcie jakiejś religii, wyznania (niekoniecznie chrześcijańskiego). W konotacji zarówno konwersji, jak i nawrócenia w języku polskim brak jest specyficznej treści "metanoia" głębokiej przemiany wewnętrznej. W języku niemieckim konwersja to "die Bekehrung", które odpowiada znaczeniowo łacińskiemu "conversio" i greckiej "metanoia", jako duchowe rozpoznanie prawdziwej wiary, wejście ze złej na dobrą drogę życiową, narodzenie się na nowo w wierze.

Motyw konwersji został wprowadzony do kultury europejskiej przez judaizm, a później przez chrześcijaństwo. Metanoia, jako grecki odpowiednik łacińskiego "conversio" zakłada świadome podejście od dotychczasowej postawy obojętności, która to zamiana zakłada także odejście od dotychczasowej formy religijności, przy świadomości dotychczasowego zła.

Konwersja jako kategoria socjologiczna jest procesem uwspólnotowienia, łączenie oddzielonych społeczności, przez podział pracy i własności, następnie artykułowanie ich działań przez nowe działania połączonej wspólnoty. Kolektywna konwersja jest w tym przypadku procesem społecznej transformacji i rozwoju grup o szczególnym charakterze. Chodzi tu o wspólnoty synergetyczne (synergetic communion) tj. wspólnoty współdziałające w podejmowaniu ryzykownych, nowych zadań, świadomie podejmujące się transformacji społeczeństwa i kultury. Do działania połączonego transformacyjnej wspólnoty dochodzi dzięki symbolicznej interakcji nawracającego i nawracanych pod kierownictwem konwertora. Kolektywny wymiar konwersji mają przede wszystkim jej rytuały, w których wespół występują uczestnicy wspólnoty. Rytuały ekspresyjne komunikują i sprawiają zamierzoną zmianę członków wspólnoty. Wspólnota konwersji, retoryka i rytuały konwersji wyczerpują w zasadzie analizę zjawiska jakim jest konwersja kolektywna. Jako proces zachodzący w czasie powinna ona być badana w związku z rozwojem i działaniem ruchów konwersji (120).

Konwersja religijna bywa analizowana $\mathrm{z}$ aspektu wielu dyscyplin wiedzy. Problem konwersji pojawia się w ramach badań socjologicznych, obejmując grupy i ich oddziaływanie na jednostkę w celu pozyskania jej pełnego udziału w grupie. Najczęściej te analizy mają miejsce w kontekście omawiania technik i wpływów wykorzystywanych przez nowe ruchy religijne, aby włączyć w swoje szeregi możliwie najwięcej zwolenników. Zagadnieniu temu są poświęcone m.in. prace T. Richardsona, J. Loflanda, R. Starka oraz E. Barker. Rozszerzenie rozumienia zjawiska konwersji ułatwia też $\mathrm{w}$ znacznej mierze perspektywa historyczna przyjęta dla jego analizy. Od początku wyodrębnienia psychologii jako samodzielnej dyscypliny badawczej, zjawisko konwersji religijnej było przedmiotem zainteresowania badaczy. Istnieją między nimi znaczne kontrowersje na temat tego, czy w przypadku włączania się ludzi do grup religijnych mamy rzeczywiście do czynienia $\mathrm{z}$ procesem konwersji, czy też manipulacją ich zdolności do dokonywania wyboru i oceny sytuacji. Zwolennicy tez o poddawaniu członków grup zabiegowi prania mózgu, bądź innym formom manipulacji świadomością, opierają swoje twierdzenia na zdroworozsądkowym przekonaniu, że nie jest możliwe w inny sposób wyjaśnienie zgody ludzi wywodzących się często z zamożnych rodzin, na życie w gorszych warunkach materialnych i podleganie taniej eksploatacji jako siła robocza. Natomiast zwolennicy poglądu o dobrowolnym charakterze tych konwersji akcentują raczej splot przyczyn sytuacyjnych (znalezienie się w obcym miejscu w czasie wakacji, luźne kontakty $\mathrm{z}$ domem rodzinnym) oraz przyczyn psychologicznych (brak celu i sensu życia, poczucie zagubienia i znudzenia prowadzonym życiem), jako stymulujących w sposób istotny włączanie się do nowych grup religijnych. Teza o praniu mózgu, lub innych sposobach manipulowania świadomością członków grup jest formułowana najczęściej w oparciu o wypowiedzi rodziców, których dzieci nagle, tj. bez podania przyczyn (widocznych i zrozumiałych) przyłączyły się do takich grup, porzucając dom rodzinny, czy szkołę. 
Zjawisko konwersji poddaje się również analizie $\mathrm{z}$ aspektu praw psychologii społecznej, dotyczących kształtowania i zmian postaw oraz przekonań pod wpływem kontaktów z innymi ludźmi, określanego mianem komunikowania społecznego.

G. Scobie dzieli konwersję na:

- mimowolną, przebiegającą pod wpływem procesu uczenia się społecznego będącą częścią całokształtu procesu socjalizacji jednostki, - stopniową, doprowadzającą poprzez szereg kolejnych zmian w świadomości jednostki do całkowitej zmiany jej poglądów,

- gwałtowną (rapid), polegającą na natychmiastowym przyjęciu nowych poglądów religijnych.

Przy pierwszym rodzaju konwersji mamy do czynienia z osobami, dla których religia jest częścią identyczności społecznej, ale nie odnosi się do głębszych warstw jej przekonań. Drugi rodzaj konwersji sprawia, że osoby przyjmują religię na drodze akceptacji przede wszystkim intelektualnej, jako odpowiedź na podstawowe pytania stawiane przez życie. Trzeci rodzaj konwersji występujący u osób ze skłonnościami histerycznymi, podatnymi na sugestię, ma charakter przede wszystkim emocjonalny, choć również poznawczo wartościujący, jako odkrycie, na zasadzie wglądu, nowego sensu życia.

Inne rozróżnienie proponuje $\mathrm{R}$. Travisano, wyodrębniając konwersję i alternację. Konwersję uważa on za zmianę identyczności wywołaną i związaną z całkowitą negacją identyczności poprzedniej. Alternacja, to pozostawanie $w$ ramach identyczności i rozszerzenie jej o nowe elementy. Konwersja właściwa pojawia się znacznie rzadziej niż alternacja.

Innym podziałem spotykanym $\mathrm{w}$ literaturze przedmiotu, jest podział $\mathrm{z}$ uwagi na sfery życia, które podlegają konwersji.

R. Thouless rozróżnia konwersję polegającą na zmianie komponentu przekonaniowego w postawie religijnej, konwersję moralną, dającą zmiany motywacji zachowań dotyczących sfery moralności, wreszcie konwersję społeczną, polegającą na zmianach $\mathrm{w}$ działaniu podejmowanym wobec środowiska społecznego. Zazwyczaj dochodzi do jednoczesnej zmiany we wszystkich określonych sferach, z tym jednak, że jedna $\mathrm{z}$ nich pełni rolę katalizatora rozpoczynającego proces przemiany jednostki. Zestawienie prac biograficznych $\mathrm{z}$ ostatnich lat (L. Rambo), wykazuje że badania psychologiczne konwersji stanowią mniejszość w stosunku do badań socjologicznych tego zjawiska. Świadczy to o coraz wyraźniejszym traktowaniu konwersji w kategoriach społecznych, i co za tym idzie badanego w kontekście socjologii religii. Nawrócenie religijne, konwersja, szczególnie ta występująca w postaci stopniowej może wywierać pozytywny wpływ na przeżywające ją osoby (121).

Konwersja religijna, jak każde inne definitywne zerwanie $\mathrm{z}$ dotychczas uznawanym systemem doktrynalnym i wybór nowej formuły aksjologicznej powoduje zmiany osobowościowe i wywołuje określone skutki społeczne. Pierwotny wybór wyznania dokonuje się bez angażującego udziału zainteresowanego, poprzez rodzinną socjalizację. Wyniki badań socjologicznych dowodzą względnej trwałości pokoleniowej transmisji przekonań. Konwersja w kierunku nowych wspólnot kultowych, powstających współcześnie jako jedna z możliwych form społecznej reakcji na wyzwania czasu, budzi szczególne zainteresowanie i domaga się uwiarygodniających wyjaśnień.

Konwersja jako zmiana wyznania nie oznacza utraty wiary, przeciwnie jest w niej umocnieniem, mimo wyboru innej wykładni doktrynalnej. Dowodzi odnalezienia w nowej religii bardziej adekwatnych i subiektywnie zadowalających form zaspokajania potrzeb, nie tylko religijnych, ale i społecznych (wspólnotowych). Nowe ruchy religijne spełniają wobec swych wyznawców określone funkcje społeczne. Wielość ruchów i ich różnorodna forma 
wyrazu daje szansę wyboru wspólnoty, nie tylko ze względu na jej walory duchowe, ale również i rodzaj ziemskiej aktywności.

Małe grupy kultowe zapewniają większą duchową koncentrację, dają uczucie ciepła i miłości, na których brak w rodzinach naturalnych respondenci często się uskarżali. Dla wielu uczestnictwo w nowych religiach jest wyzwoleniem od uzależnienia alkoholowego, ucieczką od samotności do wspólnoty przyjaciół, jest odejściem od apatycznego stanu beznadziejności, do nadziei w wierze. Możliwość bezpośredniego kontaktu z osobą charyzmatyczną, której posłannictwo i proroctwa potęgują uczucie wspólnotowego zespolenia i utwierdzają $\mathrm{W}$ słuszności wyboru drogi życiowej (122).

Nawrócenie (konwersja) polega na tym, że wchodzi się na drogę duchową, w której uprzednio ma się udział, następuje przemiana ze starego człowieka w nowego. To przejście, które znajduje swój wyraz zwłaszcza w sakramencie chrztu, musi mieć wpływ na przemianę całego życia danego człowieka i prowadzić do odnowy ludzkich wspólnot i instytucji (123).

\section{2. 6. Ruchy religijne jako wypełnienie luki między mikrostrukturami i makrostrukturami}

Fenomenem w panoramie religijności polskiej są, powstające od lat siedemdziesiątych i wcześniej, nowe ruchy i wspólnoty religijne. Obok tradycyjnych zespołów kościelnych, istniejących przy parafiach, powstają nowe $w$ ramach aktywności liturgicznej, katechetycznej, formacyjnej, studyjnej, wspólnotowo - osobowej, świadczenia sobie wzajemnej pomocy itp. Mają one na celu aktywny udział w życiu wspólnoty Kościoła. Przypominają one grupy etosowe lub alternatywne, działające w społeczeństwie. Współdziałają one na zasadzie partnerstwa w posłannictwie Kościoła, pogłębiają religijne zaangażowanie laikatu, są bardziej radykalne i bezkompromisowe niż ogół wierzących. We wspólnotach religijnych człowiek może uwydatnić i rozwinąć swoją indywidualność, zaznaczyć siebie jako jednostkę odrębną. Sens indywidualności ginie w masie (także kościelnej). We wspólnocie religijnej człowiek traktuje religię nie tylko według kryterium korzyści, czy psychicznego komfortu, ale przede wszystkim jako mobilizujące i poważne zjawisko, zajmujące ważne miejsce w systemie uznawanych wartości, jako istotny element stylu życia. Wielkie wspólnoty Kościoła nie mogą ze względu na swoją wielkość, strukturę i pełnione funkcje zapewnić wierzącym przestrzeni życiowej na miarę potrzeb i stworzyć warunki do subiektywnego i osobistego udziału. Od połowy lat siedemdziesiątych powstają i rozwijają się nowe wspólnoty religijne. Można je podzielić na ewangelizacyjno - modlitewne (Ruch "Światło - Życie”, Charyzmatyczna Odnowa w Duchu św. , Neokatechumenat, Ruch "Wspólnota i Wyzwolenie", Fokolarini). Innym typem są wspólnoty społeczno - religijne (Gaudium Vitae, Pro Familia ,"Wiara i Światło", Maitri, Pax Romana, Przymierze Rodzin), duszpasterskie (Rodzina Rodzin, Wspólnota Życia Chrześcijańskiego, Totus Tuus itp).

Szczególnie młodzież przez małe wspólnoty odnajduje swoją świadomość apostolską, stając się grupą współuczestniczącą w Kościele. Wspólnoty i ruchy religijne mające częściowo charyzmatyczny charakter i działające częściowo poza ramami instytucjonalnymi Kościoła, skupiają ludzi o tych samych zainteresowaniach, pragnieniach, chcących dzielić się wspólnymi problemami. Te małe grupy pomagają ludziom rozwiązywać problemy życiowe. Stanowią swoiste antidotum na anonimowość współczesnego życia, kryzysy społeczne i urzeczowienie stosunków międzyludzkich.

Przeżycia wspólnotowe są bardziej ważne niż refleksja intelektualna, chociaż i ta ostatnia nie jest na ogół lekceważona. Między jednostką, a wspólnotą istnieje odpowiedniość i stosunek wzajemnego warunkowania. Jednostka potrzebuje wspólnoty do usensowienia swojego życia, wspólnota potrzebuje zaangażowanych jednostek gwarantujących sens jej 
istnienia. Masa dostrzega tylko użyteczność jednostek, natomiast nie widzi ich wartości osobowej, godności, niepowtarzalności, wyjątkowości. Decyzja na życie we wspólnocie religijnej powinna być dojrzałym, świadomym wyborem. Poszukiwanie bezpieczeństwa w małych grupach może jednak prowadzić do chorobliwej zależności od wspólnoty i poważnej utraty własnej samodzielności.

Przymus grupy stanie się wtedy formą terroryzmu. Związek $\mathrm{z}$ grupą stanie się ekskluzywny, wszyscy ludzie poza wspólnotą zostaną potraktowani jako wrogowie. We wspólnotach religijnych działalność skupia się na problemach życia religijnego, przeżywaniu podstawowych prawd wiary, studiowaniu Pisma św., aktywnej miłości bliźniego, dawanie świadectwa chrześcijańskiego, doskonalenie siebie. Wspólnoty podstawowe są częścią integralną Kościoła, nawet jeśli wśród niektórych członków istnieje tendencja uniezależniania się od hierarchii kościelnej. Przeżywanie wiary $w$ małych grupach daje możliwości identyfikacji czynnej. Wiara staje się czymś co przeżywa się wspólnotowo i osobowo zarazem, co skłania do podejmowania cennych inicjatyw ewangelizacyjnych. Szersza prezentacja ruchów $\mathrm{w}$ aspekcie socjologicznym byłaby istotna dla całokształtu charakterystyki i obrazu życia religijnego współczesnej Polski (124).

N. Mouzelis stwierdza, że korzystnie jest rozróżnić więcej niż trzy poziomy analizy organizacji (jednostka, grupa organizacja). Na każdym z tych trzech poziomów pojawiają się wciąż emergentne zjawiska nie dające się zredukować do zjawisk poziomów niższych. Dychotomia (formalny - nieformalny) przestaje być stopniowo punktem zainteresowania teorii organizacji, użyteczność tej teorii dychotomii staje się problematyczna (125).

E. A. Shills stwierdził, że ludzie nie podlegają bezpośredniemu wpływowi centralnych wartości społeczeństwa, czy też centralnych jego norm. Elementem pośredniczącym (mezostrukturą) między społeczeństwem, a jednostką są grupy pierwotne (m. in. wspólnoty). Jak już poprzednio stwierdzono, podział na makro i mikrostruktury ze względu na dzielącą je przestrzeń nie jest w pełni adekwatny. Do mezostruktur społecznych zaliczamy zbiorowości terytorialne, zrzeszenia i ruchy oraz procesy społeczne generujące nowe obszary zachowań w czasoprzestrzennym układzie mezostrukturalnym (126).

Wewnętrzna spójność i silniejsze związki strukturalno - funkcjonalne mezospołeczności warunkują też większe i skuteczniejsze przekazywanie norm i wartości w grupie. Totalne zablokowanie ujarzmienie i podporządkowanie społeczności, odebranie jej możliwości wpływu na całokształt procesów zewnętrznych powoduje silny kierunek "ad intra", tendencję do zamykania się we własnym środowisku skupienie się na własnych problemach i oderwanie się od zadań i celów makrosystemu (Kościoła powszechnego) (127).

Makrospołeczność jest uzależniona od mikro i mezospołeczności, potrzebuje ich do wyjścia z kryzysu. Odnowa Kościoła i świata prowadzona przez ruchy i grupy wspólnotowe odsuwa powoli stare formy, które zużyły się w negacji. Nowe prądy jeszcze nie mają pełnego głosu w toczącej się debacie wielkich idei, wzrastając w milczeniu (128).

Ruchy społeczne jak pisze $H$. Blumer, są zbiorowymi przedsięwzięciami zmierzającymi ku ustanowieniu nowego porządku rzeczy. Biorą one swój początek $\mathrm{z}$ niepokoju. Czerpią swoją siłę z niezadowolenia aktualną formą życia oraz nadziei na lepszy nowy sposób życia. Ruchy społeczne są wyższą formą działań zbiorowych, polegającą na przekształcaniu nie skoordynowanych, żywiołowych zachowań w uporządkowane przedsięwzięcia. B. Misztal, powołując się na T. Abella pisze, że ruch społeczny postrzegany był jako forma spluralizowanego zachowania, pojawiającego się w ramach określonej jednostki terytorialnej (społeczności). Jego cechą jest zbiorowy wysiłek mający na celu przyciągnięcie poparcia dla jakiejś innowacyjnej idei. Ruch jest zawsze skierowany przeciwko czemuś (podmiot ruchu, punkt sporny z resztą społeczeństwa), w równej mierze 
co w kierunku czegoś (ideologie ruchu). W tym sensie każdy ruch powoduje uwikłanie w konflikt, zaś ulokowanie $\mathrm{w}$ ramach określonej społeczności nadaje mu aspekt polityczny. A. Turaine, stwierdza, że ruchy społeczne są konfliktowymi działaniami aktorów klas społecznych walczących o kontrolę systemu działan historycznych. Podstawowym wyróżnikiem ruchów społecznych jest dla autora ich historyczność. Pojęcie to definiuje następująco: "Działanie skierowane na praktyki społeczne i $\mathrm{v}$ kulturalne za pomocą kombinacji trzech składników - formy wiedzy tworzącej obraz społeczeństwa i natury, akumulacji umożliwiającej zawłaszczenie pozostającej do dyspozycji części produktu oraz modelu kulturalnego który ujmuje i interpretuje zdolność oddziaływania społeczeństwa na siebie. Historyczność staje się tutaj kontrolą nad społecznym tworzeniem rzeczywistości. Każdy ruch społeczny charakteryzują trzy cechy: samoidentyfikacja aktora (ruch nie zaistnieje bez samookreślania się), zasada opozycji (musi istnieć przeciwnik), zasada całości (ruch elementem rzeczywistości historycznej). Masowość działań zbiorowych nie musi być wcale cechą konstytutywną ruchu społecznego. Przeciwnie, cechą charakterystyczną współczesnych społeczeństw jest wielość ruchów społecznych. Wynika z tego duże zróżnicowanie współczesnego społeczeństwa, jego wielopodmiotowość, rozmaitość interesów oraz aspiracji i potrzeb (129).

Powstawanie nowych ruchów (zwłaszcza religijnych) jest tym rodzajem przemian współczesnej religijności, które dla psychologii religii stanowią swoisty eksperyment naturalny z zakresu dynamizmów religijności grupowej. Pojęcie "nowe ruchy religijne" obejmuje mozaikę około ośmiu tysięcy grup religijnych powstałych w ciągu ostatnich trzydziestu lat w USA, Europie Zachodniej i Polsce. Liczba członków tych grup waha się w granicach 10 - $25 \mathrm{mln}$. Charakter tych grup jest ogromnie zróżnicowany, wyodrębnia się wśród nich grupy nastawione opozycyjnie do istniejącego porządku społecznego, grupy adaptujące się do istniejącej struktury społecznej oraz działające na marginesie społeczeństwa. Analizy powstawania tych grup doprowadziły do opracowania trzech podstawowych modeli przebiegu tego procesu: psychopatologicznego, innowacji kulturowej i ewolucji subkulturowej (130).

Najstarszy jest model psychopatologiczny (kult jest formą nowej reakcji na kryzysy indywidualne $\mathrm{i}$ społeczne). Grupy kultowe są tworzone przez jednostki cierpiące na zaburzenia psychiczne. Osoby te przeżywają wizje posłannicze w trakcie epizodów psychotycznych. W ich trakcie jednostka konstruuje nowy zespół kompensatorów, choroba psychiczna jednostki powoduje zaangażowanie w nową wizję. Przez bardzo realistyczne halucynacje, po przebytym po przebytym epizodzie psychotycznym jednostka odnosi sukces w tworzeniu grupy kultowej wokół własnej wizji. Jeśli w społeczeństwie jest wiele osób cierpiących z powodu podobnych problemów nowe grupy kultowe zyskują na popularności. Podobnie rzecz się ma w przypadku kryzysów społecznych, gdy więcej osób cierpi na nierozwiązywalne problemy. Jeśli kult odniesie sukces zyskując wielu zwolenników, jego założyciel może zostać wyleczony co najmniej z części swych zaburzeń, ponieważ stworzone przez niego kompensatory, czyli wypracowane formy rozwiązywania problemów potwierdziły swą skuteczność w rozwiązywaniu problemów innych osób. Kult staje się rodzajem przedsięwzięcia handlowego. Grupy kultowe zajmują się "sprzedażą" coraz to nowych kompensatorów. Grupy te są podobne do siebie, ponieważ elementy składowe kompensatorów, którymi operują nawzajem się przenikają. Idee całkowicie nowych kompensatorów są rozwijane bardzo ostrożnie i włączane tylko w przypadku pozytywnej odpowiedzi rynku na przedłożoną przez założyciela grupy propozycję. Z uwagi na rodzaj kompensatorów wyróżniamy trzy rodzaje grup tego typu: kulty publiczności, kulty grup o 
specyficznych potrzebach i ruchy kultowe. Oba poprzednie modele określały rolę pojedynczego człowieka tworzącego kult.

Model ewolucji subkulturowej podkreśla rolę procesów interakcji grupowej. Grupy kultowe są rodzajem nowej struktury społecznej, najłatwiej powstają w społeczeństwach zaangażowanych religijnie, są skutkiem ubocznym nie przynoszącym sukcesów kolektywnych dążeń do uzyskania rzadkich, lub nie istniejących nagród. Ewolucja zaczyna się, gdy grupa osób angażuje się w otrzymanie pewnych nagród. Współpracując nad otrzymaniem nagród jednostki zaczynają wyłaniać między sobą inne nagrody, uświadamiając sobie porażkę w osiąganiu założonych celów. Osoby stopniowo wymieniają kompensatory, które mają zastąpić te cele. W miarę wymiany nagród i kompensatorów grupa staje się coraz bardziej zamknięta. Pozbawiona do pewnego stopnia kontroli grupa społeczna rozwija się i konsoliduje nową kulturę stymulowaną przez potrzebę wymiany nagród i kompensatorów między jej członkami. Końcowym punktem pomyślnie zakończonej ewolucji kulturowej jest nowa grupa religijna, która musi rozwiązać problem środków egzystencji oraz nowych członków z otoczenia. Szybkość przemian jakim podlegają nowe ruchy religijne pozwala $\mathrm{W}$ ciągu jednego pokolenia przyjrzeć się procesom prowadzącym do powstawania, rozkwitu, upadku, a nawet całkowitego zaniku określonych sposobów interpretacji i kształtowania świata (131).

Członkostwo w ruchach na poziomie zaangażowania jednostki wynika z uczestnictwa we wspólnocie. Najstarsze rozumienie przyjmuje zaliczanie do wspólnoty tych wszystkich, którzy biorą udział w spotkaniach tzw. małych grup "dzielenia się". Są one podstawowymi komórkami każdej wspólnoty. Każdy z animatorów (prowadzących grupę) przeprowadza cotygodniowe spotkanie modlitewno - biblijno - opisowe. Opis dotyczy własnego wzrostu duchowego (132).

Kościół stwierdza wyraźnie, iż jest uzależniony w pierwszym rzędzie od świadectwa dawanego przez chrześcijan w łonie wspólnoty światowej. To oni promieniują przez swój sposób życia. Parafie zdające się być głównym ośrodkiem życia religijnego zdają się zupełnie zamierać. Należałoby zwrócić baczniejszą uwagę na miejsce oddziaływania ewangelizacyjnego przez grupy i nowe ruchy duchowe. Jest przecież faktem, że to właśnie tam odnotowuje się w naszych czasach największe liczby nawróconych (konwersji). Struktury tradycyjne, wydają się być sprowadzone do sektora podtrzymywania i obsługi wiernych będących jeszcze w Kościele (133).

Człowiek z natury chce tworzyć, stąd konieczne jest czasami odrzucanie, bo nawet odrzucając (burząc) człowiek przygotowuje warunki dla rzeczy nowych. Większe szanse mają też ludzie, którzy proponują coś nowego, to będzie zawsze atrakcyjniejsze. Jeśli patrzy się na historię świata idei, różnych wspólnot, to widzi się, że radykalne stawianie sprawy przyciąga zwolenników (134). Z tym wiąże się też powodzenie włoskiego ruchu "Communione e Liberazione". Próbuje on odpowiedzieć na pytania dotyczące przemian we współczesnej kulturze, także politycznej, odnosząc przemiany do Ewangelii i generując wiele sukcesów.

Mając na uwadze wielki boom ruchów rodzinnych w Polsce zauważyć należy, że przyjęcia człowieka powinna oczekiwać nie jednostka lecz osoba, a więc wspólnota osób. Osoby oczekiwać możemy tylko wspólnotowo. Oczekiwanie stanowi moment samej "arche" bycia osobą. W oczekiwaniu właściwym dla osobowego bycia człowieka urzeczywistniają się przyjaźnie, małżeństwa i rodziny. Tego rodzaju refleksje nie przekonują tych, którzy myślą o człowieku jako funkcjonującym w określonym systemie. Dla tych natomiast, którzy długo współżyją z osobami, pozostając we wspólnocie życia, zasady osobowego istnienia są oczywistością. Po co więc mówić im o oczywistościach ? Po to, by byli jeszcze bardziej 
świadomi potrzeby gościnności, oczekiwania na nadchodzących. Osoby tak oczekujące innych pomagają innym dojrzewać do uszanowania osoby ludzkiej (135).

Zachowując należyty stosunek do władz kościelnych świeccy mają prawo zakładać stowarzyszenia, kierować nimi i wstępować do już istniejących. Jeśli zrzeszenie wiernych zawsze było zjawiskiem w jakiś sposób obecnym w historii Kościoła, to niezwykłe ożywienie $\mathrm{w}$ tej dziedzinie nastąpiło $\mathrm{w}$ czasach najnowszych, kiedy powstały i rozszerzyły się nowe rodzaje zrzeszeń: stowarzyszenia, grupy wspólnoty, ruchy. Można mówić o epoce zrzeszeń katolików świeckich. Są one nazwane podmiotami społecznymi mogącymi skutecznie wpływać na zmiany kulturowe w pluralistycznym społeczeństwie i stanowić w zsekularyzowanym świecie wyjątkowo cenną pomoc dla wielu ludzi w prowadzeniu życia chrześcijańskiego zgodnie z wymogami Ewangelii i w zaangażowaniu misyjno - apostolskim. W konsekwencji postawy obronnej, troska Kościoła o życie kultyczne nie znalazła pogłębienia w budowaniu wspólnoty. Kościół sprowadza się w swym zewnętrznym kształcie do sprawowania władzy duszpasterskiej, szafowania sakramentów, często z pomocą własnej biurokracji, przy małej otwartości na różnorodność charyzmatów, nieufności wobec grup i wspólnot kościelnych, które gromadzą zwłaszcza na poziomie parafii wiele osób. Przed stawaniem się parafii tylko terytorium, lub budynkiem ostrzega adhortacja "Christifideles Laici" (136). Świadectwem gorszącym jest występowanie nieuzasadnionych przywilejów działania na podstawie zlecenia ze strony proboszcza, zamiast otwartej, dostępnej każdemu wiernemu służby we wspólnocie. Niewystarczalność obecności świeckich w życiu Kościoła w Polsce objawia się tym, że istnieją jak dotąd stosunkowo nieliczne rady duszpasterskie, a działalność wielu istniejących jest raczej pozorna, niż istotna. Nie istnieją wszędzie zalecone przez prawo kanoniczne, ekonomiczne rady parafialne. Świeccy szukając możliwości realizacji przykazania miłości bliźniego starają się dzielić swoim doświadczeniem. Dzieje się to $\mathrm{w}$ rozmaitych kontaktach $\mathrm{z}$ ludźmi, ale naturalnym do tego miejscem są wspólnoty, stowarzyszenia $i$ ruchy. Stanowią one wyjątkowo cenną pomoc w prowadzeniu chrześcijańskiego życia zgodnie z Ewangelią. Nieformalne grupy młodzieżowe, działające jako ruchy oddolne $\mathrm{z}$ wypracowanym własnym programem, stwarzają możliwości doświadczania Kościoła jako wspólnoty, oraz zapewniają większe możliwości formacyjne. Jednostka $\mathrm{w}$ grupie przestaje być anonimowa, stając się podmiotem, występującym $\mathrm{z}$ inicjatywą działania oraz odpowiedzialnością. Pozwala to młodemu człowiekowi podejmować własne, przemyślane decyzje, w oparciu o pogłębioną świadomość religijną, prowadząc do rozwoju wiary i życia inspirowanego wiarą oraz czynnego apostolstwa. Znamienną cechą odnowy biblijnej jest szczególne zainteresowanie Biblią wśród małych wspólnot i grup kościelnych, związanych z odnową Kościoła. Powstaje ich coraz więcej, tak iż muszą wejść trwale w panoramę duszpasterstwa parafialnego. W ruchu oazowym np. cały system formacyjny i wychowawczy jest oparty na Piśmie św. Małe wspólnoty Ruchu, zarówno podczas rekolekcji, jak i podczas formacji rocznej wykorzystują różne metody spotykania się ze Słowem Bożym. Obejmują one swym zasięgiem wielotysięczne rzesze oazowiczów - Ruch odgrywa niepodważalną rolę w odnowie biblijnej Kościoła w Polsce. Duszpasterze powinni rozszerzać i uaktywniać wszelkie kręgi biblijne, również poza ruchami odnowy, uwzględniając ich specyficzne problemy i formy aktualizacji, do orędzia biblijnego. W tym celu zarówno w aspekcie egzegezy historycznej jak i teologii duchowości należy zadbać o przygotowanie kompetentnych animatorów (136).

Nowe ruchy religijne występują z własnym systemem doktrynalnym, który spaja mniej lub bardziej zorganizowaną wspólnotę wiernych izolującą się lub aktywnie przeciwstawiającą otaczającemu światu. Nowa wspólnota jest na ogół organizowana przez osobowość charyzmatyczną, która staje się jej przywódcą, po czym władza takiego 
przywódcy religijnego, która pozwala mu przewidywać przyszłość, wskazywać nową drogę ma charakter autorytarny. W rozwoju nowych ruchów religijnych ujawniają się dwie przeciwstawne tendencje: jedne wspólnoty stabilizują się, wykształcają wewnętrzną organizację nierzadko hierarchiczną, kanonizują doktrynę i kult, dążą wyzbywając się pierwotnego ducha protestu do pozyskania społecznej i politycznej akceptacji, przekształcając się w denominacje i Kościoły, inne nie osiągają organizacyjnej spójności, powstają i rozpadają się, a jeśli nawet zdołają wytworzyć względnie stałe struktury oddzielają się od niej nowe sekty i grupy. Nowe ruchy religijne, takie o charakterze etnicznym są tworzone przez osobowości charyzmatyczne, reformatorów religijnych, są też oczekiwaniem wyzwolenia duchowego i na ogół także społecznego. Z aspektu roli społecznej, nowe ruchy religijne można podzielić na te, które religię traktują jako przestrzeń wolności i te, które protest redukują do wymiaru życia duchowego jednostki, propagując ucieczkę od świata. Izolują one wspólnotę od rzeczywistości społecznej, w konsekwencji godzą się z istniejącą rzeczywistością, za jedyną rzecz naprawy świata uznają doskonalenie jednostki poprzez jej oświecenie, ćwiczenia duchowe, formy życia ascetycznego, udział w przeżyciach mistycznych, wywoływanych także uczestnictwem w zbiorowym kulcie wspólnoty. Uczestnictwo w nowych ruchach w społeczeństwach uprzemysłowionych warunkowane jest pustką między jednostką i społeczeństwem. Stanowią one swego rodzaju strukturę pośrednią (mezostrukturę). Pustkę pogłębia kryzys tradycyjnej rodziny i zbiurokratyzowanie historycznych kościołów obywatelskich. Jednostki społecznie upośledzone, sfrustrowane, wyobcowane, samotne, zwłaszcza ludzie młodzi, ale także starsi, pozbawieni rodziny, nieszczęśliwi z różnych powodów poszukują grupy identyfikacji i często znajdują ją $\mathrm{w}$ nowym ruchu religijnym. Uczestnictwo zwłaszcza w młodym pokoleniu, w ruchu religijnym jest warunkowane kryzysem zaufania do panującego systemu wartości obywatelskich, jak i religijnych. Kryzys zaufania do nauki wiąże się z poszukiwaniem nowej nauki, nowej wiedzy, co warunkuje udział w ruchach parareligijnych. Kryzys zaufania do tradycyjnych wartości religijnych wynikać może z indywidualizacji i subiektywizacji wartości religijnych, z poszukiwania nowych sposobów przeżywania wiary, pragnienia bardziej intensywnego przeżywania wiary we wspólnocie. Obserwacja ekspansji niektórych ruchów religijnych w społeczeństwach postindustrialnych ujawnia znaczenie nowoczesnych technik komunikacji społecznej, w warunkowaniu uczestnictwa w tych ruchach (137).

Ruchy religijne są zbiorowościami o dość zwartej strukturze. Wymagają one od swoich uczestników większego zaangażowania i wyraźnego określenia swojej tożsamości religijnej, co oczywiście wiąże się $\mathrm{z}$ pewną wyłącznością $\mathrm{w}$ tej dziedzinie. Tymczasem ruchy parareligijne (zorientowane zazwyczaj na wartości doczesne), nie wymagają monoreligijności. Stąd też ruchy parareligijne, zwłaszcza na Zachodzie są bardziej v rozpowszechnione niż ruchy religijne. W Polsce $\mathrm{w}$ chwili obecnej istnieje jeszcze przewaga ruchów religijnych, jednak istnieje wiele przesłanek wskazujących na zmianę proporcji na wzór zachodnioeuropejski (138).

W przypadku uczestników katolickich ruchów religijnych mamy do czynienia z tzw. zjawiskiem rekonwersji, a nie $\mathrm{z}$ procesem konwersji do tradycji kulturowo odmiennej. Socjalizacja religijna jest $\mathrm{w}$ znacznym stopniu kontynuacją, niż przełomem, nie ma w niej momentu dezintegracji (występującego w konwersji). Cele życiowe uczestników ruchów odnowy są wyraźniej określone i częściej lokowane w rzeczywistości, którą można by nazwać uporządkowaną ze na społeczne i kulturowe wzory (139).

Oficjalne enuncjacje Kościoła katolickiego na temat nowych ruchów religijnych pozwalają na pewne uogólnienie. Po pierwsze ruchy o proweniencji chrześcijańskiej, jak i neoorientalnej a także ruchy synkretyczne są poważnym zagrożeniem dla realizowania przez 
Kościół programu reewangelizacji świata. Alternatywne ruchy religijne, czerpiące inspirację z chrześcijaństwa, są traktowane jako sekty i wyraźnie zwalczane, natomiast pozostałe ruchy, zwłaszcza neoorientalne uważane są za groźną konkurencję. Dotyczy to zwłaszcza przypadków, gdy ich wyznawcy rekrutują się głównie z Kościoła katolickiego. Po drugie, trafna diagnoza opisująca determinanty ekspansji nowych ruchów religijnych jest $\mathrm{w}$ istocie autorefleksją Kościoła ujawniającą jego słabe strony w obecnej rzeczywistości społecznej (140).

Jeżeli stopień prawdopodobieństwa realizacji programu odnowy moralnej jest mały, to nie jest on równoznaczny z prawdopodobieństwem zerowym. Ważną rolę odgrywać będzie inicjująca i mała grupa, przyczyniająca się do ujawnienia pozytywnych postaw moralnych, także w makroskali społecznej (141).

Dynamika postaw apostolstwa świeckich będzie miarą dojrzałości Kościoła, jego walorów ogólnoludzkich. Nowa świadomość Ludu Bożego stworzy w przyszłości struktury władzy, i życia wspólnotowego w Kościele, struktury dialogu, kolegialności i efektywnego uczestnictwa. Status duszpasterstwa i laikatu nie jest wielkością niezmienną. Każdy jest odpowiedzialny za cały Kościół w swoich wymiarach, tym bardziej odpowiedzialny, im bardziej czuje się chrześcijaninem. Dlatego nawet wbrew praktycznym trudnościom świeccy dysponują wielkimi możliwościami twórczymi, nieraz większymi niż prezbiterzy. Pod tym względem trzeba się strzec tylko największego zła w Kościele - walki o władzę i osobiste doczesne znaczenie. Jeżeli przekształcenia świadomości chrześcijańskiej mają iść w kierunku opisanym przez socjologa włoskiego S. Burglassiego (koncepcja spontaniczna, oparta na miłości, interakcyjność kontaktów, personalizm, wspólnotowość w działaniu, religijne inspiracje pastoralne doświadczenie, otwartość w zawierzeniu, ekumenia, duchowa posługa, funkcja profetyczna), to zadania stojące przed Kościołem dnia dzisiejszego, zwłaszcza w Polsce są ogromne. Nie ma szans ich realizacji bez całościowej roli świeckich w parafii Kościele diecezjalnym i powszechnym (142).

Istnieją dwie cechy podstawowe charakteryzujące małe grupy religijne, które funkcjonują w parafii: wzajemna przyjaźń chrześcijańska oraz gotowość niesienia konkretnej pomocy Kościołowi w urzeczywistnianiu jego misji (143).

Istnieje pewne nieporozumienie w traktowaniu niektórych ruchów alternatywnych, jako religijne. Aby jakiś ruch mógł nazywać się religijnym musi spełniać co najmniej dwa z trzech warunków: musi udzielać ostatecznych odpowiedzi na pytania o sens istnienia, musi wierzyć $\mathrm{w}$ istnienie bytu nadprzyrodzonego (Boga), ponad światem dostrzegalnym przez zmysły, oraz musi zawierać ryty i obrzędy wyrażające cześć, przebłaganie, lub prośbę wobec tego Bytu. Współczesne alternatywne ruchy o zabarwieniu religijnym powstają w oparciu o następujące cechy: ekskluzywizm (tylko ci co należą do ruchu znają prawdę i mogą się zbawić), oddzielenie od świata (ruch organizuje czas wolny swym członkom), woluntaryzm (nacisk na wolę członka by postępował według zasad ruchu), ślepe podporządkowanie przywódcom (decyzje dowódców przychodzą od Boga i nie mogą być dyskutowane), fanatyzm (przekonanie o posiadaniu wyłącznej, absolutnej prawdy uniemożliwiającej dialog (144).

Jeśli misja Kościoła jest ważna dla całej ludzkości i świata, to każda wspólnota, która rości sobie pretensje do katolicyzmu i tkwi w nim powinna przeciwstawiać się sektom. Ruchy duchowne i sekty wykluczają się nawzajem. Z socjologicznego punktu widzenia istnieje pewne podobieństwo między tymi rodzajami wspólnot. To podobieństwo jest szansą dla duszpasterstwa. Ruchy odnowy czy zakony powodują, iż odwrócenie się od grupy nigdy nie jest stanowcze i całkowite, odstępuje się, aby ponownie przygotować się do włączenia. Jest to zjawisko odwrotne do zachodzącego w sektach (145). 
Niektóre grupy nieformalne stają się dla Kościoła niewygodne, gdyż podejmują krytykę i kontestują jego instytucjonalizm. By małe grupy nieformalne mogły być nazwane kościelnymi, by mogły być seminariami ewangelizacji i nadzieją Kościoła powszechnego, muszą spełniać określone warunki. Jak zaznacza Paweł VI w adhortacji "Evangelii Nuntiandi”, będą one spełniać je o ile:

- opierają się ciągłej pokusie systematycznej kontestacji i duchowi superkrtytycyzmu,

- mocno wkorzeniają się w Kościół miejscowy, broniąc się przed zaślepieniem w sobie,

- zachowują szczerą łączność z hierarchią,

- nie uważają nigdy, iż są jedynymi adresatami Ewangelii,

- codziennie wzrastają w poczuciu obowiązków i gorliwości religijnej, - wykazują poczucie wspólnoty (146).

Po to, aby między wszystkimi dziełami, akcjami apostolskimi istniała jedność i współpraca, konieczna jest pomoc specjalnych rad parafialnych, diecezjalnych i międzydiecezjalnych, narodowych i międzynarodowych. Instytucją nadrzędną stanowi tutaj Sekretariat "Consilium de Laicis" w Watykanie. Jego zadaniem jest, aby Kościół był miejscem spotkania wiernych $\mathrm{z}$ hierarchią, a także wymianą spostrzeżeń z różnych ruchów, wspólnot kościelnych, w których biorą udział ludzie świeccy (147).

Ciekawy model powstawania wspólnot istnieje we Francji. Wspólnoty działają przede wszystkim w parafiach. Charakteryzuje je spontaniczność i szczerość przeżywania wiary, co wiąże się z tym, iż grupy te liczą niewiele osób (zazwyczaj do 15). Jeżeli chętnych jest więcej wówczas tworzona jest nowa wspólnota podstawowa (148).

Ruch "wiara i światło" istniejący w wielu krajach świata jest dość niezwykłym zjawiskiem na tle innych ruchów kościelnych laikatu. Stowarzysza on bowiem głównie ludzi upośledzonych umysłowo, jak również ich rodziny, przyjaciół. Jego celem jest budowanie wspólnoty wokół tych, którzy zazwyczaj są odrzucani przez tzw. normalne społeczeństwo (149).

Konserwatyzm, głęboko wpisany w swą naturę, potrafi Kościół połączyć ze znajdowaniem nowych form działania, bardziej adekwatnych do potrzeb aktualnej epoki historycznej. "Ecclesia semper reformanda". Proces ten ma bardzo interesujący przebieg w okresie powojennym, choć czas ten dla Kościoła jest jednym z najcięższych w dziejach. Nastąpiło bowiem zderzenie tradycyjnego duszpasterstwa $\mathrm{z}$ masowymi prądami laicyzacyjnymi. Kontestacja Kościoła i jego misji w większości krajów świata przeniknęła do mas. Jednak w tym właśnie czasie pojawiły się oddalone ruchy odnowy religijnej, nacechowane spontanicznym szukaniem innych niż przyjęte w tradycyjnym duszpasterstwie form ekspresji religijnej i życia chrześcijańskiego (150).

Błędem jest tłumaczenie wzrostu religijności w ciągu ostatnich lat tylko wpływem czynników politycznych. Oprócz nich dużą rolę odegrały (zwłaszcza w Polsce) nowe ruchy religijne. Tymczasem Kościół prowadzi w zdecydowanej większości duszpasterstwo masowe, a nie specjalistyczne. Wspólnoty ruchów odnowy występują tylko w 35\% parafii. Papierkiem lakmusowym przemian polskiej religijności, powinny być postawy młodzieży. Rośnie przy tym ilość osób wierzących świadomie (z wyboru) (151).

Przed podsumowaniem jeszcze krótko o ruchach zwanych emancypacyjnymi. Należą do nich ruchy feministyczne, pacyfistyczne, ekologiczne. Jest jasne, że chrześcijanie powinni zabierać głos w sprawie zanieczyszczonego środowiska, podobnie jak Kościół przez papieża zabiera głos w sprawie pokoju na świecie. Jednak w tych ruchach chodzi o coś innego, o nową walkę klas, a tym samym o nową nienawiść (152). 
Podsumowując powyższe rozważania stwierdzić należy, iż wspólnota jest doskonałą grupą społeczną (typem idealnym) będącą także podmiotem połączonej woli naturalnej. Aby jednak mogła stać się źródłem jedności dla swoich członków, musi wyrosnąć z fazy kiedy jest tożsama $\mathrm{z}$ połączoną $\mathrm{w}$ niej i logiczną wolą większości. Wspólnota, którą można najpełniej ująć jako metafizyczny związek, który ma od natury daną własną wolę w odniesieniu do woli swoich członków, a wola jej członków okazuje się tylko modyfikacją i emanacją organicznej substancji ogółu. Wolą naturalną jest przy tym ogół tych wszystkich sił, które posiada w sobie człowiek, a dzięki którym potrafi budować jedność z innymi ludźmi (153).

Budowanie wspólnoty polega na oparciu o dziedzinę wartości i symboli religijnych, a więc takich, które odnoszą się do najgłębszej rzeczywistości ukrytej pod powierzchnią doświadczenia, rzeczywistości świętej, w którą zaangażowana jest ludzka egzystencja, w której znajdują rozwiązania jej antynomie (154).

Społeczne uczucie jedności "My" w przypadku wspólnoty opiera się wszakże nie na uczuciach jednostkowych lecz na sacrum, które jednostki czczą. Pierwotnie uczucia każdej jednostki kierują się nie ku "My", ku członkom wspólnoty, lecz ku sacrum. Jest to jednak sacrum doświadczane przez jednostki i wspólność tego doświadczenia oraz uczucia łączy je społecznie. W przypadku wspólnoty religijnej opiera się ona na kolektywnej koncepcji sacrum podzielanej przez wszystkie osoby tworzące daną wspólnotę (155).

Wszystko to nie oznacza, że nie rozwijają się nowe różnice we wspólnocie w oparciu o nowe kryteria. Takim podstawowym kryterium jest charyzmat. Podzielanie wspólnego doświadczenia przy realizacji charyzmatu niebywale jednoczy członków wspólnoty (156).

Spontanicznie utworzona wspólnota może być nazwana wspólnotą egzystencjalną. Jest ona zazwyczaj krótkotrwała, ponieważ jest poddana wszystkim właściwym formom życia społecznego, zwłaszcza strukturalizacji (artykulacji form tego życia). Wspólnota, chociaż w najmniejszym stopniu w porównaniu do „Gemeinschaft i Gesellschaft” - charakteryzuje się jakąś organizacją. Tutaj właśnie pojawia się społeczna kontrola, mobilizacja i organizacja zasobów dla realizacji chociażby jednego tylko celu utrzymania i rozwoju communitas w strukturalnym kontekście konwencjonalnego społeczeństwa. W rzeczywistości społecznej spotykamy zatem wspólnoty normatywne, gdzie stosunki „my” oparte są na pewnych normach (157).

Kościół w swoim dziejowym posłannictwie odegrał i odgrywa wielką rolę w procesie budowania wspólnot. Sam Kościół istnieje przecież jako koinonia (przestrzeń komunii). Jest to komunia widoczna (zgromadzenie wezwanych, powołanych i wybranych) ukazująca się jako wspólnota braci, będąca w drodze do ostatniego i eschatologicznego spełnienia (wspólnota pielgrzymia). Równocześnie zachodzi komunia niewidoczna. Realizuje się ją przez wspólnotę tych, którzy rzeczywiście żyją jak bracia, udowadniają to przez oddawanie dóbr, wspólnotowe rozpoznawanie i braterskie upominanie. Zakłada się przy tym zjednoczenie w zgodzie i pokoju. Najpełniej idea komunii niewidocznej wyraża się podczas sprawowania Eucharystii.

Kościół jako diakonia (wspólnota posługiwania) realizuje się na zewnątrz poprzez charyzmaty dane dla dobra pogan, przykłady styl życia, oraz do wewnątrz przez posługę apostolską, prorocką, nauczycielską i pasterską.

Kościół jako martyria (wspólnota świadcząca) zakłada, iż świadectwo jest bardziej postawą wobec świata niż pełnioną służbą wychodzi na przeciw potrzebie wspólnoty i jej powołania misyjnemu.

Kościół jako soteria (wspólnota zbawiająca) konkretyzuje powszechną wolę zbawczą i jest efektywnym czynnikiem wyzwolenia duchowego całej ludzkości. 
Wspólnota jest pierwszą i podstawową komórką, która na właściwym sobie poziomie powinna wziąć odpowiedzialność za bogactwo i rozwój wiary, jest przy tym pierwszorzędnym czynnikiem ludzkiego awansu i rozwoju (158).

Wspólnotą jest taka grupa, w której członkowie znają się dogłębnie i akceptują na płaszczyźnie równości, ponad wszelkimi podziałami kulturalnymi, społecznymi, rasowymi, czy płci. Jest to miejsce, gdzie pan staje się sługą, a sługa panem. W niej wszyscy dzielą się tym czym są i co mają, przyjmuje się wszystkich i wszyscy ofiarowują bezwarunkową gotowość. Członkowie wspólnoty zwracają uwagę, że trzeba się kochać, pomagać sobie, przebaczać, przezwyciężać nienawiść, zamknięcie i izolację. Z pomocą tych wszystkich znaków wspólnota będzie się stawać prawdziwym domem braterstwa. Oczywiście opisany wyżej styl życia zderza się ze społecznym otoczeniem, bo większość ludzi organizuje swoje życie w inny sposób, na podstawie konkurencyjnego i konsumpcyjnego egoizmu. Wspólnota powinna pozostawać w takiej sytuacji ożywczym fermentem lub atrakcyjną alternatywą. Każda $\mathrm{z}$ tych dwu strategii jest ważna w miarę jak jest realizowany nadrzędny cel. Zjawisko wspólnoty zostało szeroko opisane z punktu widzenia nauk humanistycznych (zwłaszcza socjologii).

Wspólnota została w większości opracowań porównana do zgrupowania osób współzależnych i współdziałających ze sobą w sposób bezpośredni, głęboki i częsty oraz stały wokół wspólnego celu. Członkowie wspólnoty zawsze mają wyraziste poczucie własnego „My” i są bardzo zwarci w organizacyjnych ramach, gdzie istnieją normy, role i ideologia (159).

Wspólnota chrześcijańska rodzi się w procesie grupowym i opiera się na wartościach wziętych z wiary, w której się odnajduje. Ogólnie biorąc jest grupą osób lub zespołem grup, w których istnieją relacje pierwotne, braterskie i personalne, gdzie tkwi całość życia Kościoła wyrażonego w diakoni, liturgii i martyrii (160).

Tak ukazana wspólnota spełnia wymogi zarówno wizji pierwszych socjologów zajmujących się badaniem jej jako kategorii, jak również oddaje właściwie wizję Kościoła jako wspólnoty komplementarnych wspólnot podstawowych.

\section{Przypisy do rozdziału II}

1. F. Toennies: Wspólnota i stowarzyszenie, Warszawa 1988, s. 21.

2. Ibidem, s. 22-46.

3. Ibidem, s. 238.

4. Ibidem, s. 328.

5. J. Höffner: Chrześcijańska nauka społeczna, Kraków 1989, s. 24-26.

6. J. Szmatka: Małe struktury społeczne, Warszawa 1989, s. 65.

7. J. Szacki: Historia myśli socjologicznej, Warszawa 1983, s. 502-504.

8. Platon: Państwo, Warszawa 1958, 519E-520.

9. Arystoteles: Polityka, Warszawa 1964, w. 1252 b.

10. G. H. Sabine: A History of Political Theory, London 1963, s. 176. 
11. J. Szacki: op. cit. s. 51-52.

12. Augustyn: O Państwie Bożym, Warszawa 1977, s. 614, ks. XXII.

13. R. A. Nisbet: The Socjal Philosophers, New York 1973, s. 192.

14. J. Szacki: op. cit. s. 71.

15. J. Szacki: Ojczyzna, naród, rewolucja, Warszawa 1962, s. 33.

16. G. Missalowa: Francuski socjalizm utopijny, w: W stulecie Wiosny Ludów, Warszawa 1951, s. 7-165 t. III.

17. T. Dezamy: Kodeks wspólnoty, Warszawa 1977.

18. G. W. F. Hegel: Wykłady z filozofii dziejów, Warszawa 1958, s. 569 t. I.

19. J. Dewey: Demokracja i wychowanie, Wrocław 1972, s. 9.

20. J. B. Quandt: From the Small Town to the Great Community, New Brunswick 1970, s. 23-33.

21. J. Szacki: Historia ... op. cit. s. 592.

22. J. Mucha: Cooley, Warszawa 1992, s. 53-59.

23. M. Scheler: Istota i formy sympatii, Warszawa 1986, s. 235n.

24. J. Wach: Socjologia religii, Warszawa 1961, s. 48-59.

25. E. Hałas: Konwersja, Lublin 1992, s. 139-147.

26. E. Sujak: Rozważania o ludzkim rozwoju, Kraków 1987, s. 228.

27. J. Majka: Filozofia społeczna, Wrocław 1982, s. 353-361.

28. F. Adamski: Socjologia małżeństwa i rodziny, Warszawa 1984, s. 25-26.

29. S. Olejnik: Teologia moralna, Warszawa 1991, t. 5 s. 271.

30. K. Żygulski: Wspólnota śmiechu, Warszawa 1985, s. 19-40.

31. J. Bukowski: Zarys filozofii spotkania, Kraków 1987, s. 176-188.

32. A. Rodziński: Komunionistyczna wizja kultury, w: Człowiek w społeczności, Niepokalanów 1988, s. 15-23.

33. E. Sujak, op. cit. s. 228-230.

34. J. Sztumski: Społeczeństwo i wartości, Katowice 1992, s. 35-40.

35. T. Tomaszewski: Wstęp do psychologii, Warszawa 1963, s. 72-73.

36. J. Sztumski: op. cit. s. 43-53.

37. F. Adler: The Value Concept in Sociology, w: The American Journal of Sociology, 62(3) (1956) 272-279.

38. M. Misztal: Pojęcie wartości w socjologii, w: Studia socjologiczne 4/75. 
39. C. Buczek: Kategoria wartości w badaniach przemian społecznych, w: studia Sociologica, Szczecin 1992, s. 49-55.

40. E. Podrez: Człowiek, byt, wartość, Warszawa 1989, s. 53-130.

41. L. Leopold: Das Prestige, Berlin, 1916.

42. J. Sztumski, op. cit. s. 93.

43. C. Mills: Elita władzy, Warszawa 1961, s. 109-112.

44. T. Geiger: Führen and Folgen, Berlin 1928.

45. M. Weber: Wirtschaft und Gesellschaft, Tübingen 1956.

46. J. Sztumski: op. cit., s. 92-101.

47. J. Vanier: Wspólnota, Warszawa 1985, s. 59-73.

48. L. Giussani: Śladami chrześcijańskiego doświadczenia, Warszawa 1988, s. 13-98.

49. F. Blachnicki: Kościół jako wspólnota, Krościenko 1981, s. 11-29.

50. A. L. Szafrański: Kairologia, Lublin 1990, s. 170-182.

51. M. Żurowski: Współuczestnictwo kościelne, Kraków 1984, s. 172-209.

52. I Bokwa: Kościół jako wspólnota, w: Przegląd Powszechny 1/93, s. 30-39.

53. A. Skowronek: Misja, dialog, polskie tematy tabu, w: Więź 10/92, s. 79.

54. A. Przybecki: Urzeczywistnianie się Kościoła w środowisku akademickim, Poznań, 1986, s. $20-21$.

55. A. Zuberbier (red.): Słownik teologiczny t. 2, Katowice 1989 s. 377-380.

56. R. E. Rogowski: Światłość i tajemnica, Katowice 1986, s. 213.

57. Jan Paweł II: Christifideles Laici, w: Chrześcijanin a współczesność 2/89, 19-30

58. Niektóre aspekty Kościoła jako komunii, Krościenko 1993, s. 11-12.

59. J. Ratzinger: Kościół jako komunia, Krościenko 1993, s. 18-19.

60. M. Nowak: Kościół - wspólnota dla wszystkich, w: znak 9/90 s. 27-29.

61. J. Gołębiewski: Wybrane zagadnienia z teologii wspólnoty, w: Materiały synodalne diecezji Warszawsko - Praskiej, Warszawa 1993, zeszyt 3, s. 4-6.

62. Dzieło misyjne Kościoła w Polsce, w: Drugi Polski Synod Plenarny, Poznań 1991, s. 256-260.

63. F. Blachnicki, op. cit. s. 44-48.

64. M. Libiszowska - Żółtkowska: Postawy inteligencji wobec religii, Warszawa 1991, s. 25.

65. H. Carrier: Rola grup odniesienia w integracji postaw religijnych, w: Socjologia religii (red. F. Adamski), Kraków 1984, s. 152. 
66. Ibidem, s. 147.

67. Jan Paweł II: Posłanie do G. V. Coyne’a, w: Znak - idee, t. 5, Kraków 1993, s. 8-14.

68. J. Wach: Socjologia ... op. cit., s. 59-60.

69. Konstytucja duszpasterska o Kościele w świecie współczesnym w: Dokumenty Soboru Watykańskiego II-go, Poznań 1986, s. 555-556.

70. F. Blachnicki: op. cit., s. 83-92.

71. J. H. Fichter: Social Relations in the Urban Parish, Chicago 1954.

72. W. Piwowarski: Religijność wiejska w warunkach urbanizacji, Warszawa 1971, s. 252-294.

73. T. Żeleźnik: Człowiek w Kościele i w świecie, w poszukiwaniu jedności, w: Kościół, świat świeccy, Warszawa 1988, s. 147.

74. E. Weron: Powołanie i posłannictwo ludzi świeckich, Poznań 1989, s. 61-65.

75. H. Wistuba: Wspólnota parafialna, Olsztyn 1984, s. 16-19.

76. J. Słomińska: Mechanizmy i funkcje grup młodzieżowych, Warszawa 1986, s. 7-26.

77. E. Ozorowski: Kościół, Wrocław 1984, s. 59-60.

78. A. Ballestrero: Wspólnie z Bogiem, Kraków 1985, s. 73-74.

79. K. Brodzki, J. Wojna: Oazy, Ruch “Światło - Życie”, Warszawa 1988, s. 50-52.

80. J. Mariański: Kościół w społeczeństwie przemysłowym, Warszawa 1983, s. 45-50.

81. H. Łuczak: Wspólnota zbawienia, Warszawa 1990, s. 17-18.

82. A. Hartliński (red.): Nauka Soboru Watykańskiego II-go, Poznań 1986, s. 16.

83. L. Giussani: Śladami ... op. cit., s. 11-96.

84. J. Salij: Tajemnica Emmanuela dzisiaj, Poznań 1989, s. 25.

85. F. Houtart: Socjologia parafii jako Zgromadzenia Eucharystycznego, w: Ludzie, wiara,

Kościół (red. B. Cywiński) Warszawa 1966, s. 394-405.

86. G. Thils: Nowy wiek Kościoła, w: Życie Katolickie 5/85, s. 40.

87. S. Wilkanowicz: Kościół w nowej sytuacji, w: Znak 8/89, s. 29-32.

88. J. Wach: op. cit., s. 147-155.

89. Ibidem, s. 179-185.

90. E. Podrez: Osobowy i społeczny aspekt natury ludzkiej, w: Życie katolickie 1/85, s. 103-104.

91. F. Blachnicki: op. cit., s. 75.

92. S. Szczepaniec: Posługi dla świeckich w Kościele, Lublin 1992, s. 18-28. 
93. K. M. Ujazdowski: Jak realizować wartości chrześcijańskie w życiu publicznym, w: Więź 4/92, s. 22.

94. Nauka o Kościele i miejscu Matki Bożej w Kościele, w: Drugi Polski Synod Plenarny ... op. cit., s. 21-39.

95. J. Majka: Społeczna struktura parafii, w: Homo Dei 1964, t. 2, s. 82.

96. E. Ciupak: Kult religijny i jego społeczne podłoże, wyd. LSW 1965, s. 205-220.

97. A. Perzyński: Parafia w świetle teologii kościoła lokalnego, w: Dziś i jutro parafii (red. A. Lepa) Łódź 1991, s. 48-53.

98. T. Sikorski: Parafia dziś, w: Dziś i jutro ... op. cit., s. 119.

99. S. Olejnik: Teologia moralna, Warszawa 1988, t. 1, s. 227-229.

100. J. Majka: Katolicka Nauka Społeczna, Warszawa 1988, s. 414-420.

101. H. Seweryniak: Dziś i jutro Kościoła w Polsce, w: Przegląd Powszechny 2/92, s. 209-215.

102. J. Vanier: Wspólnota miejscem radości i przebaczenia, Warszawa 1991, s. 19-47.

103. R. Jaworski: Psychologiczne korelaty religijności personalnej, Lublin 1989, s. 22-24.

104. J. Kłoczowski: Katolicy Polscy wobec zadań dnia dzisiejszego, w: Znak 6/91, s. 82-86.

105. Z. Borowik: Wspólnota państwowa w nauczaniu S. Wyszyńskiego, w: Życie katolickie 7-8/84, s. 144-147.

106. J. Szamocki: Wspólnota wspólnot, w: Wieczernik 51/93 Poznań, s. 7.

107. B. Hume: Spotkanie Jasnogórskie, w: Jasna Góra 10/92, s. 10-12.

108. T. Gadacz: Kościół jest naszym wielkim wspólnym dobrem, w: Znak 11/91, s. 57-58.

109. C. J. Cyman: Działalność apostolska sióstr, a integracja ze wspólnotą zakonną, Warszawa 1990, s. 25-26.

110. J. Charytański: W kręgu zadań i treści katechezy, Kraków 1992, s. 217-229.

111. E. Szumańska: Wizja autentycznej wspólnoty, w: Kościół Polski na przełomie 2000 roku (red. T. Wołek), Poznań 1987, s. 172.

112. E. Puzik: O sztuce stawania się w naszym świecie świętym, Poznań 1988, s. 58-62.

113. R. Caldera: Co to jest chrześcijańska demokracja, Poznań 1990, s. 26-28.

114. H. Juros: Nowe zadania Kościoła w Polsce, w: Przegląd Powszechny 1/93, s. 13-20.

115. K. Wojtyła: U podstaw odnowy, Kraków 1988, s. 120-350.

116. E. Ciupak: Religijność młodego Polaka, Warszawa 1984, s. 80-81.

117. M. Gogacz: On ma wzrastać, Warszawa 1990, s. 176-178.

118. J. Mariański: Żyć parafią, Wrocław 1984, s. 92-98. 
119. E. Staniek: Bogactwo tajemnicy Kościoła, Kraków 1990, s. 5-9.

120. A. Borowski: Konwersja w instytucjach totalnych, Szczecin 1992 (maszynopis powielany), s. 1-9.

121. H. Grzymała - Moszczyńska: Psychologia religii, Kraków 1991, s. 64-71.

122. M. Libiszowska - Żółtkowska: Socjologiczne aspekty konwersji religijnej, w: Euhemer 4/91, s. 109-120.

123. A. Hartliński (red.): Nauka ... op. cit., s. 68-69.

124. J. Mariański: Kierunki badań polskiej socjologii religii w latach osiemdziesiątych, w: Życie katolickie 1/90, cz. 4, s. 63-68.

125. J. Szmatka: Jednostka i społeczeństwo, Warszawa 1980, s. 111-112.

126. R. Woźniak: Problemy struktur społecznych a badania socjologiczne, w: Koszalińskie studia 1982, s. 19-21.

127. R. Woźniak: Rozwój i zmiana struktur społeczności miast portowych, w: Rozwój i zmiany w społecznościach ziem zachodnich i północnych Polski, Szczecin 1991, s. $148-152$.

128. J. Ratzinger: Raport o wierze, w: Życie katolickie 12/85, s. 26.

129. B. Jałowiecki: Rozwój lokalny, Warszawa 1989, s. 307-310.

130. H. Grzymała - Moszczyńska: Nowe ruchy religijne, w: Oświata i wychowanie 1/85, s. 34-37.

131. H. Grzymała-Moszczyńska: Psychologia ... op. cit., s. 117-128.

132. Z. Pasek: Krakowska wspólnota modlitewna "Nowe życie" jako przejaw charyzmatycznej odnowy Kościoła, w: Studia Religiologica, Kraków 1986, zeszyt 15, s. $79-84$.

133. G. Danneels: Jak ewangelizować zsekularyzowaną Europę, w: Orientacje 4/14, Warszawa 1992, s. 14-15.

134. J. Michalik: Nie wierzę w konflikt pokoleń, w: Znaki czasu 17/90, s. 160-164.

135. S. Grygiel: Tożsamość poczętego dziecka, w: Znaki czasu op. cit., s. 183-184.

136. Drugi Polski Synod Plenarny ... op. cit., s. 56-247.

137. M. Nowaczyk: Nowe ruchy religijne, w: Euhemer 4/91, s. 7-13.

138. T. Doktór: Nowe ruchy religijne i parareligijne w Polsce, w: Euhemer 4/91, s. 100.

139. M. Libiszowska - Żółtkowska: Socjologiczne aspekty ... op. cit., s. 115-120.

140. Z. Stachowski: Kościół katolicki wobec nowych ruchów religijnych, w: Euhemer 4/91, s. 158.

141. J. Mariański: Kondycja religijna i moralna młodych Polaków, Kraków 1991, s. 85. 
142. J. Mariański: Kontrowersje wokół roli świeckich w parafii, w: Życie katolickie 7/87, s. $100-101$.

143. A. Lepa: Parafia wielkomiejska jako środowisko wychowawcze, w: Dziś i jutro parafii ... op. cit., s. 28.

144. S. Pyszka: Kościół katolicki w obliczu sekt i współczesnych ruchów religijnych, w: Horyzonty wiary, Kraków 1990, zeszyt 3, s. 6-9.

145. P. Cordes: Ducha nie gaście, Gorzów Wlkp. 1990, s. 75.

146. J. Mariański: Kościół w społeczeństwie przemysłowym, Warszawa 1983, s. 250-251.

147. A. Hartliński: Nauka ... op. cit., s. 134.

148. A. B. Francja - ku wspólnocie Ludu Bożego, w: Życie Katolickie 2/84, s. 85-92.

149. M. Przeciszewski: Pielgrzymka nadziei, w: Spotkania 18/91, s. 34.

150. M. Przeciszewski: Wspólnota wspólnot, w: Spotkania 27/91, s. 30.

151. Z. Nosowski: Między tradycją a wyborem, w: Spotkania 13/92, s. 22-24.

152. R. Rak: Od utopii marksistowskich do mistycznych, Lublin 1993, s. 21-22.

153. F. Toennies: Wspólnota ... op. cit., s. 239-240.

154. M. Eliade: Methodological Remarks of the Study of Religious Symbolism, London 1959, s. 99-102.

155. H. Schmalenbach: Communion a Sociological Category, Chicago 1977, s. 86.

156. J. Wach: Socjologia ... op. cit., s. 130.

157. E. Hałas: Konwersja ... op. cit., s. 147.

158. S. Movilla: Od katechumenatu do wspólnoty, Warszawa 1990, s. 145-150.

159. I. Hernandez: Caracters psicosociologicos de la Comunidad, w: Actualidad Catequetice 1979, s. 110.

160. A. Gregori: Comunidades Eclesiais de Base, Rio Petropolis 1973, s. 85. 


\section{POJECIE POKREWNE KATEGORII "WSPÓLNOTA"}

\section{1. Więź społeczna}

Problemem więzi społecznej, w sposób naukowy zaczęto się interesować w początkach XIX w. w związku z upadkiem systemu feudalnego w większości państw Europy i narodzinami kapitalizmu. Upadek dawnego ustroju był, zwłaszcza w oczach konserwatystów, swojego rodzaju rozwiązaniem społeczeństwa, a w każdym razie przyczyną jego głębokiego kryzysu. Kryzys ten dotyczył zwłaszcza tradycyjnych form więzi społecznej. Ujawnienie się wewnętrznych konfliktów nowej formacji społecznej, sprawiło, że idee konserwatystów zaczęły być wykorzystywane $\mathrm{w}$ analizie innej niż pierwotnie problematyki społecznej. W dziedzictwie myśli konserwatywnej zawarte były też ważne problemy socjologiczne, których nie można było po prostu odrzucić wzorem innych coraz mniej licznych epigonów Oświecenia. Cała socjologia XIX w. wielokrotnie do konserwatyzmu (bezpośrednio lub pośrednio) nawiązywała. Najbardziej żywotne okazały się przy tym konserwatywne idee związane z krytyką utopizmu i abstrakcjonizmu w filozofii społecznej, obroną historycznego punktu widzenia, podkreśleniem roli czynników irracjonalnych w życiu społecznym, ujmowaniem społeczeństwa jako "organizmu" rozumieniem więzi społecznej, uwydatnianiem małych grup, analizą religii pod kątem jej wpływu na integrację społeczeństwa (1).

W koncepcjach liberalizmu więź społeczna była ustanowiona przy okazji dbania o własny interes, kształtowana żywiołowo poprzez przyrodzone skłonności jednostek (2).

$\mathrm{W}$ poglądach jednego $\mathrm{z}$ socjalistów utopijnych więź społeczna występuje jako dobrowolne współdziałanie (3).

K. Marks pisał natomiast o konieczności przyrodzonej stosunków społecznych, które w społeczeństwie nie tyle zanikają, ile przybierają wyalienowaną postać stosunków rzeczowych (4).

Ewolucjoniści wskazali drogę rozwoju więzi społecznej od pokrewieństwa do zbiorowości terytorialnych (5).

E. Durkheim, twórca socjologizmu, dostrzegał niezwykłe zróżnicowanie i zmienność więzi społecznej, przenosząc problem stosunku między jednostką i społeczeństwem $z$ płaszczyzny filozoficznych generaliów, na płaszczyznę socjologicznych konkretów. Jego pochwała społeczeństwa jako siły czyniącej jednostkę człowiekiem w pełnym tego słowa znaczeniu nie jest pochwałą żadnego określonego ustroju społecznego (6).

Głównym tematem socjologii F. Toenniesa była więź społeczna. Podjął on próbę syntezy, w ramach jednego systemu, dwóch przeciwstawnych punktów widzenia: organicystycznego i atomistycznego. $Z$ punktu widzenia F. Toenniesa rozwiązanie jest możliwe przy założeniu dwuaspektowości natury człowieka, który nie jest wyłącznie istotą racjonalną, ani wyłącznie irracjonalną (7).

W socjologii G. Simmla więź społeczna zawiązuje się, rozwiązuje i powstaje na nowo w wiecznym, pulsującym strumieniu, który wiąże jednostkę nawet wówczas, gdy nie należy ona do organizacji w ścisłym sensie (8).

W początkach XX w. pojawiła się koncepcja L. Krzywickiego dotycząca społeczeństw terytorialnych. W znacznym stopniu koncentruje się ona na socjologicznej analizie przemian więzi społecznej (9).

S. Ossowski dokonał analizy więzi społecznej opartej na wierze we wspólność pochodzenia, poszukując czynników, które składałyby się na świadomość pokrewieństwa lub świadomość obcości, rzucając światło na zasady podziału przy klasyfikacji grup społecznych (10). 
Więź społeczna jest przeciwieństwem wolności pisał F. Toennies. Istnienie więzi pomiędzy ludźmi jest dla niego warunkiem wstępnym istnienia wszelkich zjawisk społecznych. Więź jest także czynnikiem warunkującym wolność jednostki. Wzajemna więź łącząca jednostki w masie ma charakter takiej identyfikacji, dzięki temu, iż mają one afektywną cechę wspólną, a jak można przypuszczać, cechą tą jest rodzaj więzi między nimi, a przywódcą masy (11).

W poglądach Z. Freuda wszelkie więzi na jakich opiera się jakakolwiek grupa, wynikają z popędów zahamowanych ze względu na cel. Dzięki mechanizmowi libido, więź łącząca jednostki $\mathrm{w}$ grupie ma charakter identyfikacji, lecz to co łączy je z przywódcą, to więź wynikająca z tego, że jednostka mając jakiś swój ideał ego, w momencie uczestnictwa w grupie rezygnuje zeń, zamieniając go na ideał zbiorowości ucieleśniony w przywódcy (12).

Więź społeczna przejawia się jako świadomość jedności społecznej z ośrodkiem, ale także w jedności z ludźmi, którzy tę jedność reprezentują. Świadomość więzi ujawnia się w przypadku każdej konfrontacji z innymi społecznościami, lub ich przedstawicielami, niezależnie od tego, czy będą to spory rodowe, czy też zawody sportowe. Więź społeczna może być w pewnych okresach przeżywana jednoznacznie przez całą grupę, kiedy świadomość wszystkich członków jest w jakimś szczególnym przypadku skupiona na jednym wysiłku, jednym niepokoju, jednej nadziei, jednym sukcesie, przeżywanym przez wszystkich jako wysiłek, niepokój, nadzieja, lub sukces całości względnie jednego z jej członków. Wszystkie przejawy więzi społecznej nie stanowią jej istoty, ale też nie są jedynie śladami jej istnienia, stanowią one na równi z innymi jej czynnikami element składowy tego złożonego splotu, który składa się na całość bytu społecznego, wypełniającego przestrzeń międzyosobową, część składową tego co stanowi rzeczywistość wspólnoty (13).

Więź powstająca w ramach wykonywanej pracy coraz wyraźniej sytuuje się na czele więzi społecznych. Zastępuje ona w wielu regionach świata słabnącą więź geograficzną, terytorialną, a nawet sąsiedzką. Rozwój techniczny rozbijając dotychczasowe rodzaje integracji podnosi znaczenie pracy jako czynnika nowej integracji (14).

W obecnych czasach, gdy ideologia liberalna zwycięża nowe wzory więzi społecznej, nowe idee suwerennej grupy społecznej, narody stały się bronią ruchów społecznych (15).

Więź społeczna występuje zawsze w określonej zbiorowości, czy jest nią grupa społeczna, czy społeczność nadrzędnego typu. W takiej zbiorowości istnieją dane, które stanowią realne podłoże łączącej ludzi więzi (16).

Więź społeczna nie może istnieć bez określonego podłoża, nie jest jednak jednoznacznie określona przez zawarte $\mathrm{w}$ nim dane. W dawnych teoriach istniało zawsze przekonanie, że istnieje tylko jeden typ więzi społecznej. W nowszych teoriach socjologicznych dokonał się pod względem pojmowania tego problemu postęp w dwóch kierunkach: problem więzi został przesunięty ze spekulatywnego typu rozważań nad genezą związków między ludźmi, na płaszczyznę systematyki socjologicznej. Po wtóre teoria socjologiczna doszła stopniowo do wydzielenia różnych typów (rodzajów) więzi społecznej. $\mathrm{W}$ teoriach najnowszych dochodzi do rozeznania, że w wielkich zbiorowościach mogą współwystępować różne rodzaje więzi. Pierwszy typ więzi ma swoje podstawy w korelatach życia zbiorowego, danych człowiekowi w sposób naturalny, przez same warunki urodzenia się W określonej zbiorowości. Taką więź można nazwać więzią naturalną. W tajnych związkach, stowarzyszeniach lub pół prymitywnych społeczeństwach tworzą się zaczątki innego typu więzi społecznej. Jest to więź, która urzeczywistnia się przez selekcję społeczną i dobrowolne łączenie się niektórych osób. Więź tego typu rozwija się w grupach zwanych zrzeszeniami, dlatego najbardziej adekwatną jest nazwa więzi zrzeszeniowej. Trzeci typ więzi społecznej powstaje również $w$ procesach selekcji społecznej i społecznego 
zróżnicowania. Nie jest to jednak więź, która łączy ludzi dobrowolnie się zrzeszających. Jest to więź niejako ludziom wyznaczona. Nazwana została więzią stanowioną. Powyższe trzy typy więzi społecznej nie zawsze jednak wyodrębniają się wyraźnie w rzeczywistości społecznej. Najlepszym tego przykładem jest inny podział na: Więź lokalną i terytorialną, czyli tę więź, której podstawę stanowi wspólne zamieszkanie określonego obszaru (17).

W rzeczywistości ludzkiej więź społeczna objawia się w dwóch płaszczyznach:

- wspólności interesów związków krwi między ludźmi, wspólne pochodzenie, terytorium, język, kultura w różnych jej dziedzinach i organizacja życia zbiorowego,

- stany i akty świadomości, poczucie szczególnej łączności z innymi ludźmi, poczucie wzajemnej z nimi współzależności, manifestacyjne okazywanie tego uczucia w postawach i zachowaniach zbiorowych i indywidualnych.

Zjawisko więzi społecznej można ujmować z wielu różnych punktów widzenia:

- genetycznie (podstawy na jakich więź jest zbudowana i dana ludziom - wspólnota etniczna, dom),

- stanowiona (państwo),

- zrzeszeniowa (organizacja dobrowolna) (18).

Pojęcie więzi społecznej w znaczeniu więzi religijnej obejmuje bardzo szeroki zakres znaczeń i w zasadzie odnosi się do wszystkich aspektów i form religijności. Tak rozumianą więź można ujmować zarówno w kategoriach teologicznych jak i socjologicznych. W pierwszym znaczeniu dotyczy ona stosunku człowieka do wartości inorm religijnych oraz stopnia ich internalizacji i zastosowania w praktyce życiowej, w drugim natomiast odnosi się do stosunków jednostki z instytucjami religijnymi i ze społecznością wierzących. Zasady współżycia społecznego są natomiast wyznaczone przez organizację życia religijnego, w środowisku, wreszcie system norm nakazów i zakazów, które regulują strukturę grupy wyznaniowej, postawy jej członków wobec jednostek i grup preferujących inne przekonania światopoglądowe oraz odmienne systemy wartości lub też inny ich układ (19).

\section{2. Integracja społeczna}

F. Boas jeden z przedstawicieli szkoły historycznej badał problem integracji kultury. Problem ten stał się w jego szkole ośrodkiem zróżnicowania się stanowisk (20). Wszyscy zgadzali się, że każda kultura tworzy określoną konfigurację, czy też posiada swoisty dla siebie wzór czy styl. Możliwe jednak były dwa podejścia: kulturalistyczne i psychologiczne. Oba np. występują w twórczości R. Benedict, która wyróżnia implicite dwa porządki czy poziomy tej integracji: $\mathrm{z}$ jednej strony porządek elementów kultury, $\mathrm{z}$ drugiej porządek postaw i emocji (21).

A. Kroeber i E. Sapir reprezentują te dwa podejścia do problemu integracji kultury w postaci niemal czystej (22).

F. Znaniecki stwierdza w swoim dziele "Nauki o kulturze", że wszak integracja kulturowa jakiejś zbiorowości zależy ostatecznie od społecznej organizacji (23).

Teoretyk ewolucji społecznej T. Parsons uważał, że ewolucja polega na podnoszeniu się zdolności adaptacyjnej społeczeństwa. Dochodzi do tego poprzez dwa procesy: dyferencjację $\mathrm{i}$ integrację. W jego rozumieniu proces integracji polega na wytwarzaniu się adekwatnych środków społecznej kontroli (24).

Jeden z twórców teorii konfliktu L. A. Coser chciał współczesnych sobie socjologów oswoić z myślą o doniosłej roli konfliktów w życiu społecznym, przez wskazanie, że przyczyniają się one również do wzrostu integracji społecznej. Była to rehabilitacja konfliktu w funkcjonalistycznym układzie odniesienia (25). 
J. Dewey uważa, że kultura jest fikcją, jeśli się ją rozpatruje w oderwaniu od uczestniczącej w niej jednostki. Integracja społeczna jest ostatecznie sprawą zgodności postaw jednostkowych (26).

Określenie integracja sprowadza się najogólniej do procesów scalania, łączenia, lub też oznacza zwartość, harmonijność. Scalenie integracyjne oznacza jedność w różnorodności. Od strony strukturalnej zintegrowany system społeczny określa się jako układ różnorodnych więzi spajających ludzi ze sobą na tle ich współuczestnictwa przy realizowaniu celów systemu. Integracja społeczna jako zjawisko jest cechą współżycia społecznego i występuje we wszelkiego typu zbiorowościach społecznych (zwłaszcza w grupach). Z pojęciem integracji zawsze wiąże się pojęcie więzi społecznej. Natomiast z pojęciem dezintegracji pojęcie wypadania z więzi społecznej. Współzależność więź - integracja jest tak ścisła, że P. Blau mówi o więziach integracyjnych, gdy pisze o siłach łączących jednostki w zwartą całość (27).

L. Krzywicki nazywa więzi społeczne - integracją, czyli wspólnotą uczuć, idei wynikających z biologii człowieka (28).

$\mathrm{O}$ integracji grupy decyduje charakter stosunków społecznych wynikających i stanowiących źródło więzi. Źródła integracji są wielorakie, ale ogólnie można powiedzieć, że istnieją czynniki zewnętrzne i wewnętrzne. Do czynników zewnętrznych porządkujących grupę zalicza się te, które mają miejsce w grupach typu instytucjonalnego. W grupach celowych, w których występują określone struktury, hierarchie, przestrzeganie norm, są wpływ kontroli społecznej, począwszy od percepcji prawnej do opinii publicznej. Należyte funkcjonowanie grupy społecznej zależy od właściwej hierarchii, od zintegrowanej zbiorowości poszczególnych jej członków. W. S. Landecker wyróżnia cztery typy integracji:

- integrację kulturową (wynikającą z kierowania się wzorami kultu),

- integrację normatywną (przystosowanie się osób do norm),

- integrację komunikatywną (wymiana znaczeń informacji w grupie),

- integrację funkcjonalną (wymiana usług we wspólnocie) (29).

W polskiej literaturze socjologicznej pojawiły się dwa nurty różniące się ujmowaniem i badaniem integracji. Pierwszy cechowały badania $\mathrm{i}$ analizy początkowo głównie nad przeobrażeniami na ziemiach zachodnich, później objęto nimi procesy zachodzące w miastach i wioskach. Nurt ten cechowało ujmowanie integracji jako procesu: tworzenia się przekształcania (reintegracja) albo narastania więzi doprowadzającego do osiągnięcia stabilizacji życia społecznego i kulturalnego określonej zbiorowości lub przyczyniającego się do ujednolicenia różnicowanych elementów całości. Polegała też na tworzeniu $\mathrm{z}$ agregatu takiej całości, w której wystąpi zgranie działań członków. Poziom zgrania uznano za wskaźnik zaawansowania procesów integracyjnych. Rodzimy nurt socjologii wypracował ujęcie integracji jako procesu stawania się, trwania i przeobrażania więzi społecznej. Podjął on zagadnienia powstawania i przekształcania spontanicznych stosunków społecznych, rodzenia się i przeobrażania stosunków wyznaczonych organizacyjnie, wytwarzania się instytucji regulatywnych, wysuwania, stawiania i realizacji wspólnych zadań, wyłaniania się przywódców lokalnych, przenikania się gwar, kształtowanie się postaw wobec uformowanych instytucji, tworzenie opinii publicznej, kształtowanie odniesienia się do przestrzeni jako wartości (30).

M. Ossowska stwierdziła, że pojęcie integracji i dezintegracji charakteryzuje się przez rodzaj panujących stosunków społecznych, przez niezdolność czy zdolność do kooperacji, lekceważenie norm czy zgodne ich wypełnianie, odmienny czy wspólny zasób wartości, wzajemną ufność czy brak zaufania, poczuwanie się do odpowiedzialności za cudzą 
pomyślność lub nie. Uważała ona, że odpowiednikiem pojęcia integracji w nauce o moralności jest pojęcie harmonii społecznej (31).

J. Szczepański sformułował własną definicję integracji. Dla każdego zbioru obiektów o określonej lokalizacji przestrzennej i czasowej, jeżeli pojawiają się w ich obrębie agregaty, czy między nimi proces tworzenia zorganizowanej zbiorowości, zdolnej do spełnienia określonych zadań, skupionej więzią nieantagonistycznych stosunków, w której elementy przystają do siebie, gdyż zharmonizowały swoje dążenia nie tylko przez tworzenie wspólnych instytucji formalnych, lecz przez wytworzenie wspólnych wartości, wzorów działania, interesów i poglądów, to mamy do czynienia ze stanem lub procesem integracji naturalnym procesem wytwarzania się całości (32).

Drugi nurt rozważań nad integracją wyłonił się w Polsce w następstwie przenoszenia przez socjologów organizacji i zarządzania pewnych analiz i wzorów badawczych z USA. Ten nurt ujmował integrację z perspektywy prakseologicznej, włączając w obręb refleksji nad nią zasadnicze kryterium - coraz pełniejsze przyczynianie się do powodzenia całości (33).

Istotą systemowych ujęć integracji jest koordynacja, uzgadnianie dotyczące jednostek, zbiorów, czy innych części składowych danej całości społecznej (34).

W. Jacher opracował własną oryginalną wersję pojęcia integracja społeczna. Oznacza ono (u niego) proces zespalania trwałymi więzami społecznymi zbiorowości ludzkich, realizujących określone wartości i cele działania. Jest to proces złożony i wielowymiarowy. Prowadzi do dynamicznego stanu struktury społecznej, gdyż uruchamia różne elementy systemu społecznego.(brak oryginału by poprawić) Integracja dokonuje się na różnych płaszczyznach życia społecznego, a więc na płaszczyźnie kultury i wzorów kulturowych, postępowania wyrażającego swoiste uzgodnienie między normami, a zachowaniami osób i grup, podziału pracy i ról, funkcji w grupie zgodnie z zajmowanymi pozycjami społecznymi i celami systemu społecznego, a także komunikacji międzyludzkiej, informacji oraz wymiany zachowań (35).

Oddziaływanie integracyjne np. zakładu pracy może obejmować swoim zasięgiem różne grupy społeczne, poczynając od własnej załogi poprzez środowisko lokalne, aż do zbiorowości reprezentujących szersze kręgi społeczne. Specyfika funkcji integracyjnych zakładu może także być dodatkowo uwarunkowana różnymi elementami: zróżnicowania strukturalne, etniczno - kulturowe, specyfika środowiska, wielkość środowiska lokalnego i zakładu pracy (36).

Po to, aby dokonała się całkowita integracja ludzi na świecie, w historii musiały nastąpić trzy okresy: cierpliwej proletaryzacji, solidarności w walce klas oraz zaczynającej się integracji w społeczeństwo (37).

Poziomy integracji świata społecznego wzajemnie się warunkują i determinują. Oznacza to, że właściwości i funkcjonowanie działających jednostek jest zdeterminowane właściwościami mikro i makrostruktur. Te ostatnie mają wpływ jedynie pośredni (38).

Z. Dulczewski twierdzi, że po wytworzeniu się więzi lokalnej następuje jeszcze integracja społeczna polegająca na określaniu członków tych samych zbiorowości terytorialnych mianem "My", w odróżnieniu od członków sąsiednich grup terytorialnych. Rezultatem wytworzenia więzi lokalnej i integracji społecznej uzupełnionych zainteresowaniami dla tradycji historycznej własnego osiedla, i ambicji przodowania kulturalnego oraz gospodarczego (swoistego patriotyzmu lokalnego) (39).

Praca zawsze była czynnikiem integracji społecznej. Obecnie zaś warunki i sposób jej wykonywania czyni z niej wyraz i czynnik uspołecznienia o znaczeniu wprost wyjątkowym. Technika współczesna zmieniając warunki pracy żąda współdziałania w ciągu 
technologicznym całych wielkich zespołów ludzkich, stara się także to współdziałanie kształtować (40).

Społeczna integracja postrzegana jako proces przekształcania się zbiorów jednostek we wspólnoty, czy zrzeszenia, bądź jako stan zwartości, spójności wzajemnej zależności, współdziałania oraz identyfikacji członków $\mathrm{z}$ grupą jest przedmiotem zainteresowania socjologów od początków naukowej analizy społeczeństwa (41).

Wskaźnikiem integracji rodzinnej może być natężenie rozwodów w obrębie społeczności. Wskaźnik taki mówi nam o przemianie zachodzącej we wzorach i normach kulturowych, Pożycie rodzinne jest szczególnie silnie poddane kontroli społecznej. Fakt jego normalnego rozpadu można traktować jako pośredni wskaźnik integracji kulturowej (42).

Przy studiowaniu rozmaitych podejść do zagadnienia integrującego oddziaływania religii, funkcjonalista wprowadza rozróżnienie. Stoi na stanowisku, że nie należy przyjmować za tożsame mocno ugruntowanego stwierdzenia, że dla utrzymania spójności społeczeństwa niezbędny jest jakiś integrujący system wierzeń i praktyk. Inne zaś stanowisko głosi, że istniejący w konkretnym przypadku system przyczyniania się do społecznej integracji (43).

Kościół będąc z natury swej znakiem jedności zawsze spełnia integracyjną funkcję w życiu narodu, któremu głosi orędzie. Na przykład chrzest Polan spowodował rozwój kultury chrześcijańskiej na ziemiach polskich i zapoczątkował proces integracji narodowej. Chrześcijaństwo przyniosło ze sobą nowe pojęcie państwa, co miało istotne znaczenie dla procesu integracji narodowej. Kościół starając się w różny sposób integrować naród, w szczególny sposób zwracał uwagę na jedność polityczno - prawną, czego wyrazem było zbliżenie władców świeckich i osób duchownych (44).

\section{3. Solidarność spoleczna}

Solidarność jest skłonnością członków grupy do popierania raczej działań grupowych, niż do przeciwstawiania się grupie. Tak rozumiana solidarność może być efektem dążenia wielu czynników w obrębie grupy, między innymi jest wywołana wysokim stopniem spójności i homogeniczności grupy. Niewątpliwie wpływ na wzrost lub spadek stopnia solidarności grupowej ma także określony stan struktur socjometrycznych. Wysoki stopień solidarności grupowej oraz znaczny stopień homogeniczności małych grup istotniej modyfikuje wzajemne oddziaływanie między mikro i makrostrukturami, prowadzi generalnie rzecz biorąc do wzmocnienia procesu przepływu informacji, ułatwiając tym samym szerszej strukturze wywieranie wpływu na małe grupy. Czynnik ten pozwala przekraczać bariery strukturalne i poszerzać wolność przez oddziaływanie na otaczające ich struktury (45).

Powtarzając dzisiaj i odmieniając na różne sposoby słowo solidarność musimy uświadomić sobie, jakie właściwie przysługują temu terminowi konotacje. Solidarność to przecież nie tylko nazwa konkretnego związku zawodowego, ale także jedna $\mathrm{z}$ podstawowych zasad życia społecznego głoszona przez Kościół. Tradycyjny model solidarności zrodził się w obliczu świata pracy i kapitału, polegał onna jedności między pracownikami. Jego ograniczenia wynikają z przejęcia koncepcji bezwzględnej opozycji pewnych sił społecznych, co zmusza je do podjęcia bezkompromisowej walki. Do istoty pracy, jak przypomina Jan Paweł II, należy prymat osoby ludzkiej nad rzeczami, pracownika nad ekonomią. Dążenie do przywrócenia tego naturalnego porządku papież uważa za drugą szczególnie pożądaną formę solidarności (solidarność ze światem pracy). Trzecią formą solidarności jest zdaniem papieża istnienie i współpraca stowarzyszeń partnerów społecznych. Koncepcja ta łączy się ściśle z ideą partnerstwa społecznego. Tak pojęta solidarność domaga się swobodnego traktowania działalności wszelkich organizacji (w tym 
związków zawodowych). Swoją koncepcję solidarności Jan Paweł II określił, jako koncepcja solidarności otwartej i dynamicznej, wznoszącej się ponad granice dzielące narody oraz grupy społeczne, poszukującej swej ostatecznej sankcji w naturalnej godności osoby ludzkiej i pracy pojętej jako akt odnajdywania sensu człowieczej egzystencji. Postawa solidarności umotywowana jest naturalną otwartością człowieka na drugą osobę, z którą współdziałać należy w dążeniu do dobra wspólnego. Człowiek solidarny nie tylko nie tylko sumiennie wywiązuje się z powierzonych mu obowiązków, lecz także stara się dostrzegać i rozumieć potrzeby wspólnoty, aby w miarę swoich możliwości coraz pełniej i prawdziwiej stawać się darem dla innych. Solidarność stwarza podstawy trwałych form społecznych, co nie oznacza bynajmniej uporczywego obstawania przy ustalonych schematach, przeciwnie w określonych sytuacjach wymaga ona przeobrażania zastanych kształtów życia społecznego, po to aby zachowana została wartość bardziej istotna (46).

Solidarność pojawia się jako propozycja wspólnoty. Ta ostatnia jest rzeczywistością mającą swe fundamentalne źródło w rzeczywistości nadprzyrodzonej. Solidarność staje się znakiem jedności wśród zatomizowanego świata. Solidarność, to wspólny trud skierowany ku poszanowaniu godności człowieka i budowaniu międzyludzkiej wspólnoty. To trud zmierzający ku wprowadzeniu większej sprawiedliwości, szczerego braterstwa, bardziej ludzkiego uporządkowania powiązań społecznych (47).

Solidarność powinna iść przed walką, wówczas ludzkość może przetrwać. Solidarność jest sposobem bytowania w wielości ludzkiej, w jedności uszanowania wszystkich różnic, wszystkie odmienności jakie między ludźmi zachodzą. Solidarność również wyzwala walkę, ale nie człowieka przeciwko drugiemu. Jest to walka o prawa człowieka, o jego prawdziwy rozwój (48).

W poglądach E. Durkheima, pojęcie społeczeństwa wydawało się nazbyt szerokie. Tym co istnieje realnie są szczególne formy solidarności: solidarność rodzinna, zawodowa, narodowa, wczorajsza, dzisiejsza itp. Każda z nich ma swoją własną naturę, toteż twierdzenia ogólne mogą w najlepszym razie dostarczyć wyjaśnień nader niekompletnych, gdyż nieuchronnie pozwalają umknąć temu co konkretne i żywe. Społeczeństwo nie jest wewnętrznie zróżnicowane, i tym samym jego związek z jednością jest bezpośredni. Solidarność istniejącą $\mathrm{W}$ tego rodzaju społeczeństwach można nazwać solidarnością mechaniczną. Jest ona odwrotnie proporcjonalna do stopnia zróżnicowania i ujednostkowienia społeczeństwa. Solidarności takiej, opartej na podobieństwie jednostek, odpowiada struktura społeczna będąca systemem segmentów homogenicznych i podobnych do siebie. Społeczeństwa o przewadze prawa kooperacyjnego tym się bowiem odznaczają, że podstawą solidarności jest w nich nie podobieństwo lecz podział pracy. O ile w społeczeństwach opartych na solidarności mechanicznej, imperatywem kategorycznym jest zasada: "rób to co robią wszyscy", o tyle tutaj panuje zasada: "Bądź w stanie z pożytkiem wypełniać określoną funkcję". Podzielona praca wymyka się spod kontroli świadomości zbiorowej. Jednostki są solidarne, dlatego, że są różne i wzajemnie się potrzebują. Taką solidarność E. Durkheim nazywa solidarnością organiczną. Jest ona wprost proporcjonalna do stopnia zróżnicowania i ujednostkowienia społeczeństwa, jako system różnych organów, z których każdy ma specjalną rolę i sam się składa ze zróżnicowanych części (49).

Ważnym zadaniem chrześcijan $\mathrm{w}$ dobie obecnej jest przyczynianie się do wzrostu integracji społecznej (solidarności). Solidarność jest podatnym gruntem dla miłości, i otwiera do niej drogę. Pracując wspólnie z innymi żyje się także ich życiem, dzieli z nimi problemy, radości i smutki, sukcesy i niepowodzenia. To bardzo zbliża ludzi, wiąże serca, wolę, rodzi braterstwo i solidarność (50). 
W Kościele będący jedni dla drugich współbraćmi w wierze powinni świadczyć sobie wzajemnie usługi wedle różnych darów sobie udzielonych. Tą solidarność będzie trzeba ciągle zwiększać, aż do dnia gdy osiągnie ona pełnię (51).

Apostołowie dążąc do wspólnoty braterskiej doszli do zjednoczenia serc, do podziału dóbr. Idąc za śladem swego Mistrza z Nazaretu, który poszukiwał nowych relacji między sobą a ludźmi, więzi solidarności, która pozwala stawać się grupie ludzi prawdziwą wspólnotą (52).

Jak wszelkie doświadczenie, fakt wspólnych lub równoległych doświadczeń religijnych w obrębie grupy działa jak potężna siła integrująca (spajająca). Również motywy samoobrony lub propagacji odgrywają rolę w wytwarzaniu poczucia solidarności, która jednoczy wszystkich członków (53).

Zasada solidarności nie umiejscawia się pośrodku drogi między indywidualizmem, a kolektywizmem, lecz skoro jest równocześnie zakorzeniona w godności osoby, stanowi zupełnie nowe i specyficzne stwierdzenie stosunku między jednostką i społeczeństwem. $Z$ drugiej strony jest ona zakorzeniona w jedności i we wzajemnej więzi ontycznej, istniejącej od samego początku między jednostką, a społeczeństwem, z drugiej zaś strony zasadą wyrażającą odpowiedzialność moralną wynikającą z tejże rzeczywistości ontycznej, stąd też jest jednocześnie zasadą ontyczną i etyczną. Zasada solidarności została naukowo przedstawiona i uzasadniona przede wszystkim przez H. Pescha, G. Gundlacha i O. Nell Breuninga, którzy nadali swojemu socjologicznemu systemowi miano solidaryzmu $\mathrm{z}$ wyraźnym zamiarem przeciwstawienia krótkiego i precyzyjnego słowa hasłom indywidualizmu i socjalistycznego kolektywizmu (54).

We wskazaniach Soboru Watykańskiego II solidarność jest zaliczana do głównych obowiązków dzisiejszego człowieka. Im bardziej jednoczy się świat, tym bardziej zadania ludzi przekraczają ramy partykularnych grup i powoli rozciągają się na cały świat. O tej solidarności decyduje w każdym zakresie, również tym najszerszym, postawa moralna każdego człowieka, jego cnoty moralne i społeczne (55).

\section{4. Jedność}

Najgłębszą podstawą światowego pokoju nie jest system tworzenia się bloków, ani równowaga zbrojeń lecz duchowa jedność ludzi i narodów. Świadomość istnienia światowej jedności między wszystkimi narodami staje się coraz silniejsza pomimo pewnych wyjąatków. Proces jednoczenia się świata (Europy) stanowi wyzwanie dla Kościoła, który zawsze opowiadał się po stronie katolickości (powszechności) lecz zbyt długo pozostawał zamknięty w obrębie chrześcijańskiego Zachodu (56).

Uczestnictwo jako sposób bycia w Kościele jest sposobem realizacji posłannictwa chrześcijańskiego w świecie. Jest to bycie z człowiekiem, udział w jego losie. Odpowiada to jak najbardziej powołaniu chrześcijańskiemu, którego konsekwencją w planie moralnym jest poczucie więzi braterskiej (jedności) ze wszystkimi ludźmi (57).

Stolice Apostolskie, czyli miejsce, gdzie Apostołowie rozwijali swoją działalność stały się miejscami jednoczenia całego Kościoła materialnymi symbolami duchowej jedności (58).

Jedność wspólnotowa jest darem łaski, polega ona na braniu udziału w zaradzaniu potrzebom braci oraz współdziałaniu w posłudze. Nieodzownym warunkiem i zasadą jedności wiernych jest już od pierwszych chwil tworzenia się wspólnoty, sprawa wiary, jak również sakramentów. Chrzest włącza ludzi we wspólnotę wiernych, natomiast inne pozwalają na drodze do budowania jedności wytrwać. Cały kult w każdej religii ma za zadanie budowanie jedności poprzez wspólne przeżywanie prawd wiary (59). 
W dokonanej powyżej analizie dokumentów soborowych wyraźnie została ukazana perspektywa i zasadnicza linia w rozwiązywaniu problemu: Kościół jako wspólnota jest sakramentem jedności, jest znakiem tej koinonii, które jest zdaniem całej ludzkości, jest też narzędziem do jej osiągania. W oparciu o jedność chrześcijan dokonuje się wyraźnie i dopełnia proces budowy jedności całej rodziny ludzkiej (60).

Powszechność Kościoła oznacza z jednej strony podstawową jedność, a z drugiej strony wielość i zróżnicowanie, które nie przeszkadzają jedności, ale nadają jej charakter komunii. Promocja jedności, która nie przeszkadza różnorodności i promocja zróżnicowania która nie przeszkadza jedności ale ją ubogaca, jest podstawowym zadaniem papieża wobec całego Kościoła i każdego biskupa w Kościele partykularnym. Budowanie i strzeżenie jedności, która dzięki różnorodności zyskuje charakter komunii jest także zadaniem wszystkich w Kościele, ponieważ są oni powołani by ją kształtować i zachowywać każdego dnia, przede wszystkim przez miłość, która jest więzią doskonałości (61).

Każdego człowieka, którego spotykamy na swej drodze musimy uznawać za kandydata do jedności. Skoro jesteśmy powołani do jedności, nasza droga do wieczności prowadzi przez drugiego człowieka. Jedność między ludźmi powstaje na zasadzie związku osób zatracających się w jedności z Bytem nadprzyrodzonym (Bogiem) (62).

Kościół chce budować jedność także z tymi, którzy nie budują jej pod zwierzchnością biskupa Rzymu. O tym świadczyć może otwarcie się Kościoła na działalność ekumeniczną (63).

Najistotniejsza cecha wschodniego poglądu na świat, a można powiedzieć, jego esencja, to świadomość jednostki i wzajemnego powiązania wszystkich rzeczy, doświadczenie wszystkich zjawisk w świecie, jako manifestacji podstawowej jedności. Podstawowa jedność świata jest nie tylko centralną cechą doświadczenia mistycznego, ale jest jednym z najważniejszych odkryć nowoczesnej fizyki (64).

Wspólnota ludzi w Kościele jest potężnym zalążkiem tej jedności, która będzie rozwijać się przez wieki, aż osiągnie miarę pełnej dojrzałości. Dlatego nie jest ona stanem lecz żywym procesem. Ten proces jednoczenia ludzi ma się rozwijać zarówno w indywidualnych kontaktach pomiędzy nimi, jak i we wspólnotach rodzinnych, wielkich wspólnotach społecznych, narodowych i międzynarodowych. Mozolność tworzenia jedności wynika przede wszystkim $\mathrm{z}$ tego, że każdy człowiek żyjący na ziemi nosi w sobie wewnętrzne rozdarcie i zamęt. Bez codziennego trudu, by trwać z ludźmi w jedności i stale ją na nowo budować groziłby Kościołowi rozłam między głoszonymi zasadami, a praktyką codziennego życia (65).

Jedność Kościoła można rozumieć w sensie jedyności, wykluczenia podziałów i odrębności od świata. Jedność ta opiera się na nadprzyrodzonych wewnętrznych więzach, a zarazem realizuje się w zewnętrznych widzialnych formach. Kościół już jest jeden. Swą jedność zdobywa jakby ciągle na nowo i umacnia w codziennym życiu swych członków. Kościół nie jest cielesnym organizmem. Jest wspólnotą osób zjednoczonych ze sobą na podobieństwo członków w ciele (66).

\section{5. Consensus}

Jednym z pierwszych autorów, który poruszał kwestię consensusu był św. Augustyn. Robił to przy okazji swego, największego dzieła "Civitas Dei". Porównał w nim państwo Boże i ziemskie. Wskazał przy tym na dwa odmienne systemy wartości jakimi podbudowane są te dwa państwa. Odpowiadają tym systemom dwa rodzaje ładu społecznego: konfliktowy i consensusowy. Twórca współczesnej teorii socjologii - A. Comte uważał, że jest ona jedyną nauką społeczną, nie ze względu na to, iż autor nie zastanowił się nad innymi, lecz dlatego, 
że świadomie kwestionował ich sensowność ze względu na powszechny consensus organizmu społecznego, który sprawia, że niemożliwe jest naukowe badanie społeczeństwa, czy to z punktu widzenia jego warunków, czy to z aspektu zachodzących w nim procesów, jeżeli dzieli się je na części i każdą z nich bada osobno. Statyka społeczna zajmuje się metodycznym badaniem porządku społecznego, czyli związkami wzajemnymi między różnymi częściami społecznego systemu i tym samym czynnikami kształtowania się społecznego consensusu. Główne założenia socjologii A. Comte’a, zwłaszcza jego teorii postępu mimochodem zostały już wspomniane. Rozwój społeczny ma charakter prawidłowy. Najważniejszym prawem jest prawo trzech stadiów: teologicznego, metafizycznego i naukowego wyjaśniania świata, zgodnie z zasadą wzajemnej zależności między wszystkimi częściami systemu społecznego (consensus). Przemiany świadomości, których bezpośrednio dotyczy wymienione prawo są skorelowane z przemianami we wszystkich dziedzinach życia społecznego. W ślad za Comtem dzielił socjologię na statykę i dynamikę społeczną J. S. Mill. Operował on rozwiniętą przez Comte'a koncepcją społecznego consensusu twierdząc nawet, że ów consensus jest tak pełny (szczególnie w dziejach nowożytnych), że w filiacji między jednym, a drugim pokoleniem jedna całość wywołuje drugą bardziej niż część wywołuje część. Dla J. S. Milla zjawisko nazwane consensus stanowiło zachętę do poszukiwania naturalnej korelacji między różnymi składnikami stanu społecznego. Taka korelacja (prawo natury) zachodzi np. pomiędzy formą rządów jaka istnieje w jakimś społeczeństwie, a jednoczesnym stanem cywilizacji. H. Spencer uważał, że wszystkie instytucje są ze sobą ściśle powiązane, tworząc jeden system społeczny, którego funkcjonowanie zależy od współdziałania poszczególnych części i podsystemów. Pomiędzy tymi częściami, powiada Spencer, istnieje consensus i naruszenie którejkolwiek z nich może zakłócić funkcjonowanie całości.

Wizja społeczeństwa jako wspólnoty w poglądach J. Deweya zawiera pewną nowość. Polega ona na przeniesieniu punktu ciężkości z rozważań o consensusie jako atrybucie społeczeństwa, na rozważania o procesie powstawania wspólnoty myśli i uczuć w toku interakcji między jednostkami. R. E. Park pisał, że społeczeństwo obejmuje coś więcej niż konkurencyjną współpracę i wynikającą z niej ekonomiczną współzależność. Istnienie społeczeństwa zakłada pewien stopień solidarności, consensusu, jakiś cel wspólny. Comtowski termin consensus nie jest tu może najfortunniejszy, tym bowiem co powołuje do życia społeczeństwo nie jest stan współodczuwania, lecz dwa procesy, z których jeden (właśnie współodczuwania) umożliwia, drugi zaś sam staje się dzięki niemu możliwy: komunikowanie się i działanie zbiorowe. W tym punkcie Park nawiązuje bezpośrednio do pragmatyzmu społecznego. Dla funkcjonalistycznej perspektywy charakterystyczne miałoby być w szczególności dostrzeganie stabilności społeczeństwa, ale nie jego zmiany, consensusu, ale nie konfliktu, konformizmu, ale nie twórczości, siły wiążącej normy, ale nie mechanizmów ich ustanawiania, bądź zastępowania przez inne (67).

Jedną z metod decydowania, która zmierza do zapewnienia małej grupie uczestnictwa $\mathrm{w}$ procesie decydowania nawet $\mathrm{w}$ grupach o znacznych wielkościach jest metoda consensusu. Grupy wykorzystujące consensus, w przeciwieństwie do zasady głosowania większością próbują powiązać wszystkie najlepsze intencje i intuicje swoich członków do znalezienia rozwiązania, które połączy w sobie wszystkie aspekty. Przykład zastosowania takiej metody podał A. P. Hare w swojej pracy "Wielkość grupy a consensus". Członkowie grupy wypowiadają opinię o problemie. Problemy są dyskutowane aż do momentu znalezienia rozwiązań, które łączą wszystkie punkty widzenia dla wszystkich członków dyskusji zadowalające. Członkowie próbują formułować rozwiązania, które będą osiągały consensus (zgodę wszystkich). Wszystkie uwagi są adresowane do grupy jako całości, po zezwoleniu 
koordynatora (nie bezpośrednio do członków grupy). Koordynator nie opowiada się za lub przeciw jakiemuś rozwiązaniu. On pomaga grupie dojść do consensusu przez formułowanie propozycji, które będą możliwe do przyjęcia przez wszystkich członków (to jest istota spotkania). Protokolant notuje propozycje, które wydają się reprezentować consensus i czyta je grupie tak, aby członkowie grupy mogli potwierdzić zgodność lub zmodyfikować propozycję (68).

\section{6. Społeczność (community, Gemeinwesen)}

Pierwsze wzmianki na temat społeczności jako kategorii socjologicznej pojawiły się przy okazji rozważań nad greckimi Polis (państwami - miastami) (69).

Dopiero w myśli społecznej XVII w. zaczyna się ponownie pojawiać kwestia społeczności. Problematykę grup społecznych rozwinął najobszerniej w tym czasie Althusius, który wyróżniał takie poziomy symbiozy jak rodzina, następnie bractwo (Genossenschaft), społeczność (Gemeinde), prowincję i państwo (70).

W dorobku C. Cooleya grupy pierwotne, w których jednostka uczestniczy w "heart-toheart-life", a więc: rodzina, grupa rówieśnicza czy sąsiedzka oraz społeczność lokalna, zostały przez niego uznane za piastunki ludzkiej natury i główne ośrodki socjalizacji jednostek (71).

Mówiąc o społecznościach, zwłaszcza lokalnych, dokonujemy pewnego ujednoznacznienia terminu "community", który ma znacznie bardziej bogatszą aurę skojarzeniową, niż jego polski odpowiednik. G. A. Hillery, który dokonał przeglądu olbrzymiej literatury $\mathrm{z}$ tej dziedziny szukając w niej definicji community - twierdzi, iż znakomita większość badaczy przypisuje społeczności lokalnej trzy zasadnicze cechy: terytorium, interakcję społeczną oraz istnienie trwałej więzi między jej członkami. Wyobrażenie community (społeczności lokalnej), jest nierozłączne z ludzkimi działaniami, celami i wartościami. Wyraża ono naszą mglistą tęsknotę za wspólnotą pragnień, za zjednoczeniem się z ludźmi dookoła nas, za rozciągnięciem więzi pokrewieństwa na wszystkich, $\mathrm{z}$ kimkolwiek połączyłby nas los. Community graniczy $\mathrm{z}$ jednej strony $\mathrm{z}$ pojęciem pewnego ładu społecznego i moralnego jaki istnieje w greckiej polis, czy też jaki Toennies przypisywał typowi idealnemu Gemienschaft (72).

Społeczność jako kategoria socjologiczna była badana w kilku orientacjach teoretycznych. Orientacja typologiczna ujmowała społeczność jako reprezentację szerszych kategorii stosunków, czy też grup ludzkich, połączonych zwykle z umieszczaniem ich w określonych punktach skali, której punktami krańcowymi byłyby wieś i miasto, grupa pierwotna i wtórna, lokalizm i kosmopolityzm, wspólnoty i spółka. Osobliwością orientacji ekologicznej zapoczątkowanej przez C. J. Galpina (twórcy amerykańskiej socjologii wsi), rozwiniętej przez szkołę chicagowską, było uprzywilejowanie badań społeczności lokalnej z aspektu wpływu, jaki na jej strukturę i rozwój wywiera środowisko przyrodnicze. Osobliwością orientacji strukturalno - funkcjonalnej, było położenie szczególnego nacisku na ujęcie społeczności lokalnej jako powiązanego wewnętrznie systemu. Do bardziej znanych koncepcji pochodzących $\mathrm{z}$ amerykańskiego gruntu należy świat społeczny małego miasta (middletown) R. S. Lynda oraz koncepcja Yankee City W. L. Warnera (73).

Poglądy F. Toenniesa na temat społeczności zostały zawarte $\mathrm{w}$ jego największym dziele "Wspólnota i stowarzyszenie". Uważa on, że społeczność, to lud zorganizowany jako odrębna, indywidualna jaźń, a zatem mogąca pozostawać w pewnym stosunku do swoich członków i organów. Społeczność jest instytucją prawa lokalnego, która w akcie przetwarzania samej siebie dochodzi do dziedziny prawa pozytywnego. Nie obyczaje tworzą społeczność lecz istnienie społeczności jest warunkiem powstania obyczajów. Istnieją 
następujące społeczności: społeczność patriarchalna, w której wspólne posiadanie ziemi już istnieje, ale jeszcze nie jest cechą istotną, społeczność miejska, w której wspólne posiadanie jeszcze występuje, ale już nie jest cechą istotną. Między społecznością a wspólnotą zachodzi stosunek taki jak między zwierzęciem a rośliną. Roślina jest czystszym, a zwierzę pełniejszym przejawem ogólnej idei istoty żywej. Podobnie wspólnota jest czystszym, a społeczność pełniejszym przejawem idei ciała społecznego. Jeśli społeczność jest jednostką terytorialną, składającą się z wielu posiadłości ziemskich, wsi i miast, albo konfederacją posiadłości ziemskich, to każda z tych części składowych, jeśli panuje nad swoim terytorium i zdolna jest do obrony własnych ziem, ma tendencje do przekształcania się w odrębną społeczność (74).

W odróżnieniu od literatury amerykańskiej w literaturze polskiej (jak stwierdza K. Komendera) pojęciu społeczności zwłaszcza łącznie z przymiotnikiem lokalna, nadaje się ściślejsze znaczenie, odnosząc je przede wszystkim do niewielkich liczebnie społeczności wiejskich i miejskich. Bardzo rozbudowaną liczebnie definicję społeczności lokalnej podał P. Kryczka - jest to zbiorowość składająca się z niewielkiej liczby osób zamieszkujących w bezpośredniej bliskości, pozostających w bezpośrednich, niesformalizowanych i osobistych kontaktach. Zbiorowość ta jest względnie odizolowana od pozostałego świata, a przez to samowystarczalna, autonomiczna, zdolna ze względu na szeroki zakres spełnianych funkcji do zamknięcia w swoich ramach życia społecznego człowieka, jest to zbiorowość homogeniczna majątkowo, zawodowo, etnicznie, w której szczególną rolę odgrywa sąsiedztwo i pokrewieństwo. Społeczność ta jest oparta na wspólnocie norm i tradycji, uznaniu autorytetów, posiadaniu wspólnych wartości, wierzeń, przekonań, a przez to jest solidarna wewnętrznie (współdziałanie, pomoc), i zdolna do sprawowania silnej kontroli wobec swoich członków. W artykule "Społeczność lokalna" J. Turowski przedstawił cztery koncepcje teoretyczne w podejściu do kwestii społeczności. Pierwsza z nich opierając się głównie na badaniach S. Nowaka, zakłada stopniowy zmierzch społeczności lokalnych, w wyniku rozrostu wielkich organizacji. Druga (teoria zaćmienia), zakłada, że społeczność nie zamiera jako efektywna grupa, ale zmienia swoją strukturę i funkcję dostosowując się do współczesnego rozwoju. Trzecią teorią jest teoria społeczności bezlokalnych. We współczesnym świecie społeczności podlegają daleko idącej specjalizacji. Czwarta koncepcja - transformacji społeczności zakłada, że industrializacja przekształca tradycyjne więzi i formy przynależności do społeczności, ale ich nie likwiduje. Znaczenie społeczności lokalnych przejawia się m.in. w pełnieniu przez nie istotnych funkcji społecznych: kształtują one osobowość człowieka, system wartości, wzory zachowań i poglądy oraz są terenem na którym dokonuje się przyswojenie statusowych ról przez członków grupy, przystosowują ludzi do życia w większych grupach, dostarczają człowiekowi pewnych szczególnych wartości: zadowolenia $\mathrm{z}$ bezpośrednich kontaktów, lokalnego uznania i dumy, których nie mogą zapewnić wielkie społeczności, wytwarzają formy i obrzędy ułatwiające przetrwanie krytycznych momentów, czy okresów życia (75).

$\mathrm{Z}$ aspektu teorii systemów, społeczności lokalne można rozpatrywać jako określone systemy społeczne, ponieważ mają one charakterystyczne dla nich właściwości: morfologia, struktura, hierarchia, zdolność adaptacji, swoisty układ funkcji i pozycji, układ wartości. Do najbardziej typowych społeczności lokalnych zaliczamy następujące: społeczności wiejskie, osad, dzielnic, małomiasteczkowe, miejskie, wielkomiejskie i regionalne. Specyfika każdej społeczności wynika z jej własnych doświadczeń nagromadzonych w procesie kształtowania się oraz procesie społecznego przystosowania się do danych warunków geofizycznych, a także ich osiągnięć w procesie humanizacji środowiska naturalnego (76). 
W rozważaniach społeczności lokalnych, których członkowie połączeni są albo kontaktami osobistymi, albo przynajmniej przekonaniem o możliwości takich kontaktów, doniosłość problematyki sąsiedztwa podkreślana była zwłaszcza przez badaczy anglosaskich. Postulowali oni najczęściej, by traktować stosunki sąsiedzkie jako wskaźnik odradzania się na terenie miasta nowej, zmienionej postaci społeczności lokalnych, lub przynajmniej niektórych jej funkcji. Współczesne sąsiedztwo przybiera różne formy np. sąsiedztwa utajonego, ukrywającego się pod postacią wzajemnej życzliwości mieszkańców. Obecne możliwości uzyskania własnego mieszkania, zwłaszcza czas oczekiwania na nie wpływają i nadal będą wpływać na poszerzenie się zjawiska wielopokoleniowych rodzin osiedlowych, przez co będzie się zmniejszać udział styczności i stosunków pozarodzinnych w całej sieci owych kontaktów (77).

Społeczność lokalna może obejmować całość aktywności życiowej człowieka, obejmując również strukturę jego osobowości, ukształtowanej poprzez procesy socjalizacji i wychowania, dokonujące się w ramach społeczności, oraz wspólny etos pracy. Wspólnota poza tym , że stała się kategorią socjologiczną, jest przede wszystkim kategorią normatywną, etyczną, jest wartością (różnie uzasadnianą), o którą należy zabiegać dla dobra człowieka. Społeczność jest przede wszystkim kategorią socjologiczną teoretyczną i empiryczną, umożliwiającą studia nad ważną postacią przestrzennie zorganizowanego życia zbiorowego (78).

Oficjalnie cały Kościół jest hierarchiczną społecznością, społecznością tworzącą jeden wspólny organizm, ciałem, w którym istnieje rozmaitość członków (79).

Przy naciskach władzy państwowej, można się dopatrzyć zagrożenia dla myślenia o Kościele w kategoriach wspólnoty. Kościół odnosi wtedy zwycięstwo, ale zamiera chrześcijaństwo. Odnosi zwycięstwo Kościół rozumiany jako społeczność, ale zanika ten rozumiany jako wspólnota. Opiera się to na rozważaniach jeszcze św. Augustyna w "Civitas Dei”, gdzie mówi się o Kościele, ale nie w kategoriach ziemskich. Mówi się natomiast o społeczności, w której tu na ziemi doskonalą się ludzie, chcąc osiągnąć wieczne szczęście (80).

Społeczność w szerokim sensie oznacza każdą formę trwałego stowarzyszenia między jednostkami, które wspólnie zmierzają do urzeczywistnienia jakiejś jednej wartości, czy celu. Tak pojmowana społeczność współgra pojęciowo ze wspólnotą (81).

Konsolidację społeczności religijnej osiąga się przez formułowanie wyznań wiary mających wyrażać pobudzać ludzi natchnionych podobnymi lub identycznymi doświadczeniami. Protest przeciwko tradycyjnym formom wyrazu religijnego nie musi wykluczać planów nowej społeczności religijnej, lub zapoczątkowania reorganizacji i reorientacji w ramach społeczności tradycyjnej. Trudności teoretyczne rozwiązuje się przez nawrót do początków religii, lub przez przystosowanie do filozofii współczesnej, a schematyczna koncepcja społeczności religijnej, może być nastawiona na związek (convenant), braterstwo (fellowship), albo stowarzyszenie (society), zamiast organizacji eklezjastycznej (82).

Społeczność wiernych obdarzona bogactwami kultury własnego narodu powinna głęboko zapuścić korzenie w lud, aby powstały rodziny głęboko przeniknięte duchem nauki Mistrza z Nazaretu (83).

Jako członek społeczeństwa i całej rodziny ludzkiej, każdy jest powołany do popierania w miarę możliwości rozwoju całej ludzkiej społeczności. Wiąże nas zatem solidarność przynaglająca do działania na rzecz postępu w skali globalnej, a ochrony środowiska w szczególności. Wychodząc natomiast poza krąg życia rodzinnego, ku społeczności państwowej, należałoby wysunąć na pierwsze miejsce wezwanie Kościoła do podejmowania 
najdalej idących wysiłków w kierunku usunięcia jakichkolwiek przejawów dyskryminacji rasowej, narodowej, religijnej, czy kulturowej (84).

\section{7. Spójność (spoistość) społeczna}

Pojęcie spoistości grup społecznych zostało skonstruowane przy użyciu wyrażenia określanego mianem "tele" w socjologii J. Moreno (85).

Sama definicja spoistości była jak na owe czasy tradycyjna. Moreno określał ją jako siłę utrzymującą jednostki w ugrupowaniach, w których się one znajdują. Spójność grupowa decyduje o przekroczeniu przez grupę poziomu przypadkowości. $Z$ grubsza rzecz biorąc spójność jest określana jako stopień w jakim grupa trzyma się razem jako całość. Jest to całościowe pole sił działających na członków w kierunku pozostania w grupie. Spójność jest też wynikiem oddziaływania na wszystkich członków grupy tych sił, które zmuszają do pozostawania w grupie. Spójność grupowa jest stosunkiem wewnątrzgrupowych wyborów socjometrycznych, do wyborów zewnątrzgrupowych. Jest to wzór atrakcyjności interpersonalnej. Reasumując: spójność grupy jest stanem jej wewnętrznej, szeroko rozumianej unifikacji. Jest ona własnością emergentną grupy, własnością globalną, istniejącą na poziomie grupy jako całości. Spójność jest czymś do czego grupa dąży, co jest potrzebne do jej istnienia. Spójność grupowa jest przy tym potężnym narzędziem w ręku ewentualnych manipulatorów. Jej siła polega na tym, że czyni grupę zdolną do bardzo dużego wysiłku, sprawności i poświęcenia, zdolną do całkowitego podporządkowania się, przy jednoczesnym wewnętrznym poczuciu wolności i satysfakcji. Gdy próg spójności grupowej zostanie przekroczony następuje proces deindywidualizacji jednostek, oraz następuje tzw. syndrom grupowego myślenia (86).

Umiarkowany wzrost konfliktu międzygrupowego nie powoduje wzrostu spoistości, natomiast gdy konflikt międzygrupowy przekroczy określoną wartość, spójność zaczyna szybko rosnąć. Jest to tzw. efekt akumulacyjny socjologicznej współzmienności. Istnieje pewien przedział wartości zmiennej (przyczyny), w którym nie wywiera ona zauważalnego wpływu na zmienną wyjaśnioną, poza tym przedziałem natomiast wpływ jest znaczny (87).

Spójność systemu przekonań jest rozumiana, jako zgodność akceptacji przekonań kościelnych, naturalnych i centralnych. Może ona sięgać nie tylko poziomu asercji, ale i jej źródeł akceptacji (88).

Spójność zależy w dużo większym stopniu od struktury nieformalnej, niż od struktury formalnej. Fundamentem spójności nie jest zewnętrzne przystosowanie się, formalne wypełnianie przepisów, ale głęboko zakorzenione w osobowości każdego członka poczucie przynależności. Grupa jest wtedy spójna, gdy:

- łączą ją wspólne wartości, normy, a przede wszystkim wspólny cel, który staje się celem poszczególnych jednostek,

- zaspokojone są potrzeby i oczekiwania członków,

- istnieją pozytywne postawy między członkami (wzajemna atrakcyjność),

- zaakceptowane są przez wszystkich role pełnione przez poszczególne osoby) wynikające ze struktury formalnej i nieformalnej),

- w ścisłym związku ze spójnością pozostaje tzw. duch grupy (89).

Na podstawie badań R. Mucchielli ustalił siedem czynników warunkujących dobrego ducha $\mathrm{w}$ grupie:

- dobre stosunki międzyosobowe, wzajemne zrozumienie, pomoc, zaufanie, mają one związek z satysfakcją członków, płynącą z osiągnięć grupy,

- dobre stosunki z osobami mającymi władzę, przejawia się w tym zaufanie do struktury formalnej grupy, 
- nadzieja na osiągnięcie celów grupowych, jest czynnikiem dynamizującym grupę, sprawiającym, że widzi ona swoją przyszłość,

- współpraca i aktywne uczestniczenie w życiu grupy, przejawia się to $\mathrm{m}$. in. w udziale w podejmowaniu decyzji dotyczących, bądź celów, bądź działań prowadzących do tych celów,

- odporność na naciski zewnętrzne, grupa stawia opór temu, co jej może zagrażać, wzmaga swoją solidarność i dążenie do autonomii,

- pogodna atmosfera wyraża zadowolenie członków z przynależności do grupy i jednocześnie wpływa na to, że grupa jest atrakcyjna,

- dojrzałość grupy i zdolność do refleksji, pozwala nie tylko zastanawiać się nad celami i środkami, brać udział w decyzjach, ale pozwala również przeciwstawiać się różnym pogłoskom i urojeniom grupowym, a po ewentualnym kryzysie, daje zdolność do odnalezienia równowagi (90).

Pojęcie spójności społecznej wiąże się nierozłącznie ze spoistością społeczną, która wg. E. Durkheima jest rezultatem procesu społecznego, wynikającego $\mathrm{z}$ oddziaływania sił społecznych na członków grupy. W Teorii G. Simmla spoistość zakłada konsolidację wewnętrzną jako formę uspołecznienia. Konflikt zewnętrzny wywołuje spoistość wewnętrzną, zwartość o charakterze bezpośrednim i osobistym. W najnowszej koncepcji C. Cooleya spoistość jest jednością wewnętrznie zróżnicowaną (91).

W opracowaniu J. Olbrychta jest więzią społeczną, jednością, solidarnością poczuciem "my", afiliacją, morale grupowym, atrakcyjnością grupy na zewnątrz i dla członków nawzajem. Więź społeczna implikuje spoistość, która może być mierzalna. Integracja jest procesem społecznym, zaś spoistość stanem określonej grupy społecznej. Do wskaźników spoistości zalicza wspomniany autor:

- postawy wobec grupy, motywacje uczestnictwa, stopień zaspokojenia potrzeb, poczucie przynależności do grupy,

- relacje interpersonalne,

- sieć interakcji, podobieństwo postaw (92).

\section{Przypisy do rozdziału III-go}

1. R. A. Nisbet: Conservatism and Sociology, w: American Journal of Sociology 58(2) (1952) 167-175.

2. J. Szacki: Historia myśli sociologicznej, Warszawa 1983, s. 163.

3. H. Saint - Simon: Organizator, w: Pisma wybrane t. 2, Warszawa 1968, s. 313-314.

4. K. Marks, F. Engels: Święta rodzina, Warszawa 1961, s. 148-149.

5. J. Szacki: op. cit., s. 307.

6. E. Durkheim: Les formes elementaires de la vie religieuse, Paris 1960, s. 553.

7. J. Szacki: op. cit., s. 502.

8. G. Simmel: Socjologia, Warszawa 1975, s. 12.

9. J. Szacki: op. cit., s. 551.

10. S. Ossowski: Więź społeczna i dziedzictwo krwi, Warszawa 1966, s. 145-53.

11. J. Szmatka: Małe struktury społeczne, Warszawa 1989, s. 58-104. 
12. Z. Freud: Psychologia zbiorowości i analiza ego, Warszawa 1975, s. 339.

13. J. Majka: Filozofia społeczna, Wrocław 1982, s. 337-339.

14. S. Olejnik: Teologia moralna, Warszawa 1991, s. 271.

15. S. Ossowski: O ojczyźnie i narodzie, Warszawa 1984, s. 62.

16. A. Borowski: Więź społeczna w parafii, potrzeba budowania jedności, Szczecin1992, s. 14.

17. P. Rybicki: Społeczeństwo miejskie, Warszawa 1972, s. 382-384.

18. Ibidem: s. 676-677.

19. E. Ciupak: Religijność młodego Polaka, Warszawa 1984, s. 70-71.

20. G. W. Stocking: Culture and Evolution, New York 1968, s. 214.

21. E. Hatch: Theories of Man and Culture, New York 1973, s. 76-77.

22. A. L. Kroeber: Istota kultury, Warszawa 1973, s. 115.

E. Sapir: Kultura, język, osobowość, Warszawa 1978, s. 142-143.

23. F. Znaniecki: Nauki o kulturze, Warszawa 1971, s. 680.

24. T. Parsons: Societies, New York 1966, s. 22-23.

25. L. A. Coser: The Functions of Social Conflict, New York 1964, s. 8-9.

26. A. Paluch: Mistrzowie antropologii społecznej, Warszawa 1990, s. 210.

27. P. Blau: Echange and Powein Social Life, New York 1964, s. 13.

28. S. Rychliński: Ujęcie więzi społecznej w socjologii L. Krzywickiego, Warszawa 1938, s. 153-194.

29. W. S. Landecker: Types of Integration and their Measurement, New York 1962, s. 19-27.

30. J. Walkowiak: Przystosowanie młodzieży, a integracja społeczna, Szczecin 1987, s. 5-10.

31. M. Ossowska: Normy moralne, Warszawa 1970, s. 173.

32. J. Szczepański: Przystosowanie młodzieży do studiów wyższych, w: Kultura i społeczeństwo, 1/1962.

33. M. Hirszowicz: Wstęp do socjologii organizacji, Warszawa 1967.

34. J. Walkowiak: op. cit., s. 10-17.

35. W. Jacher: Kategoria integracji społecznej, w: Studia Sociologica, Szczecin 1992, s. 25-27.

36. J. Pająk: Zakład pracy w systemie integracji społecznej, w: Studia ..., op. cit., s. 145-149.

37. J. Höffner: Chrześcijańska nauka społeczna, Kraków 1989, s. 133.

38. J. Szmatka: Małe ... op. cit., s. 41. 
39. B. Chmielewska: Kilka refleksji na temat więzi lokalnych i regionalnych, w: Roczniki Koszalińskie 1975, s. 26.

40. S. Olejnik: Teologia moralna, Warszawa 1991, s. 271

41. M. Miazga: Kształtowanie się społeczności w mieście o szybkim rozwoju, Studia Socjologiczne XXXV (1985) 170.

42. W. Durka: Statystyczne wskaźniki integracji, Roczniki socjologii morskiej 6 (1991) 81-83.

43. J. M. Yinger: Religia jako czynnik integracji społecznej, w: Socjologia religii (red. F. Adamski) Kraków 1984, s. 130-138.

44. H. Łuczak: Wspólnota zbawienia, Warszawa 1990, s. 70-72.

45. J. Szmatka: Małe ... op. cit., s. 348-350.

46. F. Kampka: Zasada solidarności, a związki zawodowe, w: Ethos 11-12/1990, s. 78-79.

47. M. Brzozowski: Solidarność, to imię społecznej miłości, w: Ethos 11-12/1990 r., s. $158-160$.

48. Jan Paweł II: Przemówienie do ludzi morza, Gdynia 11.06.1987, w: Znak 1-2/87, s. 96-98.

49. J. Szacki: Historia ... op. cit., s. 426-430.

50. S. Olejnik: Teologia ... op. cit., s. 271.

51. Gaudium et Spes, w: Sobór Watykański II (dokumenty), Poznań 1986, s. 560-561.

52. J. Warzeszak (red): Rozważania dla instytutów świeckich, Warszawa 1990, s. 124.

53. J. Wach: Socjologia religii, Warszawa 1961, s. 148-152.

54. J. Höffner: Chrześcijańska ... op. cit., s. 29-30.

55. K. Wojtyła: U podstaw odnowy, Kraków 1988, s. 231-245.

56. J. Höffner: op. cit., s. 243.

57. T. Żeleźnik: Człowiek w Kościele i świecie, w: Kościół, świat,świeccy, Warszawa 1988, s. 147.

58. J. Ratzinger: Prymat Piotra, a jedność Kościoła, w: Communio, 6/91, s. 15.

59. M. Żurowski: Współuczestnictwo kościelne, Kraków 1984, s. 18-23.

60. F. Blachnicki: Kościół jako wspólnota, Lublin 1981, s. 101.

61. J. Ratzinger: List do biskupów kościoła katolickiego, Krościenko 1993, s. 11-12.

62. C. Lubich: Klucz do jedności, Poznań 1989, s. 307-320.

63. Lumen Gentium, w: Sobór Watykański op. cit., s. 119.

64. F. Capra: Jedność wszystkich rzeczy, w: Nomos 1/92, s. 23-24. 
65. A. Hartliński (red): Nauka Soboru Watykańskiego II, Poznań 1986, s. 20.

66. E. Ozorowski: Kościół, Wrocław 1984, s. 71-200.

67. J. Szacki: Historia ... op. cit., s. 45-667.

68. A. P. Hare: Wielkość grupy a consensus, w: Elementy mikrosocjologii, cz. 2 (red. J. Szmatka) Kraków 1992, s. 228-235.

69. Arystoteles: Polityka, Warszawa 1969, w: 1326 b.

70. O. Gierke: Natural Law and the Theory of Society, Boston 1957, s. 71.

71. C. Cooley: Social Organization, New York 1964, s. 23.

72. G. A. Hillery: Deffinitions of Community, w: Rural Sociology, t. 20/55, s. 111-119.

73. J. Szacki: Historia ... op. cit., s. 44-700.

74. F. Toennies: Wspólnota i stowarzyszenie, Warszawa 1988, s. 291-297.

75. A. Śliwińska: Wychowawcze aspekty społeczności lokalnych, w: Socjologia wychowania t. IX, Toruń 1990, s. 51-60.

76. J. Sztumski: Społeczności lokalne jako przedmiot badań socjologicznych, w: Społeczności lokalne regionu Górnego Śląska, Katowice 1987, s. 5-14.

77. A. Sosnowski: Rodzina, a sąsiedztwo w osiedlowych społecznościach lokalnych, w: Morskie społeczności lokalne, teoria i empiria, Szczecin 1991, s. 143-167.

78. W. Świątkiewicz: Miejskie społeczności lokalne Górnego Śląska, w: Tożsamość kulturowa mieszkańców dzielnic miast Górnego Śląska, Katowice 1991, s. 67-69.

79. E. Ozorowski: Kościół, op. cit., s. 67.

80. E. Staniek: Kościół, bogactwo tajemnicy, Kraków 1990, s. 12-13.

81. J. Höffher: Chrześcijańska ... op. cit., s. 23-24.

82. J. Wach: Socjologia ... op. cit., s. 64-175.

83. Ad gentes divinitus, w: Dokumenty Soboru ... op. cit., s. 451.

84. S. Olejnik: Teologia ... op. cit., s. 234-252.

85. J. Moreno: Note on Cohesion in Social Groups, w: Sociometry 13/1951, s. 176.

86. J. Szmatka: Małe ... op. cit., s. 143-248.

87. P. Abell: Modele w socjologii, Warszawa 1975, s. 201.

88. W. Chaim: Psychologiczne analizy religijności niespójnej, Lublin 1991, s. 94-96.

89. J. Słomińska: Mechanizmy i funkcje grup młodzieżowych, Warszawa 1986, s. 14-16.

90. R. Mucchielli: La dynamique des groupes, Paris 1976, s. 46-61.

91. J. Olbrycht: Spoistość małej grupy społecznej, Katowice 1987, s. 21-35.

92. Ibidem, s. 35-67. 


\section{METODY I TECHNIKI POSTEPOWANIA BADAWCZEGO}

Przed przystąpieniem do badań, które przeprowadzono metodą obserwacji uczestniczącej, należało uściślić terminologię, która została użyta przy opracowywaniu wyników (1).

Na rozważenie zasługuje zwłaszcza kwestia wieloznaczności języka socjologicznego. Opracowanie słownika terminów socjologicznych znacznie ułatwiłoby korzystanie $\mathrm{z}$ piśmiennictwa obcego oraz ujednolicenie terminologii stosowanej w przekładach. Sprawa oczywiście nie sprowadza się do mniej lub bardziej typowych zagadnień i dylematów warsztatu tłumacza. Najistotniejszy wydaje się fakt powiązania tej problematyki z szeroką i ważną dziedziną rozumienia, często nazywaną (także w słownikach) jako "Verstehen", ze względu na udział W. Diltheya i M. Webera oraz innych uczonych niemieckich w nurcie, który problematykę tę w podobnej formie podjął (2).

Operacja zwana rozumieniem polega na:

- zaobserwowaniu zjawisk, zachowań, bodźców oraz reakcji na nie,

- postulowanie, iż obok tych zmiennych obserwowalnych, występują zjawiska dla nas nieobserwowalne, ale w swych treściowych i racjonalnych aspektach dostępne,

- orzekanie, że między zjawiskami obserwowanymi, a desygnatami hipotetycznymi zachodzą związki takie, iż desygnaty te są zmienną zależną, niezależną lub pośredniczącą (3).

Do szczególnie doniosłych dla socjologii w ogóle, także w aspekcie opracowywania słownika terminów, należą te poszukiwania (prowadzone z myślą o opracowaniu narzędzia analizy), w których próbuje się pojęcia o znaczeniu niejasnym zoperacjonalizować. Przykładem może być dokonana przez S. Ossowskiego analiza pojęcia więzi społecznej. Zawarte są $\mathrm{w}$ niej psychologiczne kategorie identyfikacji i behawioralna kategoria współdziałania (4).

W tej pracy używane jest często słowo "kategoria". Pojęcie i termin kategoria znaczeniowa wprowadził pierwszy E. Husserl. W swoim dziele "Logische Untersuchungen" zauważa, że można podzielić pojedyncze wyrazy i złożone wyrażenia języka na takie klasy, że dwa należące do tej samej klasy wyrazy, czy wyrażenia mogą się wzajemnie zastępować w kontekście posiadającym jednolite znaczenie, przy czym zmieniony kontekst nie staje się przez to jakimś zestawieniem niepowiązanych słów, ani w ogóle nie traci jednolitego znaczenia, podczas, gdy dwa słowa, czy wyrażenia należące do różnych klas tej własności nie posiadają (5).

Drabina kategorii znaczeniowych jest blisko spokrewniona $\mathrm{z}$ uproszczoną hierarchia typów logicznych i w gruncie rzeczy tworzy jej gramatyczno - semantyczny odpowiednik (6).

Wśród wszystkich kategorii znaczeniowych można wyróżnić dwa rodzaje, które nazwiemy kategoriami podstawowymi i funktorowymi. Kategorie funktorowe, to te kategorie znaczeniowe, do których należą funktory (znaki funkcyjne), tzn. takie, przy których są nawiasy. Kategorie podstawowe, to takie, które nie są kategoriami funktorowymi (7).

E. Husserl kategorie semantyczne określał z aspektu składni. Nazwy jednostkowe i zdania,. to dwie pierwsze kategorie semantyczne. Dalsze kategorie semantyczne można znaleźć wśród wyrażeń języka, które denotują funkcje i które nazywamy znakami funkcyjnymi (funktorami) (8).

Bogactwo kategorii semantycznych mowy potocznej, nie jest dość stanowczo ustalone. W szczególności chodzi o to, że można podać klasę wyrażeń mowy potocznej, co do których 
trudno jest orzec, czy wszystkie wyrażenia należą do tej samej kategorii semantycznej, czy też rozpadają się na kilka takich kategorii. Klasą taką jest np. nazw tzw. mowy potocznej (9).

Kategorią jest zbiór elementów nie posiadających struktury, a więc w ogóle nie związanych stosunkami danego rodzaju (10).

Kategorią socjologiczną wspólnoty jest coś więcej niż stereotyp (typowe wyobrażenie o poszczególnych desygnatach danej nazwy) (11).

"Naiwny" badacz wtapia w obraz wspólnoty całą swoją ogólną wiedzę o niej i jej społecznym tle, nawleka obraz wspólnoty na nici porównań z obrazami wielu innych grup, wplata go w rozległą sieć społecznych kategoryzacji. Nic więc dziwnego, że słyszymy często wyraz "wspólnota", w ujęciu mowy potocznej, czyli takiej, według której wspólnotą może zostać każda grupa wyodrębniana jako osobna kategoria na tle społecznym i postrzegana jako osobna całość.Pojęcia w świetle teorii klasycznej wyliczają konieczne i wystarczające warunki, dzięki którym jednoznacznie określana jest przynależność do danej kategorii. Warunki te są wspólne dla wszystkich przypadków użycia danej nazwy. Żaden przypadek nie może być bardziej centralny, czy peryferyjny. J. Trzebiński używa pojęcia kategorii w ujęciu klasycznym nazywając je pojęciami matrycowymi, dlatego, iż układ koniecznych i wystarczających warunków działa jak matryca odciskająca dokładnie ten sam wzór, stanowi więc o jednorodności kategorii, o tym, że wszystkie jej desygnaty są traktowane jednakowo (12).

Rola terminów i stopnia ich precyzji w życiu człowieka lub wspólnoty ludzkiej jest zależna od poziomu rozwojowego (specjalizacyjnego) jaką osoba osiągnęła. Rola jest tym większa, im wyższy poziom rozwoju. W każdej wspólnocie (zwłaszcza większej) dolegliwości terminologiczne odczuwają przede wszystkim te, spośród tworzących je osób, ci jej członkowie, lub wspólnoty cząstkowe, które zajmują się bądź intelektualnym odwzorowywaniem, czy rekonstruowaniem świata, bądź jego praktycznym przetwarzaniem. Terminy bowiem determinują nie tylko ludzką sprawność komunikacyjną. W gruncie rzeczy warunkują one także (a może przede wszystkim), ludzką sprawność kognitywną oraz produkcyjną. Podobnie jak wiele ludzkich tworów, wspierają one także człowieka i zarazem stwarzają mu kłopoty (13).

Każde zachowanie religijne ma naturę i strukturę wspólnotową. Nie ma takiego, które artykułowałoby się poza nią. Religia jest wyjątkowym sposobem bycia i budowy wspólnotowej natury osoby oraz osobowej natury wspólnoty ludzkiej, świata społecznego w ogólności. Religijność danej wspólnoty religijnej jest szczególnym systemem interpretacyjnym siebie samej. Brak religijności w kulturze danej społeczności nie oznacza, że ta nieobecność nie jest nieobecnością fundamentalną, jest raczej swoistym milczeniem, co nie oznacza zaniemówienia (14).

Na jednostkę mogą oddziaływać abstrakty społeczne (rozmaite elementy massmediów), grupy społeczne i jednostki. Jednostka może być celem ostatecznym oddziaływania, ale może być również elementem pośrednim wpływania na inne jednostki lub inne grupy społeczne. Podobnie dzieje się z grupą społeczną. Może być ona ostatecznym celem oddziaływania, może być również środkiem oddziaływania na innych. Jednostka może być podmiotem inicjującym oddziaływania, może też być strategiem pierwotnym (15).

Integracja grupowa jest średnią wypadkową (lub sumą) sił, które skłaniają jednostkę do pozostania w grupie. Oznacza także zjawisko atrakcyjności grupy (attraction to the group) dla jej członków, bądź też zjawisko przychylnego reagowania jednostek na cechy grupy (16).

Im większa integracja grupy, tym większy konformizm wobec norm grupowych (17).

Zakres stosowalności metod statystycznych w socjologii grup jest, mówiąc najostrożniej, nikły. Analiza może nas zawsze poinformować w jakimś konkretnym 
przypadku, co do stopnia skorelowania zjawisk, lecz nie może służyć jako punkt wyjścia do rozważań ogólnych (teoretycznych) (18).

Umiarkowany wzrost konfliktu społecznego powoduje zmiany stopnia spójności grupowej (jest on bardzo słaby). Tolerujemy pewne elementy naszego środowiska społecznego, dopóki nie są one zbyt intensywne. Dopiero poza pewnym punktem krytycznym czujemy potrzebę “żeby coś z tym zrobić” (19).

Socjolog, zwłaszcza socjolog religii staje przed złożonym zadaniem (paradoksem metodologicznym). $Z$ jednej strony bowiem religia, jako zjawisko społeczne, jest ze względu na zakres treściowy definiendum trudno jednoznacznie definiowalna, $\mathrm{z}$ drugiej zaś strony mały rygoryzm metodologiczny dopuszczał analizy na poziomie potocznego (intuicyjnego) jej rozumienia. W badaniach socjologicznych, stosując typowe techniki, często trudno jest wydobyć subiektywne, niepowtarzalne aspekty religijności prywatnej. Religia jest systemem wierzeń opartym na dualistycznym rozróżnieniu na rzeczywistość empiryczną i transcendentną. Choć sam nie poddaje się on racjonalnej weryfikacji, to wyjaśnia w sposób możliwy do przyjęcia to, co w inny sposób wytłumaczyć się nie da. Odpowiadają tym wierzeniom symbole i formy zachowań kultowych, zbiór wartości i norm moralnych odwołujący się do autorytetu Boga i Kościoła, określający wzór osobowy człowieka religijnego oraz organizacja kościelna jednocząca wyznawców we wspólnotę. W praktyce badawczej często można spotkać się z religijnością selektywną, która przyjmuje jedną z trzech postaci: akceptacja wierzeń, przy odrzucaniu praktyk i autorytetu Kościoła, bezrefleksyjne spełnianie praktyk, przy obojętnym stosunku do wierzeń i instytucji Kościoła, odrzucenie wierzeń oraz praktyk, lecz uznanie religii za źródło norm moralnych, a Kościoła za instytucję je przekazującą (20).

Religia jak szereg innych zjawisk dopuszcza, przy podejmowaniu jej analizy, przynajmniej dwa różne typy ujęć: statyczne i dynamiczne. Ujęcie statyczne (bezczasowe, przekrojowe) polega na badaniu cechy, którą dostrzegamy u pojedynczego człowieka, czy w innej grupie, bez uwzględnienia, jak długo trwało posiadanie tej cechy, jakim podlegała ona zmianom, w jakie zdarzenia czy procesy uwikłany był jej nosiciel. Przeciwieństwem takiego ujęcia jest podejście dynamiczne. Obejmuje ono trwanie pewnych wartości lub stanów zbiorowości oraz zmiany jakim podlegają one na przestrzeni krótszych lub dłuższych odcinków czasu. W sekwencji zdarzeń o charakterze procesu powinna nastąpić pewna dominanta, pozwalająca na określenie skrótowo jego kierunku lub rezultatów. Osobne podejście stanowi natomiast analiza przemian, jakim podlega religijność pojedynczego człowieka, pod wpływem odkrywania dla siebie nowych aspektów przyswojonej uprzednio tradycji religijnej (21).

Istnieje przekonywująca liczba danych, dowodząca, że ludzka wiedza zorganizowana jest w pewną hierarchiczną strukturę, i że na pewnym jej piętrze zorganizowania pojawiają się takie elementy, które tradycyjnie zaliczamy do filozofii, religii, światopoglądu. Naturalną tendencją umysłu człowieka jest zaprowadzenie w poznawczej reprezentacji świata - ładu. Często przybiera on postać sensu naczelnego, porządkującego cały obszar doświadczeń życiowych jednostki. Takimi kategoriami porządkującymi są m.in. Bóg, los, szczęście, przeznaczenie, logika świata, sens historii, dobro ludzkości (22).

Ważny dział badań socjologicznych nad religijnością stanowią te badania, które koncentrują się na badaniu różnych wspólnot i instytucji religijnych. Przy badaniach najczęściej obiektem staje się rodzina, parafia, Kościół jako instytucja, kapłaństwo i wspólnoty zakonne oraz ruchy i wspólnoty religijne (23).

W swoich badaniach socjologowie posługują się różnymi metodami. Należy przy tym odróżnić metody i techniki zbierania danych, opracowywania danych oraz ich interpretacji. 
Zakres sposobów postępowania badawczego w socjologii jest zróżnicowany i prowadzenie badań socjologicznych wymaga precyzyjnego przestrzegania reguł, gdyż uczestnictwo i znajomość życia społecznego z jednej strony mogą być bardzo pomocne, ale z drugiej strony są źródłem uprzedzeń, uproszczeń i zniekształceń w opisie i interpretacjach faktów (24).

Współczesna socjologia (w tym polska) przeżywa od pewnego czasu odchodzenie od bezrefleksyjnego stosowania $\mathrm{w}$ badaniach empirycznych metod statystycznych. Pozwalały one stosunkowo szybko nagromadzić dużo danych, ułatwiały ich standaryzację, oraz mechaniczne obliczanie i niejednokrotnie powierzchowną tylko analizę. Rozpowszechnienie się badań ankietowych opartych na skategoryzowanych kwestionariuszach, ugruntował przekonanie, że są to najsłuszniejsze metody. Tych nowych standaryzowanych metod zbierania danych próbowano używać do badań takich zjawisk i faktów społecznych, które ze swej istoty nie były poznawalne i nigdy nie mogły być dogłębnie wyjaśnione za ich pomocą. Za jedną z najstarszych metod używanych w socjologii uważa się obserwację (zwłaszcza uczestniczącą). Za jej "ojców” w literaturze przedmiotu uchodzą J. Valdour i Ch. Booth, którzy przez wspólną pracę i zamieszkanie z ludnością będącą przedmiotem badań opracowali naukowe podstawy tej metody (25).

Termin obserwacja określić należy najrozmaitsze, po części całkowicie różne, sposoby gromadzenia danych. Należy do nich zarówno obserwacja uczestnicząca, którą posługuje się np. antropologia społeczna i kulturowa, etnologia oraz badacze pierwotnych systemów społeczno - kulturowych. Obserwacja uczestnicząca zdaje też egzamin w badaniach z zakresu socjologii religii, zwłaszcza, gdy dotyczą one formowania się postaw wiernych i budowania wśród nich więzi religijnej i społecznej. Obserwacja nieuczestnicząca służy badaniom zachowań grupowych $\mathrm{w}$ warunkach kontrolowanych. Jakkolwiek metody te różnią się w szczegółach, zawsze dotyczą one konkretnych zachowań, działań, interakcji symbolicznych, w różnych sytuacjach społecznych, bez względu na to, czy sytuacje te zostają umyślnie spowodowane dla celów eksperymentalnych, czy powstają spontanicznie w warunkach naturalnych. Przedmiotem obserwacji jest więc zachowanie, które ma określony sens subiektywny, a zarazem obiektywne znaczenie społeczne. Obserwacja wymaga rozumienia i trafnej interpretacji subiektywnego sensu oraz społecznego znaczenia określonego zachowania, czy działania. Bez takiego rozumienia, obserwacja staje się jałowa, a nawet bezprzedmiotowa. Miarą umiejętności rozumienia są zdolności obserwatora do antycypowania zachowań ludzi w obserwowanej sytuacji, a więc działanie w ten sam sposób, jak działają członkowie obserwowanego systemu społeczno - kulturowego, znający zinstytucjonalizowane oczekiwania społeczne. Obserwacja w socjologii musi opierać się na ogólnym modelu zachowania społecznego, ujmującym wymiary i determinanty tego zachowania na tyle jednoznacznie, by mogły pełnić rolę kategorii porządkujących obserwację. Metoda obserwacji, jaką należy w konkretnym przypadku zastosować zależy od zamierzeń badawczych. Mogą być one trojakie:

- celem może być wyłącznie opis występujących w określonym systemie społecznym i kulturowym zachowań oraz form interakcji społecznej, bez próby formułowania uogólnień teoretycznych,

- badania mogą służyć analizie zależności empirycznych między określonymi sekwencjami zachowań, warunkami sytuacyjnymi,

- ambicją badaczy może być nie tylko opis zachowań w określonym systemie społeczno kulturowym, lecz także ich teoretyczne wyjaśnienie, poprzez ukazanie przesłanek oraz obiektywnych następstw tychże zachowań. 
Posługiwanie się metodą obserwacji oprócz omawianych problemów teoretycznych wymaga także decyzji o charakterze metodyczno - technicznym. Od możliwości badania i jego celów należy wybór metody obserwacji. Metody te mogą być różne pod następującymi względami:

- obserwacja systematyczna i niesystematyczna,

- obserwacja w warunkach naturalnych i sztucznych,

- obserwacja uczestnicząca i nieuczestnicząca (26).

Prowadząc badania metodą obserwacji uczestniczącej, często emocjonalnie wykonując powierzoną rolę $\mathrm{w}$ badanej grupie narażamy się jako obserwatorzy na niebezpieczeństwo związane z tym mianowicie: Terminy emocjonalnie zabarwione, nie posiadające wyraźnej treści opisowej, zostają zawłaszczone do nauki, przy zachowaniu całej ich treściowej niejasności i zakresowej nieostrości. W wyniku tego bywają potem stosowane do formułowania twierdzeń empirycznych, mających jedynie pozory twierdzeń, gdy w gruncie rzeczy twierdzenia te wyrażają jedynie pozory twierdzeń naukowych, pewne wartościowania, emocje i oceny badacza posługującego się danym terminem (27).

Najważniejszym obecnie powodem unikania przez naukowców metody obserwacji uczestniczącej jest najprawdopodobniej ich niechęć do bezpośredniego, dość długiego kontaktu z jednym środowiskiem. Podłoże tej niechęci może być wielowymiarowe. $Z$ jednej strony może się nań składać niewiara we własne umiejętności, z drugiej może nimi powodować fakt strachu przed ujawnieniem przez członków badanej grupy ich faktycznej roli (jako obiektu badań), a co gorsza przypisanie obserwatorowi roli niezgodnej $\mathrm{z}$ rolą rzeczywistą. Badacz - obserwator powinien wcześniej określić fakty społeczne oraz społeczne znaczenie środków ekspresji, czyli inaczej sposobów współoddziaływania danych obiektów na siebie. Właśnie w takim rozumieniu można mówić, że dogłębne poznanie i ustalenie oraz zrozumienie społecznych zachowań jest konieczne dla ustalenia faktów społecznych (28).

Nauka rozpoczyna się od obserwacji i musi do niej powrócić, celem swego dalszego i ostatecznego sprawdzenia. Jeżeli badacz będzie dobrym obserwatorem, łatwiej mu będzie stawiać i kontrolować hipotezy i wnioski. Najlepszym sposobem gromadzenia materiału z obserwacji, jest prowadzenie arkusza lub dzienniczka obserwacji. warunkami poprawnie przeprowadzonej obserwacji są:

- wstępna, dobra znajomość przedmiotu obserwacji,

- szczegółowe poznanie przedmiotu obserwacji, poprzez stosowanie najbardziej standaryzowanych metod działania,

- bliższe sformułowanie badanego zagadnienia i celów obserwacji,

- szczegółowe opracowanie koncepcji badań, klasyfikacja zagadnień, opracowanie odpowiednich arkuszy obserwacyjnych. Sama obserwacja powinna być planowa, systematyczna i dokładna (29).

W związku ze zróżnicowaniem się informacji nabytych w wyniku obserwacji, traktuje się je jako mniej lub bardziej wiarygodne. Tworzy się przez to hipotetyczne kontinuum wiarygodności: od informacji na wysokim, do informacji na niskim poziomie wiarygodności (30).

W badaniach z zakresu socjologii religii, formy wspólnot stanowią aspekt obiektywny $\mathrm{i}$ one stają się przedmiotem badań socjologicznych (31).

Metoda obserwacji uczestniczącej $\mathrm{w}$ badaniach socjoreligijnych jest jak najbardziej potrzebna i efektywna. Pozwala ona na głębsze zrozumienie ludzkich postaw wobec Kościoła, religii i wspólnoty religijnej. Aby zrozumieć motywację jaką kierują się osoby 
biorące udział w życiu konkretnej wspólnoty, należy przeprowadzić obserwację uczestniczącą. Gdyby badania przeprowadzone były inną metodą, istnieje niebezpieczeństwo udzielania odpowiedzi wymijających lub niepełnych. Jest to przecież jedna z najgłębszych sfer ludzkiej osobowości i nie każdy człowiek jest w stanie dzielić się swoimi przeżyciami w tym względzie $\mathrm{z}$ obcą osobą. Budowaniu wzajemnego zaufania może natomiast służyć spełnianie podobnych ról w obrębie badanego zjawiska, czy grupy wspólnoty. Oczywiście metoda ta ma też swoje negatywne strony, zwłaszcza, gdy badacz do tego stopnia zintegruje się z badanym środowiskiem, że zatraci potrzebny do przeprowadzenia obiektywnych badań dystans (intersubiektywną kontrolowalność). Istnieją $\mathrm{w}$ rzeczywistości badanej takie środowiska, do których wejście, nie mówiąc już o podjęciu badań socjologicznych nie jest możliwe, bez podjęcia ról właściwych danemu środowisku. Jednym z takich środowisk jest Ruch "Światło - Życie" i jego wspólnoty w parafiach. Do przeprowadzania badań najlepiej jest występować w roli animatora, czyli osoby mającej bezpośredni kontakt z uczestnikami i innymi animatorami. Plusem jest też szeroki dostęp do publikowanych materiałów, proponowanych przez centralę tego Ruchu. Minusem opisywanego podejścia jest fakt, że aby zostać animatorem należy przejść co najmniej 3 - letni program formacyjny, połączony z kursem dla animatorów. Dla badacza wiąże się to z potrzebą wcześniejszego nawiązania i utrzymywania kontaktów $\mathrm{z}$ badaną wspólnotą z tego też powodu niezmiernie rzadko zdarzają się przypadki tak długiego pozostawania badacza w obserwowanym środowisku. Dłuższe przebywanie pozwala na poznanie głębszych motywacji uczestnictwa i aktywności poszczególnych członków wspólnoty. Podczas badań metodą obserwacji uczestniczącej można też na bieżąco zauważać zmiany w sposobie zachowania, jako wynik formacji w danej wspólnocie (konwersja). Badacz będąc w pozycji animatora ma także wpływ na kształtowanie obrazu danej wspólnoty (32).

Metoda obserwacji uczestniczącej jest jedną z metod jakościowych. Technika ankiety, czy wywiadu dostarcza materiałów, co do wiarygodności których można mieć zawsze większe lub mniejsze wątpliwości. Zastrzeżenia te wzrastają, zwłaszcza gdy wywiad prowadzi osoba z zewnątrz (dla respondenta). Stosując nawet najbardziej anonimową ankietę, nie możemy zapewnić respondentom $100 \%$ anonimowości. Wielu badanych ma tego mniejszą lub większą świadomość, stąd często w badaniach przeprowadzanych techniką ankiety, przez osobę z zewnątrz, odpowiedzi są nieszczere, sztampowe i jałowe. Może się to zdarzyć, że od tych samych osób otrzymamy dwie różne odpowiedzi, na jedno pytanie, w różnym czasie. Jest to wtedy spowodowane brakiem głębszej refleksji przy odpowiadaniu na pytania kwestionariusza, ale także wieloma obiektywnymi i subiektywnymi uwarunkowaniami, jakie spotykają danego respondenta. Wiedza zbierana metodą obserwacji ma jedną ważką zaletę, w porównaniu do badań surveyowych. Autentycznie dotyczy ona bowiem świata i rzeczywistości, w której są prowadzone badania, nie ma w niej miejsca na mniemanologię i przeinaczanie. Niezwykle ważną przesłanką przemawiającą za $\mathrm{w}$ miarę szerokim stosowaniem tej metody jest sytuacja ekonomiczna i stale malejąca liczba środków przeznaczonych na oświatę, a co za tym idzie, na prowadzenie badań naukowych. Prowadzenie badań socjoreligijnych będzie najbardziej adekwatne do rzeczywistości, jeśli zastosujemy obserwację uczestniczącą. Nie zamykam przez to możliwości posiłkowego korzystania $z$ innych metod zbierania danych. Należy jednak pamiętać, iż przy przeprowadzaniu tego typu badań należy utrzymywać bliski kontakt z respondentami. Przy prowadzeniu badań socjoreligijnych, posiadając wspólną płaszczyznę emocjonalną $\mathrm{z}$ respondentem, możemy posłużyć się metodą wywiadu (33).

Wywiad jest rozmową $\mathrm{z}$ respondentem według wcześniej opracowanych przez badacza dyspozycji, mających na celu wydobycie informacji - którą posiada respondent. Połączenie 
metody obserwacji uczestniczącej i wywiadu pozwala na weryfikację udzielanych odpowiedzi przez dane uzyskane w ramach drugiej osoby (34).

$\mathrm{W}$ badaniach socjoreligijnych bywa też stosowany szereg metod $\mathrm{z}$ dziedziny psychologii. Przykładem może być:

- Inwentarz Życia Religijnego (C. D. Batsona) służący mierzeniu orientacji religijnej i światopoglądowej,

- Inwentarz Życia Wewnętrznego (P. Sochy i A. Latały): do badania orientacji światopoglądowych,

- Skala Postaw SIR (Likerta), wskaźnik religijnej ortodoksji,

- Skala Religijności Chrześcijańskiej (P. Sochy), wskaźnik postawy wobec religii,

- deklaracja przemian religijności - wskaźnik przemian jej dynamiki,

- Skala Zależności Emocjonalnej (M. Jasieckiego) - wskaźnik występowania, lub braku emocjonalnej zależności (35).

Szczególną cechą religijności jest jej dynamiczny charakter. Częściowy pomiar tej cechy umożliwia pytanie, które skategoryzowane jest, jako postrzeganie zmian religijności przez badanego (w kierunku większej lub mniejszej religijności, kryzysu religijnego lub braku zmian) (36).

Socjologia religii nie może być oderwana od socjologii ogólnej, z której zapożycza swoje koncepcje. Przy analizie zjawisk religijnych w obecnym okresie wysuwa się zwłaszcza studium nad stopniem przynależności parafian do różnych instytucji parafialnych, także ruchów i organizacji, w ramach realizacji soborowej wizji parafii jako wspólnoty wspólnot.

$\mathrm{Na}$ podstawie powyższych ustaleń sformułowano problem badawczy, który brzmi następująco: Na ile wspólnoty ruchów odnowy realizują zadanie jednoczenia społeczności w znaczeniu "mikro" i "makro" tworząc społeczność "mezo" (wspólnotę).

Badania empiryczne miały także udzielić odpowiedzi na następujące zagadnienia szczegółowe:

1. Jak funkcjonuje Ruch "Światło - Życie" jako makrostruktura społeczna ?

2. Funkcjonowanie wspólnot parafialnych Ruchu jako mezostruktury społecznej.

3. Małe grupy formacyjne i diakonijne jako mikrostruktury społeczne.

4. Przenoszenie wzorców zachowań i wzajemnych stosunków ze wspólnoty Ruchu do życia codziennego (życie charyzmatami Ruchu).

5. Czy konwersja jest podstawą budowania wspólnoty?

6. Jak wygląda realizacja zasady równości i jednoosobowego kierownictwa we wspólnocie ?

7. Jak realizuje się zasadę wspólnoty dóbr we wspólnocie ?

8. Działalność "ad intra" i "ad extra", a wzrost duchowy wspólnoty. 9. Czy wspólnota jest instytucją totalną?

10. Czy możliwe jest utworzenie wspólnoty o zasięgu "makro"?

11. Jakie czynniki destabilizują wspólnotę?

12. Elementy wspólne i rozłączne wspólnot w znaczeniu socjologicznym i religijnym.

13. Wspólnoty pozareligijne i ich cele.

14. Wspólnota jako struktura emergentna.

15. Funkcjonowanie wspólnoty (consensus, czy demokracja).

Po sformułowaniu problemu badawczego i wymienionych zagadnień szczegółowych przyjęto następujące hipotezy: 
O. Wspólnoty parafialne ruchów odnowy realizują zadanie jednoczenia społeczności lokalnej "makro" i "mikro" tworząc społeczność "mezostrukturalną" o tyle, o ile wśród uczestników następuje trwała internalizacja postaw połączona z konwersją i służbą na rzecz tej wspólnoty.

1. Ruch "Światło - Życie" jako struktura ogólnopolska, mając swoje agendy poza granicami kraju tworzy strukturę makrospołeczną.

2. Każda wspólnota parafialna Ruchu jest strukturą pośrednią między małą grupą formacyjną czy diakonijną, a Ruchem jako całością. W niej dokonuje się zasadnicza internalizacja przez jednostkę postaw propagowanych przez Ruch.

3. Mała grupa formacyjna jest najlepszym środowiskiem do zachodzenia procesu konwersji, spełnia to zadanie jako mikrostruktura społeczna.

4. Obowiązek martyrii (świadectwa) słowem i czynem, powoduje przenoszenie przez osoby, które zinternalizowały postawy Ruchu, wzorów i zachowań oraz wzajemnych stosunków, ze wspólnoty Ruchu do życia codziennego.

5. Konwersja (metanoia) przemiana duchowa jest podstawą budowania wspólnoty. Tylko "Nowy Człowiek" może tworzyć "Nowe Życie" (wspólnotę) jako nośnik "Nowej Kultury".

6. Pozornie sprzeczne ze sobą zasady, we wspólnocie mają swój sens na zasadzie wzajemnej służby wobec pozostałych jej członków.

7. Wspólnota dóbr we wspólnocie następuje, gdy istnieje ona dostatecznie długo, by takie dobra wypracować, lub gdy przeobraża się w Stowarzyszenie Życia Konsekrowanego.

8. Działalność "ad intra" we wspólnocie powoduje jej wewnętrzne jednoczenie i wzrost, natomiast działalność "ad extra" powoduje uznanie w oczach innych i wzrost powołań do życia w jej szeregach.

9. Wspólnota, pomimo niektórych jej cech nie jest instytucją totalną ponieważ przynależność do niej uczestników jest całkowicie dobrowolna, uczestnicy w każdym momencie mają możliwość wolnego wyboru odnośnie swojej dalszej drogi życiowej, nikt nie ogranicza im swobody działania wewnątrz wspólnoty.

10. O ile stworzenie wspólnoty o zasięgu "mezo" byłoby możliwe na gruncie społecznym, o tyle utworzenie wspólnoty o zasięgu "makro" jest możliwe tylko na gruncie religijnym (vide, pielgrzymki papieża).

11. Do czynników destabilizujących wspólnotę należy brak przebojowości w działaniu, zwłaszcza w sferze "ad extra", brak całkowitej internalizacji postaw propagowanych przez wspólnotę, nie do końca przeprowadzony proces konwersji wskutek wadliwej formacji podstawowej uczestników, egoizm, w postawach niektórych członków wspólnoty i ich zły wpływ na pozostałych członków wspólnoty.

12. Elementy wspólne to struktury, metody działania, sposoby pozyskiwania nowych członków. Elementy rozłączne to punkt odniesienia (hierarchia wartości nadrzędnych), cele wspólnoty, interakcje między członkami.

13. Do pozareligijnych wspólnot interpersonalnych zaliczyć można w ramach mezostruktur - rody, wspólnoty sąsiedzkie, w ramach mikrostruktur - rodzinę, niektóre zespoły psychokorekcyjne i kluby AA.

14. Wspólnota jest tworem emergentnym ponieważ nie zostaje utworzona jako suma wartości i sposobów działania poszczególnych jej członków, lecz jednocząc wszystkich w sobie tworzy odmienną(nową) jakość społeczną i religijną, różną od elementów składowych.

15. Wspólnota zarówno w ujęciu społecznym, jak i religijnym funkcjonuje na zasadach ujętych w pojęcie consensus. Jednak we wspólnocie religijnej za podejmowanie decyzji odpowiedzialna jest jedna osoba. 


\section{Przypisy do rozdziału IV}

1. A. Borowski: Więź społeczna w parafii, potrzeba budowania jedności, Szczecin 1992 , s. 67.

2. W. Makarczyk: Studia nad aparaturą pojęciową socjologii, Warszawa 1991, s. 188.

3. E. Mokrzycki: Założenia socjologii humanistycznej, Warszawa 1971 s. 41-110.

4. W. Makarczyk: op. cit. s. 189.

5. E. Husserl: Logische Untersuchungen, Halle 1913, s. 294-295.

6. A. Tarski: Pojęcie prawdy w językach nauk dedukcyjnych, Warszawa 1933, s. 67.

7. K. Ajdukiewicz: Język i poznanie, warszawa 1985, t. I, s. 223.

8. Ibidem: s. 350-352, t. 2.

9. Ibidem: s. 197-200, t. 1.

10. J. Karpiński: Przyczynowość w badaniach socjologicznych, Warszawa 1985, s. 106.

11. A. Sosnowski, J. Walkowiak: Przystosowanie młodzieży, a integracja społeczna, Szczecin 1987.

12. P. Wejdland: Obrazy grup społecznych, Warszawa 1991, s. 19-51.

13. F. Grucza: Terminologia - jej przedmiot, status, znaczenie w: Teoretyczne postawy terminologii (red. F. Grucza) Wrocław 1991, s. 17-18.

14. A. Wójtowicz: Przesłanki socjologicznych kategorii kultury religijnej w: Studia Religioznawcze 19/85, s. 231-248.

15. A. Podgórecki: Socjotechnika, Warszawa 1970, s. 51.

16. B. Chełstowski: Pojęcia, wskaźniki, metody i korelaty integracji grupy w literaturze socjometrycznej, w: Studia Socjologiczne 1/66, s. 155-156.

17. Ibidem: s. 178.

18. Ibidem: s. 186-187.

19. P. Abell: Modele w socjologii, Warszawa 1975, s. 201.

20. M. Libiszowska - Żółtkowska: Postawy inteligencji wobec religii, Warszawa 1991, s. 15-27.

21. H. Grzymała - Moszczyńska: Psychologia religii, Kraków 1991, s. 9-17.

22. T. Zysk: Jak badać przekonania religijne, w: Religia a życie codzienne (red. I. Borowik). Kraków 1991, cz. II s. 47-48.

23. J. Mariański: Kierunki badań polskiej socjologii religii w latach osiemdziesiątych, w: Życie Katolickie I/90, s. 45-65.

24. J. Szczepański: Elementarne pojęcia socjologii, Warszawa 1970, s. 23-24. 
25. K. Czekaj: Zastosowanie obserwacji uczestniczącej i wywiadu z informatorem ekspertem społecznym, do badania społeczności lokalnych. w: Społeczności lokalne regionu Górnego Śląska, Wrocław 1987, s. 183-204.

26. R. Mayntz: Wprowadzenie do metod socjologii empirycznej, Warszawa 1985, s. 111-130.

27. S. Nowak: Metodologia badań socjologicznych, Warszawa 1970, s. 126-127.

28. A. Sosnowski: Obserwacja uczestnicząca, osiągnięcia i perspektywy, w: Z metodologii i metodyki socjologicznych badań terenowych (red. K. Lutyńska), Warszawa 1985, s. $125-128$.

29. D. Maszczyk, A. Radzewicz: Metody badań w naukach społecznych, Katowice 1979, s. 47-52.

30. Z. Gostkowski: Analizy i próby technik badawczych w socjologii, Warszawa 1990, s. 172.

31. Ludzie, wiara, Kościół (red. B. Cywiński): Warszawa 1966, s. 389-400.

32. A. Borowski: Metoda obserwacji uczestniczącej w badaniach z zakresu socjologii religii, w: Studia Sociologica 5/1993, Szczecin, s. 109-114.

33. Ibidem: s. 115-124.

34. D. Maszczyk: Metody ... op. cit., s. 49-52.

35. P. Socha: Rozwój orientacji religijnej i światopoglądowej, Kraków 1992, s. 29-41.

36. P. Socha: W poszukiwaniu istoty religijności, Psychologiczne badania związku religijności z autonomią, w: Nomos 1/92, s. 144-118. 


\section{BADANIA SZCZEGÓŁOWE WSPÓLNOTY JAKO KATEGORII SOCJOLOGICZNEJ I RELIGIJNEJ}

\section{1. Charakterystyka badanej wspólnoty}

Dla większości (80 \%) oazowiczów Ruch “Światło - Życie” jest najważniejszą grupą odniesienia, ze wszystkich, do jakich należą. We wspólnocie Ruchu czują się dobrze, jej działalność uznają za potrzebną, w większości aprobują zakładane formy działalności. Tylko znikomy odsetek (5\%) odczuwa potrzebę jeszcze silniejszego związania z Ruchem. Dość silnej identyfikacji z Oazą nie towarzyszy wyobcowanie w klasie szkolnej. W niektórych klasach uczy się kilku uczestników wspólnoty, co ułatwia nawiązywanie kontaktów z rówieśnikami. W kilku przypadkach odnotowano fakt nieporozumień między rówieśnikami (15\%) co wynikało z przynależności do różnych grup subkulturowych bazujących na muzyce rockowej.

Część uczestników badanej wspólnoty pochodzi z rodzin niepełnych i patologicznych (alkoholizm), co może wpływać na poszukiwanie przez nich środowiska, gdzie mogliby się czuć akceptowani i rozumiani. Właśnie te osoby $(25 \%)$ starają się manifestować ważność przyjaźni i wzajemnego zrozumienia. Często na drugim miejscu stawiają oni w hierarchii grup (poza oazą) grupy rówieśnicze, a nie rodzinę. Role pełnione we wspólnocie oazowej związane są z nieco innymi oczekiwaniami, jakie stawia się wobec wykonawców, niż to ma miejsce np. w klasie szkolnej, czy grupie rówieśniczej.

W porównaniu do wcześniej przeprowadzanych badań zmalała liczba osób pełniących rolę buntownika (35\%) i innowatora - zabawiacza (20\%) na rzecz obserwatora i konformisty (45\%). W wypowiedziach uczestników dominuje przekonanie, iż jest to rezultatem wprowadzenia nauczania religii do szkół, co zapobiega alienacji oazowiczów w środowisku szkolnym. Często członkowie Ruchu są "prawą ręką" katechety podczas zajęć duszpasterskich w szkole (1).

W mieście, gdzie stopa bezrobocia sięga $40 \%$, ostatni blok mieszkalny oddano do użytku kilka lat wcześniej młodzież szkolna zwłaszcza na etapie szkoły średniej bardzo rzadko wypowiada się pozytywnie o miejscu swego zamieszkania i perspektywach na przyszłość. Dotyczy to także uczestników badanej wspólnoty. Z uwagi na systematyczne ograniczanie środków na kulturę i oświatę, baza do tego typu zajęć maleje. Tymczasem istnienie, atrakcyjność programów różnych placówek z terenu badanej społeczności lokalnej ma wpływ na uczestnictwo w działalności tych placówek. Oazowicze nadal wskazują na Kościół, jako środowisko faktycznego uczestnictwa w życiu społeczności lokalnej. Kościół jest bowiem instytucją, ale i wspólnotą, w ramach której Ruch się rozwinął. Dla wspólnot Ruchu jest on autorytetem, a wskazania ostatniego Soboru Watykańskiego są dla oazy drogowskazem do działalności i życia w społeczeństwie.

Od reszty społeczeństwa młodzież odróżniana jest dzięki poglądom, zainteresowaniom, formom aktywności, różnicom demograficznym, a ostatnio zwłaszcza ekonomicznym. Bardzo nisko oazowicze oceniają poziom integracji współczesnej polskiej młodzieży. Przynależność do Ruchu ma pokonać te kategorialne rozbicie. Jak bumerang wraca kwestia większego zainteresowania się problemami młodzieży przez gremia diecezjalne. Od kilku lat narasta problem dewaluacji wielu wzorców osobowych i ideałów postępowania. Zgodnie z zasadą, że: "życie nie lubi pustki" młodzież szybko odnajduje "wzorce" w massmediach (kino, muzyka). Dla uczestników badanej wspólnoty takimi wzorcami jest Chrystus, jego Matka, jak również papież - Jan Paweł II. Duży nacisk oazowicze kładą na wizerunek dobrego chrześcijanina, jako tego, który łagodzi spory i konflikty. 
Pomimo niesprzyjających warunków w lokalnej społeczności większość uczestników badanej wspólnoty zmierza w życiu do osiągnięcia odpowiedniego miejsca w społeczeństwie i względnej stabilizacji materialnej, która wiąże się ze zdobyciem pracy. Obecnie bowiem znakomita większość osób opuszczających szkoły powiększa szeregi bezrobotnych (75\%). Tylko niektórym udaje się znaleźć pracę, albo kontynuować naukę w szkołach wyższych. W życiu codziennym oazowicze pragną być perfekcjonistami, osiągnąć doskonałość zawodową i moralną. Dla wszystkich oazowiczów niezwykle istotne są cele religijne.

W całej formacji oazowej wiele akcentów kładzie się na przyjaźń, radość, aktywność życiową, zorientowanie na innych oraz kierowanie się głosem sumienia. Preferowanie określonych wartości owocuje później wyborem autorytetu i antyautorytetu. Do autorytetów, poza wspomnianymi wyżej, oazowicze zaliczają niektórych księży z rodzimej parafii, jak i osoby związane z działalnością Oazy na szczeblu ogólnopolskim, czasami członków rodziny, bardzo rzadko członków grup rówieśniczych. Większość uczestników badanej wspólnoty potrafi określić własne antyautorytety. W większości przypadków dotyczą one postaci z życia politycznego kraju.

Kilku uczestników badanej wspólnoty bierze udział w amatorskiej działalności artystycznej tworząc zespół muzyczny, nieliczni zajmują się także działalnością na forum kółka teatralnego. Większość badanej wspólnoty $(65 \%)$ nie posiada zainteresowań artystycznych. Z uwagi na radykalne ograniczenie działalności szkolnych organizacji i kółek zainteresowań działalność we wspólnocie Ruchu pozostaje dla wielu uczestników jedyną formą udziału w kulturze. Godny odnotowania jest fakt uczestnictwa wielu członków badanej wspólnoty w życiu kulturalnym najbliżej położonych aglomeracji (Szczecin, Poznań) poprzez wyjazdy do teatrów i oper. Badana wspólnota bierze także udział w kulturze instytucjonalnej poprzez wydawanie własnego czasopisma "Pustynia" w nakładzie 100 egzemplarzy. Łamy tego miesięcznika są okazją do zaprezentowania szerszemu forum działalności wspólnoty i jej punktu widzenia na wiele spraw $z$ otaczającego świata.

Większość badanych osób (90 \%) charakteryzuje się umiejętnością wyboru programu TV, czy książki stosownie do posiadanych zainteresowań. Świadczy to o umiejętności odróżniania rzeczy wartościowych i o pożytecznym spędzaniu wolnego czasu.

Wszyscy badani są nie tylko wierzący, ale i systematycznie praktykujący, co jest zawarte m.in. w wymaganiach i specyfice Ruchu oazowego.

W kwestii samostanowienia zdania były podzielone. Obecnie większość (55 \%) uważa, że młodzież to przede wszystkim grupa, na kolejnym miejscu dopiero pojawiają się jednostki. Niezmiernie rzadko zdarzają się jednostki, która chciałaby stanowić o swoim losie, bez konsultacji z żadną grupą odniesienia (np. oazą). Na taką sytuację niewątpliwie ma wpływ niepewność jaka towarzyszy zmianom systemowym od paru lat.

Wśród rodziców młodzieży oazowej najliczniejszą grupę stanowią osoby zatrudnione w sektorze handlu i usług, następnie w zakładach państwowych i prywatnych. U niemal połowy uczestników $45 \%$ przynajmniej jedno z rodziców pozostaje na zasiłku dla bezrobotnych, u $10 \%$ dotyczy to obojga rodziców. Większość rodziców posiada wykształcenie średnie (60 \%), niewielka część wyższe (10 \%) i ok. 30 \% zawodowe. Zdecydowana większość rodziców (95\%) nie bierze udziału w życiu politycznym $\mathrm{z}$ uwagi na zrelatywizowanie się wielu wcześniejszych autorytetów. Wśród pozostałych $5 \%$ wszyscy opowiadają się za partiami wywodzącymi się z ruchu posierpniowego. Przywołane zmienne dotyczące rodziców oazowiczów mają istotny wpływ na postawy i poglądy dzieci. Mogą również mieć znaczenie przy wyborze określonej orientacji światopoglądowej oraz miejsca afiliacji (2).

Wspólnota Ruchu, będąca obiektem badań, przeprowadzanych przede wszystkim metodą obserwacji uczestniczącej, powstała w 1974 roku. Działa na terenie parafii miejsko - 
wiejskiej typu zakonnego, w piętnastotysięcznym miasteczku. Wspomniana parafia posiada opinię jednej $\mathrm{z}$ najtrudniejszych $\mathrm{w}$ diecezji. Powodem takiej sytuacji jest duży stopień obojętności religijnej i szukania ucieczki w alkoholizmie. Położona jest na terenie o stosunkowo małym uprzemysłowieniu. Aktualnie pracę duszpasterską prowadzi 6 księży i 10 katechetek świeckich (bez specjalistycznego przygotowania). "Dominicantes" waha się w takiej parafii w granicach $20 \%$, a "Communicantes" w granicach 5\% wiernych parafii.

W chwili obecnej działa w parafii 6 wspólnot życia religijnego. Należy do nich tzw. Trzeci Zakon św. Franciszka liczący około 30 osób, prowadzący działalność na niwie modlitwy. Żywy Różaniec skupia w swych szeregach ok. 170 osób prowadząc działalność także na niwie modlitwy. Wraz z chórem parafialnym liczącym ok. 40 osób stanowią one wspólnoty realizujące tzw. religijność tradycyjną. W ostatnich latach z uwagi na małą aktywność doszło do rozwiązania wcześniej istniejących wspólnot, takich jak Neokatechumenat, wspólnota Marianek. Praktycznie nie prowadzi działalności Ruch Trzeźwościowy imienia św. Maksymiliana Kolbego i duszpasterstwo niewidomych. Do pozostałych wspólnot działających na terenie parafii należy Duszpasterstwo Służby Liturgicznej, zrzeszające ok. 80 członków. Głównym elementem działalności tej wspólnoty jest oprawa liturgiczna wszystkich nabożeństw oraz własna formacja według stopni ministrantury.

Wspólnota Zespołu Synodalnego licząca aktualnie 10 osób prowadzi działalność głównie formacyjną opartąna ogólnopolskich materiałach formacyjnych własnych przemyśleniach i wynikającą ze spotkań między poszczególnymi Zespołami Synodalnymi z innych miejscowości. Wspólnota Ruchu "Światło - Życie" zrzesza w badanej parafii ok. 25 osób. Działalność tej wspólnoty zgodnie $\mathrm{z}$ założeniami Ruchu dzieli się na dwa komplementarne sektory: formacyjny i diakonijny (służebny na rzecz parafii). Polega ona na propagowaniu odnowionej liturgii według wskazań Vaticanum II, poprzez aktywny udział w Zgromadzeniach Eucharystycznych. Większość uczestników $65 \%$ stanowią uczniowie szkół podstawowych, $30 \%$ to uczniowie szkół ponadpodstawowych, a $5 \%$ to osoby pracujące lub bezrobotne. W rozbiciu na poszczególne stopnie formacyjne wspólnota Ruchu przedstawia się następująco: przed I stopniem Oazy Dzieci Bożych (ODB) - 7 osób

I stopień ODB - 4 osób

II stopień ODB - 6 osób

III stopień ODB - 4 osób

O stopień Oazy Żywego Kościoła (OŻK) - 7 osób

II stopień OŻK - 2 osoby.

Animatorzy - osoby po ukończonej formacji podstawowej, zaangażowani w działalność konkretnej diakonii (służby) na rzecz wspólnoty Ruchu i parafii - 2 osoba. Moderator (opiekun) W zależności od stopnia zaangażowania w działalność Ruchu - 1 osoba. Moderatorem zostaje zazwyczaj osoba duchowna, choć czasami zdarzają się wyjątki i funkcję taką pełnią też ludzie świeccy. Od kilku lat jest propagowana w omawianej wspólnocie zasada świeckiego odpowiedzialnego za Ruch w danej parafii. Przejęcie większości obowiązków od moderatora przez świeckiego odpowiedzialnego jest przeprowadzane w duchu zmian soborowych i najnowszych dokumentów Katolickiej Nauki Społecznej, mówiących o roli świeckich w działalności Kościoła.

Uczestnicy badanej wspólnoty należą do niej co najmniej od kilku lat (80\%). Byli oni uczestnikami przynajmniej jednej Oazy Rekolekcyjnej latem, większość rozpoczęła swoją oazową formację od Oazy Dzieci Bożych w szkole podstawowej. Najczęstszym motywem przystąpienia do wspólnoty była obecność w nim ich koleżanek i kolegów. Ich samych 
zazwyczaj pociągała atrakcyjność formy działania oferowana przez oazę oraz możliwość pogłębienia wiary w sposób mniej konwencjonalny, niż na zajęciach w szkole. Poziom wiedzy na temat Ruchu wzrasta w miarę postępów na drodze formacji.

Aktualnie Ruch jako struktura ogólnopolska znajduje się w stadium stagnacji jednak nie wiąże się to z kryzysem Ruchu lecz oczyszczeniem jego szeregów z przypadkowych uczestników. Dla niektórych uczestników denerwujące bywają braki organizacyjne i sugerowana pozorna pobożność, za którą nie idzie działanie. Występująca niekiedy nieumiejętność prowadzenia grup przez animatorów wynika $\mathrm{z}$ braku całościowej internalizacji postaw proponowanych przez Ruch, jako również nie do końca przeprowadzonego procesu konwersji. W badanej wspólnocie prowadzenie grup formacyjnych rozpoczyna się często przed zakończeniem własnej formacji oazowej. Dostrzegane niedociągnięcia i braki nie wpływają jednak na spontaniczność uczestnictwa $\mathrm{w}$ Ruchu.

Głębokie zaangażowanie w prace wykonywane w ramach Ruchu oazowego prowadzi do przeobrażeń w sferze światopoglądowej i psychicznej. W cytowanych świadectwach na temat konwersji większość badanych uważa, że "zmieniła się na lepsze". Fakt ten jest zgodny $\mathrm{z}$ oczekiwaniami posiadanymi w momencie przystąpienia do Ruchu, chociaż ich realizacja nie zawsze jest całkowita (3).

W ramach badanej wspólnoty oazowej udało się wyodrębnić trzy typy uczestników (twórcy, odtwórcy i obserwatorzy):

- twórcy dostrzegają drugiego człowieka, jego problemy duchowe oraz życiowe, w myśleniu i działaniu starają się być spontaniczni, co nie oznacza chaotyczni. Mają z reguły duży krąg przyjaciół, nie mają wyraźnych wrogów. Z socjologicznego punktu widzenia są gwiazdami socjometrycznymi. Twórców cechuje także duża odpowiedzialność za własne słowa i czyny. Wobec otaczającego świata są optymistami. W badanej wspólnocie należy do nich ok. $25 \%$ uczestników.

- odtwórcy także dostrzegają problemy drugiego człowieka, jednak w ich przełamywaniu i (szerzej) publicznych wystąpieniach brak im przebojowości, spontaniczności. Zazwyczaj zgadzają się ze zdaniem twórców. Najważniejszą dla nich zasadą życiową jest przekazanie miłości. Większość uważa, że dzięki wspólnocie mogą przełamywać własne kompleksy. Wspólnota Ruchu rodzi w nich poczucie akceptacji i bezpieczeństwa. Dzięki uczestnictwu w niej odnajdują swoją ludzką wartość. W badanej wspólnocie stanowią on i 60 \% uczestników.

- obserwatorzy - o ile to możliwe starają się lokować na uboczu wspólnoty, nie rzucać się w oczy, nie wypowiadać się, gdy wyraźnie nie zostaną o to poproszeni. Na zewnątrz czasami prezentują postawę buntu wobec otaczającej rzeczywistości (także wspólnotowej). Z życia społecznego jako argument często przytaczają nudę i brak życzliwości w otoczeniu. Pesymistycznie nastawieni są do rzeczywistości i możliwości rozwiązania istniejących problemów oraz podziałów w społeczeństwie. Wobec otaczającego świata mimo werbalnego buntu są nastawieni konformistycznie. Do Ruchu i jego działalności są nastawieni raczej bezkrytycznie. W badanej wspólnocie stanowią około $15 \%$ ogółu uczestników. Struktura badanej wspólnoty odnośnie liczby uczestników i animatorów na przestrzeni dwudziestu lat jej istnienia przedstawia Tabela $\mathrm{nr} 1$. 
Tabela 1. Struktura badanej wspólnoty odnośnie liczby uczestników i animatorów na przestrzeni dwudziestu.

\begin{tabular}{|c|c|c|}
\hline Rok & $\begin{array}{c}\text { Ilośćc } \\
\text { uczestników }\end{array}$ & $\begin{array}{c}\text { Ilość } \\
\text { uczestników }\end{array}$ \\
\hline 1974 & 5 & 0 \\
\hline 1975 & 8 & 0 \\
\hline 1976 & 12 & 2 \\
\hline 1977 & 17 & 4 \\
\hline 1978 & 23 & 5 \\
\hline 1979 & 29 & 6 \\
\hline 1980 & 35 & 9 \\
\hline 1981 & 30 & 7 \\
\hline 1982 & 25 & 5 \\
\hline 1983 & 30 & 6 \\
\hline 1984 & 30 & 5 \\
\hline 1985 & 25 & 4 \\
\hline 1986 & 35 & 6 \\
\hline 1987 & 55 & 7 \\
\hline 1988 & 65 & 8 \\
\hline 1989 & 50 & 5 \\
\hline 1990 & 35 & 4 \\
\hline 1991 & 50 & 4 \\
\hline 1992 & 75 & 5 \\
\hline 1993 & 50 & 4 \\
\hline 1994 & 40 & 3 \\
\hline 1995 & 25 & 2 \\
\hline
\end{tabular}

źródło: opr. własne. 


\section{2. Weryfikacja hipotez badawczych (na podstawie studium przypadku wspólnoty oazowej)}

Materiał badawczy uzyskany w wyniku przeprowadzonej obserwacji uczestniczącej oraz wywiadu bezpośredniego $\mathrm{z}$ poszczególnymi członkami wspólnoty został usystematyzowany według przyjętych hipotez badawczych, celem ich weryfikacji, względnie falsyfikacji.

Hipoteza pierwsza: Ruch "Światło - Życie” jest strukturą o zasięgu makro. Korzystając z wcześniej przytaczanej definicji makrostruktury obejmującej zespoły, zrzeszenia, grupy etniczne, czy narody - w najszerszym znaczeniu "Oaza" kojarzy się uczestnikom badanej wspólnoty z wielkim Ruchem odnowy Kościoła, obejmującej swymi agendami nawet kilka krajów Europy i Ameryki Łacińskiej (4).

Kościół jest przy tym postrzegany jako wspólnota uczniów Chrystusa na ziemi, jest miejscem spotkania z Bogiem. Wspólnota jest rozumiana przez członków Ruchu jako grupa ludzi, których łączą wspólne wartości, przeżycia, normy, całkowite zaufanie do siebie, wzajemna miłość i przyjaźń. Kościół lokalny łączą przy tym z Kościołem powszechnym wyznawane wartości, relacja podporządkowania, wynikająca także $\mathrm{z}$ hierarchiczności Kościoła lecz służąca realizacji jednego celu (wspólnego dla wszystkich Kościołów lokalnych).

Z Kościoła powszechnego, Kościoły lokalne odróżniają się przede wszystkim zakresem oddziaływania, posiadaniem silniejszej więzi wśród wyznawców oraz lepszą wzajemną znajomością problemów, trudności w codziennym życiu.

W badanej wspólnocie większość uczestników wyraża opinię, że Oazę przeżywa jako strukturę ogólnopolską w zasadzie tylko kilka razy w życiu, podczas rekolekcji letnich względnie zimowych, gdzie spotykają się uczestnicy praktycznie z całej Polski. Nieliczne osoby z wyższych stopni formacyjnych oraz animatorzy do podanych wyżej dodali Centralną Oazę Matkę (COM), Krajową Kongregację Odpowiedzialnych (KKO), pielgrzymki i spotkania ogólnopolskie (np. dni wspólnoty).

W ciągu trwania roku formacyjnego raczej nie ma okazji do przeżywania Ruchu jako makrostruktury. W badanej wspólnocie istnieje dość dobra orientacja (zwłaszcza W wyższych stopniach formacyjnych), odnośnie innych ruchów odnowy soborowej, o zasięgu ogólnopolskim. Zaliczyć do nich można Charyzmatyczną Odnowę w Duchu św. Neokatechumenat, Rodzinę Rodzin, Ruch "Wiara i Światło" (tzw. Muminki), Wspólnotę Błogosławieństw. Podobnie przedstawia się znajomość ogólnopolskich struktur Ruchu Oazowego, do których respondenci zaliczyli Centralną Diakonię Jedności, mającą swoją siedzibę w Krościenku nad Dunajcem, Diakonię Moderacji, KKO, COM oraz poszczególne diakonie specjalistyczne, mające zasięg ogólnopolski. Poprawnie wymieniła moderatorów Ruchu tylko nieliczna grupa uczestników badanej wspólnoty. Pierwszym moderatorem krajowym, a jednocześnie założycielem Ruchu był ks. F. Blachnicki (zm. 1987). Sprawował on swoją funkcję w latach 1954 - 1982. W latach 1982 - 1985 jego obowiązki pełnił ks. W. Danielski (zm. 1985). Od 1985 r. do chwili obecnej moderatorem krajowym Ruchu jest ks. H. Bolczyk. Z ramienia Episkopatu Polski, Ruchem Oazowym opiekuje się bp. G. Biernacki. O tym fakcie we wspomnianej wspólnocie wiedziała tylko jedna osoba. Nie było większych problemów z wyjaśnieniem skrótu KKO. Przy badaniu świadomości uczestników zwrócono uwagę na znajomość zakresu działania poszczególnych instytucji o zasięgu ogólnopolskim. Diakonia moderacji zajmuje się według respondentów ukierunkowywaniem posług w pracy całego Ruchu oraz dostosowywanie tejże posługi do aktualnej sytuacji Kościoła i świata. Pielgrzymki i inne ogólnopolskie spotkania Ruchu są bardzo potrzebne, twierdzą uczestnicy, 
z uwagi na rozwijanie świadomości Oazy jako wspólnoty w skali makro, są też jedną z możliwości wymiany doświadczeń z funkcjonowania poszczególnych wspólnot.

Wszyscy członkowie badanej wspólnoty stwierdzili, że nie jest możliwe zrealizowanie powołania chrześcijańskiego poza Kościołem. Chrześcijanin ze swej natury powinien żyć we wspólnocie uczniów Chrystusa, jak stwierdził jeden $z$ animatorów. Nowością w niniejszej pracy jest zastosowanie przy badaniu omawianej wspólnoty tzw. Skali Spójności Wspólnoty, która jest zmodyfikowaną wersją Inwentarza Życia Wewnętrznego (A. Latały i P. Sochy). Wszyscy uczestnicy badanej wspólnoty $\mathrm{z}$ mniejszym lub większym przekonaniem stwierdzili, że Kościół powszechny, także ten w Polsce, stanowi wspólnotę. Podobne odpowiedzi były udzielane na pytania dotyczące Ruchu Oazowego i innych ruchów odnowy soborowej o zasięgu ogólnopolskim. Powyższe stwierdzenia pozwalają na zweryfikowanie pierwszej hipotezy badawczej. Struktury diecezjalne Diakonii Jedności występują we wszystkich 39 polskich diecezjach. Struktury lokalne istnieją w większości polskich parafii.

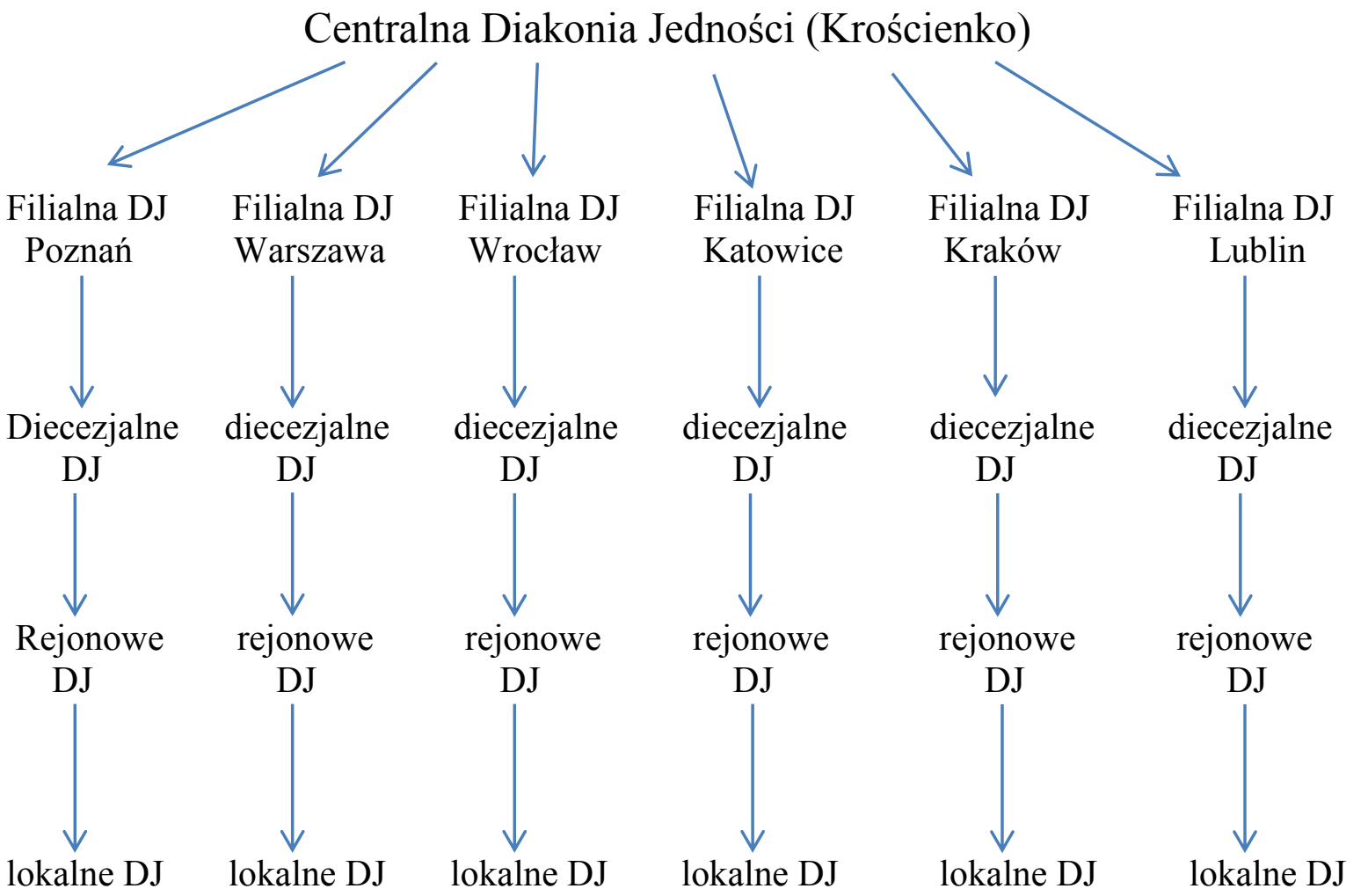

Schemat 1. Struktura organizacyjna Diakonii Jedności Ruchu Oazowego.

Struktury diecezjalne Diakonii Jedności występują we wszystkich 39 polskich diecezjach. Struktury lokalne istnieją w większości polskich parafii.

Hipoteza druga: Każda wspólnota parafialna Ruchu jest strukturą pośrednią (mezostrukturą), między małą grupą formacyjną lub diakonijną, a Ruchem jako całością. W tej strukturze pośredniej dokonuje się zasadnicza internalizacja jednostki z postawami proponowanymi przez Ruch. 
Za mezostrukturę społeczną uważać należy określony typ łączności przestrzennej, zawierający elementy więzi społecznej, określonych zbiorowości społecznych mających poczucie odrębności od innych zbiorowości, lecz stanowiące z nimi komplementarną całość (5).

Świadomość historii wspólnoty parafialnej Ruchu, w której przeprowadzono badania nie wygląda najlepiej. Co prawda większość uczestników potrafi podać rok powstania wspólnoty, jednak tylko kilka osób potrafi powiedzieć coś więcej z historii wspólnoty w latach siedemdziesiątych i osiemdziesiątych. Wszyscy uczestnicy deklarują żywą łączność z Bogiem, jako wynik uczestnictwa we wspólnocie Ruchu na szczeblu lokalnym. Uczestnictwo we wspólnocie pomaga im być (stawać się) dobrymi ludźmi. Większość uważa także, że wspólnota religijna mimo wad ludzi ją tworzących jest zawsze dziełem Boga. Dzięki formacji we wspólnocie parafialnej większość uczestników uważa, że to przez nią dokonał się rozwój w wierze. W chwilach krytycznych, jak podali respondenci, można liczyć na pomoc, jak nie całej wspólnoty, to przynajmniej kilku jej uczestników. Potwierdzają to wyniki uzyskane z analizy Skali Spójności Wspólnoty. Dla każdego uczestnika bycie we wspólnocie jest postrzegane jako wolność, a nie jako zniewolenie, na uzasadnienie czego przytaczane są argumenty, że podstawą każdej wspólnoty (nie tylko religijnej) jest wolność jej uczestników. Uczestnicy nie narzucają swoich poglądów innym osobom, co najwyżej poprzestają na ich zasygnalizowaniu. Większość uczestników badanej wspólnoty stara się wysłuchiwać poglądów innych osób i przyjmować je, jeżeli się z nimi zgadzają. Część respondentów (50 \%) uważa, że o człowieczeństwie decyduje posiadanie własnego zdania na każdy temat jednak pozostali zgodnie twierdzą, że nie tylko to decyduje o człowieczeństwie.

Poprzez uczestnictwo w Ruchu na szczeblu parafialnym większość uczestników posiada spójny system wartości życiowych. W niektórych przypadkach uczestnicy podkreślali większy udział w internalizacji określonych wartości wspólnoty Ruchu, niż np. rodziny, szkoły, grupy rówieśniczej. W innych, zazwyczaj dominowała rodzina i wspominana grupa rówieśnicza. Większość (ponad $90 \%$ ) badanych respondentów stwierdziła, że z natury są posłuszni, a uczestnictwo we wspólnocie jest okazją do praktykowania się w nim. Dla większości uczestników Ruchu w badanej parafii stosunek do wspólnoty, w ciągu kilku lat udziału w jej życiu, nie uległ zmianie.

Wyniki tych badań zostały potwierdzone odpowiednimi sekwencjami Skali Spójności Wspólnoty. Stosunkowo duże wątpliwości budziło pytanie, czy uczestnik jakiejkolwiek wspólnoty powinien pozostawać w jej cieniu, czy też zawsze zaznaczać swoją obecność i swoje zdanie na dany temat.

Proporcje udzielonych odpowiedzi oscylowały w granicach $50 \%$ po obu stronach. Animatorzy opowiedzieli się za wersją pierwszą (pozostanie w cieniu).

Poprzez różnorodność form pracy wspólnoty parafialnej Ruchu Oazowego istnieje wiele możliwości zaangażowania się w posłudze na rzecz jedności parafii. W związku z tym, łatwiej jest znaleźć każdemu z uczestników Ruchu posługę, w której czułby się najlepiej, którą mógłby najlepiej wypełniać. Parafialna wspólnota daje także możliwość w miarę silnych więzi interpersonalnych, potrzebnych do funkcjonowania każdej wspólnoty. Niektórzy uczestnicy badanej wspólnoty, jak również osoby, które ją opuściły z różnych przyczyn w latach poprzednich utworzyły nieformalną grupę towarzyską, regularnie spotykającą się w tzw. Kawiarence. Dwoje animatorów należy do stowarzyszenia o nazwie Ruch Społeczny Katolików Świeckich, którzy niedawno powstał w badanej parafii. Wobec powyższego hipotezę drugą uznano za zweryfikowaną. 


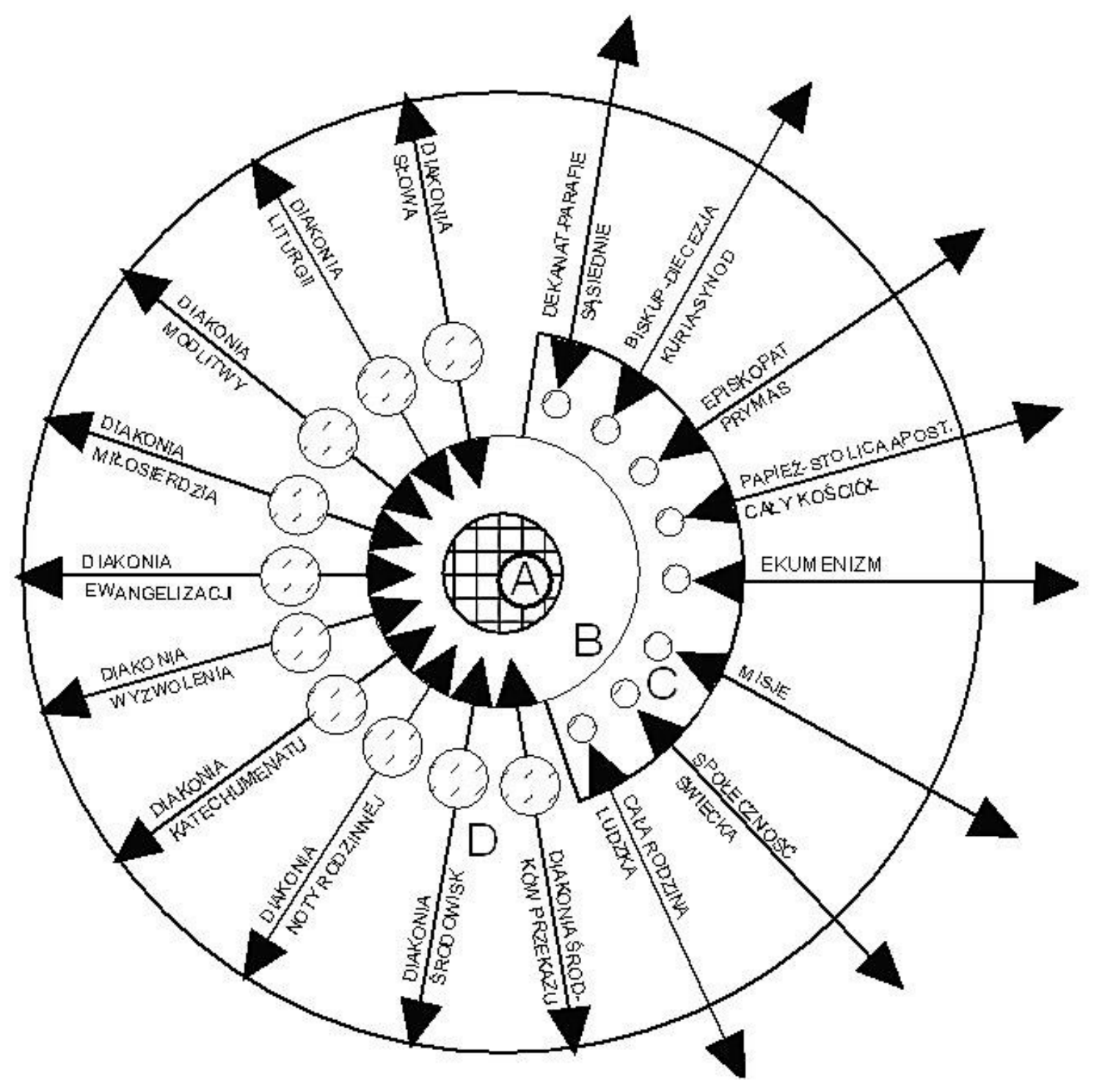

Schemat 2. Struktura Diakonii Wspólnoty Lokalnej (opr. własne).

A - ogólna diakonia wspólnoty, B - rada apostolska (duszpasterska), C - zespoły diakonii specjalistycznej wewnątrz wspólnoty, D- zespół(y) dla diakonii „na zewnątrz”.

Hipoteza trzecia: Mała grupa formacyjna jest optymalnym środowiskiem zachodzenia procesu konwersji, spełniając to zadanie jako mikrostruktura społeczna.

Mikrostrukturami są według przyjętej terminologii jednostki, ale i grupy społeczne pierwotne i wtórne. Wśród grup pierwotnych do najważniejszych należą te, które nazywamy wspólnoty (6).

Wszyscy uczestnicy badanej wspólnoty są jednocześnie uczestnikami spotkań w małych grupach formacyjnych poszczególnych stopni oraz diakonii. Każdy z nich uważa swoją małą grupę za wspólnotę, albo przynajmniej jej zalążek. Co do oceny małej grupy przez współuczestników, zdania raczej nie są do końca sprecyzowane. Większość respondentów waha się przy udzieleniu odpowiedzi. 
$\mathrm{Na}$ pytanie dotyczące animatora małej grupy, jako wzorca osobowego, większość uczestników stwierdza, że powinien on być wzorem, ale jednocześnie nie powinien przesłaniać swoją osobowością Chrystusa, który jest wzorem pierwotnym. W każdej małej grupie formacyjnej uczestnicy dzielą się na wyróżnione wyżej typy twórcy, odtwórcy i obserwatora. Nawiązując do wcześniejszych ustaleń, osobowość twórcza stara się prowadzić stałą konwersację $\mathrm{z}$ animatorem podczas spotkania, wypowiadając nierzadko przemyślane uwagi odnośnie tematu spotkania i poruszanych na nim kwestii. Uczestnicy tacy stanowią 25 \% całej wspólnoty. Uczestnicy spotkań formacyjnych o osobowości odtwórczej starają się akcentować, że zgadzają się ze zdaniem ogółu (nie sygnalizują własnego zdania). Stanowią oni ok. $60 \%$ respondentów. Pozostałe $15 \%$ osób stara się być jak najmniej zauważalna podczas spotkań formacyjnych, w nic się nie angażować, nie wypowiadać się za żaden temat. Powodem postawy obserwatora, jak ustalono, jest zazwyczaj niechęć do otwarcia się wewnętrznego wobec drugiego człowieka, spowodowana różnymi kompleksami i urazami. Wobec tych uczestników animatorzy starają się stosować zindywidualizowane podejście, mające na wstępie za zadanie, doprowadzenie do samoakceptacji u tych osób. Obowiązek aktywnego uczestniczenia $\mathrm{w}$ spotkaniach formacyjnych wynika $\mathrm{z}$ samej istoty formacji prowadzonej metodą przeżyciową. Osoby, które nie przeżywają we własnym życiu prawd, które są tematem poszczególnych spotkań formacyjnych, z czasem odchodzą ze wspólnoty, z uwagi na brak postępów w procesie konwersji. Większość uczestników badanej wspólnoty spotyka się ze sobą $w$ mniejszych lub większych grupach także poza spotkaniami formacyjnymi, na gruncie towarzyskim, lub grupy rówieśniczej. Wszyscy uczestnicy zgodnie twierdzą, że poprzez uczestnictwo w małej grupie formacyjnej mogą lepiej przeżywać swoją obecność zarówno w Kościele lokalnym jak i powszechnym. Część respondentów świadczyła nawet o tym doświadczeniu wspólnoty w małej grupie formacyjnej, w miejscu pracy, nauki, grupach rówieśniczych, albo w rodzinie. Większość członków wspólnoty jest przekonana, że od ich własnej, czy wspólnotowej modlitwy dużo zależy, dużo spraw może ulec zmianie, w życiu ich samych i innych ludzi. Mała grupa formacyjna skupia zazwyczaj od 3 do 15 osób, przez co pozytywnie wpływa na powstawanie i rozwój kontaktów interpersonalnych.

Dla większości badanej wspólnoty obraz religii jaki wynoszą ze spotkań w małych grupach wpływa na ocenę przez nich innych dziedzin życia. Należy przy tym zaznaczyć, że dzieje się tak nie u wszystkich i nie zawsze.

Wiara pomaga uczestnikom małych grup formacyjnych odnaleźć głębszy sens wspólnoty z Bogiem i drugim człowiekiem.. Należy podkreślić, iż proces formacji w ruchu sprzyja wzrastaniu świadomości potrzeby formacji permanentnej, która jest obowiązkiem każdego chrześcijanina.

Informacje uzyskane w wyniku analizy Skali Spójności Wspólnoty, w zasadzie potwierdzają wcześniejsze wyniki z obserwacji uczestniczącej. Wszyscy badani respondenci, uważają, że jakość wspólnoty zależy od poziomu wzajemnego zrozumienia wewnątrz niej samej. O wiele łatwiej i szybciej można osiągnąć takie porozumienie przy mniejszych grupach, jednak przy większych także jest to możliwe.

Jest wiele powodów istnienia małych grup. Pierwszym $\mathrm{z}$ nich jest tworzenie chrześcijanom możliwości nawiązania podstawowych relacji osobowych pomiędzy sobą. W małej grupie wszyscy uczestnicy mogą poznawać się osobiście. Relacje te nacechowane są ciepłem i indywidualnym podejściem. Potrzeba relacji podstawowych istnieje wśród członków badanej wspólnoty, jeśli wspólnota i jej życie mają duże znaczenie dla zaangażowanych w nią członków. Kolejną racją bytu małych grup jest to, że stanowią one miejsce, w którym mogą być zaspokajane potrzeby poszczególnych ludzi (Schemat 3). 


$\begin{array}{ll}\text { KANDYDAT } & \text { KANDYDATKA } \\ \text { CHORALISTA } & \text { CHORALISTKA }\end{array}$

Oaza Dzieci Bożych 1 stopnia

MIN. ŚWIATtA SCHOLISTKA

Oaza Dzieci Bożych 11 stopnia

MIN. KSIĘGI SŁUŻBA DARÓW

Oaza Dzieci Bożych 11 stopnia

MIN. OŁTARZA SŁUŻBA ŁADU.

Oaza Nowego Życia „o” stopnia

PRECENTOR PRECENTORKA

(Kurs lektorski)

EWANGELIZACJA INNA DROGA

Oaza Nowego Życia 1 stopnia O. Niepokalanej 1 stopnia

PIERWSZY ROK DEUTEROKATECHUMENATU

(Min. St. Bożego Komentatorka)

Oaza NŻll st. Oaza Niepokalanej 11 stopnia

DRUGI ROK DEUTEROKATECHUMENATU

(Ceremoniarz Przewodniczka scholi)

Oaza NŻ 111 st. Oaza Niepokalanej 111 st.

TRZECI ROK DEUTEROKATECHUMENATU

(Animator

Animatorka)

\begin{abstract}
Oaza Rodzin 1 stopnia
DOMOWY KOŚClÓŁ 1 .

Oaza Rodzin 11 stopnia

DOMOWY KOŚClÓŁ 2 r.

Oaza Rodzin 111 stopnia

DOMOWY KOŚClÓł 3 r.
\end{abstract}

DIAKONIA
LEKTOR
AKOLITA

(Animator

Animatorka)

Schemat 3. Schemat formacyjny służby liturgicznej i ruch światło - życie. 
Jeśli w otaczającym środowisku społecznym członkowie wspólnoty nie mają takiego miejsca w którym każdy z nich może wyrazić siebie szybko tracą sens uczestnictwa.

Małe grupy mogą także zapewnić realizację pewnych przedsięwzięć, których cała wspólnota nie może w inny sposób zrealizować. Istnieje tendencja, aby myśląc o wspólnocie koncentrować uwagę przede wszystkim na małych grupach. Wiele koncepcji odnowy życia parafialnego polega na zapewnieniu każdemu parafianinowi możliwości uczestnictwa $\mathrm{w}$ jednych $\mathrm{z}$ małych grup. $\mathrm{Z}$ innego punktu widzenia należy zauważyć, że małe grupy same w sobie nie wystarczą. Aby były one zdolne do funkcjonowania przez dłuższy czas, muszą stanowić część większej wspólnoty. Szersza wspólnota stymuluje pracę małej grupy, nie pozwala na stagnację, zapewnia także odpowiednią szerokość spojrzenia na zachodzące w małej grupie zjawiska i procesy (m.in. proces konwersji) (7). Na podstawie uzyskanych wyników hipotezę trzecią zweryfikowano.

Hipoteza czwarta: Obowiązek martyrii (świadectwa), słowem i czynem powoduje przenoszenie przez osoby, które zinternalizowały wartości i cele głoszone przez Ruch, na kierowanie się w życiu codziennym wyniesionymi ze wspólnoty wzorami zachowań i wzajemnych stosunków.

Żywotna wspólnota może wiele dokonać. Ludzie chcą być tam, gdzie coś się dzieje. Kiedy wspólnota jest żywa, w sposób widoczny oddziałuje na swoje otoczenie, posiada też ogromny wpływ na życie towarzyszących ją ludzi. Wiele problemów z jakimi boryka się dzisiaj Kościół wynika z braku żywotności wspólnot podstawowych. Chociaż istnieje wiele czynników, które wpływają na żywotność wspólnoty, najbardziej bezpośrednim źródłem żywotności jest cel wspólnoty i oddanie się członków wspólnoty temu celowi. Przekonywujący wspólny cel może stać się źródłem bardzo efektywnego działania. Brak jednomyślności czy zgody może sparaliżować każdą grupę (wspólnotę). Każda wspólnota pielęgnuje jakiś swój wspólny ideał. Członkowie wspólnoty nie pracują razem aby osiągnąć jakiś szczególny cel, lub zespół celów, lecz fakt, iż istnieje wspólny ideał oznacza, że członkowie wspólnoty umacniają w sobie nawzajem związanie się z pewnym ideałem życia i ten ideał kształtuje życie każdego z nich (8).

Aby zweryfikować powyższą hipotezę należało sięgnąć do założeń programowych Ruchu Oazowego i spisanych, podczas poszczególnych Krajowych Kongregacji Odpowiedzialnych, przejawów samoświadomości Ruchu. Zostały one nazwane charyzmatami Ruchu "Światło - Życie”. Z uwagi na mały stopień świadomości uczestników w niższych grupach formacyjnych, na temat podstawowych wartości i celów Ruchu oraz znajomości dokumentów poszczególnych KKO, analizę ograniczono do członków starszych grup oraz animatorów.

Charyzmat Oazy jako ruchu odnowy Kościoła przeżywają wszyscy badani respondenci. Uważają oni, że Oaza jest i powinna pozostać na statusie ruchu religijno - społecznego.

Podstawowy charyzmat Oazy (Światło - Życie), czyli przekazywanie innym i stosowanie we własnym życiu treści oraz tego duchowego światła, jakie uczestnicy wynoszą ze spotkań w małych grupach, w badanej wspólnocie, jest realizowany w stopniu dostatecznym. Jest na tym polu jeszcze wiele do zrobienia. Zarówno przy akcentowaniu konkretnych zastosowań i ich potrzeby podczas spotkań formacyjnych, jak i sposobów rozliczania osób świadomie postępujących niezgodnie $\mathrm{z}$ zasadami preferowanymi $\mathrm{i}$ głoszonymi przez Ruch.

Charyzmat odnowy liturgii, w badanej wspólnocie, jest realizowany poprzez aktywny udział w niedzielnych Mszach św. i inicjowanie aktywnego udziału w nich poprzez czytanie komentarzy do akcji liturgicznej, układanie intencji modlitwy wiernych, przygotowywanie darów ofiarnych. Przejawem tego charyzmatu jest także umieszczenie w programach 
formacyjnych Oazy Dzieci Bożych, podczas formacji w parafii, podręczników Krajowego Duszpasterstwa Służby Liturgicznej (ministrantów), również prowadzenie szkoły liturgii.

Charyzmat założyciela Ruchu ks. F. Blachnickiego realizuje badana wspólnota poprzez studiowanie i wdrażanie w życie jego wizji Ruchu oraz Kościoła, także przez używanie go jako wzorca osobowego dla animatorów i moderatorów.

Charyzmat Maryjny Ruchu respondenci z badanej wspólnoty realizują poprzez częste nawiązywanie do jej postawy podczas modlitwy. Zgodnie z "Dekalogiem Ruchu" - Maryja jest wzorem Nowego Człowieka, dlatego każdy uczestnik powinien realizować jej postawę służby. Nowy Człowiek powstaje w wyniku procesu konwersji, przy odrzuceniu wszystkiego co poniża ludzką godność (przede wszystkim grzechu).

Kolejnym ważnym charyzmatem, jest w Ruchu charyzmat spotkania. W badanej wspólnocie Oazowej jest on realizowany poprzez organizowanie różnych form spotkań, celem pogłębienia więzi łączącej uczestników, osiągnięcia lepszego zrozumienia, oraz wypracowanie wspólnych form działań. Niebagatelnym walorem wszelkich spotkań jest sam fakt uczestnictwa (partycypacji) w tworzeniu dobra.

Charyzmat małej grupy formacyjnej, jest szczególnie akcentowany podczas odpraw animatorów, z uwagi na ich podstawowe znaczenie w procesie konwersji uczestników. Od właściwie przeprowadzonej formacji w małej grupie zależy przecież stopień i głębokość konwersji poszczególnych uczestników oraz internalizacja przez nich określonych wzorców postępowania i wartości propagowanych przez Ruch.

Charyzmat Domowego Kościoła w badanej wspólnocie nie jest realizowany z uwagi na brak takowej wspólnoty $\mathrm{w}$ parafii. $\mathrm{Z}$ pewną nadzieją spoglądają niektórzy na możliwość adaptowania Rodzin zaangażowanych w pracę Zespołu Synodalnego do formacji w Oazie Rodzin. Wcześniej wielokrotnie, przy nadarzających się okazjach były podejmowane próby utworzenia wspólnoty Domowego Kościoła w parafii. Taka wspólnota zapewniałaby ciągłość formacji oazowej i stosowne perspektywy uczestnikom.

Charyzmat katechumenatu jako drogi formacyjnej $\mathrm{w}$ badanej wspólnocie jest realizowany poprzez organizowanie $\mathrm{i}$ udział $\mathrm{w}$ spotkaniach formacyjnych $\mathrm{w}$ roli uczestnika bądź prowadzącego (animatora). Realizacja tego charyzmatu nie ogranicza się tylko do pracy rocznej lecz sięga także udziału $w$ rekolekcjach zimowych i letnich, które są podsumowaniem roku poprzedniego i wstępem do pracy w roku następnym.

Komplementarnie jest realizowany charyzmat diakonijności Oazy, polegający na zaangażowaniu poszczególnych uczestników w konkretną posługę, choćby najdrobniejszą, na rzecz parafii, bądź wspólnoty Ruchu, czy małej grupy formacyjnej. Zaangażowanie animatorów ma podwójny wymiar. Biorą oni udział $\mathrm{w}$ parafii $\mathrm{w}$ pracach związanych $\mathrm{z}$ formacją katechumenalną, prowadząc spotkania małych grup, jednocześnie biorą udział w pracach wybranych przez siebie diakonii, celem budowania wspólnoty w skali makro.

Charyzmat odnowy Kościoła lokalnego (parafii), jest przez respondentów realizowany jako ukazywanie możliwości działania Ruchu na rzecz parafii, miasta i wcielania tej wizji w życie. Konkretną realizacją może być prowadzona wspólnie z członkami Ruchu Społecznego Katolików Świeckich, inicjatywa "Spotkań Czwartkowych", podczas których kilkunastoosobowe grono stałych uczestników może zapoznawać się z dokumentami Katolickiej Nauki Społecznej, teologii dogmatycznej, moralnej i pastoralnej, jak również z Biblią. Większość z grona uczestników tych spotkań stanowią ludzie dorośli.

Propagowanie charyzmatu wyzwolenia przysparza w badanej wspólnocie najwięcej kłopotów. Powodem tego są pojawiające się wśród uczestników wątpliwości dotyczące realizacji “Drogowskazu 9" (elementu Dekalogu Ruchu), Nowej Kultury. Zakładana jest przy nim całkowita abstynencja od alkoholu, nikotyny, narkotyków jako wyraz ekspiacji i 
szacunku dla drugiej osoby. W ramach omawianej problematyki Ruch w skali ogólnopolskiej podjął inicjatywę Krucjaty Wyzwolenia Człowieka oraz Ruchu Obrony Dziecka Poczętego. W badanej wspólnocie brak jest formalnych agend wspomnianych inicjatyw, jednak do KWC należy według posiadanych informacji ok. $15 \%$ respondentów.

Charyzmat ewangelizacji, jako misji Oazy jest realizowany przede wszystkim poza jej strukturami. Miejscem ewangelizacji indywidualnej jest przede wszystkim grupa rówieśnicza, szkoła, miejsce pracy i rodzina. Czasami nadarza się także okazja do ewangelizowania przypadkowych ludzi napotkanych podczas podróży w pociągu lub innym środku komunikacji. Ewangelizacji grupowej, w badanej wspólnocie, raczej się nie prowadzi.

Każdy z członków badanej wspólnoty stara się przenosić na grunt życia codziennego większą lub mniejszą ilość realizowanych charyzmatów. Dzieje się tak przy podejmowaniu konkretnych dzieł będących wyrazem realizacji określonych, opisanych wyżej charyzmatów. Analiza wyników w Skali Spójności Wspólnoty potwierdza powyższe informacje. Wspólnota jest zatem uznawana jako miejsce dążenia do wspólnego celu przez służbę drugiemu człowiekowi. Służba ta jest wynikiem konwersji, jaka zachodzi w małych grupach i internalizacji wzorców głoszonych przez Ruch. Hipotezę czwartą wobec powyższego uznano za zweryfikowaną.

Hipoteza piata: Konwersja (metanoia) przemiana duchowa jest podstawą budowania wspólnoty. Tylko Nowy Człowiek może tworzyć Nowe Życie, które uobecnia wspólnota (nośnik Nowej Kultury).

Osoby chcące odnawiać jakąś wspólnotę, muszą rozpocząć od własnej przemiany duchowej. Jest to prawdą niezależnie od tego, czy osobą zaangażowaną $w$ odnowę jest duchowny, czy też lider świecki w parafii. Fakt, że osobista odnowa duchowa osób pragnących wspierać odnowę pastoralną jest najwyższy priorytetem, wynika $\mathrm{z}$ dokonanej uprzednio analizy funkcjonowania wspólnot. Wspólnoty tworzą się, jak wspomniano wyżej, dla realizacji określonych celów. Cel - źródło jedności, zwartości wspólnoty, stanowi klucz do rozpoczęcia procesu jej budowania. Troska o cel musi stać na pierwszym miejscu, ponieważ jedynie dzięki temu, co stanowi więź utrzymującą ludzi we wspólnocie, cokolwiek może się zdarzyć. Innymi słowy, jeśli pragniemy odnowy Kościoła, pierwszym krokiem musi być głębsze zwrócenie się ku Bogu. Jeżeli ci, którzy pragną pracować nad odnową Kościoła nie modlą się razem, nie rozważają wspólnie Biblii, jeśli nie mówią innym o Chrystusie i nie stawiają go w swoim życiu na pierwszym miejscu, nie będą efektywni. Ich wysiłki w zbyt małym stopniu będą wyrastały z tego, co stanowi rację istnienia chrześcijaństwa, by móc skłonić ludzi do aktywnego uczestnictwa w Kościele. Punktem wyjścia procesu odnowy jest moment, gdy człowiek lub grupa ludzi powie "To jest warte zachodu". Kiedy ludzie coś posiadają i są o tym przekonani mogą rozpocząc pracę. Drugi krok w procesie odnowy ma miejsce wtedy, gdy zaczynają pojawiać się pierwsze sukcesy. Jest to znak, że wystarczająco już są dojrzali, aby móc skutecznie prowadzić innych do przeżycia takiej odnowy (9).

Podobną zasadę stosuje się $\mathrm{w}$ nadanej wspólnocie. Aby zweryfikować powyższą hipotezę należało sięgnąc do historii wspólnoty i na zasadzie porównań $\mathrm{z}$ obecną sytuacją dokonać analizy wpływu konwersji na proces budowania i rozwoju wspólnoty.

Większość badanej wspólnoty jest zdania, że poprzez swoje uczestnictwo mają możliwość zmiany dotychczas wykonywanych ról społecznych (oczywiście nie wszystkich). Ma to duże znaczenie, $\mathrm{z}$ uwagi na fakt zmian w życiu jednostki i grupy dzięki uczestnictwu we wspólnocie. Nikt nie uważa swoje uczestnictwa we wspólnocie Ruchu za przejaw jakiejś dewiacji, czy słabości wewnętrznej. Przeciwnie, respondenci uważają, że członkostwo we wspólnocie pociąga za sobą deklarację odpowiedzialności za własne słowa i czyny współuczestników tejże wspólnoty. Aktywne i pełne zaangażowanie w przeżywanie 
wspólnoty pomaga w różny sposób poszczególnym jej członkom żyć w społeczeństwie. Przy tym wspólnota różni się od innych grup stopniem wzajemnego zaufania, zrozumienia, jednomyślności i odpowiedzialności oraz stałą wiarą w dążeniu do wyznaczonego celu. Jest ona także służbą miłości wobec drugiego człowieka. W każdej wspólnocie, zwłaszcza religijnej odbywa się proces filtrowania osobowości jej uczestników. Większość uczestników badanej wspólnoty ma tego świadomość i wierzy, że proces ten idzie w pozytywnym dla nich kierunku.

Uczestniczenie we wspólnocie jest wielką szkołą aktywności nie aktywizmu. Filtrowanie osobowości we wspólnocie nie może oczywiście prowadzić i nie prowadzi do utraty własnej tożsamości, chociaż sam proces konwersji wprowadza wiele zmian w postrzeganiu samego siebie i innych. Większość respondentów stwierdziła, że każda wspólnota ma wielką moc, która może służyć do transformacji otaczającego ją świata oraz biorących w niej udział ludzi. Pożądane jest przy tym, by były to transformacje twórcze, rodzące nowe jakości społeczne (emergentne). Wśród respondentów, część jest zdania, że wspólnota niesie ze sobą swoistą kontrolę myślenia. Pozostała część twierdzi, że kontrolą jest objęte raczej postępowanie niż myślenie poszczególnych jednostek. Kontrola ludzkiego myślenia jest mało efektywna (jeżeli w ogóle jest wykonalna). Z hasłem Nowy Człowiek większość uczestników kojarzy postawę naśladowania Chrystusa jako mistrza, przez uczniów. Nowym Człowiekiem jest każdy, którego zasadą życia jest agape - bezinteresowna miłość będąca darem osoby dla osoby. Nowa Wspólnota powstaje przy uczestnictwie Nowych Ludzi, którzy zakończyli podstawowy proces konwersji i starają się żyć ideałami Nowej Kultury. Wzorem takiej wspólnoty jest kościół pierwszych chrześcijan. Nowa Kultura już ze swej nazwy stanowi alternatywę wobec kultury świata dzisiejszego. Propaguje ona postawę wolności od wszelkich zniewoleń, wszystkiego co uwłacza ludzkiej godności, wolności, co ją ogranicza. Nierozerwalnie wiąże się także z postawą trzeźwości w znaczeniu fizycznym i duchowym.

Wszystkie te postawy i nowe jakości społeczne znajdują swoje źródło w metanoi (konwersji), czyli wewnętrznej przemianie duchowej, zmianie nastawienia do czegoś lub kogoś, zmianie sposobu postrzegania świata. Metanoia jest zazwyczaj procesem długotrwałym, ale i przynoszącym odpowiednie, do czasu jego trwania i intensywności przyswajania nowych wzorców, owoce. Bez konwersji nie mogłoby być mowy o Nowym Człowieku, Nowej Wspólnocie, czy Nowej Kulturze. Żaden człowiek nie może w pełni stać się osobą bez wspólnoty z innymi osobami. Wyniki powyższe potwierdzone analizą Skali Spójności Wspólnoty pozwalają na zweryfikowanie hipotezy piątej.

Hipoteza szósta: Pozornie sprzeczne ze sobą zasady równości i jednoosobowego kierownictwa we wspólnocie mają swój sens na zasadzie wzajemnej służby wobec pozostałych jej członków.

Przywódca we wspólnocie musi robić trzy rzeczy. Przede wszystkim musi umieć w taki sposób przedstawić ideał, na którym ma się opierać dana wspólnota, aby ludzie go rozumieli, przyjęli i wzrastali w oddaniu się temu ideałowi. Po drugie: musi umieć zbliżać ludzi do siebie i inspirować ich do nawiązywania między sobą pozytywnych relacji. W końcu musi umieć wprowadzać potrzebne elementy organizacji, aby móc stwierdzić, czy wszystko, czego ludzie potrzebują, aby żyć zgodnie z tym ideałem zostało spełnione. W danym środowisku, czy wspólnocie funkcje jakie spełnia określona osoba w odniesieniu do życia wspólnego, bądź stanowisko jakie zajmuje niekoniecznie są adekwatnym wskaźnikiem jej przywódczego wpływu. Przywódcą we wspólnocie jest ta osoba, która potrafi wywrzeć największy wpływ na ludzi, która skłania ich do przyjęcia określonych postaw i motywuje ich do tworzenia wspólnoty. W pewnym sensie ten rodzaj przywództwa ma charakter funkcjonalny. 
Nadrzędnym kryterium efektywności nie jest tutaj zdolność do wykonywania określonej pracy, ale zdolność zainspirowania ludzi do dobrowolnej pozytywnej odpowiedzi (10).

Dla większości członków badanej wspólnoty równość kojarzy się z posiadaniem tych samych praw i obowiązków przez wszystkich uczestników jakiejś grupy ludzi. Stan taki jest przy tym sytuacją wyjściową. Zaangażowanie się w konkretną posługę na rzecz danej parafii przynosi ze sobą kolejne obowiązki, które są zróżnicowane w zależności od pełnionej posługi. W Ruchu istnieje zasada jednoosobowego kierowania wspólnotą. Przejęta ona została z Kościoła powszechnego. Osoba pełniąca funkcję odpowiedzialnego za konkretną wspólnotę powinna być dobrym organizatorem, znać szczegółowe cele, ku którym będzie prowadzić swoją wspólnotę. Dobrze jest, gdy potrafi ona zgromadzić grono współpracowników, jak swoisty organ doradczy. Zasada jednoosobowego kierownictwa i równości we wspólnocie nie kolidują ze sobą z uwagi na fakt, że kierowanie wspólnotą ma charakter raczej służebny niż władczy. Funkcja odpowiedzialnego jest jeszcze jednym obowiązkiem (okazją do służby), dla konkretnej osoby (zazwyczaj animatora). Z wypowiedzi poszczególnych respondentów wynika, że Ruch przyjmując powyższe zasady, kierował się chęcią nawiązania do tradycji Kościoła, w którym funkcjonuje, na rzecz którego służy z którego się wywodzi. Znajduje w tym przypadku zastosowana zasada "primus inter pares" (pierwszy między równymi), od początku stosowana $\mathrm{w}$ chrześcijaństwie, mająca swój szczególny wyraz w idei papiestwa. Większość wspólnoty jest zdania, że Ruch w parafii nie musi posiadać ukształtowanej diakonii moderacji, powinien ją mieć natomiast na szczeblu rejonu, diecezji i w wyższych strukturach organizacyjnych. Zasada pomocniczności w zarządzaniu wspólnotą ułatwia realizację tego zadania pod warunkiem jasno określonych kompetencji i wymagań od osób, które zobowiązują się pomagać. Podstawową ich cechą powinna być odpowiedzialność za własne słowa i czyny. Podobne zadanie spełnia w procesie budowania wspólnoty i jej rozwoju zasada solidarności (więzi łączącej osoby, które podjęły się realizacji tego samego celu). Solidarność może łączyć członków wspólnoty nie tylko na jej gruncie, ale jeżeli jest prawidłowo internalizowana, powinna mieć miejsce także poza wspólnotą. W wypowiedziach respondentów, zwłaszcza ze starszych grup formacyjnych podkreślany jest fakt, iż moderacja nie jest rządzeniem wspólnotą, a tylko jej ukierunkowywaniem, względnie korygowaniem odchyleń od przyjętych wcześniej celów i zadań. Na temat cytowanej wyżej reguły (primus inter pares) wszyscy uczestnicy badanej wspólnoty uważają, że powinna ona być stosowana w każdej chrześcijańskiej wspólnocie oraz stanowić propozycję także dla wspólnot niechrześcijańskich (niereligijnych).

Animatorom badanej wspólnoty zadano pytanie, czy w procesie animowania (ożywiania) grupy do konkretnej działalności należy patrzeć na uczestników z ich punktu widzenia. Większość animatorów była zdania, że dobrze jest czasem popatrzeć na samego siebie z punktu widzenia uczestnika grupy, aby skorygować w swojej postawie to wszystko, co destabilizuje proces budowania wspólnoty, co rozprasza uczestników.

Odnośnie stosowania zasady równości i jednoosobowego kierownictwa w Kościele powszechnym, przyjmuje się, że mają one swoje zastosowanie we wspomnianej wyżej idei papiestwa oraz soborów i synodów biskupów. Przejawem równości wszystkich członków wspólnoty Kościoła jest rosnąca po Vaticanum II rola wiernych świeckich w życiu Kościoła od strony hierarchicznej. Odzwierciedleniem tego może być fakt, że w Watykańskiej Kongregacji ds. Świeckich na 30 osób, zasiada tam aż 28 osób świeckich. Wiele wątpliwości wzbudziło wśród respondentów stwierdzenie, że równość to traktowanie człowieka na miarę jego możliwości. Większość uważa, że człowiek nie powinien być ograniczany, ani w żaden inny sposób oceniany przez pryzmat własnych możliwości. Nie zawsze one zależą od czynników subiektywnych, dlatego równość we wspólnocie jest w takim przypadku trudna 
do realizacji. Większość respondentów jest także zdania, że pełnienie określonych funkcji we wspólnocie powinno być wyznaczane stopniem zaangażowania w jej działalność każdego $\mathrm{z}$ uczestników. Oczywiście przy takim rozwiązaniu sytuacją komfortową jest, gdy pełnienie takiej czy innej funkcji zbiega się z posiadaniem do jej pełnienia predyspozycji. Z analizy Skali Spójności Wspólnoty wynika, że wiele osób traktuje samą wspólnotę jako przekonanie o wzajemnej odpowiedzialności. Wobec powyższego hipotezę szóstą uznano za zweryfikowaną.

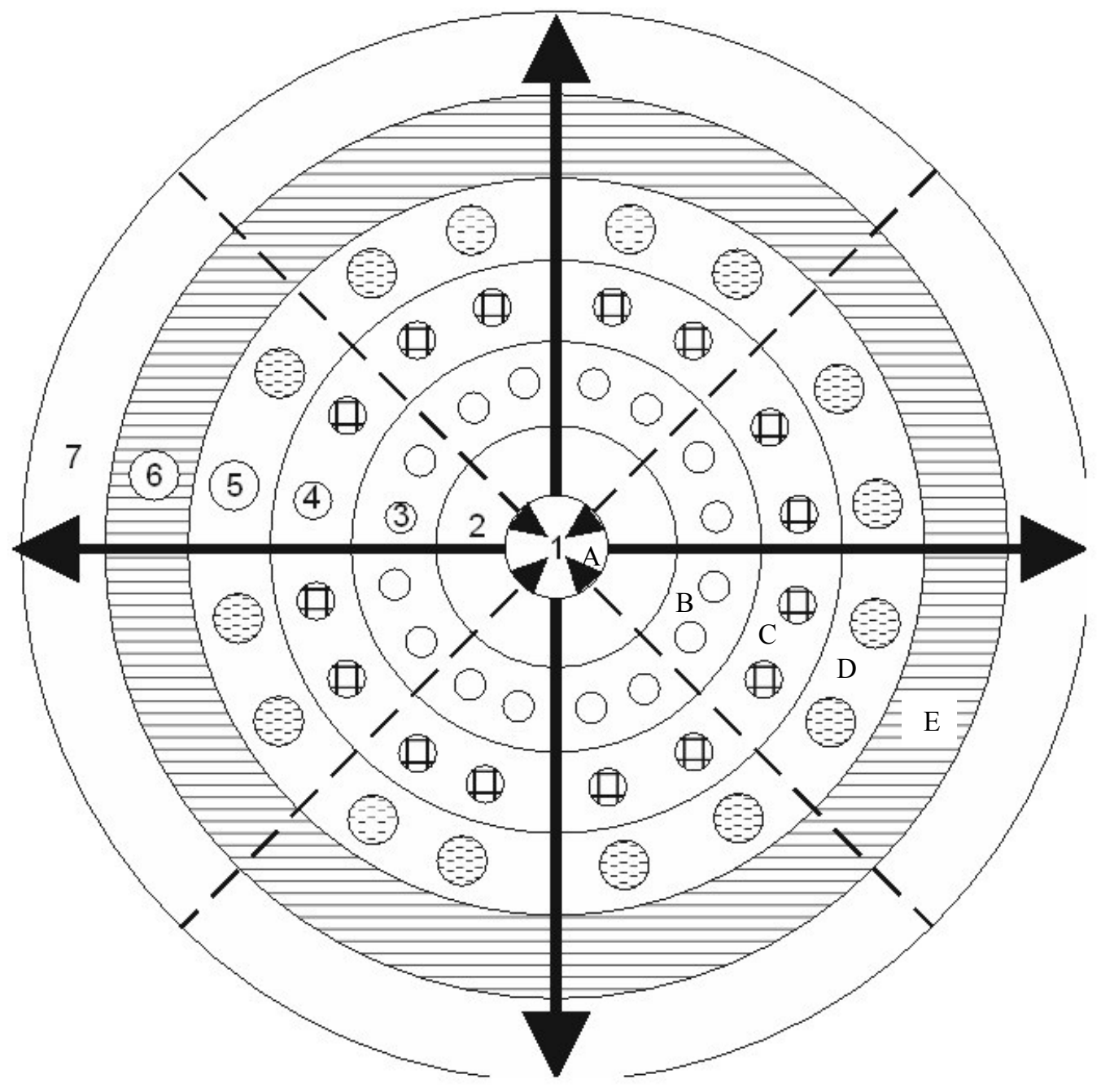

Schemat 4. Parafia jako wspólnota dynamiczna (opr. własne).

A - podmiot duszpasterstwa (pasterz - proboszcz), B - podmioty pomocnicze,

C - wierzący praktykujący (przedmiot duszpasterstwa - owczarnia), D - zdechrystianizowani, E - wpływy dechrystianizacyjne,

1. proboszcz parafii z diakonią stałą, 2. rada apostolska, 3. wspólnoty apostolskie specjalistyczne,

4. wspólnoty apostolskie środowiskowe, 5 . wspólnoty formacyjne (deuterokatechumenalne),

6. wierni praktykujący, 7. niepraktykujący (krąg misyjny),

- - $\longrightarrow$ dynamika misyjna, $\longrightarrow$ dynamika wzrostu parafii. 
Hipoteza siódma: Wspólnota dóbr we wspólnocie następuje, gdy istnieje ona dostatecznie długo, by takie dobra wypracować lub gdy przeobraża się w Świeckie Stowarzyszenie Życia Konsekrowanego (tzw. wspólnotę stałą).

$\mathrm{Na}$ początku swego istnienia każda wspólnota $\mathrm{z}$ wielkim entuzjazmem odnosi się do życia według wzoru błogosławieństw, do ubóstwa, do tego co niesie ze sobą życie. We wspólnotach często próbujemy dotrzeć do tego, co stanowi o istocie naszego życia. Rozmawiamy kto i w jaki sposób trafił do wspólnoty, co w niej znajduje się ożywczego. Dzielenie się wzajemne posiadanymi dobrami i przeżyciami duchowymi jest dla wspólnoty pokarmem odradzającym nadzieję. Dzielenie się słabościami i problemami staje się dla pozostałych osób silniejszym bodźcem niż dzielenie się sukcesami (11).

Wspólnota, która się bogaci, która posiada wszystko co może się jej przydać, izoluje się dlatego, że nie potrzebuje żadnej pomocy. Zasklepia się w sobie i kręgu własnego bogactwa. Wspólnota, która ma wszystko czego potrzebuje, często użytkuje niezgodnie $\mathrm{z}$ przeznaczeniem to, co posiada. Powodowana troską o komfort przestaje odróżniać to co jest luksusem, a co jest rzeczywiście niezbędne. Taka wspólnota bardzo szybko traci też dynamizm w miłości. W ubogiej wspólnocie mamy do czynienia ze wzajemną pomocą i wsparciem finansowym, nie mówiąc o pomocy na zewnątrz. Ubóstwo staje się spoiwem jedności (12).

Niemal wszyscy członkowie badanej wspólnoty stwierdzili, że rzadko zdarza im się "złapać" siebie na tym, że chcą otrzymać więcej niż sami dają z siebie innym. Wszyscy także uważają za konieczność, uczestniczenie w dobroczynno - charytatywnej działalności Kościoła. Konkretnym przejawem było przekazanie odzieży, żywności dla ubogich z parafii jak również ufundowanie kilkunastu paczek dla najuboższych dzieci z okazji świąt Bożego Narodzenia. Uczestnicy skrytykowali jednocześnie podejście, gdy każdy człowiek liczy sam na siebie i nie ma konieczności, by mu pomagać. To prowadzi, jak stwierdzili niektórzy wyłącznie do egoizmu i zamknięcia się na otaczający świat oraz ludzi.

W wypowiedziach respondentów krytycznie odniesiono się do propozycji pomagania innym z uwagi na fakt, że można później liczyć z ich strony na rewanż. Akcentowano, iż nie takie motywy powinny przyświecać czynieniu dobra. O wiele większą satysfakcję daje członkom wspólnoty czynienie dobra, nawet jeśli później nic się z tego nie ma. Wobec powyższego należałoby pomagać nawet tym, którzy z różnych przyczyn nie mogą lub nie chcą się danej wspólnocie odwdzięczyć. O podziale dóbr we wspólnocie, zwłaszcza tych, które mają charakter prywatny (nie osobisty) i wspólnotowy, powinien decydować kierujący wspólnotą. Właścicielem dóbr prywatnych i wspólnotowych jest cała wspólnota, natomiast dysponentem może być każdy jej członek. Posiadanie przez wspólnotę dóbr prywatnych i wspólnotowych stanowi podstawę jej funkcjonowania od strony materialnej. Uczestnicy wspólnoty Ruchu będącej przedmiotem prowadzonych badań uważają, że praktyczna realizacja zasady wspólnoty dóbr jest możliwa niemal wyłącznie we wspólnotach stałych. W innych jest niezmiernie trudna $z$ uwagi na stosunkowo dużą fluktuację uczestników.

Nawiązując do wspólnoty dóbr, nie należy zapominać o obowiązku ewangelicznego ubóstwa, które miałoby zakres wewnętrzny i zewnętrzny. W dobie obecnej pauperyzacji i bezrobocia, zwłaszcza $\mathrm{w}$ terenie na którym funkcjonuje omawiana wspólnota, krytyka ewangelicznego ubóstwa, zwłaszcza w zakresie zewnętrznym nie powinna nastręczać trudności. Respondenci zwrócili też uwagę na zabieganie (troskę) o dobro wspólne, ograniczenie do minimum niepotrzebnych wydatków. Stoją one bowiem w sprzeczności z zasadą ubóstwa i gospodarności. 
Analiza Skali Spójności Wspólnoty przynosi stwierdzenie, że tylko we wspólnocie prawdziwe może być zdanie "wszystko co posiadam jest twoje". Wspólnota staje się więc miejscem, gdzie możemy dzielić się z drugim człowiekiem wszystkim, co posiadamy.

Dotyczy to zarówno strony duchowej, jak i materialnej. Wobec powyższego hipotezę siódmą uznano za zweryfikowaną.

Hipoteza ósma: Działalność “ad intra” we wspólnocie powoduje jej wewnętrzne jednoczenie i wzrost duchowy, natomiast działalność "ad extra" powoduje uznanie w oczach innych i wzrost powołań do życia w niej.

Katolikom świeckim przypada obowiązek bezpośredniego zaangażowania $\mathrm{w}$ budowę kościoła - wspólnoty. Wielu odczytuje to powołanie w różnych ruchach odnowy i organizacjach. W obu przypadkach chodzi o podejmowanie zadań służących celowi duchowemu. Wypełnianie tych zadań nie jest jakimś konkretnym personalnym powołaniem, lecz uprawnia do nich $\mathrm{w}$ sposób bezpośredni i formalny upoważnienie otrzymane od Chrystusa (13).

Służbę jaką dana wspólnota podejmuje realizując określony cel, chce rozwiązać w sposób skuteczny problemy osób i grupy. Równocześnie chce być doświadczeniem formacyjnym dla samej wspólnoty, która chwyta na żywo i uczy się bezinteresownego wymiaru życia. Oddając się bezinteresownie do dyspozycji osób i sytuacji z bezpośredniego i widocznego kręgu wspólnoty, uczy się projektować całe życie jako dar wzrostu. Animator obserwuje uważnie rezultaty działań, ponieważ stanowią one wskaźnik, czy działania te były odpowiednie. Jeszcze uważniej patrzy na procesy, które determinują przemianę w życiu jednostek i grupy. Dostosowuje doświadczenie służby do możliwości grupy. Aby przełożyć ogólną decyzję służenia na gesty i konkretne działania, wspólnota przeprowadza analizę potrzeb, która zakłada ich uwidocznienie, jak również dostrzeżenie współzależności między innymi elementami kontekstu. Po przeprowadzeniu analizy potrzeb wspólnota dyskutuje na temat celów, które powinna i może osiągnąć. Kolejnym zadaniem, przed przejściem do działania i w czasie kiedy ono się dokonuje jest skoncentrowanie się na stylu w jakim wspólnota pragnie przeżywać swoją służbę. Po tym wspólnota decyduje o metodzie działania, która jest najbardziej optymalna do osiągnięcia wcześniej ustalonego celu (14).

Działalność wspólnoty jako całości jest podzielona na dwa sektory (ad intra i ad extra). Wyrazem realizacji tych dwóch sektorów są zadania jakie stoją przed poszczególnymi diakoniami (posługami). Aby grupę móc nazwać diakonią, musi ona spełniać szereg wymagań formalnych. Należy do nich zebranie odpowiedniej grupy ludzi deklarujących chęć stałego działania zgodnie z celami danej diakonii. Diakonia prowadzi własne spotkania formacyjne, niezależnie od prowadzonej formacji deuterokatechumenalnej. Ze spotkań danej diakonii powinny wynikać konkretne zastosowania jej celów w życiu poszczególnych uczestników.

Do diakonii zajmujących się działalnością wewnątrz wspólnoty (ad intra) zaliczane są: diakonia moderacji, jedności, deuterokatechumenatu, formacji diakonii, świadectwa, wspólnoty lokalnej, Domowego Kościoła, środków przekazu, środków materialnych, informacji, transportu. Ich celem jest budowanie i zacieśnianie więzi wspólnotowych wśród uczestników poprzez podejmowanie inicjatyw statutowych. Przykładowo diakonia moderacji czuwa nad realizacją zadań całej wspólnoty, ukierunkowując jej działania. Diakonia jedności sprawuje nadzór nad realizacją zasadniczego celu przez różne posługi w jednej wspólnocie. Diakonia formacji diakonii zajmuje się permanentną formacją animatorów, czyli uczestników wspólnoty Ruchu po zakończonej formacji podstawowej(deuterokatechumenalnej). Diakonia świadectwa zajmuje się upowszechnianiem słowa mówionego wewnątrz wspólnoty, ściśle przy tym współpracując $\mathrm{z}$ diakonią ewangelizacji, mającą podobne zadania na zewnątrz 
wspólnoty. Diakonia środków przekazu i informacji czuwają nad właściwym obiegiem wszelkich informacji w obie strony we wspólnocie i poza nią. Diakonia środków materialnych zajmuje się właściwą gospodarką środków wypracowanych przez wspólnotę, zabezpiecza materialną stronę funkcjonowania wspólnoty. Poprzez pomnażanie dóbr wspiera ona także podejmowane przez wspólnotę dzieła i akcje członków innych diakonii. Diakonia Domowego Kościoła czuwa nad prawidłowym przebiegiem formacji w kręgach Oazy Rodzin.

W omawianej wspólnocie nie istnieją formalnie wykształcone diakonie. Ich miejsca zajmują doraźnie kształtowane grupy celowe, spełniające tylko niektóre z funkcji diakonii. Powodem takiego stanu rzeczy jest odchodzenie ze wspólnoty uczestników po zakończonej formacji podstawowej z uwagi na zbieżność z ukończeniem szkoły średniej. Większość z tych osób wyjeżdża do ośrodków wielkomiejskich celem kontynuowania nauki w szkołach wyższych, policealnych i pomaturalnych.

Drugi sektor zaangażowania się członków Ruchu reprezentują diakonie działające na zewnątrz (ad extra).

Należą do nich: diakonia modlitwy, wyzwolenia, samarytańska, liturgiczna, ewangelizacji, oaz rekolekcyjnych i narodu. Każda z nich ma jasno sprecyzowany program i wypracowane formy działania. Diakonia modlitwy odpowiada za życie modlitewne nie tylko w samej wspólnocie Ruchu, ale też inicjuje spotkania modlitewne i poświęcone odnowie życia duchowego dla całej parafii. Członkiem diakonii modlitwy zostaje się po rekolekcjach KODAM (Kurs Oazowy dla Animatorów Modlitwy). Diakonia wyzwolenia funkcjonuje poprzez swoje agendy - Krucjatę Wyzwolenia Człowieka, Ruch Obrony Dziecka Poczętego, system rekolekcji, spotkania w parafiach i wydawanie własnego pisma "Eleuteria". Stanowi ona propozycję pewnej postawy dla osób także spoza Ruchu. Do diakonii pozwolenia można wejść po rekolekcjach ORDW (Oaza Rekolekcyjna Diakonii Wyzwolenia). Diakonia samarytańska zajmuje się udzielaniem wsparcia w sprawach materialnych i duchowych osobom potrzebującym. Diakonia liturgiczna czuwa nad właściwym realizowaniem wskazań soborowej odnowy liturgii, zwłaszcza podczas Mszy św. i nabożeństw z udziałem osób z Ruchu. Współpracuje na tym polu z Duszpasterstwem Służby Liturgicznej, którego niegdyś (przed 1988r,) stanowiła integralną część. Do diakonii można należeć po rekolekcjach KODAL (Kurs Oazowy dla Animatorów Liturgicznych). Diakonia ewangelizacji, podejmująca wezwanie papieża do wtórnej Ewangelizacji świata przed rokiem dwutysięcznym, w wielu miastach Polski organizuje spotkania, akcje ewangelizacyjne. Przykładem tego może być choćby "Marsz dla Jezusa" od kilku lat przeprowadzany w maju w większych miastach Polski. Jest to akcja o charakterze ekumenicznym. Diakonia ewangelizacji stara się głosić dobrą nowinę wszędzie i wszystkim. Na tym polu stale współpracuje z diakonią modlitwy. Członkiem diakonii ewangelizacji można zostać po ORAE (Oaza Rekolekcyjna Animatorów Ewangelizacji).

Diakonia Oaz Rekolekcyjnych jest powoływana dla zapewnienia właściwej organizacji rekolekcji oazowych, zarówno letnich jak i zimowych. Działalność Diakonii narodu polega na realizowaniu wizji angażowania się osób świeckich w sprawy społeczne i polityczne zgodnie z Katolicką Nauką Społeczną. Poprzez wydawanie czasopisma "Emaus", prowadzenie Szkoły Liderów Katolickich oraz Wyższej Szkoły Zarządzania i Przedsiębiorczości w Warszawie, swoje agendy - Krucjatę Wyzwolenia Człowieka, Ruch Obrony Dziecka Poczętego, system rekolekcji, spotkania w parafiach i wydawanie własnego pisma "Eleuteria". Stanowi ona propozycję pewnej postawy dla osób także spoza Ruchu. Do diakonii pozwolenia można wejść po rekolekcjach ORDW (Oaza Rekolekcyjna Diakonii Wyzwolenia). Diakonia samarytańska zajmuje się udzielaniem wsparcia w sprawach 
materialnych i duchowych osobom potrzebującym. Diakonia liturgiczna czuwa nad właściwym realizowaniem wskazań soborowej odnowy liturgii, zwłaszcza podczas Mszy św. i nabożeństw z udziałem osób z Ruchu. Współpracuje na tym polu z Duszpasterstwem Służby Liturgicznej, którego niegdyś (przed 1988r,) stanowiła integralną część. Do diakonii można należeć po rekolekcjach KODAL (Kurs Oazowy dla Animatorów Liturgicznych). Diakonia ewangelizacji, podejmująca wezwanie papieża do wtórnej Ewangelizacji świata przed rokiem dwutysięcznym, w wielu miastach Polski organizuje spotkania, akcje ewangelizacyjne. Przykładem tego może być choćby "Marsz dla Jezusa" od kilku lat przeprowadzany $\mathrm{w}$ maju $\mathrm{w}$ większych miastach Polski. Jest to akcja o charakterze ekumenicznym. Diakonia ewangelizacji stara się głosić dobrą nowinę wszędzie i wszystkim. $\mathrm{Na}$ tym polu stale współpracuje z diakonią modlitwy. Członkiem diakonii ewangelizacji można zostać po ORAE (Oaza Rekolekcyjna Animatorów Ewangelizacji).

Diakonia Oaz Rekolekcyjnych jest powoływana dla zapewnienia właściwej organizacji rekolekcji oazowych, zarówno letnich jak i zimowych. Działalność Diakonii narodu polega na realizowaniu wizji angażowania się osób świeckich w sprawy społeczne i polityczne zgodnie z Katolicką Nauką Społeczną. Poprzez wydawanie czasopisma "Emaus", prowadzenie Szkoły Liderów Katolickich oraz Wyższej Szkoły Zarządzania i Przedsiębiorczości w Warszawie, Instytucje totalne analizowane przez E. Goffmana są prototypem takich integrujących miejsc (m.in. wspólnot), gdzie wprowadzona jest jednoczesność działań aktorów, ich obserwowalność, dyscyplina łamiąca autonomię czynów i dyskrecję osoby (17).

Wspólnota może być miejscem dla osób, które dobrowolnie wycofały się z życia czynnego, stając się ośrodkiem kontemplacji religijnej i innej. Nie do końca znajduje to potwierdzenie w przypadku wspólnoty Ruchu Oazowego. Uczestnicy badanej wspólnoty stwierdzają, że żaden z nich nie wycofał się z życia czynnego w otaczającym świecie i na razie nie ma takiego zamiaru. Oprócz pracy formacyjnej i w strukturach quasidiakonijnych respondenci postrzegają badaną wspólnotę jako miejsce przede wszystkim relaksu (zabawy), nie istnieje wspólnota zamieszkania i wspólnej pracy zarobkowej. Takie wspólnoty istnieją w Ruchu zazwyczaj na szczeblu diecezji, przybierając formę Świeckich Instytutów Życia Konsekrowanego. W badanej wspólnocie nie potwierdza się jedna $\mathrm{z}$ naczelnych zasad działania instytucji totalnych, czyli podporządkowanie wszystkiego co się w niej dzieje, jednej osobie. Nie można także powiedzieć, by wszystko co dzieje się we wspólnocie było ściśle zaplanowane, by nie istniały od przyjętych planów żadne odstępstwa. Niektórzy uczestnicy stwierdzali, że nic nie jest ściśle zaplanowane. W każdym przedsięwzięciu pozostawia się dość duży margines spontaniczności, celem uwzględnienia zmian zachodzących w toku realizacji danego przedsięwzięcia.

Animatorzy badanej wspólnoty Ruchu starają się realizować przewidziany wcześniej plan działalności wspólnoty, podchodzą jednak do niego po uwzględnieniu odmienności poszczególnych osób. Jest to zgodne z zasadą personalizmu w kontaktach międzyosobowych.

Nieprawdziwe jest twierdzenie, że zaspokajanie wszelkich potrzeb we wspólnocie odbywa się na drodze biurokratycznej organizacji. Po raz kolejny nie znajduje tutaj potwierdzenia jedna z zasad funkcjonowania instytucji totalnych. Uczestnicy podają także, że nie odczuwają jakiegokolwiek ograniczenia kontaktów ze światem zewnętrznym przez swoje zaangażowanie w życie wspólnoty. Co najwyżej ograniczenia mogą wynikać z własnych fobii uczestników.

O wiele poważniejsze rozterki wśród uczestników wzbudziło rozstrzygnięcie kwestii, czy rekolekcje typu zamkniętego, jakie są propagowane przez Ruch Oazowy, nie są 
przejawem instytucji totalnej. Większość uczestników, a nawet niektórzy animatorzy stwierdzili, że wiele cech rekolekcji na to wskazuje.

Przykładem może być stosunkowo duże odizolowanie od świata, poddanie regulaminowi ośrodka rekolekcyjnego, podporządkowanie uczestników animatorom, spełniony też jest wymóg wspólnego zamieszkania, pracy i zabawy.

Rekolekcje nie spełniają jednak innych cech instytucji totalnej, takich jak poddanie się wpływom biurokratycznej organizacji, ścisłemu zaplanowaniu wszystkich zajęć bez możliwości odstępstw.

W badanej wspólnocie w zasadzie nie istnieje skodyfikowany system przywilejów, lub kar. Obowiązujące zasady stosowane przy weryfikacji uczestników i ich posługi we wspólnocie, wynikają raczej ze stopnia ich zaangażowania w jej życie.

Metanoia (konwersja) przeżywana we wspólnocie ma skutki dalekosiężne, wykraczające poza jej struktury. Tak być powinno i przy prawidłowo prowadzonej formacji deuterokatechumenalnej, tak jest. We wspólnocie będącej obiektem badań nikt nie ogranicza możliwości wybory drogi życiowej, jako realizacji odczytywanego osobistego powołania.

Ważną sprawą, zwłaszcza w obecnych czasach, jest umiejętność odróżniania wspólnoty kościelnej od sekty religijnej.

Podstawową kwestią jak odróżniać wspólnotę od sekty jest fakt łączności z kościołem hierarchicznym pierwszej, natomiast krytykowanie wszystkiego, co kojarzy się z hierarchią w przypadku drugiej grupy.

Przez łączność z Kościołem hierarchicznym mam na myśli przede wszystkim łączność z przedstawicielami kościoła lokalnego. Wśród większości sekt panuje ortodoksja i fanatyzm związany z wyznawaniem przyjętej doktryny. W kościele pojmowanym jako wspólnota, takie zjawisko w okresie posoborowym należy raczej do rzadkości.

Większość uczestników wstępowało do badanej wspólnoty raczej z niską świadomością jej celów, jednak z motywacją wzrostu w wierze, chęcią aktywnego i bardziej świadomego przeżywania własnej wiary. Żaden z uczestników nie czuł się też nigdy zniewolony będąc we wspólnocie.

Sama przynależność do wspólnoty niesie za sobą bardziej poczucie wyzwolenia niż zniewolenia. W przypadku przebywania poza wspólnotą przez krótszy lub dłuższy czas, większość uczestników stara się utrzymywać z nią kontakt korespondencyjny, jest to także okazja do zbierania opinii o wspólnocie od osób spoza niej.

Do bardziej duchowych elementów więzi ze wspólnotą zaliczyć można modlitwy w jej intencji.

Analiza Skali Spójności Wspólnoty pozwala na stwierdzenie, że nie jest możliwe utworzenie i funkcjonowanie wspólnoty poprzez ustanowienie odpowiednich kar i nagród. Fizyczne oddalenie poza wspólnotę jest czasowo konieczne, z uwagi na potrzebę analizy własnego zaangażowania, z pewnej perspektywy. Ważnym stwierdzeniem jest też zdanie, że struktury wspólnoty powinny być jasno określone, ale jednocześnie elastyczne i zmienne, w zależności od potrzeb. Powyższe ustalenia pozwalają na zweryfikowanie hipotezy dziewiątej.

Hipoteza dziesiata: $\mathrm{O}$ ile utworzenie wspólnoty o zasięgu mezostruktury byłoby możliwe na gruncie społecznym, o tyle stworzenie wspólnoty o zasięgu makrostruktury jest możliwe tylko na gruncie religijnym.

Religia pełni nie tylko funkcje psychologiczne jak źródło pomocy w trudnych chwilach życiowych, ale jest przewodniczką w szukaniu nowego ładu moralnego w wymiarach globalnych. Dostrzeganie całościowej roli religii oznacza przejście od mikrofunkcji do makrofunkcji i wyraża przymierze religii z ludzkością. Człowiek szuka jakiejś jednej uniwersalnej struktury (wspólnoty), która byłaby w stanie wytłumaczyć wspólne podłoże dla 
różnych przejawów ludzkiej działalności. Ludzkość potrafi przetrwać w swej masie i zapewni sobie przyszłość tylko wtedy, gdy zdoła upowszechnić postawy określone jako etos solidarności, jako świadomość wspólnoty losów rodziny ludzkiej (18).

Decydujące znaczenie dla poprawnego zdefiniowania "różnicy, która jednak nie dzieli”, ma wprowadzenie obok kategorii Kościoła i świata teologicznej kategorii Królestwa. Związek zachodzący między nimi, który wyraża tyle rzeczywistości, pozwala pogłębić soborową teologię laikatu. Teologia ta rozważana jedynie w kategoriach Kościoła i świata może doprowadzić do rozdziału różnych sposobów przeżywania wspólnoty (19).

Wspólnoty zrzeszają się według wielorakich sposobów i zainteresowań oraz w różnych okresach, które nie wykluczają się między sobą, ale raczej nawzajem przywołują i oddziałują na siebie na rozmaite sposoby.

Pierwszym zakresem, w którym wspólnoty łączą się w szersze struktury jest wspólnota wychowawcza. Różnorodność znajduje w środowisku wychowawczym możliwość uczestnictwa i dialogu oraz doświadcza, w opracowywaniu, realizacji i weryfikacji projektu wychowawczo - duszpasterskiego. Wszystkie wspólnoty, niezależnie od tego jaka jest ich nazwa i cele, oddziałują wzajemnie, aby się ubogacić, stworzyć klimat kulturalnie żywy i zaangażowany.

Drugim zakresem łączenia się wspólnot w szersze struktury jest własne terytorium $\mathrm{i}$ Kościół lokalny (tutaj rozumiany jako diecezja). Wszystkie wspólnoty niezależnie od tego jakie jest ich podstawowe zainteresowanie, czują się uczestnikami wysiłków wspólnoty ludzkiej, w stawianiu czoła problemom, które wynurzają się z konkretnej sytuacji danego terytorium. W różnych specyficznych formach posługi potrafią znaleźć momenty porównawcze i wspólne kryteria, aby zweryfikować ich wpływ na daną wspólnotę.

Trzecim zakresem łączenia się wspólnot w struktury szersze są stowarzyszenia na poziomie narodowym i międzynarodowym. Specyficzne cele społeczne, kulturalne i religijne, szeroka organizacja z różnymi strukturami wspierającymi, umiejętność pośredniczenia oraz reprezentowania $\mathrm{w}$ miejscach $\mathrm{w}$ których opracowuje się narzędzia polityki społecznej, to elementy dostarczające połączeń na szeroką skalę (20).

W świecie tak zmaterializowanym i tak indywidualistycznym jak dzisiaj, wobec rozpadania się tkanki rodziny, upadających tradycji religijnych, społecznych i rodzinnych, z pewnością coraz silniejsze będzie pragnienie życia wspólnotowego. Dzięki małym wspólnotom jest możliwe spajanie różnorodności w jedność. Ewangelizacja całej ziemi nie przyjdzie dzięki technice, inteligencji pastoralnej, czy gorliwości apostolskiej. Przynieść ją może tylko wspólnota (21).

Przez ostatnich dwadzieścia wieków Kościół tworzył wspaniałe dzieło zjednoczenia i umocnienia ludzkości. Nieprawdą jest, że chrześcijaństwo niczego nie dokonało. dzisiejszy świat potrzebuje zjednoczenia, potrzebuje wspólnoty. Wierni w sąsiadujących krajach czasami nie potrafią wspólnie żyć. Jeśli człowiek jest wierzącym, powinien posiadać postawę uniwersalną, okazywać miłość do własnej Ojczyzny, ale ponadto do całego świata, dla wszystkich ludzi (22).

Większość uczestników badanej wspólnoty nie miała trudności z określeniem, co można nazwać mianem makrostruktury społecznej. Określenia te pokrywały się w zasadzie z podanymi wcześniej definicjami. Do wielkich struktur społecznych uczestnicy zaliczyli kościoły, Organizację Narodów Zjednoczonych i jej agendy, sojusze wojskowe i układy ekonomiczne o zasięgu światowym bądź kontynentalnym. Przy podawaniu przykładu kościołów, w kilku przypadkach padło zastrzeżenie, iż chodzi o te, które swym zasięgiem obejmują przynajmniej jeden kontynent. Większość uczestników jest zdania, że z przywołanych wyżej przykładów makrostruktur jedynie kościoły mogą spełniać zadanie 
tworzenia wspólnoty. Dzieje się tak dlatego, iż kościół ze swojej natury jest wspólnotą wzajemnie uzupełniających się wspólnot lokalnych, diecezjalnych, obejmujących całe państwa i kontynenty. W przypadku Kościoła Rzymskokatolickiego, oddziaływaniem objęty jest cały świat. Poza tym kościołem rzadko który z pozostałych prowadzi zakrojoną na tak szeroką skalę działalność ewangelizatorsko - misyjną. Prawie połowa uczestników badanej wspólnoty była przynajmniej na jednej Mszy św. odprawianej przez papieża, podczas jego pielgrzymek do Polski. Odczucia wszystkich uczestników takiej Mszy są różnorodne. Coś co ich łączy to poczucie wielkiej wspólnoty, dzięki człowiekowi, którego poważa cały świat, który potrafi nawiązać kontakt z każdym, który potrafi budować wspólnotę wszędzie tam, gdzie się pojawia, zawsze jest przy tym rozumiany. Kościół powszechny znajduje się aktualnie w trakcie asymilacji myśli Vaticanum II.

Powoli, poprzez powstawanie różnorodnych małych wspólnot utrzymujących stały kontakt z kościołem hierarchicznym na szczeblu lokalnym, kościół powszechny staje się także wspólnotą.

W wielkich zbiorowościach ludzkich, budowanie wspólnoty opiera się przede wszystkim na dążeniu do wspólnej realizacji wyznaczonego celu, wzajemnej pomocy i charyzmatycznej osobowości przywódcy. Dowodem na to może być rozwój Ruchu Oazowego od nieśmiałych początków w latach pięćdziesiątych, do ogromnego wzrostu ilościowego w drugiej połowie lat siedemdziesiątych i latach osiemdziesiątych.

Respondenci stwierdzili, że na Mszach św. odprawianych przez papieża zadziwia ich umiejętność trafiania do serc tylu różnych i odmiennie myślących ludzi, oraz tworzenie jedności z różnorodności. Bardzo przy tym cenili homilie i kazania głoszone przez papieża.

Podobnie jak wspólnota nie może istnieć bez swoich struktur, tak i kościół nie może istnieć bez wewnętrznej organizacji (hierarchii). Podobnie nie można być człowiekiem religijnym, bez uznawania i przebywania w tej czy innej wspólnocie kościelnej.

Tabela 2. Rozwój liczebny Oaz.

\begin{tabular}{|c|c|c|}
\hline Rok & Ilość grup & Ilość uczestników \\
\hline 1951 & 2 & 210 \\
\hline 1955 & 1 & 100 \\
\hline 1960 & 8 & 450 \\
\hline 1969 & 311 & 700 \\
\hline 1974 & 1.400 & 9.500 \\
\hline 1979 & 2.200 & 40.000 \\
\hline 1984 & 2.500 & 64.000 \\
\hline 1989 & 2.600 & 77.000 \\
\hline 1994 & & 63.000 \\
\hline
\end{tabular}

źródło: opracowanie własne 
Wszyscy respondenci podają, że uważają za konieczne istnienie państwa Watykańskiego, jako politycznego reprezentanta interesów niemałej w skali świata społeczności katolików.

Większość uczestników jest zdania, że w Polsce jest aktualnie wystarczająca, w stosunku do liczby mieszkańców, liczba kościołów. Pozostają jednak kwestie ich właściwego i maksymalnego wykorzystywania. Na pytanie dotyczące roli soborów i synodów biskupów, respondenci zazwyczaj udzielali odpowiedzi, że poprzez nie wzrasta poczucie świadomości wiernych jako członków wielkiej wspólnoty Kościoła powszechnego.

W badanej parafii, o czym wspomniano wyżej istnieje od dwóch lat agenda działającego sesyjnie Synodu Plenarnego Prowincji Polskiej. Spotkania tej grupy odbywają się w różnych miejscowościach dekanatu na terenie którego leży parafia.

Struktury są konieczne do funkcjonowania każdej wspólnoty niezależnie od jej zasięgu. Przy budowaniu wspólnoty typu religijnego na szczeblu makrostruktury, jak i na niższych szczeblach jest wykorzystywany nadprzyrodzony aspekt wspólnoty $\mathrm{z}$ istotą najwyższą (Bogiem). Analiza Skali Spójności Wspólnoty potwierdza powyższe ustalenia. W związku z tym hipotezę dziesiątą zweryfikowano.

Hipoteza jedenasta: Do czynników destabilizujących wspólnoty należą przede wszystkim: brak przebojowości w działaniu na zewnątrz, brak całkowitej internalizacji postaw propagowanych przez wspólnotę u niektórych uczestników, niezakończony proces konwersji, wskutek wadliwej formacji podstawowej. Niebagatelną rolę odgrywa także egoizm w postawach niektórych członków wspólnoty i ich zły wpływ na pozostałych członków wspólnoty.

Doniosłą rolę w procesach integracji odgrywa ruchliwość społeczna członków danej wspólnoty. Nadmierna ruchliwość członków w danej wspólnocie sprzyja dezintegracji normatywnej, ponieważ członkowie tej grupy nie są w stanie adaptować się do wzorów zachowań i norm uznawanych w danej wspólnocie za obowiązujące.

Przelotne uczestnictwo w grupie uniemożliwia jej stworzenie życia grupowego i nie motywuje we właściwy sposób do zaangażowania się w nie. Trudno jest jednostce wiązać się $\mathrm{z}$ daną wspólnotą, ponieważ nie stanowi ona układu odniesienia porównawczego, ani normatywnego, które oddziaływałoby stabilizująco na owe "wędrujące" jednostki. Również instytucje danej wspólnoty nie mogą właściwie oddziaływać na takich, ciągle zmieniających się uczestników. Wszystko to czyni jednostki podatnymi na zachowania dewiacyjne (23).

Jako kolejny czynnik warunkujący dezintegrację wymienia się heterogeniczność i złożoność. Im bardziej wzrasta heterogeniczność członków danej grupy oraz im bardziej wzrasta jej złożoność, tym bardziej wzrasta dezintegracja normatywna grupy. W grupach niejednorodnych i złożonych trudniej osiągnąć unifikację zachowań ludzkich oraz zgodność wartości i norm postępowania $\mathrm{z}$ obowiązującymi we wspólnocie, gdy w takich grupach instytucje grupowe nie są w stanie oddziaływać w pełni skutecznie na zachowania jednostek.

Ważnym czynnikiem wpływającym na stan i stopień dezintegracji wspólnoty jest konflikt ról. Ma on dwojaki charakter. Od pojęcia roli jako zestawu ról związanego z określoną pozycją należy odróżnić pojęcie i zjawisko ról złożonych i kompleksów ról (24).

$\mathrm{Na}$ żadną wspólnotę nie może pozytywnie wpływać permanentna rotacja jej uczestników. W badanej wspólnocie Ruchu każdego roku pojawia się od dziesięciu do dwudziestu nowych uczestników i tyle też odchodzi, po krótszym lub dłuższym okresie formacji wewnątrz niej. Odchodzenie uczestników, zwłaszcza z wyższych stopni formacji podstawowej negatywnie wpływa na motywację do kontynuowania dalszej formacji wśród pozostałych uczestników. Rzadko przy tym zdarzają się przypadki, by uczestnik, który opuścił wspólnotę, powrócił do niej, celem kontynuowania formacji. 
Mała aktywność członków wspólnoty w działalności ad extra (w stosunku do potrzeb) powoduje, że Ruch jako wspólnota działająca w parafii i na jej rzecz pozostaje mało zauważalny. Takie traktowanie wspólnoty i jej uczestników nie może, i nie wpływa zachęcająco na członków badanej wspólnoty. Podejmowanie działań celem zmiany wizerunku wspólnoty w oczach opinii publicznej, przynajmniej na szczeblu lokalnym, jest jak na razie procesem długotrwałym lecz, jak wszyscy respondenci twierdzą, przynoszącym wymierne efekty. Przykładem działań podejmowanych $\mathrm{w}$ ramach integracji wspólnoty $\mathrm{z}$ parafią jest wydawanie miesięcznika "Pustynia", w którym pojawiają się artykuły traktujące o wydarzeniach z życia całej parafii, nie tylko wspólnoty Ruchu.

Z wypowiedzi członków wspólnoty wynika, że nie wszyscy i nie do końca utożsamiają się z jej duchowością oraz propozycją struktur. Na przeszkodzie w tym przypadku staje wiek uczestników, ich podporządkowanie rodzicom, stosunkowo duży wpływ grupy rówieśniczej na proces internalizacji określonych wartości i prawd.

Nie wszyscy członkowie wspólnoty znają do końca jej cele, nie mówiąc już o całkowitym z nimi utożsamianiu się. Pomimo tych wszystkich niedoskonałości, elementem przeciągającym, staje się możliwość spotkania z drugim człowiekiem, któremu można zaufać, zwierzyć się, który udzieli dobrej rady, zaspokojona zostaje także potrzeba afiliacji. $\mathrm{Na}$ fakt całkowitej akceptacji prezentowanych przez wspólnotę Ruchu wartości i celów, ma wpływ także i to, że uczestnicy dokładnie mogą się zapoznać z historią Ruchu i jego podstawowymi założeniami podczas formacji Kursu dla Animatorów (KODA).

Jest to jeden $\mathrm{z}$ ostatnich etapów formacji podstawowej, przypadający zazwyczaj na wiek 18 lat. Oczywiście główne cele działalności wspólnoty są wyjaśniane już podczas wstępnych spotkań dla osób rozpoczynających formację. Daleko tu jednak do ukazania całościowej wizji Ruchu.

Z uwagi na to, że proces konwersji we wspólnocie musi być traktowany indywidualnie, ponieważ różny jest stopień jego zaawansowania u poszczególnych uczestników, tylko niektórych można nazwać Nowym Człowiekiem na miarę wzorca proponowanego przez wspólnotę. Dotyczy to zwłaszcza tych, którzy potrafili proponowane wartości i normy zinternalizować w stopniu większym niż pozostali.

Z wypowiedzi większości członków badanej wspólnoty wynika jednak, że uważają oni miejsce, w którym się spotykają za Nową Wspólnotę na pustyni duchowej dzisiejszego świata. Staje się ona prawdziwą Oazą, pełną “życiodajnej wody duchowej”. Nie przeszkadza temu fakt, że nie wszyscy uczestnicy zasługują na miano Nowego Człowieka. Duży nacisk kładzie się we wspólnocie na znajomość zasad Nowej Kultury i ich przestrzegania.

Z poglądem, że egoizm nie licuje z uczestnictwem w jakiejkolwiek wspólnocie zgodzili się wszyscy uczestnicy badanej wspólnoty. Pomimo zapoznania się (dość szczegółowego), z zasadami Nowej Kultury, respondenci zauważyli, że żaden z nich, jak też wspólnota jako całość nie wypełnia do końca swoich zadań ewangelizacyjnych w zakresie krzewienia Nowej Kultury.

Za przejaw patologii społecznych respondenci uważają takie zjawiska i procesy jak alkoholizm, nikotynizm, narkomania, rozwody, prostytucja, aborcja, przestępczość, bezrobocie, brak autorytetów (upadek wcześniej istniejących). Aby się temu przeciwstawić Ruch wypracował alternatywny program oparty na autorytecie Kościoła i nauce zawartej w Ewangelii. F. Blachnicki, założyciel Ruchu Oazowego, wielokrotnie przypominał, że nie jest to program łatwy w realizacji, ale konieczny dla właściwego duchowego wzrostu. Program ten został nazwany “Ad Christum Redemptorem” z uwagi na wiele odniesień do pierwszej encykliki Jana Pawła II. 
Wpływ bezrobocia na wspólnotę jest duży. Dopiero konkretny program pomocy dla ludzi bezrobotnych ze strony wspólnoty parafialnej (także Ruchu) może pozwolić podnieść jej autorytet w oczach zwłaszcza ludzi bezrobotnych. Wielu członków badanej wspólnoty pochodzi $\mathrm{z}$ rodzin, $\mathrm{w}$ których przynajmniej jeden $\mathrm{z}$ rodziców pobiera zasiłek dla bezrobotnych.

Alkoholizm i nikotynizm oraz narkomania są nałogami zniewalającymi człowieka, zabierającymi mu wolną wolę. Wspólnota Ruchu w myśl ideałów Nowej Kultury, wszystkimi dostępnymi sposobami powinna się temu procesowi przeciwstawić. W badanej parafii uczestnictwo w Ruchu Oazowym nie jest, jak stwierdzili wcześniej respondenci, miejscem zniewolenia, lecz miejscem, gdzie mogą sobie uświadomić, iż człowiek został stworzony do wolności. Do pozytywnych elementów w procesie budowania wspólnoty zaliczyć można organizowanie imprez o zasięgu całego miasta (parafii). W ostatnim okresie czasu jest ich niepomiernie mało, przez co sam proces budowania wspólnoty wiele traci.

Osoby, które nie przestrzegają reguł i wartości reprezentowanych przez wspólnotę, a chcą być nadal jej uczestnikami, obejmuje się szczególną troską, polegającą między innymi na uświadomieniu konieczności przestrzegania przyjętych wcześniej reguł, dla dobra całej wspólnoty. W tym oddziaływaniu niebagatelne znaczenie ma stwierdzenie, czy takie zachowanie uczestników wynika $\mathrm{z}$ nieakceptowania podstawowych treści, jakie niesie ze sobą ta wspólnota, czy też wynika to z braku dostatecznej informacji na dany temat. W pierwszym przypadku zazwyczaj dochodzi do usunięcia osoby ze wspólnoty, dla dobra ogółu. W drugim przypadku, po przyswojeniu odpowiedniej dla potrzeb ilości informacji, zazwyczaj po krótszym lub dłuższym okresie dochodzi do ich internalizacji.

W jakim momencie należy wykluczyć ze wspólnoty osobę, która zdaje się żyć całkiem odrębnym życiem, pozostając jednak we wspólnocie, która sieje niezgodę i usiłuje podporządkować sobie najsłabszych, aby ich potem zniszczyć, wykorzystując do własnych celów ? Jedynie osoby odpowiedzialne i animatorzy mogą podjąć decyzję o wykluczeniu kogoś ze wspólnoty. Jeżeli już to robią muszą przy okazji uznać także swoją winę. Jeżeli czyjaś obecność staje się zgorszeniem dla najmłodszych we wspólnocie, trzeba zrezygnować z jego obecności. W trudnej dziedzinie rozłamów i podziałów nie sposób ustalić jakiejkolwiek reguły, poza zasadą cierpliwości, czujności oraz zdecydowania, poszanowania struktur, a także odwoływania się do dialogu. Każdy z członków wspólnoty musi bardzo uważać, by nie stać się przyczyną niezgody. Wszyscy uczestnicy wspólnoty winni być narzędziem jedności. Nikt z osób tworzących wspólnotę nie uchroni się od tej domieszki pychy zrodzonej z przewrażliwienia, dumy, która jeśli będziemy ją lekceważyć, ogarnie całą naszą istotę (25).

Analiza Skali Spójności Wspólnoty pozwala na stwierdzenie, że podstawą budowania struktur wspólnoty jest jasno określona hierarchia wartości i celów, jakie chce ona realizować. Takie jasne określenie (zdeklarowanie się) po stronie tych, czy innych wartości, pozwala na uniknięcie potencjalnych nieporozumień i dokonanie się wstępnej selekcji nowych członków wspólnoty, jeszcze przed formalnym przystąpieniem do niej. Na pewno pozytywnie wpływać to będzie na jakość i szybkość jej duchowego wzrostu. W świetle powyższego materiału hipotezę jedenastą uznano za zweryfikowaną.

Hipoteza dwunasta: Elementy wspólne dla wspólnot religijnych i społecznych, to struktury, sposoby (metody) działania, badania, pozyskiwania nowych członków. Do elementów rozłącznych dla obu kategorii wspólnot należy punkt odniesienia (system wartości) elementy łączące poszczególnych członków wspólnoty (tzw. spoiwo wspólnoty).

Wspólnota tym różni się od pozostałych grup społecznych, że jej członkowie sami określają warunki przynależności i łączącą ich więź, charakteryzują swe cele, a także 
jednoczącego ducha. Wspólnie uznają, że są za siebie odpowiedzialni. Grupa przyjaciół może przekształcić we wspólnotę, jeżeli będzie w niej wzrastało poczucie przynależności, jeżeli otworzy się na innych. Wspólnotę, której członkowie żyją w prawdziwym poczuciu przynależności do niej, cechuje otwartość, umiejętność przyjmowania oraz słuchania innych osób i grup ludzi. Żyć we wspólnocie, to znaczy burzyć bariery z myślą o tym - by przyjąć odmienność drugiego człowieka.

Zaangażowanie we wspólnotę nie dokonuje się na płaszczyźnie działania (jak w partiach politycznych). Należeć do wspólnoty, to przede wszystkim być. Jeśli człowiek ma zamiar zapuścić korzenie we wspólnotę, musi poczuć się w niej “jak u siebie”, musi uznać, że stanowi jej integralną część. We wspólnocie wszystko zaczyna się od wzajemnej komunii, zostaliśmy stworzeni do tego aby tworzyć jedno, aby być razem. Jeżeli kilka osób zgromadzi się w tym celu, aby wspólnie przeżywać codzienność, darzyć się wzajemnie miłością, dzieje się tak dlatego, że wszystkie te osoby poczuły, iż jako grupa mają misję do spełnienia, że mają innym przekazać prawdę o miłości (26).

Religijność jako zjawisko społeczne objawia się w relacjach interpersonalnych typu wspólnotowego, we wzajemnych interakcjach jednostek i grup społecznych, okazujących sobie szacunek lub jego brak. Człowiek jest zawsze podmiotem społecznych działań, jest miarą społeczeństwa i wszystkich jego instytucji (także wspólnot).

Fakt, że religijność rozwija się w społeczeństwie ludzkim, że kształtuje się w wyniku ludzkiego współżycia, że wpływa na zachowanie społeczne ludzi i reguluje stosunki interpersonalne, nie oznacza, że jest ona zjawiskiem wyłącznie społecznym, produktem czynników społeczno - kulturowych. Człowiek jest nie tylko istotą społeczną, ale i istotą indywidualną (osobą) posiadającą własne możliwości tworzenia i przekształcania świata przedmiotowego (27).

Do istnienia każdej wspólnoty, niezależnie od jej rodzaju, czy celów, potrzebne jest wyłonienie gremium kierującego, które będzie bardziej świadome zadań i posiadać będzie zdolności organizacyjne. Ważnym elementem w procesie formowania wspólnoty jest także umiejętność właściwego przekładania zadań ogólnych na zadania szczegółowe, dla konkretnych osób. Stają się one odpowiedzialne przed całością wspólnoty za ich realizację.

W zasadzie każda znana respondentom wspólnota, w swojej działalności opiera się na wzajemnej służbie uczestników o zasięgu wewnętrznym i zewnętrznym. Wszystkie znane wspólnoty starają się, aby ich członkowie wzrastali w świadomości całościowej wizji celów, dla jakich zostały one powołane.

Po przekroczeniu pewnego progu świadomości, we wspólnocie następuje przeobrażenie polegające na tym, iż osoby, które przekroczyły wspomniany próg świadomości, starają się "zarażać” tą wizją osoby spoza wspólnoty. Do większości wspólnot można włączyć się poprzez osobistą deklarację uczestnictwa i przestrzegania wartości, którymi dana wspólnota żyje. Z czasem następuje zaangażowanie w mniejszej lub większej grupie, przy realizacji celów szczegółowych, będących wyrazem i elementem realizacji celów ogólnych, do których stworzono wspólnotę.

Więź społeczna jaka łączy uczestników badanej wspólnoty najczęściej porównywano do miłości w znaczeniu agape - bezinteresownej przyjaźni, zaufania, solidarności.

Osoby spoza wspólnoty są traktowane jako pole do działania dla członków Ruchu. Są one obiektem oddziaływań przede wszystkim natury ewangelizatorskiej (we wspólnotach religijnych) i światopoglądowej (w innych wspólnotach). Warto zauważyć, że osoby spoza wspólnoty nie są traktowane jako "persona non grata", lecz jako potencjalni sojusznicy w realizowaniu wizji tej, czy innej grupy. 
Badania socjologiczne dowodzą, że najbardziej konformistycznie nastawione wobec wspólnoty są dwie kategorie społeczne a mianowicie sympatycy i kandydaci do danej wspólnoty. Sympatycy nie należą do danej wspólnoty, lecz akceptują wartości, wzory zachowań i normy danej grupy, to jednak w rzeczywistości intencjonalnie w niej uczestniczą. Wspólnota, z którą sympatyzują staje się dla nich punktem odniesienia normatywnego. R. Merton nazwał to zjawisko antycypacyjną socjalizacją jednostki.

Kandydaci do danej grupy różnią się od sympatyków tym tylko, że są oni już wstępnie przyjęci do danej wspólnoty. Stała się już inną dla nich grupą odniesienia normatywnego, jednakże ich uczestnictwo jest kontrolowane pod względem zgodności ich zachowań z wzorami i normami przyjętymi we wspólnocie (28).

Przyjmowanie do wspólnoty, a wcześniej "zdobywanie" nowych członków przebiega podobnie we wszystkich wspólnotach niezależnie od tego, czy są one typu religijnego, czy świeckiego. Odbywa się to poprzez osobiste, lub grupowe świadczenie o przeżyciach związanych z pobytem we wspólnocie, zafascynowanie jej celami i sposobem ich realizacji oraz ludźmi jacy ją tworzą.

W badanej wspólnocie takie działania nazywane są ewangelizacją indywidualną lub zbiorową (grupową). Swoistym magnesem przyciągającym nowych uczestników do wspólnoty Ruchu jest możliwość wzięcia udziału w rekolekcjach letnich, czy zimowych, w atrakcyjnych turystycznie miejscowościach górskich.

Sporadycznie zdarzają się takie przypadki zgłaszania się nowych uczestników do wspólnoty po ogłoszeniach w trakcie Mszy św.

Wypowiedzi uczestników na temat tego, co ich najbardziej pociąga we wspólnocie, podczas uczestnictwa w niej, oscylowały zazwyczaj wokół atrakcyjności proponowanej formacji deuterokatechumenalnej (jednak dopiero wtedy, gdy jest ona prawidłowo i integralnie prowadzona). Do czynników zniechęcających uczestników zaliczyć można brak integralnego programu formacji w wielu diakoniach, po ukończeniu formacji podstawowej, jak również stosunkowo mały stopień zaangażowania uczestników w życie kościoła parafialnego, poza strukturami wspólnoty. Większość respondentów zgadza się z decyzjami podejmowanymi przez animatora odpowiedzialnego za tą wspólnotę. Nawet w przypadku występowania niezgodności, wątpliwości, po ich wyjaśnieniu wszyscy starają się solidarnie realizować zaproponowany program działania.

Do wartości nadrzędnych, jakim służy każda wspólnota Ruchu, należy bardziej świadome (dojrzałe) i aktywne przeżywanie własnej wiary. We wspólnotach świeckich takimi wartościami nadrzędnymi jest poświęcenie się w realizacji takiej, czy innej wartości, uznawanej w kategoriach moralnych za dobro dla szerszego grona ludzi.

Spotkania takie odbywają się we wspólnotach, są jedną z podstaw ich działalności. Ich zadaniem jest właśnie jednoczenie i aktywizowanie uczestników do realizacji konkretnych działań. Są przy tym okazją do wzrostu świadomości celów, jakie dana wspólnota chce osiągać.

Większość respondentów uważa, że spotkania we wspólnocie wpływają pośrednio lub bezpośrednio na zmianę ich postępowania $w$ życiu codziennym. Zasadą spotkań formacyjnych w badanej wspólnocie jest możliwość ich kontynuacji i wzięcia udziału w rekolekcjach letnich, czy zimowych, w atrakcyjnych turystycznie miejscowościach górskich.

Sporadycznie zdarzają się takie przypadki zgłaszania się nowych uczestników do wspólnoty po ogłoszeniach w trakcie Mszy św.

Wypowiedzi uczestników na temat tego, co ich najbardziej pociąga we wspólnocie, podczas uczestnictwa w niej, oscylowały zazwyczaj wokół atrakcyjności proponowanej formacji deuterokatechumenalnej (jednak dopiero wtedy, gdy jest ona prawidłowo i 
integralnie prowadzona). Do czynników zniechęcających uczestników zaliczyć można brak integralnego programu formacji w wielu diakoniach, po ukończeniu formacji podstawowej, jak również stosunkowo mały stopień zaangażowania uczestników w życie kościoła parafialnego, poza strukturami wspólnoty. Większość respondentów zgadza się z decyzjami podejmowanymi przez animatora odpowiedzialnego za tą wspólnotę. Nawet w przypadku występowania niezgodności, wątpliwości, po ich wyjaśnieniu wszyscy starają się solidarnie realizować zaproponowany program działania.

Do wartości nadrzędnych, jakim służy każda wspólnota Ruchu, należy bardziej świadome (dojrzałe) i aktywne przeżywanie własnej wiary. We wspólnotach świeckich takimi wartościami nadrzędnymi jest poświęcenie się w realizacji takiej, czy innej wartości, uznawanej w kategoriach moralnych za dobro dla szerszego grona ludzi.

Spotkania takie odbywają się we wspólnotach, są jedną z podstaw ich działalności. Ich zadaniem jest właśnie jednoczenie i aktywizowanie uczestników do realizacji konkretnych działań. Są przy tym okazją do wzrostu świadomości celów, jakie dana wspólnota chce osiągać.

Większość respondentów uważa, że spotkania we wspólnocie wpływają pośrednio lub bezpośrednio na zmianę ich postępowania w życiu codziennym. Zasadą spotkań formacyjnych w badanej wspólnocie jest rozliczenie, na wstępie, uczestników poprzez ich własne wypowiedzi odnośnie realizacji w życiu treści przekazanych na spotkaniu poprzednim. Obliguje to $\mathrm{w}$ pewnym stopniu do zastanawiania się i podejmowania konkretnych zadań będących wypełnieniem tych treści, w tygodniu między spotkaniami. W ciągu tygodnia, w badanej wspólnocie odbywa się zazwyczaj jedno spotkanie formacyjne w poszczególnych małych grupach oraz jedno spotkanie ogólne dla całości wspólnoty. Spotkania ogólne mają charakter informacyjny, modlitewny, są poświęcone nauce nowych piosenek i szkoleniu liturgicznemu. Sporadycznie odbywają się Nabożeństwa Krucjaty Wyzwolenia Człowieka. Większość uczestników twierdzi, że nie uczestniczyło wcześniej w żadnej wspólnocie świeckiej. Ten ideał wspólnoty, jaki posiadają dzięki uczestnictwu w Ruchu Oazowym, pozostanie dla nich pierwowzorem w przypadku afiliacji do innych wspólnot (także świeckich).

Według uczestników, wspólnota religijna różni się od świeckiej przede wszystkim systemem uznawanych wartości, którym służy (zwłaszcza tym nadprzyrodzonym, mającym swe źródło w Bogu). Większy jest też zakres działania wspólnot religijnych, od wspólnot świeckich. Zbawienie duszy jest np. wartością bardziej cenioną przez respondentów, niż pokój w świecie (co nie oznacza, że jest on niepotrzebny).

Sporo trudności spowodowała odpowiedź na pytanie: dlaczego pojęcie wspólnoty tak rzadko kojarzy się w Polsce z Kościołem?

W niniejszej pracy oparłem się $\mathrm{w}$ zasadzie na odpowiedziach, jakie na to pytanie udzielili animatorzy badanej wspólnoty. Podsumować je można następująco. Ostatnie pięćdziesiąt lat eksponowano rolę hierarchii w walce $\mathrm{z}$ obowiązującym systemem wartości $\mathrm{w}$ państwie, wizję Kościoła jako wspólnoty zaczęto wprowadzać w życie tak naprawdę dopiero w początkach lat osiemdziesiątych, gdy nastąpił ogromny przyrost ilości wspólnot ruchów odnowy kościoła i ich uczestników.

W latach dziewięćdziesiątych ten proces uległ stopniowemu wyhamowaniu z uwagi na przemiany systemowe, jednak ruchy odnowy starają się dostosować do nowej sytuacji i kontynuować swoją misję realizowania Kościoła jako wspólnoty wspólnot. Temu służyć ma podejmowana również przez Ruch Oazowy akcja "Ewangelizacja 2000” i współpraca w ramach Rady Ruchów Katolickich z innymi wspólnotami odnowy Kościoła w Polsce. 
Odpowiedzialność za drugiego człowieka jest zadaniem każdego z ludzi, niezależnie do jakiego typu wspólnoty on należy.

W zasadzie każdy człowiek odczuwa potrzebę przebywania we wspólnocie (religijnej lub świeckiej), czyli w gronie osób, którym mógłby zaufać, które by zrozumiał i był przez nie rozumiany, gdzie mógłby się realizować.

Podstawą funkcjonowania każdej wspólnoty jest bezinteresowna miłość jej członków. Pozwala ona przeżywać wspólnotę zarówno w wymiarze wewnętrznym jak i zewnętrznym (jako swoistą więź między uczestnikami i jako określone struktury oraz metody działania).

We wspólnocie miłość nie wypływa z praktyki innych cech ją tworzących, lecz wszystkie cechy wspólnoty jako takiej wypływają z miłości. Z takim stwierdzeniem zgodzili się uczestnicy badanej wspólnoty. Większość uczestników, w tym animatorzy, są przekonani, że więź społeczna jaka łączy we wspólnocie jest skonstruowana bardziej na zasadzie sieci niż łańcucha. Analiza Skali Spójności Wspólnoty powyższe stwierdzenia weryfikuje. To pozwala także na zweryfikowanie hipotezy dwunastej.

Hipoteza trzynasta: Do pozareligijnych wspólnot interpersonalnych zaliczyć można, w ramach mezostruktur ruchy abstynenckie, Monar, ruchy alternatywne i oparte na subkulturach muzyki rockowej. Do wspólnot świeckich o zasięgu mikrostrukturalnym zaliczyć można grupy terapeutyczne, sąsiedzkie, rodzinne, jak również te oparte na wspólnocie śmiechu.

Do pozareligijnych wspólnot uczestnicy badanej wspólnoty zaliczyli ruchy alternatywne, skauting, grupy terapeutyczne i prowadzące działalność odwykową w trybie stacjonarnym. Większość uczestników zalicza do takich wspólnot także grupy rówieśnicze, sąsiedzkie, wywodzące się z subkultur poszczególnych gatunków muzyki rockowej oraz oparte na tzw. wspólnocie śmiechu.

Niepodważalną rolę ma wśród wyżej wymienionych oczywiście rodzina, którą wszyscy uczestnicy wymieniali na pierwszym miejscu. Pewne wątpliwości może budzić zaliczenie grup typu terapeutycznego lub wywodzących się z subkultury muzycznej, do wspólnot (grup pierwotnych). Takiej klasyfikacji dokonałem kierując się definicją grupy pierwotnej J. Turowskiego (29).

Według tego autora grupa pierwotna to taka, która obejmuje i kształtuje całość osobowości swoich członków.

A. Kłoskowska szeroko komentuje rolę, jaką przypisał amerykański socjolog C. Cooley działaniu grup pierwotnych (wspólnot).

"Są one źródłem elementarnych związków społecznych i ideałów moralnych, źródłem wszystkich decydujących o społecznym współżyciu pozytywnych uczuć, które zgodnie z optymistycznym poglądem Cooleya górują nad negatywnymi. Uniwersalność grup pierwotnych tego typu co rodzina i sąsiedztwo jest według Cooleya założeniem oczywistym, nie wymagającym dowodu. Powszechność występowania grup rówieśniczych, koleżeńskich młodzieży w różnych społeczeństwach i kulturach potwierdzają między innymi obserwacje dzieci imigrantów o różnym pochodzeniu etnicznym. Wreszcie bliskość i zrozumienie wielkiej literatury różnych epok i kultur dla ludzi naszej epoki dostarcza potwierdzenia uniwersalizmu uczuć i postaw moralnych, będącego wynikiem zasadniczego podobieństwa charakteru wszystkich grup pierwotnych (wspólnot), we wszystkich społeczeństwach (30).

Użycie nazwy "wspólnota" dla określenia grupy państw socjalistycznych, jest zdaniem respondentów, wypaczeniem całej idei wspólnoty. Praktyczna realizacja wzajemnych kontaktów, na przestrzeni do roku 1989 dowodzi, że można zakwalifikować te państwa raczej jako instytucje totalne o zasięgu makrostrukturalnym niż jako wspólnoty. Nazwa 
"wspólnota" państw socjalistycznych nie miała żadnego odzwierciedlenia w rzeczywistości społecznej.

Wspólnoty młodzieżowe oparte na muzyce młodzieżowej bywają nietrwałe, jak nietrwała jest moda na poszczególnych wykonawców, czy gatunki muzyki współczesnej. Należy przy tym dodać, że jednym z elementów przyciągających nowych członków do wspólnot Ruchu Oazowego, zwłaszcza w latach siedemdziesiątych i osiemdziesiątych, była chęć włączenia się w nurt odnowy muzyki sakralnej.

Spośród wielu wspólnot młodzieżowych, najbardziej przystają do definicji wspólnoty "komuny hipisowskie" z przełomu lat sześćdziesiątych i siedemdziesiątych obecnego stulecia.

Powstały one w większości w 1967 r. jednak już dzień 14.01.1967 r. jest uznawany za formalną datę proklamacji ruchu hipisowskiego. W czasie tego wydarzenia, które odbyło się w San Francisco uwidocznione zostały wszystkie hasła i symbole ruchu hipisów, znane do dziś: miłość, LSD (narkotyki), czyń miłość nie wojnę, wszyscy ludzie stanowią jedność, nie bądź nienawistny.

Dużą popularnością wśród hipisów cieszyła się religijność buddyjska w wersji “zen”. Początkowo uważano ruch hipisów za ruch śmieszny, barwny i niegroźny dla społeczeństwa. W drugiej połowie1967 r. prasa amerykańska zaczęła publikować informacje o faktach z życia tego ruchu, mających istotne znaczenie $\mathrm{w}$ naruszaniu porządku prawnego $\mathrm{w}$ wielu krajach zachodnich.

Nastąpił pięćdziesięcioprocentowy wzrost ucieczek $\mathrm{z}$ domu osób nieletnich, sześciokrotny wzrost zachorowań na choroby weneryczne wśród młodzieży, używanie narkotyków doprowadzało do krańcowego wyczerpania i otępienia umysłowego oraz nasilenie się tendencji samobójczych wśród młodzieży (31).

Do najbardziej znanych zespołów generujących rozwój subkultury hipisowskiej należały między innymi "Jefferson Airplane", które członkowie przez 8 lat tworzyli zwartą komunę hipisowską w San Francisco. Innym zespołem był "Grateful Dead”, przedstawiciel tzw. rocka psychodelicznego, komponowanego i aranżowanego pod wpływem narkotyków.

Wielu wykonawców epoki hipisów zakończyło swoje życie wskutek przedawkowania narkotyków. Przykładem tego może być chociażby Janis Joplin, Jim Morrison, Jimmi Hendrix.

W okresie powstawania i rozkwitu ruchu hipisowskiego miały miejsce dwa słynne koncerty, które przez niektórych członków badanej wspólnoty Ruchu Oazowego są postrzegane jako wyraz budowania wspólnoty w skali makro. Przytaczane są tu przykłady koncertu w Monterey w 1967 r. oraz Woodstock w 1969 r. Atmosfera jaka towarzyszyła tym koncertom miała w sobie wiele cech wspólnoty, jednak zakończyła się z chwilą zakończenia występów poszczególnych zespołów.

W Polsce próbuje się wprowadzić wzory z państw zachodnich w różnych dziedzinach życia. Przykładem jest działalność Monaru, opartego na wypracowanych wcześniej w Stanach Zjednoczonych wzorcach kuracji antynarkotycznej, przez jedną $\mathrm{z}$ grup terapeutycznych.

Działając od kilkunastu lat Monar zdążył już stworzyć podstawy do zaistnienia wielu wspólnot terapeutycznych, zwłaszcza w mniejszych miejscowościach. Jego działalność jednak nie zawsze spotyka się ze zrozumieniem, czego przykładem może być zachowanie ludności podwarszawskich Lasek. Aktualnie stosunkowo duży odsetek osób, którymi opiekuje się Monar jest zarażona wirusem HIV i akcent w działalności tego ruchu przesuwa się na zapobieganie temu zagrożeniu. W okolicach badanej parafii ma niedługo powstać ośrodek terapeutyczny Monaru w jednej z wiosek. Przed poparciem tej inicjatywy władze 
samorządowe musiały zasięgnąć opinii mieszkańców osady. Decydującym argumentem, jaki przeważył w dyskusji była obietnica zatrudnienia kilkunastu osób bezrobotnych, w ramach technicznej obsługi ośrodka. W gminie, gdzie bezrobocie sięga $40 \%$ jest to sprawa niebagatelna.

Ruch Anonimowych Alkoholików, wspólnoty Al - Anoon i Al - Ateen są postrzegane przez oazowiczów podobnie jak Monar. Pierwszy ruch zrzesza samych alkoholików i prowadzi poprzez terapię grupową we wspólnocie, kurację odwykową, dwa pozostałe ruchy mają za zadanie odpowiednio przygotować osoby dorosłe i dzieci żyjące $\mathrm{w}$ rodzinie $\mathrm{z}$ osobami uzależnionymi od alkoholu.

Wspomagające działania tych trzech ruchów mają na celu przedłużenie okresu terapii na czas przebywania $\mathrm{w}$ gronie rodzinnym. Cele, jakie przyświecają tym ruchom, są przez członków badanej wspólnoty Ruchu całkowicie akceptowane.

Na terenie Polski w wielu miejscach, gdzie istnieją sformalizowane wspólnoty tych ruchów dochodzi do współpracy na płaszczyźnie działania diakoni wyzwolenia. W badanej miejscowości ruch Anonimowych Alkoholików w zasadzie nie istnieje. Podejmowane kilkakrotnie próby powołania takich struktur nie przyniosły oczekiwanych efektów. Należy zauważyć, że spożycie alkoholu na jednego mieszkańca w badanej miejscowości jest jednym z najwyższych w województwie.

Na pytanie - jaki błąd popełnili realizatorzy wizji komunizmu, jako społeczeństwa wspólnoty, respondenci zauważyli, że podstawą całego programu, powstałego w XIX w. była praca, dyktatura klasy robotniczej. Zabrakło przy tym dążenia do wzajemnego zrozumienia i zaufania, ducha tolerancji i przebaczenia. Twórcy wspomnianej idei założyli też, że istnieje jeden model życia wspólnotowego - komuna, do której za wszelką cenę należy dążyć. Wszelkie odstępstwa bezwzględnie zostały niszczone po uprzednim opatrzeniu ich etykietką rewizjonizmu itp.

W związku z tym, że badania przeprowadzono w małym mieście, dużą rolę odgrywa $\mathrm{w}$ nim tzw. wspólnota sąsiedzka. Polega ona przede wszystkim na pogłębianiu wzajemnego zaufania, pomocy $\mathrm{w}$ chwilach trudnych, na głębokiej przyjaźni, zrozumieniu problemów drugiej rodziny.

Podobnie rzecz przedstawia się w przypadku analizowania wizji wspólnoty rodzinnej, w oparciu o wypowiedzi uczestników Ruchu. Tworzy ją solidarność, oparta na miłości i bezinteresowna pomoc w każdym problemie, utrzymywanie kontaktów z rodziną i domem rodzinnym nawet po jego opuszczeniu w wyniku założenia nowej rodziny.

Na pytanie dotyczące tzw. wspólnoty śmiechu, większość uczestników wspólnoty nie odpowiedziała, traktując je jako dowcip. Osoby, które udzieliły odpowiedzi, stwierdziły, że nawet jeśli takowa wspólnota istnieje, jest bardzo krótkotrwała, nie posiada żadnych stałych struktur, swoim zasięgiem jednak poprzez środki społecznego komunikowania (radio, telewizja, video) może jednoczyć wiele ludzi.

Wszyscy uważają wspólnotę zarówno religijną, jak i świecką za coś naturalnego, a nie sztuczny twór. Uważają też, że grupa stworzona sztucznie, nigdy nie będzie wspólnotą, nigdy nawet nie będzie dążyć do tego, by być wspólnotą.

Stworzenie wspólnoty pozareligijnej na szczeblu wyższym niż wspólnota podstawowa, jest zadaniem bardzo trudnym, jeśli nie niemożliwym do realizacji.

Wszyscy uczestnicy badań twierdzą, że wspólnota religijna jest bardziej trwałą strukturą, ponieważ dodatkowo opiera się na wartościach nadprzyrodzonych.

Funkcjonowanie każdej wspólnoty nie pozwala jej członkom na przeżywanie jakiejkolwiek formy osamotnienia. Jest ona okazją do znoszenia ciężarów życia z drugim 
człowiekiem. Życie we wspólnocie opiera się także na tolerancji, przebaczeniu, oraz akceptacji drugiego człowieka takim, jakim jest.

Powyższe stwierdzenia pozwalają na zweryfikowanie hipotezy trzynastej.

Hipoteza czternasta: Wspólnota jest tworem emergentnym, ponieważ nie powstaje jako suma wartości osób i zachowań poszczególnych jej uczestników, lecz jednocząc wszystkich w sobie, tworzy nową jakość społeczną (religijną) odmienną od pojedynczych elementów składowych.

W wyniku przemian, w ostatnich latach Kościół nie zawsze udziela ludziom współczesnym dostatecznych odpowiedzi na pytania i problemy, jakie stawia przed nimi codzienne życie. Wartości chrześcijańskie straciły na ważności w społeczeństwie, a rzeczywisty system wartości reprezentowany przez ludzi współczesnych ma wiele znamion pluralizmu o zabarwieniu synkretycznym. Zaznaczająca się w rzeczywistości społecznej religijność ma przede wszystkim charakter selektywny i charakteryzuje się częściową identyfikacją z wiarą i moralnością chrześcijańską. Ma ona profil częściowo kościelny, częściowo zdystansowany wobec Kościoła. Częściowo odpowiada oczekiwaniom Kościoła, częściowo wykazuje relatywną niezależność, odbiegającą od oficjalnych wzorców religijnych. Katolicy o postawach selektywnych, reprezentują w sposób nierównomierny poszczególne elementy religijności kościelnej, wybierane na drodze w pełni świadomej lub nie w pełni świadomej selekcji z wartości przekazywanych przez Kościół (32).

Istnienie emergencji w świecie społecznym, akceptacja tezy o jakościowym zróżnicowaniu rzeczywistości społecznej nakazuje rozważanie także problemu struktury emergencyjnej rzeczywistości wspólnoty. Strukturę jakościową (emergencyjną) możemy ustalić jedynie dla rzeczywistości wspólnoty en bloc (jako mezostruktury w ramach parafii). Zróżnicowanie jakościowe ujawnia się bowiem dopiero wówczas, gdy zastosuje się odpowiednio szeroką perspektywę spojrzenia. Dążenia do ustalenia struktury jakościowej rzeczywistości wspólnoty będą (choć nie zawsze) dążeniami zmierzającymi do przypisania tej rzeczywistości jakiejś jednej z jej struktur jakościowych. Jeśli tak, to w granicach dociekań filozoficznych, leży nie tylko teza, że rzeczywistość wspólnoty jest jakościowo zróżnicowana oraz, że można jej przypisać jakąś strukturę jakościową, lecz także określone rozstrzygnięcie w tej materii. Nie można zatem poprzestać na tezie o istnieniu zróżnicowania jakościowego rzeczywistości wspólnoty, ale wymaga się aby wysunąć jakiś określony model struktury wspólnotowej (33).

Już w najmniejszych i najprostszych typach struktur społecznych ujawniają się takie ich właściwości, które wymagają całkowicie odrębnych środków analizy i odrębnej aparatury pojęciowej do ich wyjaśniania. Już te najprostsze rodzaje ponadindywidualnych struktur okazują się być emergentne, jakościowo odmienne od zachowań jednostek i ich indywidualnych działań (34).

Poprzez uczestnictwo we wspólnocie oazowej zachodzi proces konwersji i internalizacji ze wzorcami proponowanymi przez nią. Uczestnicy mają tego świadomość i zgodnie stwierdzają, że uczestnictwo w tej konkretnej wspólnocie miało wpływ na zmianę ich patrzenia na Kościół i otaczający świat.

Wszystkie znane wspólnoty starają się wpływać na zaangażowanie się swoich uczestników, kształtują postawy odpowiedzialności za własne słowa i czyny, uczą akceptacji inności drugiego człowieka. Ważną rolę odgrywają także przy odkrywaniu i realizowaniu swojego życiowego powołania poprzez poszczególnych uczestników.

Jako wyraz emergentności wspólnoty może posłużyć zdanie, z którym utożsamiają się zwłaszcza animatorzy badanej wspólnoty: "przyjmujemy człowieka zawsze takim jakim jest, ale nie pozwalamy mu na zawsze takim pozostać”. Animatorzy stwierdzili także, iż 
wspólnota jako całość nie może być postrzegana jako suma wartości osób, które ją tworzą. Wspólnota tworzy zawsze nową jakość, odmienną od sumy wartości jej elementów składowych. Niebagatelną rolę w procesie tej przemiany ma konwersja. W oczach innych ludzi wspólnota jest i powinna być postrzegana zawsze jako całość, a nie jako suma jednostek. Tylko przy takiej optyce patrzenia na wspólnotę można odkryć jej piękno, siłę oddziaływania i atrakcyjność.

W związku z tym, że badania przeprowadzono w małym mieście, dużą rolę odgrywała w nim tzw. wspólnota sąsiedzka. Sama wspólnota jest czymś więcej niż tylko grupą społeczną, dlatego nie powinna być z nią utożsamiana. Jako twór naturalny, przy tym jest częścią świata społecznego i żaden aspekt patrzenia na ten świat nie powinien jej $\mathrm{z}$ całościowej wizji wyłączać.

We wspólnocie, według respondentów, największy wpływ na ich przemianę ma specyficzna więź łącząca poszczególnych uczestników, poziom porozumienia między nimi i wzajemna akceptacja oraz zaangażowanie przy wspólnych działaniach.

Po wyjaśnieniu terminu emergencja, większość badanej wspólnoty zauważyła, że podstawową wspólnotą emergentną jest rodzina, która przez działalność prokreacyjną tworzy nową jakość społeczną. Oczywiście nie należy zamykać procesu przekształceń w rozumieniu świata, u małżonków tylko przez pryzmat prokreacji. Przez wspólnotę zamieszkania, wspólnych zadań na polu wychowania i zapewniania rodzinie środków do utrzymania, tworzy się w oczach małżonków zupełnie inny obraz, niż ten z jakim mieli do czynienia przed zawarciem związku. Każda wspólnota religijna, która zakłada konwersję swoich uczestników powinna być uznana za twór emergentny.

Herezja przy tym polega na zbytnim przeakcentowaniu jednej prawdy wiary kosztem innych. Ktoś przywiązując zbytnią wagę do jednego elementu deformuje całość. Schizma natomiast jest podziałem struktur kościelnych. Schizma w XVI w. to zupełnie coś innego aniżeli schizma XI w. Tam (schizma wschodnia) u podstaw były dążenia władcze monarchów, ich ambicje, tu mamy do czynienia $\mathrm{z}$ napięciami wynikłymi wskutek rozwiązania ruchu charyzmatycznego.

Protestantyzm w imię reformy kościoła zaproponował zupełnie inny sposób rozumienia chrześcijaństwa. Tak inny, że właściwie zakwestionował sensowność istnienia Kościoła (35).

Według członków badanej wspólnoty herezje i schizmy powstają, gdy wierni odczuwają kościół bardziej jako instytucję i organizację niż wspólnotę.

Nie oznacza to, że należy w imię unikania herezji i schizm pozbawić Kościół struktur organizacyjnych.

Problem polega na właściwym rozłożeniu akcentów. Aby odczuwać małą grupę jako wspólnotę, uczestnicy i animatorzy zgodnie stwierdzili, iż optymalnym rozwiązaniem jest ustalenie dopuszczalnej wielkości grupy na 3 - 8 osób, zaś maksymalną liczbą uczestników grupy jest 15 osób. Wobec powyższych ustaleń hipotezę czternastą uznano za zweryfikowaną.

Hipoteza pietnasta: Wspólnoty, zarówno w ujęciu społecznym, jak i religijnym, funkcjonują na zasadach określonych w pojęciu consensus, jednak we wspólnotach religijnych, odpowiedzialność za podejmowanie decyzji jest scedowane na jedną osobę.

$\mathrm{Z}$ zaleceniami dotyczącymi podziału kompetencji, wiąże się metoda obejmująca zalecenia $\mathrm{w}$ zakresie określania uprawnień do podejmowania decyzji. W każdym systemie społecznym i większości grup społecznych współistnieją elementy i składniki organizacji formalnej i nieformalnej. W związku z tym dochodzi często do rozdwojenia kompetencji i faktycznego rozdźwięku w podejmowaniu decyzji (36). 
Osoby podejmujące decyzje we wspólnocie winny mieć jasno określoną hierarchię ważności, jeżeli pogubią się w nawale drobiazgów szybko mogą zatracić wizję wspólnoty. Najlepszym odpowiedzialnym za wspólnotę jest ten, kto sam robi stosunkowo niewiele, lecz za to przypomina pozostałym o tym co wydaje się najważniejsze w ich życiu, zachęca ich do wywiązywania się z powierzonych zadań, wspiera ich, potwierdza słuszność poczynań i równocześnie kontroluje.

$\mathrm{Na}$ początku istnienia wspólnoty o wszystkim decyduje jej założyciel. Stopniowo przybywają jego współpracownicy, powstają więzi wspólnotowe. Wówczas odpowiedzialny pyta ich o zdanie, rodzi się wspólny duch podejmowania decyzji. Bardzo istotny jest moment, kiedy założyciel wspólnoty odkrywa, iż ona nie stanowi jego osobistego pomysłu, lecz jest częścią nadrzędnego planu, a jej przywódca jest tylko narzędziem. Wspólnoty powstają dla tworzących ją osób, nie dla założyciela. Odpowiedzialność jest krzyżem, który on musi nieść, ale którego ciężarem bardzo prędko powinien się podzielić, tak aby mogły się ujawnić dary każdego z członków wspólnoty (37).

Lider wspólnoty religijnej powinien pociągnąć ją do ideału, pomagać wzrastać w relacji do ideału, pomagać ludziom gromadzić się w celu tworzenia wspólnoty opartej na ideale. Przywódcą we wspólnocie jest ten, który skłania ludzi do przyjęcia pewnych wartości, postaw, który motywuje ich do utworzenia wspólnoty.

W pewnym sensie ten rodzaj jest przywództwem funkcjonalnym. Nadrzędnym kryterium efektywności nie jest tutaj zdolność do wykonywania określonej pracy, ale zdolność do zainspirowania ludzi do dobrowolnej pozytywnej odpowiedzi (38).

$\mathrm{Z}$ zaleceniami dotyczącymi podziału kompetencji wiąże się metoda obejmująca zalecenia podejmowania decyzji przez wspólnotę. Nierozłącznie kojarzy się ona z pojęciem consensus. Jest to określenie zasadniczo różne od metody demokratycznej(opartej na przewadze większości), nawiązujące do próby znalezienia elementów wspólnych w zdaniach poszczególnych członków gremium decydentów.

Szczegółowo problemy związane z właściwą interpretacją tego pojęcia przedstawiono w trzecim rozdziale niniejszej pracy. Pod pojęciem demokracja, większość uczestników rozumie nie encyklopedyczne rządy ludu, lecz możliwość podejmowania decyzji przez ogół wolą większości. Wielkość grupy - w której zachodzą procesy decyzyjne wpływa znacząco na ich podejmowanie. Im większa grupa, tym trudniej jest doprowadzić do consensusu $\mathrm{z}$ uwagi na większe zróżnicowanie uczestników. Wielkość grupy ma także swoje strony pozytywne. Pozwala bowiem na bardziej wszechstronne zanalizowanie problemu.

Większość członków badanej wspólnoty ruchu jest zdania, że decyzje w niej powinny być podejmowane metodą consensusu. $Z$ rolą animatora we wspólnocie wiąże się wypełnianie roli osoby aktywizującej duchowo uczestników, mobilizującej ich do konkretnych działań i ukazujących przez własny przykład, drogi realizacji celów i zadań, jakie postawiono przed tą wspólnotą. Do zadań animatora odpowiedzialnego za wspólnotę należy właściwe odczytanie "znaków czasu", czyli odczytanie zadań, jakie stoją przed wspólnotą w konkretnym miejscu i czasie oraz takie pokierowanie działalnością całej wspólnoty, aby swoje zadania mogła zrealizować. W czasie ostatnich kilku lat w badanej wspólnocie dostrzeżono spadające zainteresowanie jej problemami przez moderatora (lub duchownego - opiekuna). Na pewno wpływa na to duża rotacja na tym stanowisku. W ciągu sześciu lat zmieniło się 5 opiekunów wspólnoty. Scedowanie większej odpowiedzialności za losy wspólnoty w ręce osób świeckich jest zmianą w duchu przemian soborowych.

W przypadku jednak Ruchu Oazowego, który duży nacisk kładzie na formację liturgiczną, modlitewną (duchową), wskazane jest by w takich spotkaniach, przynajmniej od czasu do czasu brali udział duchowni. Nie istnieją jakiekolwiek ograniczenia ze strony 
formalnej, by opiekun wspólnoty uczestniczył w spotkaniach formacyjnych poszczególnych grup. Jest to tym bardziej pożądane, że niemal wszystkie grupy opierają się w swoich rozważaniach na interpretowaniu cytatów z Pisma św.

W przypadkach braku możliwości podjęcia decyzji we wspólnocie drogą consensusu, czy demokratyczną, animatorzy wyrazili swoją opinię, że należałoby scedować podjęcie decyzji na osobę uznaną za najbardziej świadomą celów wspólnoty, a przy tym odpowiedzialną. Chodzi tu oczywiście o osobę świeckiego odpowiedzialnego. Podzielone były zdania na temat tego, czy decyzje podejmowana drogą consensusu są bardziej trafne, niż te podejmowane metodą większości (demokratyczną). Respondenci uważali, że każda z tych metod ma swoje dobre i złe strony, a trafność podejmowanych decyzji i tak zweryfikuje życie wspólnoty. We wspólnocie decyzje metodą consensusu powinni podejmować przede wszystkim animatorzy, prowadzący małe grupy formacyjne lub diakonijne. W przypadkach gdy problem nie da się wyjaśnić metodą consensusu, potrzebne jest zastosowanie innej skutecznej metody. Taką metodą może być również metoda większościowa. Na bazie powyższych stwierdzeń hipotezę piętnastą uznano za zweryfikowaną.

\section{Przypisy do rozdziału V.}

1. A. Sosnowski: Rozwój Ruchu Oazowego wśród młodzieży osiedlowej, Szczecin 1988 (maszynopis powielany), s. 21.

2. Ibidem: s. 22-29.

3. Ibidem: s. 29-30.

4. R. Woźniak: Problemy struktur społecznych, a badania socjologiczne, w: Roczniki Koszalińskie 1982, s. 21.

5. Ibidem: s. 19.

6. Ibidem: s. 17.

7. S. Clark: Budowanie wspólnot chrześcijańskich, Wrocław 1994, s. 59-61.

8. Ibidem: s. 88-94.

9. Ibidem: s. 175-176.

10. Ibidem: s. 134-137.

11. J. Vanier: Wspólnota miejscem radości i przebaczenia, Warszawa 1991, s. 190-212.

12. Ibidem: s. 347-348.

13. R. Dudek (red) - Być świeckim, Kraków 1993, s. 181-182.

14. E. Pleń: Animator Grupy Młodzieżowej, Warszawa 1994, s. 179-182.

15. D. Bromley, J. Richardson (red): The Brainwashing. Deprogramming Controversy, New York 1983, s. 296.

16. J. Downton: An Evolutionary Theory of Spiritual Conversion on Commitment, w: Journal for the Scientific Study of Religion 4 (1980) 381-396.

17. E. Goffman: Asylums, Chicago 1968, s. 6. 
18. J. Mariański: Religijność w procesie przemian. Warszawa 1991, s. 247-248.

19. R. Dudek: op. cit. s. 176.

20. E. Pleń: op. cit. s. 70-71.

21. F. Lenoir: Nowe wspólnoty, Warszawa 1993, s. 269.

22. J. Urtaga: Chrześcijanie do boju, Warszawa 1994, s. 213.

23. J. Turowski: Socjologia, Lublin 1993, s. 133.

24. Ibidem: s. 133-135.

25. J. Vanier: op. cit. s. 146-147.

26. Ibidem s. 25-99.

27. J. Mariański: op. cit. s. 30.

28. J. Turowski: op. cit. s. 125.

29. Ibidem: s. 110.

30. A. Kłoskowska: Małe grupy społeczne i społeczeństwo masowe,w: Kultura i społeczeństwo 3/1959, s. 75.

31. J. Wójcik: Od hipisów do szatanistów, Warszawa 1992, s. 54-57.

32. J. Mariański: op. cit. s. 127.

33. J. Szmatka: Elementy mikrosocjologii. cz. II Kraków 1992, s. 26.

34. Ibidem: s. 27.

35. E. Staniek: Bogactwo tajemnicy Kościoła, Kraków 1990, s. 34-46.

36. J. Turowski: op. cit. s. 147.

37. J. Vanier: op. cit. s. 132-133.

38. S. Clark: op. cit. s. 134-144. 


\section{PODSUMOWANIE WYNIKÓW BADAŃ. WNIOSKI}

Wspólnota jest grupą społeczną cechującą się pewną formą stabilizacji, powstaje, gdy ludzie związani ze sobą w sposób stały i regularny żyją, pracują lub wspólnie spędzają wolny czas, gdy z określonej przyczyny systematycznie przybywają razem. Wspólnoty mogą kształtować się na poziomie lokalnym, regionalnym ale $\mathrm{i}$ w ramach małych grup. Przyjmują one zawsze wspólne postawy i wartości. Nie każdy człowiek w danej wspólnocie musi przyjmować wszystkie postawy i wartości jakie ją charakteryzują, ale generalnie są one przyjmowane i stanowią o jej specyfice.

Wspólnoty wywierają wielki wpływ na swoich członków. Fakt pobytu w danej wspólnocie wywiera na każdej osobowości niezatarte piętno. Oczywiście nie jest prawdą, że człowiek jest całkowicie zdeterminowany przez swoją wspólnotę, ponieważ do pewnego stopnia ma możliwość wyboru pomiędzy różnymi środowiskami i wspólnotami. Rodzaj wspólnoty zależy od wzajemnych oddziaływań międzyludzkich.

Wierzenia, postawy, wartości i wzorce zachowania (zatem i postawy) danej osoby są w dużym stopniu kształtowane przez wspólnotę w jakiej przebywa. Człowiek potrzebuje wspólnoty, aby prowadzić swoje człowieczeństwo ku dojrzałości. W tym procesie społecznego dojrzewania bardziej podstawowe są czynniki środowiskowe niż instytucjonalne, dlatego pierwszoplanową troską powinno być raczej tworzenie wspólnot niż reformowanie instytucji. Skoro trudno się spodziewać, że społeczeństwo jako całość przyjmie model określonej wspólnoty, wobec twego konieczne jest tworzenie wewnątrz społeczeństwa takich wspólnot, które umożliwią prowadzenie życia zgodnego z wcześniej deklarowanymi wartościami (np. chrześcijańskimi).

Wspólnota jest rodzajem środowiska, jego silną i efektywną formą. Istotą wspólnoty jest grupa ludzi i ich wspólne spotkanie, nie zaś spełnianie wymogów formalnych. Żadne ze spotkań wspólnotowych nie angażuje wszystkich jej członków, wszystkie jednak z niej wyrastają i stanowią część jej życia. Gdy ktoś staje się członkiem wspólnoty, jest zapraszany do służby innym we wspólnocie. Organizacyjna strona każdej wspólnoty powstaje, aby wychodzić naprzeciw potrzebom odczuwalnym przez wspólnotę, a nie po to by organizować spotkania, czy posługi, których wspólnota powinna "chcieć".

Przywództwo we wspólnocie jest zazwyczaj typu naturalnego, wyłaniającego się w procesie organicznego wzrostu wspólnoty. Każdą wspólnotę cechuje duża żywotność, opiera się ona przede wszystkim na relacjach interpersonalnych, a nie na programach, czy działaniu (1).

Tworzenie wspólnoty (zwłaszcza wśród osób młodych) nie jest sprawą łatwą, mimo iż wiele osób tego pragnie. Ludzie falują między udręką samotności i obawą zależności. Ta pierwsza prowadzi ich do poszukiwania miejsca całkowitego połączenia z innymi osobami podobnie myślącymi. Druga prowadzi do doświadczenia cierpienia w byciu razem, w odczuwaniu siebie, jako niezdolnych do komunikacji, do nieznoszenia wzajemnego zaangażowania, ponieważ wydaje się to manipulacją ich wolności i autonomii. Wspólnota staje się tutaj miejscem, gdzie zostają wyładowane napięcia (stresy) przeciwko wszelkim formom ograniczenia i jakiejkolwiek strukturyzacji relacji z innymi. Taka sytuacja jest przeżywana dzisiaj w sposób bardzo dramatyczny, zwłaszcza przez młodzież pogrążoną w społeczeństwie i kulturze, które promują poszukiwanie osobistego sukcesu i indywidualizmu. To samo społeczeństwo popycha ku szybkiej ewolucji sposobów myślenia i działania. Sugeruje selektywność i elastyczność w przynależeniu $\mathrm{w}$ taki sposób, by nie wiązać się zbytnio, oraz by nie zamykać sobie możliwości dokonywania innych wyborów. Wszystko to 
popycha ludzi do odrzucenia tego, co prezentuje się jako najmniejsza choćby norma, prawo, jako instytucja, co wydaje się blokować proces rozwoju osoby. Każda przynależność jest przeżywana w sposób selektywny, aż do momentu, gdy nie przynależy się do jakiejkolwiek wspólnoty, chociaż uczęszcza na spotkania wielu grup.

Trudności w przeżywaniu wspólnoty powinny być także postrzegane także w świetle kryzysu procesów pierwszej socjalizacji w rodzinie i szkole. W takich kontekstach ludzie doświadczają często kryzysu związanego z opuszczeniem, samotnością, a nade wszystko nie otrzymują odpowiedniej formacji do interakcji osobistej i komunikacji grupowej. W konsekwencji są ubodzy, gdy chodzi o zdolność tworzenia relacji stabilnych i głębokich, a przede wszystkim zdolność poważnego włączenia się w tkankę relacji instytucjonalnych. Poszukiwanie wspólnoty jest przestrzenią przyjaźni, jest ucieczką od rzeczywistości społecznej, otwartej. Taki stan rzeczy powoduje, że młodzi ludzie doświadczają szczególnego skrępowania, gdy chodzi o wspólnoty bardziej zinstytucjonalizowane jak rodzina, grupa rówieśnicza klasy szkolnej, wspólnoty kościelne i inne grupy o programie działania określonym z góry. Przynależność do jakiejś z tych wspólnot jest tak selektywna w relacjach, że staje się niezdolna do stworzenia jednego podmiotu wychowawczego. Skrępowanie niektórych wobec wspólnot kościelnych objawia się jako nietolerancja dla ograniczeń, wydaje się, że wszystko jest narzucone, chociaż przy pomocy wyszukanych środków, i że brakuje miejsca na wolność, poszukiwanie, porównanie idei (2).

Ażeby pełniej sprecyzować ów wymiar wspólnoty, właściwy dla międzyosobowej relacji "ja-ty”, należy stwierdzić, że właśnie w tych relacjach dokonuje się wzajemne ujawnienie człowieka w jego osobowej podmiotowości, we wszystkim co tę podmiotowość stanowi. "Ty" staje się wobec "ja" jako prawdziwe i pełne "drugie ja", o którym stanowi nie tylko samoświadomość, ale nade wszystko samoposiadanie i samopanowanie. W tej podmiotowej strukturze "ty" jako "drugie ja" reprezentuje własną transcendencję, i własną dążność do samospełnienia. Cała ta struktura osobowej podmiotowości właściwa dla "ja” i "ty" jako drugiego "ja" poprzez wspólnotę właściwą dla "ja” i "ty" doznaje wzajemnego ujawnienia, gdyż dzięki wzajemnej relacji "ja” jestem równocześnie "ty”. W ten sposób na gruncie relacji "ja -ty" $\mathrm{z}$ samej natury wspólnoty interpersonalnej rośnie wzajemna odpowiedzialność osoby za osobę, a odpowiedzialność ta jest refleksem sumienia i transcendencji, która zarówno po stronie "ja" jak i "ty" staje na drodze do samospełnienia, warunkując właściwy (autentycznie osobowy) wymiar wspólnoty. Przez wspólnotę jest tutaj rozumiane wszystko to co łączy.

W relacji "ja - ty" kształtuje się autentyczna międzyosobowa wspólnota, w jakiejkolwiek postaci czy odmianie, jeżeli "ja" i "ty" trwają we wzajemnej afirmacji transcendentnej wartości osoby (można ją określić także jako godność), potwierdzając to swoimi czynami. Tylko taki układ zasługuje na nazwę "communio personarum” (3).

W pierwszej połowie lat sześćdziesiątych rozpoczął się w Polsce proces określany jako "mała stabilizacja". Wolności kulturalne i polityczne zostały przez władze ograniczone, coraz więcej ludzi zniechęciło się do uczestnictwa w życiu publicznym, wycofała $\mathrm{z}$ niego. Większość ludzi zajęła się codziennymi zabiegami mającymi na celu utrzymanie istniejącego, stale niskiego standardu życia. Wspólnotowe aspekty życia społecznego zaczęły zanikać, a postawy indywidualistyczne stały się coraz bardziej popularne. Cooleyowskie "ideały pierwotne" i wartości dominujące w grupach pierwotnych (wspólnotach) zanikały. Społeczności typu stowarzyszeniowego uzyskały przewage nad społecznościami typu wspólnotowego. Co szczególnie istotne, sfera profanum, sfera zwyczajnego, codziennego, świeckiego życia stawała się w doświadczeniu jednostek znacznie ważniejsza niż sfera uświęcona (sacrum). Ten proces postępował mimo krótkich okresów poprawy gospodarczej, 
stymulowanej głównie przez zagraniczne pożyczki. Okresy prosperity miały niewielki wpływ na kulturalne i duchowe życie Polaków. Kryzys ekonomiczny końca lat siedemdziesiątych i całej dekady lat osiemdziesiątych pogorszył jeszcze tą sytuację. Duchowa "deprawacja" dotknęła przede wszystkim młodzież. Szkoły zbiurokratyzowały się bardzo poważnie. System edukacyjny przestał być kanałem awansu społecznego. Dostęp do dobrych szkół stał się w coraz większej mierze określany przez społeczeństwo - ekonomiczną pozycję rodziców. Dawny etos ciężkiej pracy stracił resztki swego znaczenia społecznego. Życie rodzinne ulega dezorganizacji. Nieformalne grupy rówieśnicze słabły pod wpływem intencjonalnych działań organizacji i instytucji wspomaganych przez państwo. $Z$ drugiej strony dokumenty Vaticanum II kładły w tym czasie nacisk na konieczność odejścia od dotychczasowej biurokratyzacji Kościoła, na konieczność znacznie silniejszego niż dotąd włączenia osób świeckich w kierowanie Kościołem, na konieczność umocnienia życia wspólnotowego.

Kryzys wartości wspólnotowych jest często ważnym źródłem ruchów odrodzenia duchowego. Tak było właśnie w Polsce w omawianym wyżej okresie. Polskie ruchy religijne należą, jak uważa się do tzw. nowych ruchów społecznych. Ruchy te są antymodernistyczne. Odrzucają koncepcję państwa i społeczeństwa opartą wyłącznie na wzroście ekonomicznym. Skupiają uwagę na kwestiach mieszczących się w sferze szeroko rozumianej "nadbudowy" (4).

Typologia grup F. Toenniesa stała się ogromnie trwała. Powraca się do niej często, gdyż wydaje się najtrafniej ujmować i odróżniać grupy wspólnotowe od grup umownych (celowych).

Zapomina się jednak, że typologia Toenniesa określa tylko "typy idealne”, jak gdyby katalogi cech, a podawane przykłady grup zbliżają się mniej lub bardziej do idealnych typów, ale się z nimi nie pokrywają w całości. Wiele grup stanowi w rzeczywistości mieszaninę cech pierwszego i drugiego typu (5).

Socjologowie badali konwersję związaną z uczestnictwem w ruchach społecznych. Pomimo coraz większej zgody, że konwersja jest aspektem ruchu społecznego, daleko jeszcze do zgodności i integracji teorii konwersji z teoriami ruchów społecznych.

Pierwszą grupę stanowią teorie przywoływane dla wyjaśnienia ruchów społecznych, specyficznie religijnych. Opierają się one na klasycznej teorii ruchów sekciarskich, zrywających z konwencjonalną organizacją danego Kościoła. Do tych teorii nawiązują często ci badacze konwersji, którzy uważają, że jest ona zjawiskiem zasadniczo religijnym. Ogólniejsze natomiast teorie ruchów społecznych grupują się w trzy orientacje:

- deprywacyjno - motywacyjną,

- mobilizacji zasobów,

- zachowań zbiorowych w wersji strukturalno - funkcjonalnej oraz w wersji symboliczno interakcyjnej (6).

Wizyty papieża w Polsce unaoczniły pewne niezbędne aspekty Kościoła, które dzięki temu, że ukazały się $\mathrm{w}$ postaci materialnie uchwytnego konkretu, stworzyły szansę zobaczenia się z nadspodziewaną ostrością, kim jesteśmy jako chrześcijanie.

Wyznać należy, że wskutek trudnych do jednoznacznego określenia uwarunkowań, nie lada kłopot sprawia nam przeobrażanie postaw zdominowanych przez tendencje indywidualistyczne na postawy wspólnotowe, o wymowie eklezjalnej. Niepodobna uskarżaćsię na brak teoretycznych wyjaśnień prawdy, że Kościół jest wspólnotą. Wielokrotnie $\mathrm{w}$ rozmaitych zbliżeniach naukowych i popularnych podejmowano ideę, że chrześcijanie stanowią zespolenie ludzi pojednanych z Bogiem i powołanych do życia w tym zespoleniu. Kościół w Polsce powinien poczuć się bogatszy o wyrazistszą świadomość 
eklezjalnej skali życia chrześcijańskiego, wyprowadzić zatem praktyczne wnioski odnośnie projektowania konkretnych form współistnienia. Tym bardziej, że właśnie współistnienie, a nawet kwestia w ogóle wzajemnych odniesień ludzi do siebie, stały się na co dzień zbiorem trudnych do rozwiązania problemów. Jest paradoksem, że w miarę jak zagadnienie współbycia ludzi myślących podobnie lub zgoła przeciwstawnie zdobywa sobie poczesne miejsca i rzeczowe rozwiązania na kartach porozumień i umów, oświadczeń doktrynalnych, napotyka na opór niedojrzałości, słabej psychiki, nie przygotowanej na ich przyjęcie woli jednostek. Zwłaszcza, że nie wykorzystujemy do końca szansy, jaką w tym względzie stwarza ludziom zwykła rozmowa. Jest oczywiste, że ci, którzy w jakiejkolwiek społeczności nie podejmują swoich problemów, z czasem tracą umiejętność rozsądnej wymiany zdań, a gdy okoliczności zmuszają do rozmowy, jest ona nieprecyzyjna, napięta i nade wszystko nerwowa. Najczęściej jednak trudno nam przełamać lęk przed rozmową, w obawie przed ostrą krytyką lub atakiem słownym. Wspomnienie o jakimś zaniedbaniu, o nieświadomym nawet przeoczeniu jakiegoś obowiązku odbieramy często jako bolesne uderzenie $\mathrm{w}$ nasze własne ambicje (7).

Znakiem i narzędziem udziału wiernych świeckich w życiu i misji Kościoła są rozmaite wspólnoty ruchy i stowarzyszenia, które odgrywają szczególną rolę bądź to w kształtowaniu osobowości, bądź w ukierunkowywaniu i wspieraniu działalności apostolskiej. Mówiąc o nowej epoce zrzeszeń papież miał na uwadze nie powszechną wolęczy gotowość do zrzeszania się zwłaszcza, że i w katolicyzmie panuje lenistwo i indywidualizm), ale z faktu, że zjawisko zrzeszania się katolików świeckich ożywiło się i przybrało charakter szczególnie zróżnicowany. Prawdopodobnie nie zwiększyła się liczba katolików, wzrosła natomiast ilość i jakość wspólnot i ruchów ich zrzeszających. Ich rola polega na popieraniu, pobudzaniu i zarazem ulepszaniu osobistej formacji członków oraz ich udziału w życiu wspólnoty kościelnej i ludzkiej (8).

Tylko w małych wspólnotach można konkretnie przeżyć świadomość powołania wspólnoty do szczególnego posłannictwa w świecie. W małych i średnich wspólnotach zwraca się szczególną uwagę na jej przeżywanie. Podkreśla się potrzebę życia we wspólnocie braterskiej, dlatego dąży się do wzajemnego poznania, zwraca się do siebie po imieniu, dąży się do rozwoju bezinteresownej miłości (agape).W takich wspólnotach łatwiej o zacieśnienie relacji międzyosobowych, o uczestnictwo w radościach i cierpieniach oraz problemach współbraci. W małych wspólnotach staje się możliwe przeżycie świadomości szczególnego posłannictwa, misji do spełnienia, poprzez podjęcie i spełnianie konkretnej posługi. Każda wspólnota posiada kogoś, kto jest za nią odpowiedzialny, kto troszczy się o rozwój jej duchowości. Małe wspólnoty kościelne są wspólnotami, które ewangelizują, ale też i wspólnotami, w których się jest ciągle ewangelizowanym (9).

Każda wspólnota ma potrójny cel: kochać człowieka, żyć w łączności i spełniać swoją misję. Każda ma inny styl życia, odmienny regulamin, inną strukturę, odmienne cele na każdy dzień, ale zawsze pozostaje w niej żywa ta sama troska o innych, chęć darzenia miłością, chęć głoszenia wyznawanych wartości wobec wszystkich ludzi. Wspólnota rzeczywiście tworzy jedno, rzeczywiście staje się źródłem promieniowania wówczas, gdy wszyscy jej członkowie zdają sobie sprawę, że do wypełnienia misji trzeba przystąpić bezzwłocznie. Zbyt wielu jest na świecie ludzi pozbawionych nadziei, zbyt wiele wezwań pozostawionych bez odpowiedzi, zbyt wiele osób umierających w samotności. Członkowie wspólnoty żyją w pełni jej rzeczywistości, jeżeli rozumieją, że nie przyszli tam dla siebie lecz by dać siebie innym, Potrzeba aktywności nie oznacza, iż mamy popadać w skrajność, nerwowość - lęk, które są sprzeczne z duchem spokoju, odprężenia ufności. Jest to raczej 
świadomość zła i cierpienia w świecie, ale również świadomość głębi i uniwersalności głoszonych zasad i wartości.

Niektórzy ludzie chcą żyć we wzajemnej bliskości, ale nie bardzo wiedzą, czym to pragnienie umotywować. Każda wspólnota powinna stworzyć własny pomysł na życie, który określałby, dlaczego jej członkowie zdecydowali się być razem i jakie są ich oczekiwania w stosunku do każdego. Oznacza to, że wspólnota zanim powstanie powinna dysponować krótszym, lub dłuższym okresem czasu na przygotowanie wspólnego życia i określenia swoich celów. Im bardziej wspólnota staje się autentyczna i twórcza w poszukiwaniu tego co najważniejsze, oraz w realizacji własnych celów, tym wyraźniej członkowie wspólnoty wezwani są do przezwyciężania własnych słabości i dążą do osiągnięcia jedności. Poczucie przynależności wyraża punkt centralny wspólnotowego życia. Do wspólnoty przychodzimy przecież, żeby być w bliskości $\mathrm{z}$ innymi ludźmi. Życie wspólnotowe nie jest czymś nadzwyczajnym, heroicznym, przeznaczonym dla wąskiego grona. Ono jest dla wszystkich: dla rodzin i grup osób względem siebie nawzajem zaangażowanych. To najbardziej ludzka forma życia forma dająca największą radość, będąca spełnieniem. Każda wspólnota powinna utrzymywać kontakt z innymi. Połączone więzią, wzajemnie się stymulują, wspierają, dodają sobie odwagi, są dla siebie potwierdzeniem. Wspólnota wyizolowana obumiera. Dorastanie do wspólnoty jest drogą nieustannych odkryć. Niewiele możemy powiedzieć o czekającej drodze. Nie odbywamy przecież podróży ze szczegółową mapą, z zaznaczonymi etapami.

Wspólnota oznacza jedność serc, ducha, to siatka relacji, więzi. Ale istnienie więzi wymaga byśmy odpowiadali na wołanie naszych sióstr i braci, szczególnie tych najbiedniejszych, najgłębiej zranionych, abyśmy poczuli się za nich odpowiedzialni. Jest to niewygodne wymaganie. Dlatego łatwo decydujemy się je zastąpić prawem, regulaminem. Łatwiej zachować posłuszeństwo wobec prawa, niż pokochać drugiego człowieka. Dlatego też niektóre wspólnoty kończą się pośród ścisłych regulaminów, zamiast wzrastać w bezinteresowności, w realiach przyjmowania i obdarzania (10).

Przemiany życia i prawa zachodzą równolegle i objawiają się przejściem od związków we wspólnocie do przymierz właściwych wspólnotom, na których miejsce wkraczają następne przymierza właściwe stowarzyszeniu. Związki we wspólnocie są typu rodzinnego, we wszelkich jej postaciach. Jeżeli sięgamy do trzech fundamentalnych elementów wspólnoty (krwi, ziemi i ducha),albo pokrewieństwa, sąsiedztwa i przyjaźni, zauważymy, że wszystkie one występują w rodzinie, jednak elementem konstytutywnym jest pierwszy.

Przymierze właściwe wspólnocie najpełniej przejawia się w przyjaźni. Wspólnota duchowa opiera się na wspólnej pracy, albo powołaniu oraz na wspólnej wierze. Istnieją związki oparte na wspólnocie ducha, nie tylko dobrowolnie podtrzymywane, ale i z własnej woli tworzone. Wszystkie one reprezentują typ i ideę rodziny (11).

Rekrutacja do wspólnoty świeckiej, czy religijnej oraz poddanie się nowemu konstruowaniu rzeczywistości zależy od dwóch warunków: od więzi z jednym lub więcej członkami wspólnoty w związku z uprzednią lub powstałą na nowo relacją osobistą, oraz od nieobecności sieci stosunków przeciwstawnych poza wspólnotą.

Sieć społecznych stosunków stanowią przede wszystkim mikrostruktury, które mają największy wpływ na konwersję i proces budowania wspólnoty, wpływ większy niż predyspozycje poszczególnych osób ją stanowiących. Powody, czy motywy przyłączenia się do wspólnoty wyrastają w tym samym procesie rekrutacji, zaś udział we wspólnocie wymaga dostosowania przez jednostkę swoich interpretacji wydarzeń i doświadczeń ważnych dla działania wspólnoty, do ram interpretacyjnych, jakich dostarcza ideologia wspólnoty (12). 
Rozwojowi polskiej socjologii religii towarzyszy przeprowadzanie wielu interesujących badań szczegółowych, ale niewiele jest prób wyjaśnienia niezwykłego fenomenu polskiej religijności, brak głębszej perspektywy teoretycznej. Nadal stosunkowo mało ukazuje się badań o charakterze jakościowym. Badania ilości jakkolwiek potrzebne, nie są w stanie do końca wyjaśnić badanej rzeczywistości (13).

Religia jest rzeczywistością społeczną dlatego właśnie, że rozgrywa się między osobą, a osobą. Skoro wiadomo, że wypowiedz zachowania (także religijnego) jest wypowiedzeniem czegoś o czymś i kogoś do kogoś. Każde zatem zachowanie które artykułowałoby poza strukturą i naturą wspólnoty nie jest zachowaniem religijnym. Religia staje się w świetle powyższego wyjątkowym sposobem bycia i budowy wspólnotowej natury osoby i osobowej natury wspólnoty ludzkiej (14).

Przyczyna, dla której tak dużo mówi się w ostatnich latach o wspólnocie, o potrzebie tworzenia autentycznych wspólnot, leży nie tylko w chęci dostrojenia się do dzisiejszego klimatu społecznego, ale w coraz większym uświadomieniu sobie konieczności wspólnoty, jako konkretnego wyrazu istnienia większych i mniejszych grup ludzkich. Ruch wspólnoty, obserwowany dziś zwłaszcza w Kościele znajduje się pod częściowym wpływem takich tendencji społecznych jak solidarność, zbliżenie, przyjaźń między ludźmi, co przyczynia się do powstawania coraz bardziej zażyłych stosunków międzyludzkich.

Motywem tych wspólnotowych poszukiwań, obserwowanych od szeregu lat w społeczeństwie - ruch hipisów, izraelskie kibuce, komuny młodzieżowe itp. jest częściowo wynikiem atmosfery osamotnienia i anonimowości, panującej w dużych miastach, właściwej dla epoki społeczeństwa przemysłowego.

Wspólnoty powstające w różnych miejscach starają się wprowadzić jako powszechnie obowiązującą ideę braterstwa, opartą na dzieleniu się dobrami posiadanymi, z uboższymi, postawę otwarcia się na innych oraz przez szacunek zrozumienie i solidarność (15).

Ludzie decydujący się na zawarcie związku małżeńskiego i tworzenie wspólnoty rodzinnej, w przekonaniu, że zaspokoją pragnienie communio i uleczą wewnętrzne (duchowe) rozterki mogą się łatwo zawieść. Tylko przyjęcie drugiego człowieka, ze wszystkimi jego wadami i zaletami, akceptacja jego obecności w naszym życiu pozwoli odkryć właściwy sens wspólnoty rodzinnej.

Własne głębokie zranienia zaakceptujemy dopiero wtedy, gdy odkryjemy, że wspólnota jest miejscem zakorzenienia dla naszej sfery duchowej, miejscem gdzie czujemy się "u siebie". Takie zakorzenienie nie ma nic wspólnego z zamykaniem się w sobie, nie służąc wygodzie. Wspólnota nie służy sama sobie, lecz innym ludziom zwłaszcza ubogim, jak również Kościołowi i społeczeństwu. Ma charakter misyjny (przekazuje nadzieję i miłość innym ludziom).

W tym rozumieniu posiada ona także charakter polityczny.

Może istnieć naprawdę tylko wtedy, kiedy staje się dla ubogich źródłem dla niej, kiedy między nią a ubogimi istnieje obieg życia i miłości.

Życie wspólnotowe zyskuje przez to szerszy wymiar, łączy członków wspólnoty obejmując mieszkańców całej społeczności lokalnej, biednych i wszystkich, którzy chcą podzielać jej nadzieje.

Staje się miejscem pojednania i przebaczania, gdzie każdy czuje opiekę innych i sam chce się nimi opiekować, miejscem przyjaźni ludzkiej, którzy zdają sobie sprawę ze swej słabości, lecz jednocześnie wiedzą, że zaznają miłości i przebaczenia.

Świętowanie oznacza, że poza cierpieniem i śmiercią, nienawiścią i uciskiem, niesprawiedliwością i winą, istnieją "wieczne gody”, spotkanie dające pełnię, zaspokojenie 
głodu nieskończoności. Warto więc kontynuować wspólnotową drogę, bo nadzieja nie zginęła (16).

Budowanie i strzeżenie jedności wspólnoty jest zadaniem wszystkich jej członków. Ponieważ wszyscy są powołani, by ją kształtować i zachowywać każdego dnia przede wszystkim przez miłość, która jest "więzią doskonałości".

Istnienie różnych instytutów i społeczności będących wyrazem partykularyzmu, nie tylko nie powinno przyczyniać się do powstawania nieporozumień, lecz powinno nadawać jedności ( wspólnocie) wewnętrznego zróżnicowania, które jest właściwością communio (17).

Jeżeli osoba wstępuje do określonej wspólnoty religijnej, winna w niej spotkać Kościół. Wspólnota jest bowiem Kościołem w skali mikro (18).

Wspólnota ujmuje Kościół uniwersalistycznie i zarazem stanowi jego konkretną realizację w kontekście lokalnym. Ujawnia najgłębsze zjednoczenie wewnętrzne i zewnętrzne, przypieczętowane sakramentem, urzędem i strukturą kościelną.

Wspólnota ożywia stosunki interpersonalne, odpowiada najgłębszym potrzebom naszych czasów. Pojęcie to odpowiada naszemu rozumieniu Kościoła i chce ukazać jego rzeczywistość jako wspólnotę (19).

Kościół bogaty w posługi, będący wspólnotą wspólnot, pozostaje aktualnie w sferze duchowej. Oczom zgromadzonych wiernych, nadal ukazuje się obraz sumy jednostek, bez organicznego zróżnicowania. Struktura pośrednictwa miedzy kapłanem, a wspólnotą jest ukształtowana nieczytelnie. Ciągle istnieje krańcowy przeskok od całości do jednostki z pominięciem podstawowego prawa organizmu, który brany w całości, nie jest tylko sumą komórek, lecz posiada wyspecjalizowane tkanki, które wspólnie tworzą poszczególne części organizmu (20).

Wiedząc, że istnieje taka potrzeba i brak wśród wiernych, każda wspólnota (zwłaszcza kościelna) powinna wrócić do prawdziwych rekolekcji zamkniętych, podjęcia przez kapłanów prawdziwego kierownictwa duchowego (nie tylko z okazji spowiedzi), ale w różnych formach duszpasterstw i stowarzyszeniach.

Liturgia jako taka powinna stać się czasem przeżywania wspólnoty z ludźmi i Bogiem. Kościół, jakkolwiek prawdziwy, nie może polegać zupełnie na swej prawdziwości, gdyż nie jest kościołem dla Boga, ale dla ludzi. Inaczej te potrzeby ludzkie zaspokoją nieprawdziwe, ale bardziej elastyczne sekty (21).

Operatywny opis sekty mógłby brzmieć następująco: wspólnota, którą $\mathrm{z}$ chrześcijaństwem łączy przekaz wiary i specyficzna interpretacja tego przekazu oraz istotne dla siebie pozabiblijne źródła prawdy i Objawienie, które z reguły odrzucają ekumeniczny dialog. Jako cechy dla sekt najbardziej typowe wymienia się przede wszystkim:

- wybujała świadomość wybraństwa, w myśl której tylko członkowie danej sekty mogą osiągnąć życie wieczne, stąd radykalizm i fanatyzm członków sekt,

- indywidualistyczne i fundamentalistyczne rozumienie Biblii, izolujące poszczególne passusy z kontekstu oraz odrzucające wszelki urząd nauczycielski Kościoła w tej materii. Obok Pisma św. często na pierwszym miejscu są stawiane elementy piśmiennictwa założyciela sekty,

- radykalne dystansowanie się od Kościoła, szczególnie katolickiego i zapiekła wrogość w stosunku do idei papiestwa,

- są to wspólnoty młode, a ich początki datują się zazwyczaj na niewiele ponad sto lat. Stąd bierze się ich niemała popularność, a nawet sukcesy w pozyskiwaniu członków. 
Sekty bezlitośnie obnażają deficyty życia religijnego w naszych parafiach. Na pierwszym miejscu należy wymienić małe grupy. Wierni często nie znają nawet swojego proboszcza (parafie wielkomiejskie), co jest rzeczą nie do pomyślenia w sektach. Bliskość i atmosfera zaufania, wobec ziejącej w większości kościołów nudy, wielu wiernych skłania do bezszelestnego przechodzenia na inne wyznanie. Serdeczność i ciepło - po Mszy św. wierni rozchodzą się szybko, w pojedynkę do domów, na pozostanie chwilę przed kościołem zazwyczaj nie ma miejsca, gdyż uformowała się już następna „fala” parafian oczekujących na kolejną Eucharystię.

Znane i ciągle cytowane jest zdanie wielkiego teologa K. Rahnera o sytuacji współczesnego chrześcijaństwa: „Chrześcijanie staną mistykami, albo chrześcijaństwa nie będzie w ogóle”. Klarowne żądania - chrześcijanie czują się w twardej rzeczywistości naszych czasów pozostawieni sobie samym.

Topnieje liczba autorytetów, zdecydowane i niedwuznaczne żądania pojawiają się bardzo rzadko (22).

Prawdziwą wspólnotę tworzą osoby, które naprawdę spotykają się w dobrych relacjach osobowych, w wierze i miłości. Na pierwszym miejscu są tam osoby i ich relacje, potem zadania, które należy wykonać i sprawy osobiste. Nie ma prawdziwej wspólnoty tam, gdzie pomija się relacje osobowe (23).

Wraz z rozkwitem New Age i nowych ruchów religijnych, wszystko dzieje się jakby odtąd doświadczenie chrześcijańskie odsunięte zostało na margines.

Wstawione między medytację transcendentalną, miałoby reprezentować w najlepszym przypadku psychotechnikę. Istnieje wielka potrzeba świadectwa o życiu wspólnotowym. Świadectwo zbiorowe narodu polskiego, filipińskiego, czy południowoafrykańskiego pozostaje w pamięci jako manifestacja wyzwoleńczej nauki chrześcijańskiej. Każdy wierzący, każda grupa, ruch, wspólnota może brać udział na swoją miarę, zgodnie z możliwościami, w kontekście sobie właściwym w dawaniu świadectwa (24).

Trzydziestolecie jakie upływa od zakończenia obrad Vaticanum II zaowocowało, zwłaszcza w Polsce, dalszym umocnieniem Kościoła, ożywiło życie parafialne, rozwija się ruch wspólnotowy. Jednak mimo tego, niewiele udaje się zrobić, by przezwyciężyć różnicę między życiem codziennym, a religią. Wartości, ideały moralne wciąż w zbyt małym stopniu przenikają do praktyki życia codziennego (praca, rodzina, życie społeczne).

Przy stosunkowo masowych praktykach i manifestacjach religijnych, ta dysproporcja jest szczególnie zawstydzająca oraz budząca niepokój co do jakości religijności. W tym zakresie sobór nadal czeka na swoją realizację (25).

Należy podkreślić, że polemikę między Kościołem, a sektami przeprowadza się częstokroć na płaszczyźnie zupełnie błędnej, a przede wszystkim wyobcowanej z życia.

Niewiele się przez to uzyskuje, gdy postawi się pod pręgierz, niektóre śmieszne twierdzenia lub niedorzeczne interpretacje tekstów Pisma św. przez poszczególne sekty.

Ważniejsze jest dokładne poznanie sił religijnych danej sekty. Jeżeli na przykład „Świadkowie Jehowy” wykazują się męstwem i stałością przekonań, to te przymioty posiadają o wiele większą siłę zjednywania zwolenników, niż dogmatyczne zbijanie poszczególnych zarzutów (26).

Mimo powyższych braków w wielu parafiach szczęśliwie rozwija się dialog świeckich i duchownych, co korzystnie wpływa na współczesne życie parafii, ożywia ją i sprzyja budowaniu autentycznych wspólnoty.

Akcje duszpasterskie prowadzone w wielu parafiach mają charakter przejściowy i nie prowadzą do odnowy całości życia parafialnego. Jednak kapłani starają się tam nie zniechęcać i podejmować zróżnicowane działania. Świeccy co prawda nie odnaleźli jeszcze 
w pełni miejsca swojego bezpośredniego zaangażowania w Kościele, duża część świeckich czuje się usatysfakcjonowana tym stanem rzeczy i stara się podejmować inicjatywy wychodzące naprzeciw potrzebom wiernych. Znajomość nowego obrazu Kościoła jest nadal niewystarczająca wśród wiernych. Najważniejszym zadaniem w świetle tego staje się przełożenie soborowej eklezjologii na konkretne działania, budowanie wspólnot w parafiach (kościele lokalnym). Pomocą ma być także opublikowanie polskiej wersji Katechizmu Kościoła Katolickiego (27).

W Polsce, aktualnie wielorako skłóconej, chrześcijanin powinien dawać lekcję, jak ponad podziałami można i powinno się budować wspólnotę.

Szukać należy tego co łączy. Ważne przy tym jest, aby koniecznej krytyki dokonywać z miłości do swojej wspólnoty.

Najskuteczniejszym sposobem poddawania krytyce określonej wspólnoty przez jednostkę, jest jej osobisty przykład. Krytyce słownej nie można przypisywać zbyt dużej wagi. Bardziej wiarygodna jest krytyka przez czyn, przez prawdziwe, ewangeliczne życie chrześcijanina.

Wspólnoty kościelne winny mieć charakter wspólnot otwartych gotowych przyjąć wszystkich, którzy poszukują Prawdy.

W Kościele nikt nie jest obcy. Na potępienie zasługuje grzech nie grzesznik. Bycie we wspólnocie kościelnej ma charakter dynamiczny, żywy, dostrzegający każdego z pozostałych członków. Wspólnotę mogą tworzyć tylko osoby, które afirmują siebie i są zdolne stać się darem dla innych.

Poprzez bezinteresowny dar z siebie osoba prawdziwie żyje we wspólnocie i dla wspólnoty. Wspólnotę buduje się także poprzez pracę. Owoce pracy, jeżeli służą dobru wspólnemu - pozwalają osobie pełniej uczestniczyć w życiu wspólnym. Osoba ludzka pełniej widzi siebie i rozumie miejsce we wspólnocie podejmując w niej konkretną posługę w relacji do innych osób. Drugi człowiek jest apelem skierowanym do nas samych (28).

Poznanie się uczestników jest pierwszym krokiem budowania wspólnoty. To co się szuka, to pewien stopień szczerości i autentyczności. Prawdziwe zaufanie, jako owoc tego etapu, wymaga aby osoby znały się, aby wiedziały kim jest osoba, z którą tworzą daną wspólnotę. Wymaga to wzajemnej tolerancji i akceptacji każdego, bez wyjątku. Osoby obecne, zjednoczone przez wzajemne zaufanie. Dalszy rozwój prowadzi do określenia wzajemnych relacji we wspólnym dziele, udziału, zdefiniowania swojego zaangażowania i odpowiedzialności. W tym momencie rodzi się duch wspólnoty. Wspólnota zaczyna odkrywać wartości, które ją gromadzą, staną się one później punktem wyjścia w ich misji.

Świadomość siebie, która nie jest pesymistyczna lecz optymistyczna, mobilizuje do wzrostu i pracy. W tym momencie wspólnota jest w stanie przyjąć na siebie odpowiedzialność, ukazując jednocześnie swoją dojrzałość.

Umie ocenić swój postęp duchowy, kontrolować swoje działania, regulować spięcia negatywne, pogłębiać relacje z innymi wspólnotami, które ją otaczają (29).

Stworzenie wspólnoty niemożliwe jest bez pracy, cierpliwości, czasu i miejsca, gdzie osoby stoją w prawdzie, rozpoznając własne talenty, gdzie odkrywają swoje zadania, którym warto poświęcić nasz czas i energię (30).

Podkreślając rolę jaką w budowaniu wspólnoty odgrywa liturgia, nie sposób pominąc roli słowa drukowanego i mówionego w tym dziele oraz podejmowania diakonii (służby na jej rzecz), w duchu caritas (31).

Diakonijność we wspólnocie osiąga pełnię, gdy wartości przeżywane stają się własnością całej wspólnoty. Przykładem tego mogą być chociażby piosenki. 
Był czas, gdy współczesne piosenki religijne były śpiewane nie tylko w grupach oazowych. Grupy te stały się głównym narzędziem przenikania tych nowych form muzycznych do parafii.

Dziś wiele zostało już przyswojone przez poszczególne kościoły partykularne. Na tym odcinku Oaza „umarła”, aby narodzić się na nowo jako odmienna jakość we wspólnocie parafialnej. Proces ten postępuje obecnie bardzo wolno. Nie można go jednak nie zauważać. Dziś przed Oazami staje bardzo trudne zadanie przygotowania do posługi liturgicznej licznych zespołów mężczyzn i kobiet. $Z$ czasem stanie się to czymś zwyczajnym w każdej parafii (32).

Można przy tym dodać, że nie wszystkie grupy nazywane Oazą można utożsamiać z Ruchem „Światło - Życie”. Często takie „oazy” wybierają dowolne elementy, które im odpowiadają z programu Ruchu, nie realizują w pełni celów zamierzonych przez tenże program. Każdy Ruch ma prawo do strzeżenia swego charyzmatu, który ma cechy niepowtarzalności (33).

Podjęty temat rozprawy miał na celu ukazanie sposobu w jaki wspólnoty parafialne ruchów odnowy realizują zadanie jednoczenia społeczności lokalnej w skali mezostrukturalnej, która zawierałaby w sobie elementy makro i mikrostruktury.

W świetle powyższych wywodów teoretycznych oraz przeprowadzonych badań empirycznych metodą obserwacji uczestniczącej, stwierdzono że proces taki ma miejsce głównie poprzez zjawisko konwersji i podejmowania konkretnej posługi (diakonii) na rzecz małej wspólnoty. Nieodłącznym elementem takich przemian staje się internalizacja proponowanych postaw w życiu codziennym.

Różnorodność zagadnień nastręczała wiele trudności autorowi niniejszej pracy. Wiązały się one przede wszystkim z kwestią metodologiczną, czyli rozdzieleniem porządku naturalnego i nadprzyrodzonego w pojęciu wspólnoty (zwłaszcza religijnej). Dla wyraźnego podkreślenia rzeczywistości w jakiej poruszał się badacz, często używano słów pokrewnych (communio, koinonia). Selektywne przedstawienie materiału źródłowego miało na celu zapewnienie większej przejrzystości pracy, bez jej merytorycznego zafałszowania.

Wspólnota jako kategoria socjologiczna czy religijna pozostaje nadal niezastąpionym wzorem doskonałej struktury społecznej, o wielorakim zasięgu.

Uczestnictwo w niej oparte na zasadach odpowiedzialności, dobrowolności i miłości, prowadzące do trwałej konwersji i internalizacji proponowanych postaw, postulowana konieczność uczestnictwa oraz diakonii (służby) we wspólnocie i na jej rzecz, jest skutecznym antidotum na marazm duchowy dzisiejszego świata.

\section{Przypisy do rozdziału VI}

1. S. Clark: Budowanie wspólnot chrześcijańskich, Wrocław 1994, s. 24-55.

2. E. Pleń (red): Animator grupy młodzieżowej, Warszawa 1994, s. 127-129.

3. K. Wojtyła: Osoba, podmiot, i wspólnota, w: Roczniki Filozoficzne KUL 24/1976, s. $28-29$

4. J. Mucha, M. Żaba: Odrodzenie religijne, czy substytut polityczny, w: Socjologia wychowania t. X Toruń 1993, s. 58-59. 
5. J. Turowski: Socjologia, Lublin 1993, s. 109.

6. R. Turner, L. Killian: Collective Behavior, New York 1987, s. 220-240.

7. T. Sikorski: Słowo i metanoia, w: Być człowiekiem i chrześcijaninem (red. B. Bejze), Warszawa 1980, s. 122-124.

8. R. Dudek: Być świeckim, Kraków 1993 s. 46-47.

9. A. Żądło: Jaka parafia na nasze czasy, Kielce 1994, s. 25.

10. J. Vanier: Wspólnota miejscem radości i przebaczenia, Warszawa 1991, s. 103-125.

11. F. Toennies: Wspólnota i stowarzyszenie, Warszawa 1988, s. 263.

12. E. Hałas: Konwersja, Lublin 1992, s. 123-124.

13. Z. Nosowski: Triumf i niepewność, w: Więź 7-8/91, s. 54.

14. A. Wójtowicz: Przesłanki socjologicznych kategorii kultury religijnej, w: Studia Religioznawcze 19, Kraków 1984, s. 245-248.

15. S. Movilla: Od katechumenatu do wspólnoty, Warszawa 1990, s. 173-176.

16. J. Vanier: op. cit., s. 374-376.

17. List do biskupów Kościoła o niektórych aspektach Kościoła pojętego jako komunia, Krościenko 1993, s. 11-12.

18. E. Staniek: Bogactwo tajemnicy Kościoła, Kraków 1990, s. 28.

19. B. Biela: Kościół - wspólnota, Katowice, 1993, s. 192.

20. S. Szczepaniec: Pytanie o posługi liturgiczne, Lublin 1989, s. 8-9.

21. S. Pyszka: Kościół Katolicki w obliczu sekt, Kraków 1990, w: Horyzonty wiary 3/90, s. 14.

22. A. Skowronek: Sekty, wyzwanie, czy zgorszenie, Kraków 1992, s. 8-20.

23. J. Mikrut: Seminarium odnowy w Duchu św., Krościenko 1994, s. 11.

24. I. Dec (red) Złudzenia Nowej Ery, Wrocław 1993, s. 146.

25. J. Wołkowski: Dwa wektory odnowy, w: Życie katolickie 12/85, s. 58.

26. W. Gruehn: Religijność współczesnego człowieka, Warszawa 1966, s. 451.

27. M. Nowak: O nową wizję parafii, Warszawa 1993, s. 119-121.

28. R. Kuligowski: Osoba ludzka we wspólnocie, w: Formacja liderów parafialnych kół synodalnych, Warszawa 1993, s. 39-43.

29. J. Gołębiewski: Wybrane zagadnienia z teologii wspólnoty, w: Szkolenie animatorów parafialnych kół synodalnych, Warszawa 1993, s. 12-14.

30. Moja parafia, w: Magazyn Słowo, dziennik katolicki, 4/15/94, s. 11. 
31. A. Przybecki: Urzeczywistnianie się Kościoła w środowisku akademickim, Poznań 1986, s. 111-116.

32. S. Szczepaniec: Pytanie o charyzmat wspólnot odnowy, Lublin 1990, s. 38.

33. M. Ostrowski: Wychowanie do uczestnictwa w życiu Kościoła poprzez Ruch "Światło Życie", w: Horyzonty wiary 6/91, s. 57.

\section{BIBLIOGRAFIA}

1. P. Abell: Modele w socjologii, Warszawa 1975.

2. F. Adamski: Socjologia małżeństwa i rodziny, Warszawa 1984.

3. F. Adler: The Value Concept in Sociology, w: The American Journal of Sociology 62(3) (1956).

4. Ad Gentes Divinitus, w: Dokumenty Soboru Watykanskiego II, Poznań 1986.

5. K. Ajdukiewicz: Język i poznanie, Warszawa 1985.

6. Arystoteles: Polityka, Warszawa 1969.

7. Augustyn: O Panstwie Bożym, Warszawa 1977.

8. R. Bales, P. Slater: Role differentation small decision making groups, Glencoe 1955.

9. A. Ballestrero: Wspólnota z Bogiem, Kraków 1985.

10. P. Berger: Sekularyzacja, a problem wiarygodności religii, w: Socjologia religii Kraków 1984.

11. B. Biela: Kościół - wspólnota, Katowice 1993.

12. F. Blachnicki: Kościół jako wspólnota, Krościenko 1981.

13. P. Blau: Exchange and Power in Social Life, New York 1964.

14. H. Blumer: Symbolic Interactionism, New Jersey 1969.

15. A. Borowski: Konwersja w instytucjach totalnych, Szczecin 1992, maszynopis powielany.

16. A. Borowski: Metoda obserwacji uczestniczącej w badaniach z zakresu socjologii religii, w: Studia Sociologica, t. 5, Szczecin 1993.

17. A. Borowski: Więź społeczna w parafii, potrzeba budowania jedności, Szczecin 1992 (maszynopis powielany).

18. Z. Borowik: Wspólnota państwowa w nauczaniu S. Wyszyńskiego, w: Życie Katolickie 7-8/84.

19. I. Bokwa: Kościół jako wspólnota, w: Przegląd Powszechny 1/93.

20. K. Brodzki, J. Wojna: Oazy, Ruch „Światło - Życie” Warszawa 1988. 
21. D. Bromley, J. Richardson (red): The Brainwashing, New York 1983.

22. M. Brzozowski: Solidarność, to imię społecznej miłości, w: Ethos, 11-12/90.

23. C. Buczek: Kategoria wartości w badaniach przemian społecznych, w: Studia Sociologica, Szczecin 1992.

24. J. Bukowski: Zarys filozofii spotkania, Kraków 1987.

25. R. Caldera: Co to jest chrześcijańska demokracja, Poznań 1990.

26. F. Capra: Jedność wszystkich rzeczy, w: Nomos 1/92.

27. H. Carrier: Rola grup odniesienia w integracji postaw religijnych, w: Socjologia religii Kraków 1984.

28. W. Chaim: Psychologiczna analiza religijności niespójnej, Lublin 1991.

29. J. Charytański: W kręgu zadań i treści katechezy, Kraków 1992.

30. B. Chełstowski: Pojęcia, wskaźniki, metody i korelaty integracji grupy w literaturze socjometrycznej, w: Studia Socjologiczne 1/66.

31. B. Chmielewska: Kilka refleksji na temat więzi lokalnych i regionalnych, w: Roczniki Koszalińskie 1975.

32. E. Ciupak: Kult religijny i jego podłoże, Warszawa 1965.

33. E. Ciupak: Religijność młodego Polaka, Warszawa 1984.

34. S. Clark: Budowanie wspólnot chrześcijańskich, Wrocław 1994.

35. C. Cooley: Social Organization, New York 1964.

36. P. Cordes: Ducha nie gaście, Gorzów Wlkp 1990.

37. L. A. Coser: The Functions of Social Conflict, New York 1964.

38. M. Crozier: The Relationship between micro, and macrosociology, w: Human Relations $25 / 72$.

39. C. J. Cyman: Działalność apostolska sióstr, a integracja ze wspólnotą zakonną, Warszawa 1990.

40. K. Czekaj: Zastosowanie obserwacji uczestniczącej i wywiadu z informatorem ekspertem społecznym do badania społeczności lokalnych, w: Społeczności lokalne regionu Górnego Śląska, Wrocław 1987.

41. G. Daneels: Jak ewangelizować zsekularyzowaną Europę, w: Orientacje 4/14, Warszawa 1992.

42. I. Dec (red): Złudzenia Nowej Ery, Wrocław 1993.

43. J. Dewey: Demokracja i wychowanie, Wrocław 1972.

44. T. Dezamy: Kodeks wspólnoty, Warszawa 1977. 
45. T. Doktór: Nowe ruchy religijne i parareligijne w Polsce, w: Euhemer 4/91.

46. J. Downton: An Evolutionary Theory of Spiritual Conversion on Commitment, w: Journal for the Scientific Study of Religion 4 (1980).

47. Drugi Polski Synod Plenarny, Poznań 1991.

48. R. Dudek (red): Być świeckim, Kraków 1993.

49. J. Duke: The Principle of Emergence and Levels of Sociological Analysis, Bringham Young University 1970.

50. W. Durka: Statystyczne wskaźniki integracji, w: Roczniki socjologii morskiej, Szczecin 1991.

51. E. Durkheim: Les Formes elementaires de la vie religieuse, Paris 1960.

52. M. Eliade: Methodological Remarks of the Study of Remarks of the Study of Religious Symbolism, London 1959.

53. J. H. Fichter: Social Relations in the Urban Parish, Chicago 1954.

54. Francja - ku wspólnocie Ludu Bożego, w: Życie Katolickie 2/84.

55. Z. Freud: Psychologia zbiorowości i analiza ego, Warszawa 1975.

56. M. Furstenberg: Religionssoziologie, Tuebingen 1961.

57. T. Gadacz: Kościół jest naszym wielkim wspólnym dobrem, Znak 11/91.

58. Gaudium et Spes, w: Sobór Watykański II (dokumenty), Poznań 1986.

59. T. Geiger: Fuhren and Folgen, Berlin 1928.

60. O. Gierke: Natural Law and the Theory of Society, Boston 1957.

61. L. Giussani: Śladami chrześcijańskiego doświadczenia, Warszawa 1988.

62. E. Goffman: Asylums, Chicago 1968.

63. M. Gogacz, On ma wzrastać, Warszawa 1990.

64. J. Gołębiewski: Wybrane zagadnienie z teologii wspólnoty, w: Materiały Synodalne diecezji Warszawsko - Praskiej, Warszawa 1993.

65. Z. Gostkowski: Analizy i próby technik badawczych w socjologii, Warszawa 1990.

66. A. Gregori: Comunidades Eclesiais de Basse, Rio Petropolis 1973.

67. F. Grucza: Terminologia, w: Teoretyczne podstawy terminologii, Wrocław 1991.

68. W. Gruehn: Religijność współczesnego człowieka, Warszawa 1966.

69. S. Grygiel: Tożsamość poczętego dziecka, w: Znaki czasu 17/90.

70. H. Grzymała - Moszczyńska: Nowe Ruchy Religijne, w: Oświata i wychowanie, I/85. 
71. H. Grzymała - Moszczyńska: Psychologia religii, Kraków 1991.

72. E. Hałas: Konwersja, Lublin 1992.

73. A. P. Hare: Wielkość grupy, a consensus, w: Elementy mikrosocjologii, cz. II (red. J. Szmatka) Kraków 1992.

74. B. Haring: Macht und Ohnmacht der Religion, Salzburg 1956.

75. A. Hatliński (red): Nauka Soboru Watykańskiego II - go Poznań 1986.

76. E. Hatch: Theories of Man and Culture, New York 1973.

77. I. Hernandez: Caracters psicosociologicos de la Comunidad, w: Actualidad Catequetice 1979.

78. G. Hegel: Wykłady z filozofii dziejów, Warszawa 1958.

79. J. Higley: Elites in Australia, London 1979.

80. G. A. Hillery: Deffinitions of Community, w: Rural Sociology 20/55.

81. M. Hirszowicz: Wstęp do socjologii organizacji, Warszawa 1967.

82. J. Höffner: Chrześcijańska Nauka Społeczna, Kraków 1989.

83. G. C. Homans: Social Behavior, New York 1974.

84. F. Houtart: Socjologia parafii jako zgromadzenia Eucharystycznego, w: Ludzie, wiara Kościół (red. B. Cywiński), Warszawa 1966.

85. B. Hume: Spotkanie Jasnogórskie, w: Jasna Góra 10/92.

86. E. Husserl: Logische Untersuchungen, Halle 1913.

87. W. Jacher: Kategoria integracji społecznej, w: Studia Sociologica, Szczecin 1992.

88. Jan Paweł II: Christifideles Laici, w: Chrześcijanin a Współczesność 2/89.

89. Jan Paweł II: Posłanie do G. V. Coyne’a, w: Znak - Idee, t. 5, Kraków 1993.

90. Jan Paweł II: Przemówienie do ludzi morza, Gdynia, w: Znak I - 2/87.

91. B. Jałowiecki: Rozwój Lokalny, Warszawa 1989/ 92. A. Jasińska, M. Siemińska, Wzór osobowości, w: Oświata dorosłych 10/79.

93. R. Jaworski: Psychologiczne korelaty religijności personalnej Lublin 1989.

94. H. Juros: Nowe zadania Kościoła w Polsce, w: Przegląd Powszechny I/93.

95. F. Kampka: Zasada solidarności, a związki zawodowe, w: Ethos 11 - 12/91.

96. I. Kant: Krytyka władzy sądzenia, Warszawa 1986.

97. J. Karpiński: Przyczynowość w badaniach socjologicznych, Warszawa 1985.

98. J. Kłoczowski: Katolicy Polscy wobec zadań dnia dzisiejszego, Znak 6/91. 
99. A. Kłoskowska: Małe grupy społeczne, a społeczeństwo masowe, w: Kultura i społeczeństwo 3/1959.

100. A. Kłoskowska: Zagadnienie małych grup w socjologii, w: Przegląd socjologiczny $12 / 58$.

101. Konstytucja duszpasterska o Kościele w swiecie współczesnym, w: Dokumenty Soboru Watykańskiego II, Poznań 1986.

102. S. Krajski: Miejsce Kościoła i zadania dla elity katolickiej w Polsce, w: Emaus, 14/92.

103. A. L. Kroeber: Istota kultury, Warszawa 1973.

104. M. Kuhn: Major Trends in Symbolic Interaction Theory, w: Sociological Quarterly 5/64.

105. R. Kuligowski: Osoba ludzka we wspólnocie, w: Formacja liderów parafialnych kół synodalnych, Warszawa 1993.

106. W. S. Landecker: Types of Integration and their Measurement, New York 1962.

107. F. Lenoir: Nowe wspólnoty, Warszawa 1993.

108. L. Leopold: Das Prestige, Berlin 1916.

109. A. Lepa: Parafia wielkomiejska jako środowisko wychowawcze, w: Dziś i jutro parafii, Łódź 1991.

110. M. Libiszowska - Żółtkowska: Postawy inteligencji wobec religii, Warszawa 1991.

111. M. Libiszowska - Żółtkowska: Socjologiczne aspekty konwersji religijnej, w: Euhemer 4/91.

112. List do biskupów Kościoła o niektórych aspektach Kościoła pojętego jako komunia, Krościenko 1993.

113. C. Lubich: Klucz do jedności: Poznań 1989.

114. Lumen Gentium: w, Dokumenty Soboru Watykańskiego II, Poznań 1986.

115. Ludzie, wiara Kościół (red. B. Cywiński). Warszawa 1966.

116. H. Łuczak: Wspólnota zbawienia Warszawa 1990.

117. J. Majka: Katolicka Nauka Społeczna, Warszawa 1988.

118. J. Majka: Filozofia społeczna, Wrocław 1982.

119. W. Makarczyk: Studia nad aparaturą pojęciową socjologii, Warszawa 1991.

120. J. Mariański: Kierunki badań polskiej socjologii religii w latach osiemdziesiątych, w: Życie Katolickie 9/89-1/90.

121. J. Mariański: Religijność w procesie przemian, Warszawa 1991.

122. J. Mariański: Kościół w społeczeństwie przemysłowym, Warszawa 1983.

123. J. Mariański, Żyć parafią, Wrocław 1984. 
124. J. Mariański: Kondycja religijna i moralna młodych Polaków, Kraków 1991.

125. J. Mariański: Kontrowersje wokół roli świeckich w parafii, w: Życie Katolickie 7/87.

126. K. Marks, F. Engels: Święta Rodzina, w: Pisma Warszawa 1961.

127. D. Maszczyk, A. Radziewicz: Metody badań w naukach społecznych, Katowice 1979.

128. R. Mayntz: Wprowadzenie do metod socjologii empirycznej, Warszawa 1985.

129. M. Miazga: Kształtowanie się społeczności w mieście o szybkim rozwoju, w: Studia Socjologiczne t. XXXV 1985.

130. J. Michalik: Nie wierzę w konflikt pokoleń, w: Znaki czasu 17/90.

131. R. Michels: Political Parties, Glencoe 1915.

132. J. Mikrut: Seminarium odnowy w Duchu św., Krościenko 1994.

133. C. W. Mills: Elita władzy, Warszawa 1961.

134. G. Missalowa: Francuski socjalizm utopijny, w: W stulecie Wiosny Ludów, Warszawa 1951.

135. M. Misztal: Pojęcie wartości w socjologii, w: Studia socjologiczne 4/75.

136. Moja parafia, w: Magazyn Słowo- dziennik Katolicki, 4/15/94.

137. A. Morawska: Socjologia a odnowa, w: Znak 6/64.

138. G. Mosca: Historia doktryn politycznych od starożytności do nowych czasów, Warszawa 1939.

139. J. Moreno: Note on Cohesion in Social Groups, w: Sociometry 13/51.

140. S. Movilla: Od katechumenatu do wspólnoty, Warszawa 1990.

141. J. Mucha: Cooley, Warszawa 1992.

142. R. Mucchielli: La dynamigaue des groupes, Paris 1976.

143. Nauka o Kościele i miejscu Matki Bożej w Kościele, w: Drugi Polski Synod Plenarny, Poznań 1991.

144. R. Nisbet: The Social Philosophers, New York 1973.

145. R. Nisbet: Conservatism and Sociology, w: American Journal of Sociology 58(2)(1952).

146. Z. Nosowski: Między tradycją, a wyborem, w: Spotkania 13/92.

147. M. Nowaczyk: Nowe ruchy religijne, w: Euhemer 4/91.

148. M. Nowak: Kościół, wspólnota dla wszystkich, w: Znak 9/90.

149. M. Nowak: O nową wizję parafii, Warszawa 1993.

150. J. Olbrycht: Spoistość małej grupy społecznej. Katowice 1987. 
151. S. Olejnik: Teologia moralna, Warszawa 1988-1993, t. 1-7.

152. M. Ossowska: Normy moralne, Warszawa 1970.

153. S. Ossowski: Więź społeczna i dziedzictwo krwi, Warszawa 1966.

154. S. Ossowski: Z zagadnień psychologii społecznej, w: Dzieła t. 3, Warszawa 1967.

155. S. Ossowski: O Ojczyźnie i narodzie, Warszawa 1984.

156. M. Ostrowski: Wychowanie do uczestnictwa w życiu Kościoła poprzez Ruch „ŚwiatłoŻycie”, w: Horyzonty wiary, 6/91 Kraków 1991.

157. E. Ozorowski: Kościół, Wrocław 1984.

158. J. Pająk: Zakład pracy w systemie integracji społecznej, w: Studia Sociologica, Szczecin 1992.

159. A. Paluch: Mistrzowie antropologii społecznej, Warszawa 1990.

160. V. Pareto: Uczucia i działania, Warszawa 1994.

161. T. Parsons: Societies, New York 1966.

162. Z. Pasek: Krakowska wspólnota modlitewna „Nowe życie” jako przejaw charyzmatycznej odnowy Kościoła, w: Studia Religiologica, Kraków 1986.

163. A. Perzyński: Parafia w świetle teologii kościoła lokalnego, w: Dziś i jutro parafii, Łódź 1991.

164. W. Piwowarski: Blaski i cienie polskiej religijności, w: Oblicza katolicyzmu w Polsce, Warszawa 1984.

165. W. Piwowarski: Religijność wiejska w warunkach urbanizacji, Warszawa 1971.

166. E. Pleń (red): Animator grupy młodzieżowej, Warszawa 1994.

167. Platon: Państwo, Warszawa 1958.

168. A. Podgórecki: Socjotechnika Warszawa 1970.

169. E. Podrez: Człowiek, byt, wartość, Warszawa 1989.

170. E. Podrez: Osobowy i społeczny aspekt natury ludzkiej, w: Życie Katolickie 1/85 .

171. M. Przeciszewski: Pielgrzymka nadziei, w: Spotkania 18/91.

172. M. Przeciszewski: Wspólnota wspólnot, w: Spotkania 27/91.

173. A. Przybecki: Urzeczywistnianie się Kościoła w środowisku akademickim, Poznań 1986.

174. S. Pyszka: Kościół katolicki w obliczu sekt, w: Horyzonty wiary, 3/90, Kraków 1990.

175. J. B. Quandt: From the Small Town to the Great Community, New Brunswick, 1970.

176. R. Rak: Od utopii marksistowskich do mistycznych, Lublin 1993. 
177. J. Ratzinger: Kościół jako komunia, Krościenko 1993.

178. J. Ratzinger: Raport o wierze, w: Życie katolickie 12/85.

179. J. Ratzinger: List do biskupów kościoła katolickiego, Krościenko 1993.

180. A. Rodziński: Komunionistyczna wizja kultury, w: Człowiek społeczności, Niepokalanów 1988.

181. R. E. Rogowski: Światłość i tajemnica, Katowice 1986.

182. P. Rybicki: Struktura społecznego świata, Warszawa 1979.

183. P. Rybicki: Społeczeństwo miejskie, Warszawa 1972.

184. S. Rychliński: Ujęcie więzi społecznej w socjologii L. Krzywickiego, Warszawa 1938.

185. G. H. Sabine: A. History of Political Theory, London 1963.

186. H. Saint-Simon: Organizator, w: Pisma wybrane t. 2 Warszawa 1968.

187. J. Salij: Tajemnica Emmanuela dziasiaj, Poznań 1989.

188. M. Scheler: Istota i formy sympatii, Warszawa 1986.

189. H. Schelsky: Ist die Dauerreflektion der Religionssoziologie, Kolonia 1962.

190. H. Schmalenbach: Communion, a sociological category, Chicago 1977.

191. E. Sapir: Kultura, język, osobowość, Warszawa 1978.

192. H. Seweryniak: Dziś i jutro kościoła w Polsce, w: Przegląd powszechny 2/92.

193. T. Sikorski: Parafia, dziś,, w: Dziś i jutro parafii, Łódź 1991.

194. G. Simmel: Socjologia Warszawa 1975.

195. J. Słomińska: Mechanizmy i funkcje grup młodzieżowych, Warszawa 1986.

196. P. Smits: Schelsky's poging tot vernieuwing, w: Mens et Maat, 3/61.

197. A. Skowronek: Sekty, wyzwanie czy zgorszenie, Kraków 1992.

198. T. Sikorski: Słowo i metanoia, w: Być człowiekiem i chrześcijaninem (red. B. Bejze). Warszawa 1980.

199. P. Socha: Rozwój orientacji religijnej i światopoglądowej, Kraków 1992.

200. P. Socha: W poszukiwaniu istoty religijności, Psychologiczne badania związku religijności z autonomią, w: Nomos 1/92.

201. A. Sosnowski: Obserwacja uczestnicząca, osiągnięcia i perspektywy, w: Z metodyki i metodologii socjologicznych badań terenowych (red. K. Lutyńska). Warszawa 1985.

202. A. Sosnowski; J. Walkowiak: Przystosowanie młodzieży, a integracja społeczna, Szczecin 1987. 
203. A. Sosnowski: Rodzina a sąsiedztwo w osiedlowych społecznościach lokalnych, w: Morskie społeczności lokalne, teoria i empiria. Szczecin 1991.

204. A. Sosnowski: Rozwój Ruchu Oazowego wśród młodzieży osiedlowej. Szczecin 1988 (maszynopis powielany).

205. G. W. Stocking: Culture, and Evolution, New York 1968.

206. E. Staniek: Bogactwo Tajemnicy Kościoła, Kraków 1990.

207. A. L. Szafrański: Kairologia, Lublin 1990.

208. E. Sujak: Rozważania o ludzkim rozwoju, Kraków 1987.

209. J. Szacki: Historia myśli socjologicznej, Warszawa 1983.

210. J. Szacki: Ojczyzna, naród, rewolucja, Warszawa 1962.

211. Z. Stachowski: Kościół wobec nowych ruchów religijnych, w: Euhemer 4/91.

212. J. Szamocki: Wspólnota wspólnot, w: Wieczernik, 51/93, Poznań 1993.

213. S. Szczepaniec: Pytanie o posługi liturgiczne, Lublin 1989.

214. S. Szczepaniec: Pytanie charyzmat wspólnot odnowy, Lublin 1990.

215. J. Szczepański: Elementarne pojęcia socjologii, Warszawa 1970.

216. S. Szczepaniec: Posługi świeckich w Kościele, Lublin 1992.

217. J. Szczepański: Przystosowanie młodzieży do studiów wyższych, w: Kultura i społeczeństwo $1 / 62$.

218. J. Szmatka: Elementy mikrosocjologii, Kraków 1992.

219. J. Szmatka: Małe struktury społeczne, Warszawa 1989.

220. J. Szmatka: Jednostka i społeczeństwo, Warszawa 1980.

221. J. Sztumski: Społeczeństwo i wartości, Katowice 1992.

222. E. Szumańska: Wizja autentycznej wspólnoty, w: Kościół Polski na przełomie 2000 roku (red. T. Wołek), Warszawa 1987.

223. J. Sztumski: Społeczności lokalne jako przedmiot badań socjologicznych, w: Społeczności lokalnej regionu G. Sląska, Katowice 1987.

224. A. Śliwińska: Wychowawcze aspekty społeczności lokalnych, w: Socjologia wychowania t. IX, Toruń 1990.

225. W. Świątkiewicz: Miejskie społeczności lokalne G. Śląska, Katowice 1987.

226. G. Thils: Nowy wiek kościoła, w: Życie katolickie 5/85.

227. F. Toennies: Wspólnota i stowarzyszenie, Warszawa 1988.

228. A. Tarski: Pojęcie prawdy w językach nauk dedukcyjnych, Warszawa 1933. 
229. T. Tomaszewski: Wstęp do psychologii, Warszawa 1963.

230. R. Towler: The Need for Certainty, London 1984.

231. R. Turner: Collective Behavior, New York 1987.

232. J. Turowski: Socjologia, Lublin 1993.

233. K. Ujazdowski: Jak realizować wartości chrześcijańskie w życiu publicznym, w: Więź $4 / 92$.

234. J. Urteaga: Chrześcijanie do boju, Warszawa 1994.

235. J. Vanier: Wspólnota miejscem radości i przebaczenia, Warszawa 1991.

236. J. Wach: Socjologia religii, Warszawa 1961.

237. J. Wasilewski: Współczesna wersja podejścia elitystycznego, w: Współczesne tendencje w socjologii empirycznej, Kraków 1990.

238. Was ist Religionssoziologie, w: Probleme der Religionssoziologie, Kolonia 1962.

239. J. Warzeszak (red): Rozważania dla instytutów świeckich, Warszawa 1990.

240. J. Walkowiak: Przystosowanie młodzieży a integracja społeczna, Szczecin 1987.

241. P. Wejdland: Obrazy grup społecznych, Warszawa 1991.

242. K. Wojtyła: U podstaw odnowy, Kraków 1988.

243. K. Wojtyła: Osoba, podmiot i wspólnota, w: Roczniki Filozoficzne KUL, 24/1976.

244. J. Wołkowski: Dwa wektory odnowy, Warszawa 1966.

245. A. Wójtowicz: Przesłanki socjologicznych kategorii kultury religijnej, w: Studia Religioznawcze nr 19, Kraków 1984.

246. J. Wójcik: Od hipisów do szatanistów, Kraków 1992.

247. M. Weber: Wirtschaft und Gesellschaft, Tubingen 1956.

248. E. Weron: Powołanie i posłannictwo ludzi świeckich, Poznań 1989.

249. H. Wistuba: Wspólnota parafialna, Olsztyn 1984.

250. R. Woźniak: Rozwój i zmiana struktur społeczności miast portowych, w: Rozwój i zmiany w społecznościach ziem zachodnich i północnych Polski, Szczecin 1991.

251. R. Woźniak: Problemy struktur społecznych, a badania socjologiczne, w: Roczniki Koszalińskie 1982.

252. M. Yinger: Religia jako czynnik integracji społecznej, w: Socjologia religii, Kraków 1984.

253. M. Yinger: Religion, Society and the Individual, New York 1957.

254. F. Znaniecki: Nauki o kulturze, Warszawa 1971. 
255. A. Zuberbier: Słownik teologiczny, Warszawa 1988.

256. T. Żeleźnik: Człowiek w Kościele i świecie, w: Kościół - świat - świeccy, Warszawa 1988.

257. M. Żurowski: Współuczestnictwo kościelne, Kraków 1984.

258. K. Żygulski: Wspólnota śmiechu, Warszawa 1985.

259. T. Zysk: Jak badać przekonania religijne, w: Religia a życie codzienne, (red. I. Borowik), Kraków 1991 cz. II.

\section{Skala spójności wspólnoty}

Skala zawiera szereg twierdzeń - opinii dotyczących wspólnoty, życia ludzi i siebie samego. Zadaniem Twoim jest stwierdzenie, w jakim stopniu zgadzasz się lub nie zgadzasz z opinią zawartą w tych twierdzeniach. Przeczytaj każde twierdzenie oddzielnie, zwracając dokładnie uwagę na jego sens/ treść i odpowiedz w jakim stopniu zgadzasz się lub nie zgadzasz się $\mathrm{z}$ treścią $\mathrm{w}$ nim zawartą. Może ci się wydawać, że wiele twierdzeń jest podobnych. Nie ma jednak całkowicie takich samych. Odpowiedzi swoje będziesz wyrażał(a) liczbowo w skali od do 7:

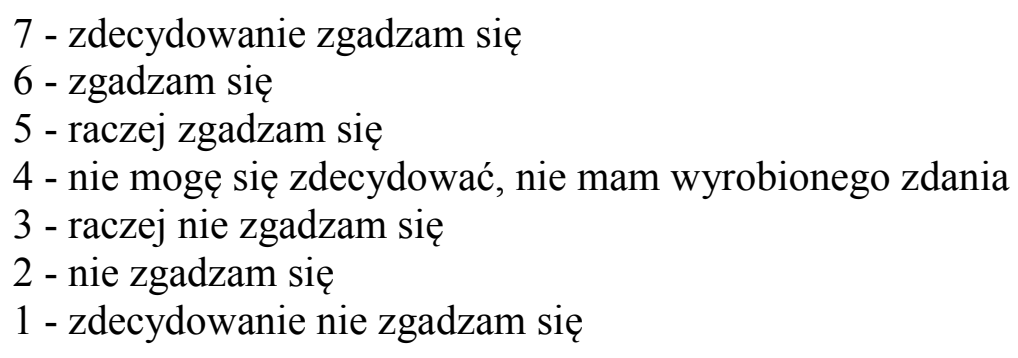

Na końcu każdego twierdzenia znajduje się miejsce na postawienie odpowiedniej cyfry.

1. Odpowiedzialność za drugiego człowieka jest zadaniem każdego z ludzi.

2. Istnieje wiele wzorców życia wspólnotowego.

3. Istnieje jeden wzorzec życia wspólnotowego.

4. Jakość wspólnoty zależy od poziomu wzajemnego zrozumienia wewnątrz niej.

5. Każdy człowiek odczuwa potrzebę bycia we wspólnocie.

6. Rodzina jest wspólnotą.

7. Sąsiedztwo w małych miastach i wioskach może tworzyć wspólnotę.

8. Osiedle mieszkaniowe tworzy wspólnotę.

9. Parafia jest wspólnotą.

10. Diecezja jest wspólnotą.

11. Kościół w Polsce jest wspólnotą.

12. Kościół powszechny jest wspólnotą.

13. Ruchy odnowy są wspólnotami. 
14. Ruch "Światło - Życie" jest wspólnotą.

15. Członkowie oazy w parafii są wspólnotą.

16. Małe grupy formacyjne są wspólnotami.

17. Klasa szkolna jest wspólnotą.

18. Grupa koleżeńska jest wspólnotą.

19. Wolność jest podstawą wspólnoty.

20. Miłość jest podstawą wspólnoty.

21. Wspólnotę przeżywamy zewnętrznie.

22. Wspólnotę przeżywamy wewnętrznie.

23. Jest możliwe utworzenie wspólnoty poprzez ustanowienie odpowiednich kar i nagród.

24. Jedynie we wspólnocie prawdziwe jest zdanie "Wszystko co posiadam jest Twoje."

25. Życie we wspólnocie umniejsza naszą osobistą godność i wolność.

26. Styl życia we wspólnocie pomaga wzrastać w wierze.

27. Człowiek nie może w pełni stać się osobą bez wspólnoty innych osób.

28. Wspólnota to przekonanie o wzajemnej odpowiedzialności.

29. Wspólnota to dążenie do tego samego celu.

30. Miłość nie wypływa z praktyki innych cech wspólnoty lecz wszystkie te cechy wypływają z miłości.

31. Czy jest możliwe osamotnienie we wspólnocie?

32. Fizyczne oddalenie się od wspólnoty jest okresowo konieczne. 33. Wspólnota to troska o drugiego człowieka.

34. Wspólnota to dzielenie się z drugim człowiekiem tym co posiadamy.

35. Wspólnota to znoszenie ciężarów drugiego człowieka.

36. Wspólnota to umiejętność kochania drugiego człowieka.

37. Tolerancja i przebaczenie to cechy wspólnoty.

38. Uznanie /akceptacja/ drugiego człowieka to cecha wspólnoty.

39. Wspólnota to uległość wobec drugiego człowieka.

40. Członek wspólnoty powinien zaznaczyć swój własny wkład w tą wspólnotę.

41. Posłuszeństwo i consensus to cechy życia we wspólnocie

42. Członek wspólnoty powinien pozostawać w jej cieniu.

43. Wspólnoty to służba drugiemu człowiekowi.

44. Wspólnota powinna być nie tylko zwarta ale i otwarta.

45. Bez służby wewnątrz wspólnoty nie ma powodzenia służby ad extra.

46. Więź społeczna we wspólnocie zbudowana jest na zasadzie sieci. 
47. Więź społeczna we wspólnocie jest zbudowana na zasadzie łańcucha.

48. Struktury są konieczne do funkcjonowania wspólnoty.

49. Podstawą budowania struktur wspólnoty jest jasno określona hierarchia wartości i celów.

50. Struktury we wspólnocie powinny być elastyczne i zmienne.

51. Spotkania we wspólnocie to ważny czynnik jej budowania i umacniania.

Praktyki wspólnoty religijnej i świeckiej (zakreśl odpowiednia cyfre).

A. Małe grupy formacyjne odbywają spotkania:

1. Codziennie

2. Prawie codziennie

3. Parę razy w miesiącu

4. Rzadziej

5. Nie ma tych spotkań

B. Spotkania całej wspólnoty:

1. Prawie codziennie

2. Raz na tydzień

3. Raz na miesiąc

4. Parę razy w roku

5. Nie odbywają się

\section{Oaza dla mnie to:}

1. Małe grupy formacyjne

2. Wspólnota parafialna

3. Wspólnota ogólnopolska Ruchu

4. Zielone miejsca na pustyni

5. Czasopismo Ruchu

D. Należę do wspólnoty glównie z:

1. Przyjaźni i obowiązku wobec Boga

2. Wewnętrznej potrzeby

3. Przyzwyczajenie

4. Ze względu na otoczenie

5. Dla rozrywki i zabicia nudy

6. Z innych powodów (podaj jakich)

E. Bycie we wspólnocie ma dla mojego życia znaczenie:

1. Zdecydowanie duże

2. Duże

3. Przeciętne

4. Małe

5. Żadne 
F. Ze spotkań ogólnowspólnotowych najbardziej cenię:

1. Informacyjne

2. Modlitewne

3. Nabożeństwo KWC

4. Liturgiczne

5. Naukę śpiewu

G. Co jest przyczyną odchodzenia ludzi ze wspólnoty:

1. Postawa księży opiekunów

2. Postawa animatorów

3. Postawa uczestników

4. Sytuacja polityczna w Polsce

5. Inne (podaj jakie)

H. Jakie mam propozycje odnośnie nowych form spotkań w naszej wspólnocie

( Received 10 December 2013; accepted 31 January 2014 ) 